\title{
INTERVENCIÓN OBLIGADA DE TERCEROS
}

\section{LA INTERVENCION OBLIGADA GENERICA}

\author{
TESIS DOCTORAL
}

DE

ADOLFO ARMANDO RIVAS

DIRECTOR DE TESIS:

DOCTOR ROBERTO OMAR BERIZONCE 
PRINCIPALES ABREVIATURAS

ED.

El Derecho

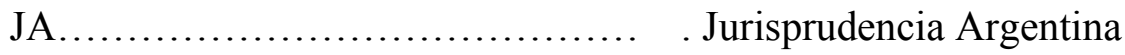

LL ............................... La Ley

Cam................................. Cámara

CF....................................émara Federal

CN.................................. Cámara Nacional

CS................................ Corte Suprema de Justicia

Civ................................... Civil

Civ.y Com.............................. Civil y Comercial

CPCCN ................................ Código Procesal Civil y Comercial de la

Nación

CCCN................................ Código Civil y Comercial de la Nación

CPrC .................................édigo de Procedimientos Civil

CPC .............................. Código Procesal Civil

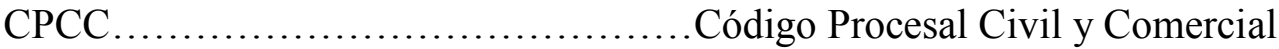

DT $\ldots \ldots \ldots \ldots \ldots \ldots \ldots \ldots \ldots \ldots \ldots \ldots \ldots \ldots \ldots$ Digesto del Trabajo

SCJ ............................... Suprema Corte de Justicia. 


\section{INDICE}

\section{PRESENTACIÓN DE TESIS}

Copia de informe del Director de tesis.

Resumen de contenido contenido.........................................18

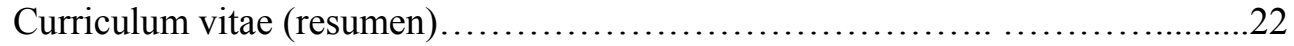

TESIS

CAPITULO PRIMERO

TEMATICAS PRELIMINARES

SECCION PRIMERA

LA ACCION DE GARANTIA

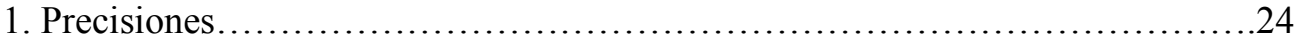

2. La acción de garantía. Derecho extranjero................................27

3. La acción de garantía. Derecho argentino....................................34

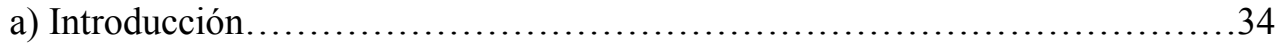

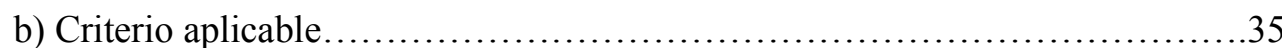

c) La ley general del ambiente............................................ 37

4. Pretensiones declarativas y sentencias monitorias.............................38

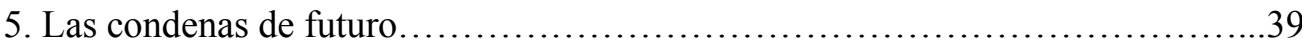

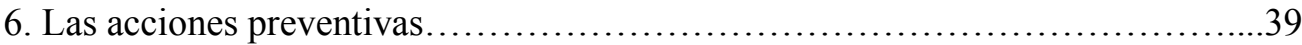

SECCION SEGUNDA

APROXIMACION A LA INTERVENCION TERCERISTA

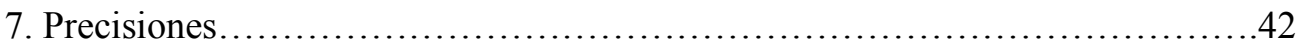

8. La adhesión................................................................ 42

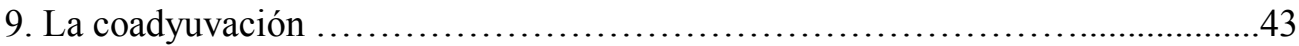




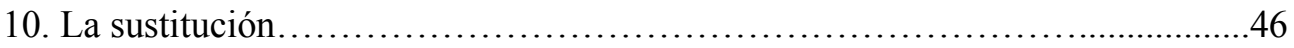

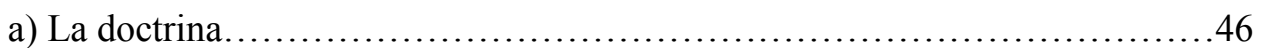

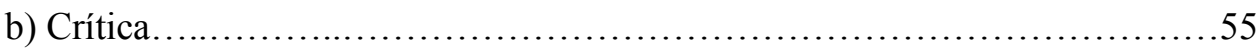

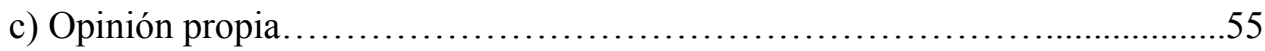

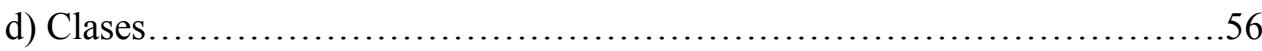

11. Coadyuvación y sustitución...........................................60

12. Tipos de intervención voluntaria........................................6 61

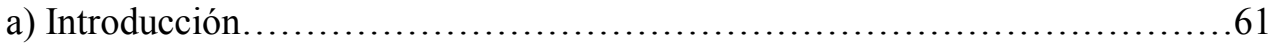

b) Intervención voluntaria calificada o litisconsorcial.........................62

c) Intervención voluntaria no calificada genérica............................ 63

d) Intervención voluntaria no calificada por derivación subrogatoria.............65

e) Intervención no calificada por adquisición del objeto litigioso.................65

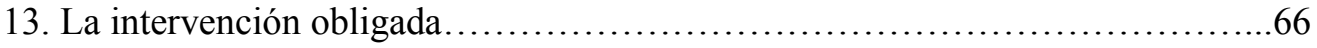

\section{CAPITULO SEGUNDO}

LA INTERVENCION OBLIGADA DE TERCEROS

SECCION PRIMERA

APROXIMACION A LA INTERVENCION OBLIGADA

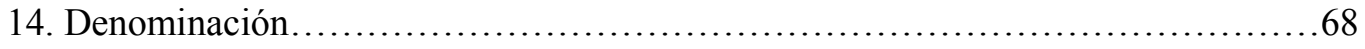

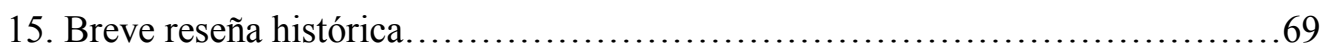

SECCION SEGUNDA

DERECHO EUROPEO

16. Noticia introductoria.................................................... 71

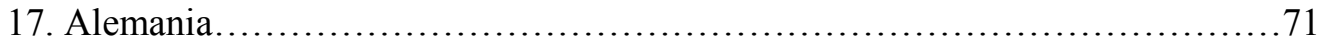

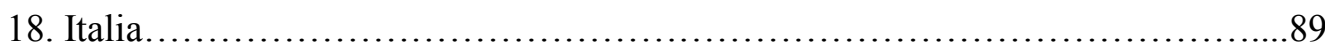


a) La codificación anterior................................................. 89

b) El código vigente....................................................96

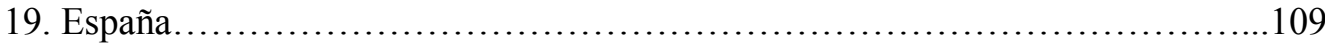

SECCION TERCERA

DERECHO SUDAMERICANO

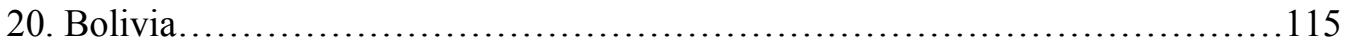

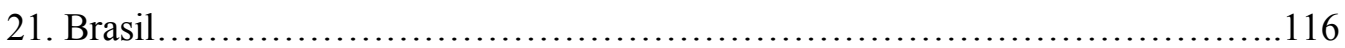

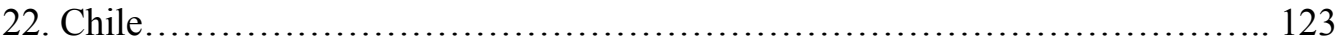

23. Colombia.............................................................. 126

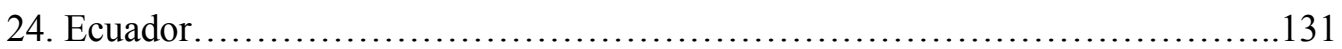

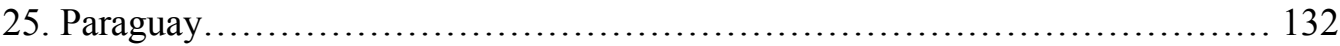

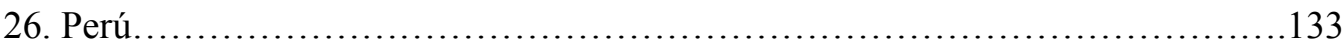

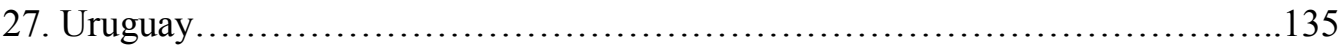

28. Venezuela................................................................. 138

\section{CAPITULO TERCERO}

\section{LA INTERVENCION OBLIGADA DERECHO ARGENTINO}

SECCION PRIMERA

ANTECEDENTES

29. La doctrina ............................................................... 141

30. La jurisprudencia .................................................... 150

31. Proyectos de codificación nacional..........................................151

32. Antecedentes provinciales................................................ 161

33. Fuentes del CPCCN $\quad$...................................................... 168

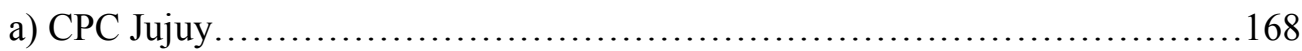


b) CPC La Rioja ......................................................... 170

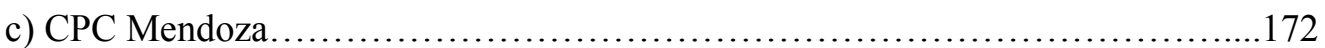

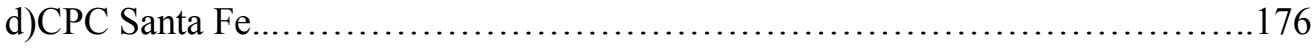

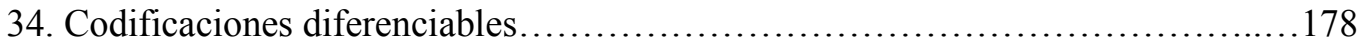

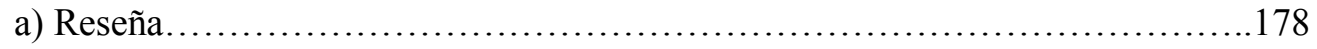

b)Tierra del Fuego....................................................... 178

SECCION SEGUNDA

CONCEPTO. CLASES. DIFERENCIACIONES

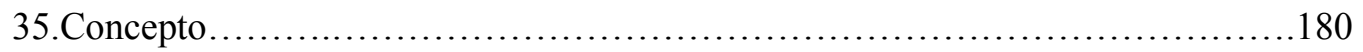

36.Intervención obligada y litisconsorcio necesario...............................181

37.Clases de intervención obligada............................................183

38.Intervención obligada por aseguramiento .................................186

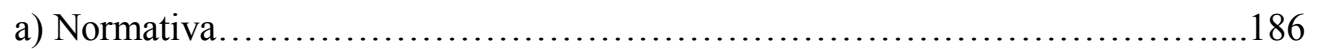

b)Relación demandado con asegurador propio............................... 187

c)Relación damnificado con asegurador propio..............................188

d)Relación damnificado con asegurador del responsable.......................189

e)La dirección del proceso.............................................. 189

39. La evicción......................................................................

a) La evicción.Instituto sustancial.............................................191

b) Alcance.Evicción y saneamiento........................................ 194

c) El Código Civil y Comercial de la Nación........................................196

d)La evicción. Instituto procesal..........................................198 


\section{CAPITULO CUARTO}

INTERVENCION OBLIGADA GENÉRICA

SECCION PRIMERA

\section{ALCANCE DE LA INTERVENCION OBLIGADA GENÉRICA}

40..Objetivos altruistas, ordenatorios e instructorios .201

41.Campo de aplicación según la Exposición de Motivos. 205

a) Introducción..............................................................205

b) La acción regresiva.................................................205

c) La conexidad ......................................................205

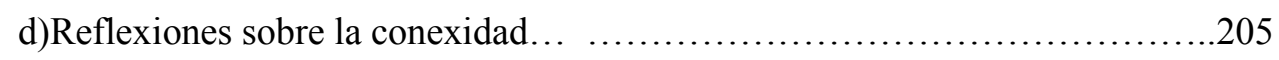

42.Casos de aplicación según la doctrina.................................206

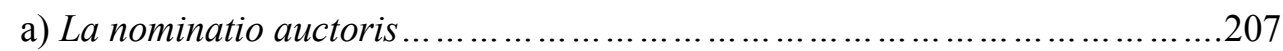

b) El tercero pretendiente........................................... 211

c ) La extensión de la cosa juzgada..................................... 212

d) Conclusión................................................................214

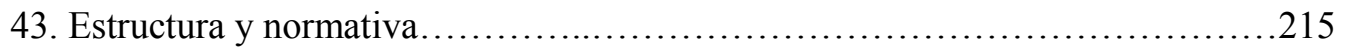

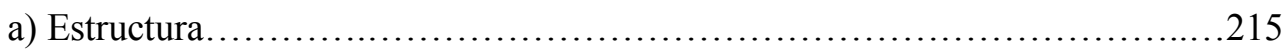

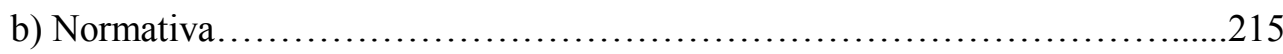

\section{SECCION SEGUNDA}

\section{LA DENUNCIA DE LITIS}

44. La citación. Precisiones terminológicas......................................217

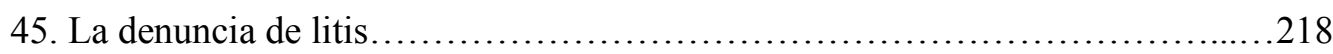

46. Naturaleza de la denuncia de litis.........................................219 
a)Teoría del anuncio con extensión de la cosa juzgada.

b) Teoría del valor declarativo de la llamada en causa como demanda.

47. Opinión propia. .222

48. Iniciativa de la denuncia de litis .225

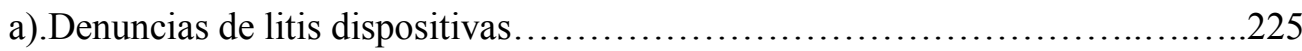

b).Citación obligada judicial............................................. 226

49 ¿Disponibilidad del derecho o carga de denunciar?..............................226

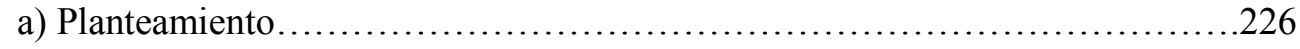

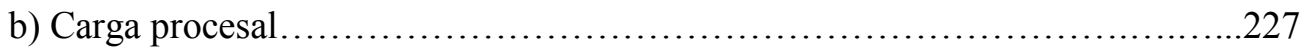

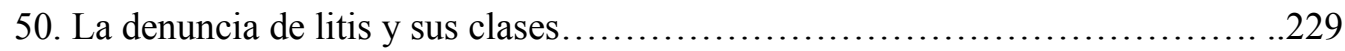

51. Denuncias de litis regresivas. Concepto y clasificación.................... 230

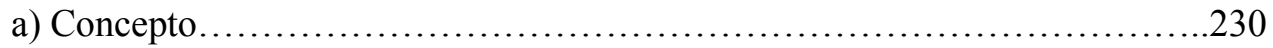

b) Clasificación..................................................... 231

52. Ejemplificación..........................................................231

a) Denuncias de litis regresivas por responsabilidad cuasidelictual............ 232

b) Denuncias de litis regresivas por responsabilidad contractual.............. 232

c) Denuncias de litis regresivas por responsabilidad derivada $\quad \ldots \ldots \ldots \ldots \ldots . . . \ldots 234$

d) Denuncias de litis regresivas por contribución............................. 235

53. Notificaciones de apariencia litisconsorcial regresiva..........................236

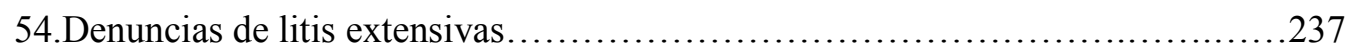

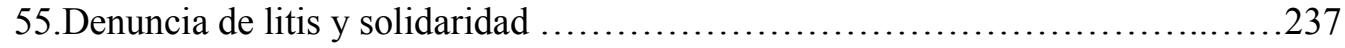

56. Denuncia de litis excluyente. Concepto...................................240

57. Citaciones de apariencia litisconsorcial excluyente....................... 242

a) Citaciones por consignación...............................................244 
b) Citaciones en la realización de bienes

58. Citación de sub inquilinos y otros ocupantes.

\section{SECCION TERCERA}

\section{PRESUPUESTOS DE LA DENUNCIA DE LITIS}

59. Enunciación. .248

60. Interés 249

61. Legitimación para denunciar 251

a) Partes originarias .251

b) Denuncias de litis regresivas. 253

c) Denuncias de litis extensivas. 254

d) Denuncias de litis excluyentes. 254

62. Denuncia de litis por terceros. .255

a) Denuncias de litis regresivas por responsabilidad en general...................255

b) Denuncias de litis regresivas por contribución ...................................258

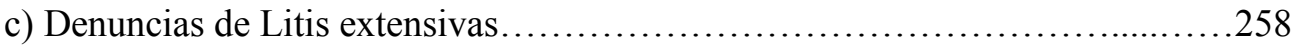

d)Denuncias de litis excluyentes..........................................258

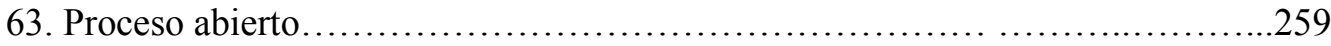

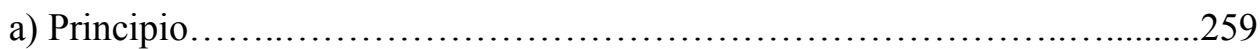

b) Prueba anticipada....................................................... 259

c) Diligencias preparatorias........................................... 260

d) Mediación.... ............................................................ 261

64. Tipos de procesos y pretensiones.... .................................... 262

a) Denuncias de litis regresivas. Procesos de conocimiento........................ 262

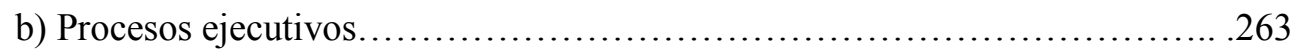




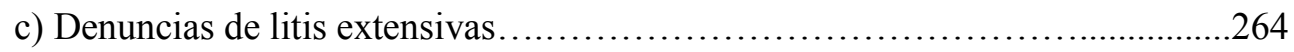

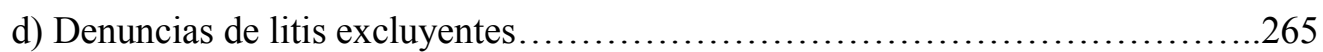

65. La intervención obligada y los procesos colectivos...........................265

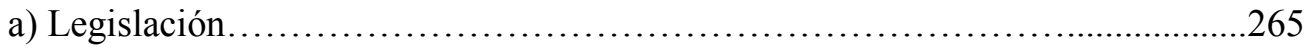

b) Procedimientos colectivos de creación pretoriana............................267

c) La Corte Suprema en instancia originaria................................. 267

66. Inexistencia de presupuestos............................................. 270

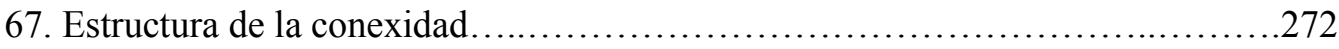

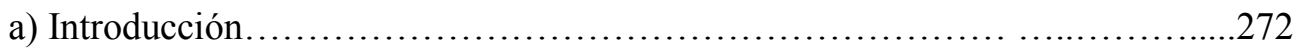

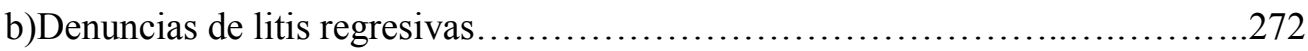

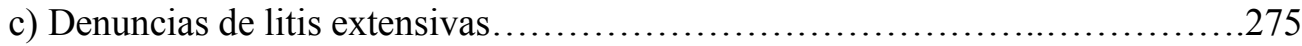

d) Denuncias de litis excluyentes...............................................275

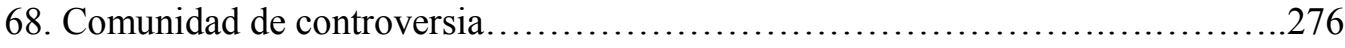

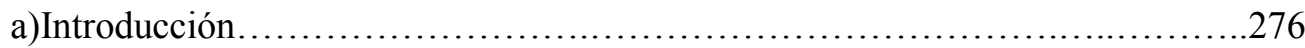

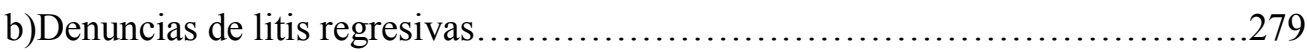

c)Denuncias de litis extensivas.................................................... 280

d)Denuncias de litis excluyentes.............................................280

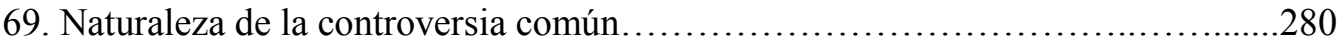

\section{CAPITULO QUINTO}

\section{LA DENUNCIA DE LITIS Y EL PROCESO}

SECCION PRIMERA

PROCEDIMIENTO DE DENUNCIA

70. Normativa. 


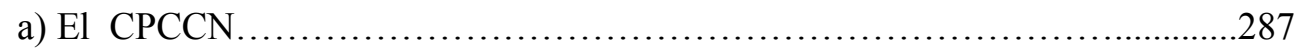

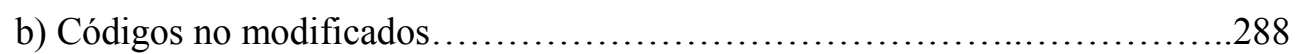

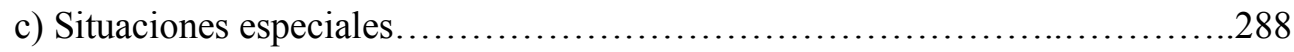

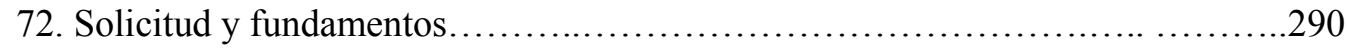

73. Inadmisibilidad y sustanciación.............................................291

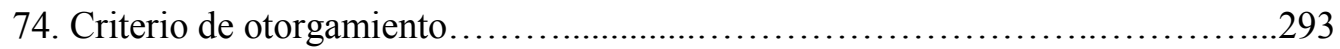

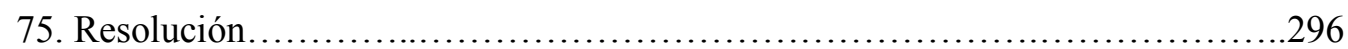

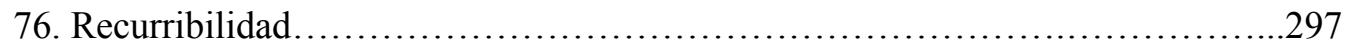

SECCION SEGUNDA

EFECTOS SOBRE EL PROCESO

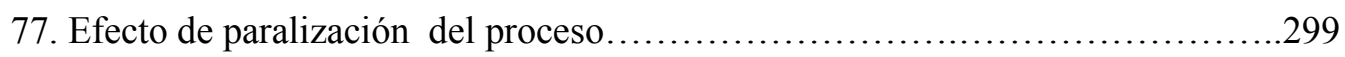

78. Plazos de paralización.................................................. 302

a) Plazo de convocatoria...........................................................

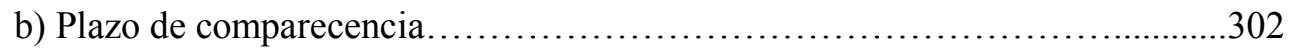

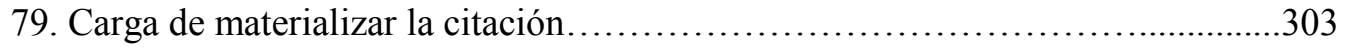

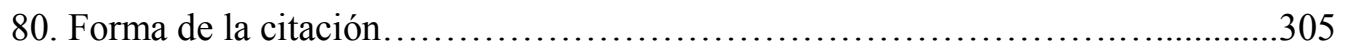

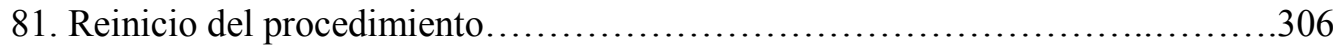

a) Reiniciación normal...........................................................306

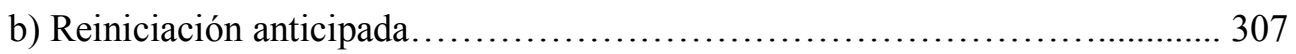

\section{CAPITULO SEXTO}

\section{LA DENUNCIA DE LITIS Y LOS SUJETOS}

SECCION PRIMERA

EFECTOS DE LA NOTIFICACIÓN DE LA DENUNCIA

82. Efecto sobre la calidad originaria. 
83. Efectos sobre el tercero................................................. 308

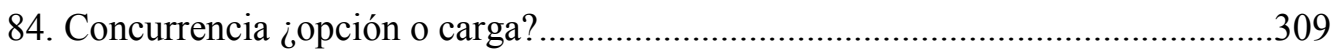

85. El ingreso tardío....................................................... 311

86. Efecto extensivo de la cosa juzgada.................................... 312

a) Introducción....................................................... 312

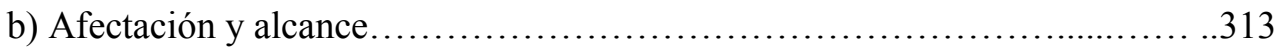

c) Denuncias de litis regresivas....................................... 314

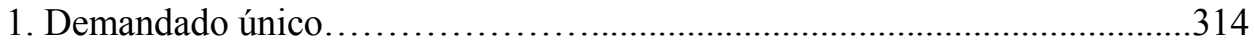

2. Pluralidad de demandados............................................ 315

3. Determinación indirecta de responsabilidades...........................316

d) Denuncias de litis extensivas............................................. 317

e) Denuncias de litis excluyentes............................................317

87.Cosa juzgada y responsabilidades reflejas................................. 317

\section{SECCION SEGUNDA}

\section{LA ABSTENCION DEL TERCERO}

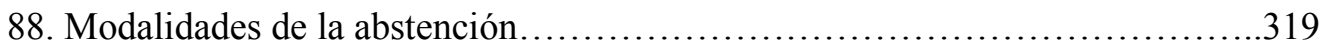

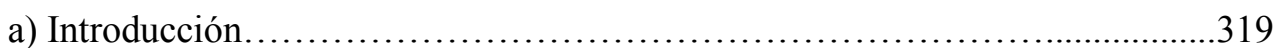

b) Cuestionamiento incidental........................................... 319

89. Significado y consecuencias de la abstención..................................322

a) Significado de la abstención...................................................322

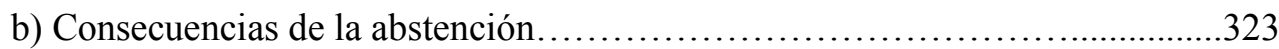

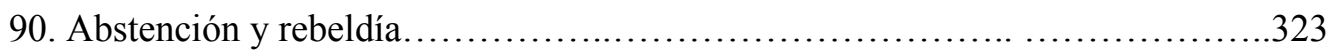

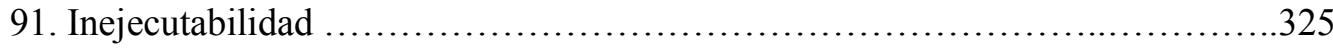


CONCURRENCIA DEL CITADO

92. Modalidades de concurrencia................................................ 326

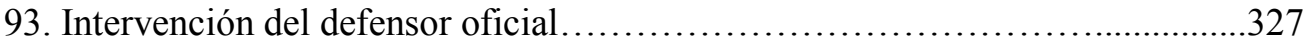

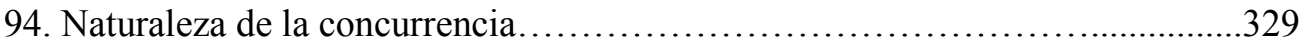

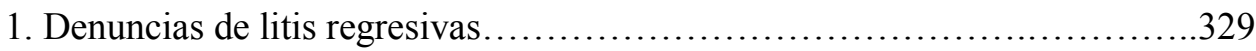

2. Denuncias de litis extensivas...................................... 335

3. Denuncias de litis excluyentes........................................335

95. Función coadyuvante ....................................................

96. Contenido sustancial del responde...................................... 336

a) Denuncia de litis regresiva....................................... 336

b)Denuncias de litis extensivas........................................337

c)Denuncia de litis excluyente......................................... 337

97. Actuación procesal.................................................. 338

a) Contestación de demanda............................................. 338

b) Reconocimientos....................................................... 338

c) Excepciones............................................................ 339

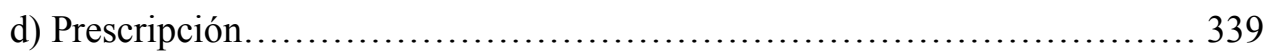

e) Medios anormales de terminación del proceso.......................... 340

f) Prueba.1. Relación tercero-contraparte................................. 340

2. Relación tercero-denunciante................................342

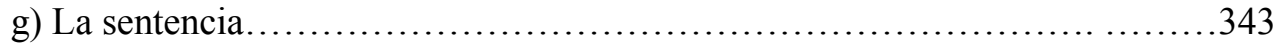

h) Recursos.......................................................... 343

SECCION CUARTA

EFECTOS SOBRE EL CONCURRENTE 
98. Tipo de efectos

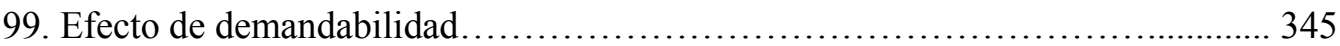

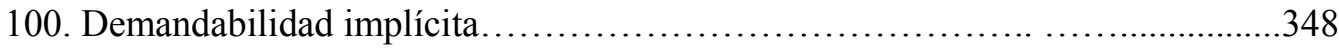

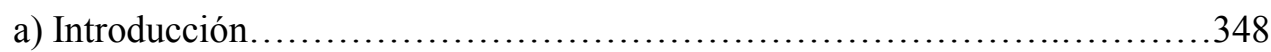

b) Demandabilidad expresa.................................................348

c) Demandabilidad implícita.................................................350

d) Evolución de la Corte Suprema........................................351

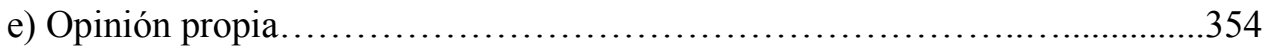

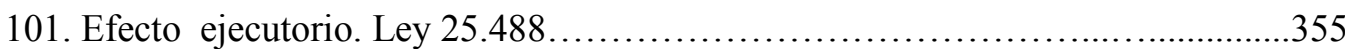

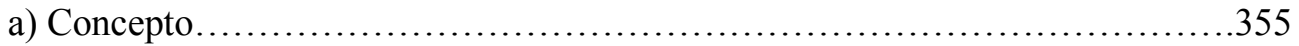

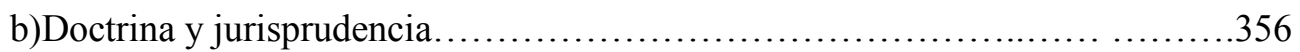

102.Significado de la tercera parte del art.96 CPCCN.......................... 359

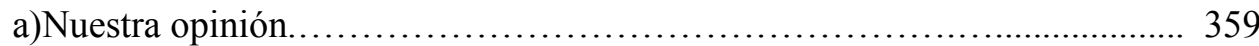

b) La acción de garantía y la solución del CPCCN.......................... 366

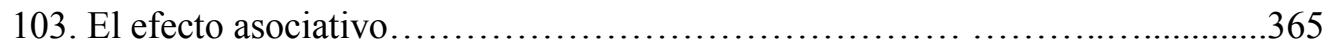

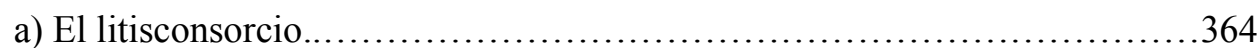

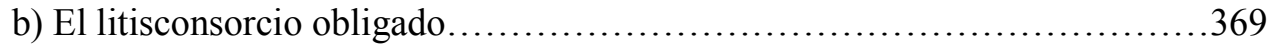

c) Denuncias de litis regresivas y extensivas.................................370

d)Denuncias de litis excluyentes....................................370

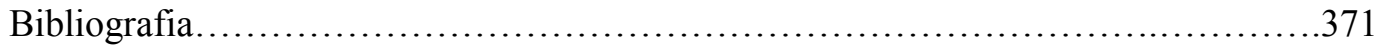




\section{PRESENTACION DE TESIS}

\section{Reproducción de Informe del Director de tesis}

OPof. QDr. Raberto O. OBerizance

Profesor Emérito UNLP

La Plata,6 de abril de 2015

A la Señora Secretaria de Post grado, Prof. Valeria Huenchiman

En cumplimiento de lo dispuesto por el art. 54 de la Ordenanza 261 y en mi condición de director de tesis del doctorando Adolfo Armando Rivas, vengo a presentar el informe correspondiente a la tesis elaborada por el nombrado, titulada "INTERVENCION OBLIGADA DE TERCEROS. LA INTERVENCIÓN OBLIGADA GENÉRICA”.

El autor considera de manera previa a tal estudio distintas figuras procesales asentando conocimientos que luego utilizará para fundar las posiciones que asume frente al instituto de la intervención obligada de terceros. Así, analiza los conceptos de adhesión, coadyuvación -aporta al respecto una novedosas distinción entre la coadyuvación propia y la 
impropia- y sustitución -con respecto a la que trae su singular visión-, al igual que con relación a la acción subrogatoria y su recepción por la normativa procesal.

Ya con respecto a intervención obligada de terceros en sí misma, el doctorando relata con precisión las opiniones que al respecto muestra la más importante doctrina alemana, italiana y española e incursiona en la sudamericana, todo con transcripción actualizada del derecho positivo en la que se basa. También hace lo propio con la doctrina nacional, los proyectos nacionales y provinciales referidos al tema, sin olvidar la correlación entre la legislación procesal nacional y la de las provincias ni dejar de hacer un preciso análisis de los códigos que sirvieron de fuente al Procesal Civil y Comercial de la Nación Argentina.

Una vez que el autor pasa a encarar la intervención obligada tal como aparece en el código procesal nacional, emplea una metodología también novedosa, como lo es separar fundadamente el instituto en intervención obligada por aseguramiento, intervención obligada por evicción e intervención obligada genérica a la que considera encarnada en los arts.96 (94) a 96(98) del CPCCN y que se constituye en el verdadero objeto de la tesis, sin perjuicio de incursionar someramente en las dos primeras modalidades.

Considera entonces, de manera minuciosa todos los objetos componentes del instituto referido, describiendo adecuadamente su conformación y objetivos. Separa en ellos, en función de la distinción que práctica, realmente novedosa, los que hacen a la clasificación que elabora entre denuncias de litis regresivas, extensivas y excluyentes. A la luz de esa metodología, analiza el concepto de "controversia común" y el de extensión de la cosa juzgada, así como también da su propia y original 
opinión acerca del sentido y alcance de la posibilidad ejecutoria planteada por la tercera parte del art. 96(98) del CPCCN.

En tal desarrollo afronta las distintas problemáticas abarcadas por la doctrina y fija al respecto su posición -no vacila en afirmarla aun frente a caracterizada doctrina extranjera-, en muchos casos mediante aportes novedosos y siempre tratando de profundizar en los temas correspondientes, de modo tal que puede afirmarse que el trabajo configura una serie de tesis encadenadas que confluyen en una final y globalizadora, como lo es otorgar a la intervención obligada genérica naturaleza sui generis en función de un tercero que opera como un coadyuvante por coordinación concepto que vincula con el de coadyuvación propia-, diferenciable de la coadyuvación simple y a la vez de la que sostiene que de manera impropia puede generar la intervención litisconsorcial.

Cumpliendo en definitiva con los extremos referidos por el art.54 de la Ordenanza 261, manifiesto mi opinión en el sentido de que por la profundidad de sus conceptos, la novedad de su contenido y la importancia teórico-práctica de un trabajo que aborda una temática no muy transitada por la doctrina, la tesis referida por este informe alcanza acabadamente con los parámetros necesarios para ser admitida y en su momento aprobada.

\section{Dr. Roberto Omar Berizonce}




\section{Resumen de Contenido.}

Para la formulación de nuestra tesis partimos de la necesidad de determinar el campo abarcado por la intervención obligada de terceros de derecho procesal en su aspecto genérico, instituto que elegimos como objeto de nuestro estudio. Establecemos al efecto y en primer lugar, un límite geográfico ya que solamente consideramos en el derecho comparado extranjero las doctrinas y legislación de Alemania, Italia y España, así como la sudamericana; en el derecho argentino los antecedentes nacionales y los proyectos y normativas de todas las provincias en su correspondencia con las normas de derecho sustancial, incluyendo las del CCCN de próxima vigencia.

El segundo límite resulta de separar -teniendo en cuenta la existencia de elementos diferenciadores- las distintas figuras que conforman la intervención obligada de terceros para así poder centrar nuestro estudio en una de ellas-la intervención obligada referida. De tal manera, sostenemos que, no obstante su raíz común y la existencia de verdaderos vasos comunicantes, es posible considerar una intervención obligada de terceros de carácter genérico, esquematizada por un sistema que en el orden nacional integran los arts.96(94) a 98(96) CPCCN; junto a ella la intervención obligada por evicción (regulada en el Cód.Civil y el CCCN y en los arts.107(105) a 112(110) CPCCN) y la intervención obligada por aseguramiento (ley 17.458). De las tres, como lo señalamos, elegimos la primera $\mathrm{y}$ en torno a ella trabajamos nuestra tesis. Sin embargo, no podemos evitar una esquemática incursión en las otras dos, respecto a las que hacemos diversas consideraciones desde un enfoque procesalista, 
algunas de las cuales consideramos novedosas como las referentes al carácter sustitutivo o no de la actuación del garante de evicción.

Buscando ceñir aun más la delimitación de nuestro objeto de análisis, nos encontramos con ciertos casos que la doctrina y la jurisprudencia suelen incluir en la intervención obligada, inclusión que a nuestro juicio afecta su recta comprensión por confundir los elementos componentes de aquélla, con instrumentos de comunicación o citaciones destinados a objetivos diversos ajenos a dicha forma de tercería. Nos referimos así, a las citaciones típicas de los juicios ejecutivos, a los mecanismos de los juicios de consignación, a las citaciones previstas en la normativa civil con referencia a ciertos contra tos (locaciones, usufructo).

En las condiciones descriptas, advertimos que no podemos hacer un tratamiento global de la intervención obligada y mucho menos de la genérica, sino que es preciso descomponerla en sus componentes y estudiarlos por separado aun cuando ello no significa considerarlos aisladamente sino con perspectiva de conjunto. Nos encontramos así con el requerimiento de citación al tercero, instrumento del interés de la parte que lo solicita para aprovechar un mecanismo que el orden jurídico establece para la armónica solución de los conflictos. Dicho instrumento no es sino la denuncia de litis que una vez efectivizada mediante la correspondiente y formal citación judicial al tercero, produce el efecto fundamental buscado por el denunciante, es decir la extensión de la cosa juzgada sobre aquel sujeto, concurra o no al juicio. De ahí que corresponda tener en cuenta un especial componente, como lo es el derecho del tercero a participar o no del proceso, derecho a la vez vinculado con los efectos que la denuncia tiene sobre el juicio al generar su paralización. 
Precisamente aquella participación sirve para diseñar un límite subjetivo a la intervención obligada de terceros, pues dejan de serlo para convertirse en parte equiparable a las tempestivamente originarias, quienes al incorporarse al juicio, pasan a ser demandantes o demandadas. Ello nos permite afirmar que solamente serán terceros los que intervengan materialmente en el juicio sin asumir aquellas posiciones y quienes, adecuadamente citados, se abstengan de concurrir al juicio, pero, al igual que aquellos, queden sujetos al efecto extensivo de la cosa juzgada.

Temas de singular importancia son los de la naturaleza jurídica y clasificación de la denuncia de litis; frente al mismo, sostenemos que la concepción de Calamandrei basada en la acumulación de litis y el llamamiento en causa, no puede tener andamiento en el sistema del CPCCN, asentado en la idea germánica de la denuncia como aviso al tercero generador de consecuencias jurídicas de pleno derecho, fundamentalmente, la extensión de la cosa juzgada. Precisamente, sostenemos que en nuestro sistema, no se acumula la litis del denunciante contra el tercero sino que por el mecanismo legal al que antes nos refiriéramos, el tercero es avisado de la existencia de una litis a la que, pese a ser ajeno quedará incorporado, con miras a la extensión de la cosa juzgada a un litigio futuro entre dichos su jetos.

Buceando en la exposición de motivos que precede al proyecto del que se consagraría como $\mathrm{CPCCN}$, nos apartamos de la clásica identificación de los casos de intervención obligada (acciones de regreso, nominatio auctoris, citaciónes del colegitimado y del tercero pretendiente), para reemplazarla por otra que elaboramos en base a los objetivos inmediatos de la denuncia, a saber: regresivas (cuando apuntan a preservar una acción de regreso contra el tercero),extensivas (si solo quieren extender la cosa 
juzgada sobre el tercero para preservar al denunciante de sus futuros reclamos indemnizatorios) y excluyentes (cuando buscan asegurar al denunciante frente a reclamos reivindicatorios del tercero con respecto al derecho discutido).

La denuncia de litis, componente fundamental, verdadero pivote de la intervención obligada, impone para su viabilidad, de la existencia de ciertos presupuestos (proceso abierto, pretensión adecuada, legitimación denunciante),entre los que resulta fundamental la comunidad de controversia, presupuesto que entendemos no es exacto equivalente a la comunidad de causa del derecho italiano.

Nos ocupamos de desarrollar un tema, no muy frecuentado por la doctrina, como es el referente a las distintas maneras en la se produce la extensión de la cosa juzgada sobre el tercero, según el tipo de denuncia de litis producida.

Estudiamos también, ya con referencia temáticas muy propias del sistema argentino, los fenómenos que denominamos de demandabilidad implícita por oposición a la demandabilidad expresa, concepto aquél de elaboración pretoriana. Igualmente, hacemos una interpretación propia de la polémica tercera y última parte del art.98(96) CPCCN referente a la ejecutabilidad de la sentencia contra el tercero, sosteniendo que posibilita, sin convertirse en una acción de garantía similar a la italiana, que en determinadas situaciones, el litisdenunciante pueda repetir de aquel sujeto

En definitiva creemos haber demostrado que la intervención obligada genérica, conforma una figura sui generis y por tanto no confundible con las intervenciones voluntarias y necesarias, si bien nuestro esfuerzo apunta fundamentalmente a diferenciarlo de las primeras a las que en general doctrina y jurisprudencia apuntan a identificar. Para ello le asignamos una 
función de apoyatura de alguna de las partes originarias, pero partiendo de la existencia de distintas maneras o modalidades de coadyuvación que permiten -y a la vez le imponen-una participación diferenciada.

Adolfo A.Rivas

\section{Curriculum resumido}

Ex magistrado provincial y federal.

Ex titular regular de Derecho Procesal en la Facultad de Ciencias Jurídicas de la Universidad Nacional de Buenos Aires.

Actual profesor emérito en curso de post grado en la Facultad de Ciencias Jurídicas de la Universidad del Salvador.

Autor de diversos libros (El amparo, Teoría general del proceso, Tratado de los recursos ordinarios y el procedimiento en segunda instancia, Tratado de las tercerías, Medidas cautelares). Cursos y conferencias en distintas universidades del país y el exterior. Más de un centenar de trabajos en publicaciones del país y el extranjero. 
TESIS

INTERVENCION OBLIGADA DE TERCEROS

LA INTERVENCION OBLIGADA GENERICA

ADOLFO ARMANDO RIVAS 


\title{
CAPITULO PRIMERO
}

\section{TEMATICAS PRELIMINARES}

\author{
SECCION PRIMERA
}

LA ACCION DE GARANTIA

\section{Precisiones}

El proceso está pensado como un medio de canalizar un enfrentamiento entre un actor que sustenta su pretensión y el demandado que se opone al triunfo de la misma. Se trata de roles de imprescindible presencia en la estructura de un litigio, dada la función procesal que a cada uno corresponde. El primero podrá allegarse de manera voluntaria planteando su pretensión, pero también puede ocurrir que lo haga coactivamente -bajo apercibimiento de rebeldía-en el litisconsorcio necesario. El demandado, en cambio, bajo el mismo apecibimiento, siempre está forzado a asistir.

Cada uno de ellos ,tendrá un campo propio de actuación en el que puede admitirse la presencia de otros sujetos si se configurara un litisconsorcio.

Tales papeles no tienen una correspondencia total con el orden cronológico de llegada al juicio, salvo en el caso del actor en el que debe coincidir necesariamente con el primer arribo. El demandado, en tanto, podría no ser el segundo si un sujeto distinto se apersona en el juicio antes de su llegada. 
Precisamente, el esquema básico y sencillo que hemos señalado puede complicarse con el arribo al pleito de nuevos sujetos, sea en el campo actor sea en el espacio demandado, para discutir la pretensión en debate o alguna que pudiera conectársele, conforme el interés que ostenten al efecto y la legitimación que se les reconozca. Se trataría de la llegada del denominado tercero (tertius) figura que impone considerarla desde los puntos de vista cronológico y funcional respectivamente.

Los terceros cronológicos pueden compartir el primer lugar ${ }^{1}$; $\operatorname{arribar}$ segundos antes de que lo haga el demandado, ingresar en cuarto lugar y aun después. Tal lo que resulta de los arts 92(90) y 96(94) CPCCN. Sin embargo, se puede llegar tercero en tiempo y no serlo por la naturaleza de su desempeño ya que el momento en que se ingresa no define la calidad procesal con la que se lo hace: así, un tercero cronológico podrá presentarse como demandante o demandado en virtud de su pertenencia a la relación sustancial debatida en el proceso; tal la situación del denominado interviniente litisconsorcial, es decir quien pudo demandar o ser demandado-cosa que indica aquella, al punto que en su actuación ulterior se lo equipara a la parte principal ${ }^{2}$.El litisconsorte necesario, nunca será tercero, no obstante poder ingresar cronológicamente como tal ,ya que su lugar se encuentra reservado para ser ocupado como condición para que el fallo a dictarse pueda tener valor. El tercerista excluyente, al igual que el de dominio o el de mejor derecho, en defensa de su derecho sustancial, aporta

\footnotetext{
${ }^{1}$ Destacamos que algunos códigos procesales (CPC Jujuy,art.90;CPC Mendoza,art.25 y CPCC Santa Fe,art.309 en materia de evicción) permiten que el garantizado cite al garante para la preparación de la demanda

2.Arts 92(90) inc.2 y 93( 91) segunda parte CPCCN.

2.Es el caso de los arts.90 inc. 2 y 91 segunda parte CPCCN
} 
para incorporar pretensiones diversas a la discutida y no para integrarse subjetivamente en ésta.

Ante tal imprecisión corresponde recurrir al criterio funcional pensando en qué roles puede cumplir un sujeto y en qué medida serán distinguibles.Solamente de ese modo podremos sostener que quienes están en el proceso en defensa de un derecho propio,sea el correspondiente al primeramente discutido,sea al que se incorpore por via de una pretensión conexa, serán partícipes-originarios, sustitutos, litisconsortes necesarios, litisconsortes por adhesión, por intervención excluyente, terceristas de dominio y mejor derecho,intervinientes devenidos en demandados o actores -y no terceros. En cambio serán terceros los que arriban al juicio-voluntaria o coactivamente- merced a una especial legitimación que les otorga la leyno para defender un derecho propio involucrado en el juicio sino el derecho ajeno en discusión.Al efecto y si no vienen a discutir un derecho sustancial del que son titulares, no queda otro papel asignable que no sea el de ayudar , coadyuvar con el titular de tal derecho-actor o demandado según el casoubicándose a su lado. De tal manera, terceros funcionales, auténticos terceros, no son sino los coadyuvantes en tanto merezcan en propiedad el título de tales y se ubiquen en el juicio en ese rol. En tal sentido y como se verá ,no limitamos esa categoría a los coadyuvantes simples del art.92(90) inc. $1^{\circ}$ y $93(91)$,primera parte del CPCCN ,clásicamente tenidos como tales, sino que también la extendemos, diferenciándola de la anterior a los coadyuvantes calificados de los arts.96(94) y 107(105) CPCCN .

Los terceros son sujetos de rol meramente eventual, ya que a diferencia de los denominados principales-actor y demandado-no está reservado para ellos un puesto que imprescindiblemente deba ser cubierto. Los terceros funcionales pueden ser pueden ser intervinientes por 
concurrencia o por abstención. Por concurrencia desde que se manifieste su presencia material en el juicio y en cuanto asuman y mantengan la naturaleza coadyuvante de su actuación sin abandonarla para operar la de demandantes o demandados si ello resultare factible .Podrá ser tercero interviniente por abstención quien notificado de la existencia de un juicio mediante la denuncia de litis, no concurre al mismo y no obstante queda involucrado por la cosa juzgada. A la primera de estas modalidades estará dedicado el mayor desarrollo de nuestra obra pues es la que parece explicitada en los tratamientos codificados. La otra, resulta implícita en la normativa según los términos del art.98(96) CPCCN en su segunda parte. Es claro que este tercero abstinente no es el totalmente ajeno al conflicto del que se trate, carente de toda relación o interés protegible en el pleito, ajeno a toda consecuencia sobre su derecho sustancial, aun cuando pueda desempeñarse como testigo, informante o peritos, es decir fuera del campo litigante.

Teniendo lo expuesto como punto de partida, resulta necesario considerar la temática correspondiente a la acción de garantía, a fin de tener a la vista un conocimiento básico para la comprensión del sistema de la intervención obligada en el derecho argentino, de manera de poder evitar interpretaciones válidas para el derecho extranjero pero inadecuadas para el nuestro. Solamente con tal conocimiento previamente adquirido, podremos avanzar en nuestro estudio.

\section{La acción de garantía. Derecho extranjero}


En el derecho italiano, la acción de garantía es admitida como modalidad de acumulación de pretensiones, de manera que el demandado, ante el evento de resultar perdedor ante su propio actor, puede plantearla contra el tercero responsable para ser dilucidada y fallada en el mismo juicio. Ya con relación al Código de Procedimientos Civil de 1865, Chiovenda nos dice que la acción de garantía no es sino la acción de regresión anticipada in eventum. Recuerda que pese a su origen germánico no está contemplada en el ordenamiento alemán y que llega al derecho italiano desde el derecho francés asentándose en el art.193 de aquel ordenamiento, que habilitaba para que al llamamiento al pleito se agregase la proposición condicional de la acción de regresión contra el citado ("garante") para que en caso de derrota del "garantido", aquél no solo no pudiera desconocer con el presupuesto de su propia responsabilidad, sin que, al mismo tiempo, fuese condenado a responder ante el citante. El llamamiento en garantía, nos dice, puede ser en garantía simple (dirigido a cualquiera que por el hecho propio expone a otro a una acción en su contra; (por ejemplo el fiador que demandado, llama al deudor principal; o el comitente demandado por resarcimiento de los daños causados por su dependiente que llama a éste) y en garantía formal, que ocurre si se convoca al transmisor de un derecho por el cual es demandado el adquirente del mismo, caso que permite la sustitución del garantizado por el garante, ejemplo, en la evicción. ${ }^{3}$

\footnotetext{
${ }^{3}$ Chiovenda Giuseppe,. Principios de Derecho Procesal Civil, t.II,V.II,pgs 646 a 651 Traducción española de la Tercera edición italiana, por José Casais y Santaló .Editorial Instituto Editorial Reus. Madrid. 1941.
} 
Para este autor, la acción de garantía era viable tanto para la garantía simple como para la formal, pero en la primera, el garante no podrá asumir el pleito en reemplazo del citante ya que no se trata simplemente de discutir la bondad de un derecho, tema con respecto al cual, en la garantía formal, quizá no sea necesaria la presencia del garantizado ${ }^{4}$.

Chiovenda se detiene a explicar las consecuencias del trámite conjunto de la demanda originaria y de la acción de garantía, señalando que en tal caso, la relación procesal sin perder su unidad, adquiere un nuevo sujeto; resalta entonces que "El llamado es parte, porque si en los respectos de la demanda originaria podría limitarse a asistir (causae adesse) o también adherirse la defensa del llamante como si fuese un interviniente voluntario; por otro lado, la acción de regresión propuesta contra él lo hace parte en todo caso y le atribuye todos los derechos de la parte. Es, pues de aplicación, con mayor motivo para el llamado en garantía, lo que antes fue observado para el simple llamado al pleito, esto es, que él no puede ser constreñido a permanecer en el pleito sino a condición de que le será asegurada la más amplia libertad de defensa, sin recibir perjuicio por preclusiones y actos anteriormente realizados",

Especifica que dentro de la unidad de la relación procesal, acción originaria y la acción de regreso se desarrollan en forma paralela y autónoma pero en relación recíproca a la que describe diciendo "que el llamado, ya asista simplemente, ya participe adhesivamente a favor del llamante en la contienda que continúa entre éste y su adversario sobre el objeto originario del pleito, no es extraño a la contienda misma,

\footnotetext{
${ }^{4}$ Chiovenda Obra y tomo citados,pg.655/656)

${ }^{5}$ Chiovenda Giussepe, Obra y tomo citados, pg.653.
} 
precisamente porque está en ella como llamado, mientras que el llamante y el llamado contienden por cuenta propia exclusiva sobre la acción de regresión, a la cual el adversario del llamante es enteramente extraño" ${ }^{\text {. }}$ Sigue explicando que "Por otro lado, la unidad y singularidad de la relación procesal hace que los actos, las deducciones, las instancias, los documentos, aunque relativos exclusivamente a la acción de regresión, deben ser comunicados también al adversario de la parte llamante; que éste puede utilizar los documentos y las pruebas, aunque producidas o realizadas únicamente a los fines de la acción de regresión"?7.

Por su parte Calamandrei formula la que se denomina teoría procesal de la acción de garantía. Comienza por definir el contenido de la garantía que justifica la pretensión del garantizado, diciendo que "Garantía es la defensa en juicio dirigida a rechazar una demanda de un tercero o a sostener una demanda contra un tercero, y el resarcimiento de los daños derivados de la no efectuada o lograda defensa que una persona, denominada garante, está obligada a presentar por ley, o por contrato a otra persona, llamada garantizado" ${ }^{8}$. Afirma que la acción requiere como presupuesto la existencia de lo que llama "proceso de molestia" por el cual el demandante "molesta" a un sujeto con su reclamo o ejercicio de la "acción de molestia", motivo por el que el molestado, si se considera garantizado por un tercero que le transmitió el derecho, lo hace intimar (llamada en causa) fundamentalmente para que lo defienda en juicio, requerimiento que lleva implícita la acción de defensa que motivará que,

\footnotetext{
${ }^{6}$ Chiovenda Giussepe, Obra y tomo citados,pg.654

${ }^{7}$ Chiovenda Giussepe, Obra y tomo citados ,pg. 654.

${ }^{8}$ Calamandrei Piero. La Chiamate in garantía, pg 81.Societá editrice Librería. Milano. 1913
} 
no compareciendo o negándose el garante a cumplir su cometido, el juez tendrá que pronunciarse en la sentencia acerca de vigencia de la obligación de defensa y condicionada al resultado de la molestia y la acción de defensa, resolver la acción resarcitoria del garante al garantizado por lo que éste tuviera que desembolsar a favor del actor ${ }^{9}$.Calamandrei visiblemente vincula la acción de garantía con la garantía formal .

Carnelutti define el llamamiento en garantía como una de las posibilidades de extensión facultativa del proceso (ver al respecto punto 18) que debe tener como presupuesto una relación de garantía a la que define diciendo que "Se llama así a la relación por virtud de la cual una persona (garante) viene obligada a prestar a otra (garantido) el equivalente de lo que éste haya dado o perdido en virtud del cumplimiento de una obligación respecto a un tercero". Añade que puede resultar de cualquier fuente capaz de generar obligaciones, en particular de un contrato o de un acto o hecho jurídico distinto. Para el autor el llamamiento en garantía no es sino una forma de provocación para producir la intervención adhesiva del garante, ya que éste se introduce en el proceso pero no por ello incorpora una litis distinta. Pero, para los casos en que el garante lejos de prestar su adhesión, no interviene, el garantizado promueve el juicio de garantía que "se cualifica como una intervención principal a instancia de parte , mediante la cual se introduce un nuevo litigio en el proceso"10.

En el actual Código de Procedimientos Civil italiano-para el cual vale la doctrina reseñada- la acción de garantía está contenida en el art.

\footnotetext{
${ }^{9}$ Calamandrei Piero.La Chiamate ...,pgs 85 a 94.

${ }^{10}$ Carnelutti Francisco .Instituciones del Proceso Civil. V.I pgs 693 a 695.. Traducción de Niceto Alcalá Zamora y Santiago Sentis Melendo .Uthea Argentina. Buenos Aires. 1944
} 
106 en su parte final ( ver su texto en nota 112) relacionable con el art.32 en materia de competencia ${ }^{11}$.

Carnelutti al tratar el llamamiento en garantía en el actual Código de Procedimientos Civiles italiano y su art.106, repite la concepción elaborada bajo el código anterior. Dice entonces que "Cuando una relación de tal género está en juego, el movimiento del proceso en torno a la obligación principal determina el interés del garante en prestar la defensa al garantizado y, por eso, en provocar en el proceso la intervención por adhesión; en el caso inverso, en una intervención coactiva, puesto que la negación de la obligación de garantía, da lugar, entre garante y garantizado, a una litis conexa por el objeto con la litis relativa a la obligación principal" Expresa que "No obstante la diversidad de la fórmula...el requisito de la intervención coactiva es idéntico al de la intervención voluntaria principal; la litis entre las partes que ya están en el proceso, es común al tercero cuando tiene el mismo título o el mismo objeto" de donde concluye que aun cuando el art.106 "no hubiese recordado el caso de la garantía, este entraba en la primera parte de la fórmula"12.

Calamandrei nos dice que "Cuando una persona se encuentra en causa por un objeto acerca del cual un tercero está obligado, por derecho sustancial, a prestarle garantía, puede comportarse, en relación a ese tercero

\footnotetext{
11 Art.32"Causa de garantía. La demanda de garantía puede ser propuesta al juez competente para la causa principal a fin de ser decidida en el mismo proceso aunque exceda la competencia por el valor.
}

\footnotetext{
${ }^{12}$ Carnelutti Francesco. Instituciones del Proceso Civil.traducción de la quinta edición italiana de Foro Italiano.Roma.1956 por Santiago Sentis Melendo. V.I, pgs.398 y 399. EJEA.Buenos Aires.1973.
} 
garantizador, de dos maneras diferentes; puede limitarse a llamarlo en causa (cfr en cuanto a la garantía proveniente de la venta art.1485 C.C), al solo efecto de informarlo de la pendencia de la causa principal; o puede llamarlo en garantía, proponiendo contra él, al mismo tiempo que lo llama a la causa principal, la demanda de garantía es decir de regreso (art.32)" 13

En el derecho español a falta de disposiciones expresas, la doctrina centró el tema en torno de la garantía de evicción, discutiéndose si la misma- en cuanto el adquirente requiere en el juicio la citación del enajenante-, significa o no la deducción de una pretensión en su contra, al estilo del sistema italiano. Por la negativa se inclinan, entre otros, Prieto Castro $^{14}$ y Montero Aroca ${ }^{15}$ en coincidencia con los términos del art.1480 del Cod.Civil que remite la efectivización del saneamiento a momento ulterior al que corresponda a la sentencia que haga perder al adquirente la cosa de la que se trate ${ }^{16}$. Por el contrario, para Serra Domínguez es posible acumular en la causa del tercero contra el adquirente, la acción de éste contra quien fuera su enajenante sin que el art.1480 sea un obstáculo para

\footnotetext{
${ }^{13}$ Calamandrei Piero. Instituciones de Derecho Procesal Civil. Según el Nuevo Código, V.II,pg. 345. Traducción de la primera edición italiana Cedam 1944, por Santiago Sentis Melendo. EJEA. Buenos Aires.

${ }^{14}$ Prieto Castro Leonardo. Derecho Procesal Civil ,t.I,pg.298. Revista de Derecho Privado.Madrid.1964

${ }^{15}$ Montero Aroca Juan. Ortells Ramos Manuel. Gómez Colomer Juan Luis. Derecho Jurisdiccional, t. II, $1^{\circ}$ pg. 56), Librería Bosch. Barcelona. 1989.

${ }^{16}$ Art.1480.'El saneamiento no podrá exigirse hasta que haya recaído sentencia firme, por la que se condene al comprador a la pérdida de la cosa adquirida o de parte de la misma"
} 
ello, fundamentalmente en razón de la posibilidad normativa- de plantear pretensiones subsidiariamente ${ }^{17}$.

En los ordenamientos procesales sudamericanos que computamos, la acción de garantía a la manera franco- italiana aparece consagrada en los arts. 59 CPC Bolivia de próxima vigencia; arts 76, 77,78,79,80 CPC Brasilcon una amplia gama de posibilidades de ejercicio - y 331 y 332 del proyecto de reformas; 57 ex CPC Colombia, actual 64 a 66 CGP de ese país, 104 CPC Perú, 51 CGP Uruguay y 38 CPC Venezuela.

\section{La acción de garantía Derecho argentino}

a) Introducción. Como lo anticipamos, la acción de garantía bajo la modalidad eventual prevista en el derecho italiano, no aparece expresamente consagrada por el CPCCN ni por el resto de las normativas procesales argentinas ${ }^{18}$, aun cuando será preciso considerar separadamente el caso significado por el art. 31 primera parte in fine de la ley General del ambiente (ley 25.675) y el de la tercera parte del art.98(96) CPCCN si bien con respecto a éste, adelantamos que no se trata de un supuesto de acción de garantía. Ver al respecto, punto 102 b.

b) Criterio aplicable. Si tomamos como pauta el art. 108(96) CPCCN en materia de evicción -aplicable por analogía- y (con más razón a los casos que la doctrina europea designa como de garantía simple y en los que hasta resulta improcedente conforme autorizadas voces, el ejercicio de la

\footnotetext{
${ }^{17}$ Serra Domínguez Manuel. Intervención del vendedor en el proceso de evicción, en Estudios de Derecho Procesal, pg 271 y 272. Ediciones Ariel. Barcelona.1969

${ }^{18}$ Tampoco la encontramos en el Código Civil y Comercial de la Nación(art.1773 ) donde se observa que entre las acciones de responsabilidad que prevé, figura la posibilidad de ejercicio conjunto o separado contra los responsables directo e indirecto del daño, pero no la de acumular a ellas la acción de regreso,
} 
acción de garantía) tendríamos desde ya un elemento contundente para rechazarla entre nosotros. De todas maneras avanzaremos en el tema ya que tampoco existe una prohibición expresa y el art.108(106) CPCCN interpretado con amplio criterio, podría llevar a sostener que no por citación pero si por demanda expresa, podría admitirse la acumulación y ello en la práctica sería lo mismo.

Comenzaremos por recordar que la jurisprudencia se inclina por considerar que dicha modalidad no es admisible ${ }^{19}$ y en ello coincide la doctrina $^{20}$.

Es claro que resulta posible no solamente acumular pretensiones conexas (art.90(88) CPCCN) sino también hacerlo con una pretensión principal y otra subsidiaria cosa que, de todos modos, significa proponer a la discusión bajo otro enfoque, el mismo conflicto ya producido y por el que se inicia el pleito. En este caso, la segunda pretensión se introduce para jugar subordinada a la procedencia de otra subordinante (por ejemplo, acumular a la pretensión de rescisión contractual la de restitución de la cosa, para que se decida en caso de que la primera fuere resuelta favorablemente; pedir junto al divorcio, la disolución de la sociedad conyugal con la consiguiente entrega y/o restitución de bienes). Pero no es lo mismo una pretensión subordinada que una pretensión eventual. Como puede verse, en aquélla se trata de hacer valer las consecuencias de un

19 CS 13/12/1920 Municipalidad de Tucumán c/Ferrocarril Central Córdoba s/reivindicación (Fallos 133:140), en la que especificó, si bien con referencia a la evicción, que el reclamo al garante por saneamiento no puede hacerse en la reivindicación sino que la garantizada deberá recurrir a un juicio específico.

${ }^{20}$ Martínez Hernán J. Procesos con sujetos múltiples, $2^{\mathrm{a}}$ edición actualizada, pgs 333 a 336.La Ley.Buenos Aires.2014;Palacio Lino E. Derecho Procesal Civil, Segunda edición actualizada por Carlos Enrique Camps,T.III,pg.215.Abeledo Perrot.2011 
conflicto ya configurado para que se resuelvan en el mismo fallo conforme el efecto ex tunc de las sentencias de condena. Si bien es eventual que el fallo pueda considerarla, no lo es la pretensión en sí, ni tampoco lo es el enfrentamiento-con los hechos consiguientes-efectivizado con anterioridad al reclamo judicial.

La pretensión eventual es en cambio la que se vincula con un conflicto no producido al momento de ser planteada. La viabilidad de su admisión depende del ordenamiento jurídico. Si éste no la autorizara, la jurisdicción aparecería llamada para resolver una cuestión abstracta en base a un enfrentamiento meramente supuesto, tarea que resulta claramente ajena a dicha función y por tanto convierte tal pretensión en inadmisible. Es precisamente lo que ocurre con las acciones de regreso ya que en ellas, la causa de la obligación del considerado responsable nace recién cuando el perdedor satisface la condena y busca resarcirse, y por lo tanto es ante el incumplimiento del obligado, cuando se produce el conflicto.

Defendiendo la viabilidad de la acción de garantía en el derecho español, Serra Domínguez, con argumentación que bien puede servir para el derecho argentino, sostiene que resulta factible receptar el reclamo regresivo al dictarse sentencia condenatoria en las instancias ordinarias, sujeta a que sea refrendada en su validez por la casación, pues ya para aquél momento, el tribunal de grado ha determinado la existencia de un perjuicio resarcible ${ }^{21}$. Nos parece que no cabe una sumatoria de eventualidades: la de la pretensión y la de la sentencia, ya que si el fallo no está firme no hay perjuicio cierto a resarcir y por ende se mantiene el

\footnotetext{
${ }^{21}$ Serra Dominguez Manuel. Obra citada,pg.271)
} 
estado de abstracción que no puede ser objeto de pronunciamiento en ninguna de las instancias.

Queda sin embargo un punto pendiente: Calamandrei resalta que en la garantía formal el garante está obligado a asumir la defensa del citante garantizado, de manera que señala un objeto no resarcitorio que bien podría justificar la acumulación que nosotros negamos. Veremos en el punto 39 qué ocurre al respecto con el equivalente local, es decir la evicción ${ }^{22}$.

c) La ley general del ambiente. La ley 25.675 establece en su art.31 una solución específica para los casos de responsabilidad solidaria en la provocación del daño ambiental colectivo ${ }^{23}$. Así el juez determina la responsabilidad de los causantes del daño ambiental. Si puede establecer que el perjuicio no genera responsabilidad solidaria, fijará la de cada uno a los efectos de su pago. De resultar obligaciones solidarias-que nos parece es el caso natural- se fijará el monto global que cualquiera de los responsables deberá abonar en su totalidad. Pensamos que pese a la redacción de la norma, que parece admitir la condena directa de todo el que apareciere como causante, no podría fijarse monto alguno sino con respecto a los que fueran demandados o a quienes solamente citados como terceros hubiesen pasado a serlo según el régimen que denominamos como "demandabilidad implícita"-ver punto 100c-. A partir de allí jugará el

\footnotetext{
${ }^{22}$ No incluimos la consideración del caso de la garantía formal en el seguro, dadas las peculiaridades del sistema. Ver sin embargo, en el punto 38 su tratamiento básico.

${ }^{23}$ Art.31 Ley 25.675"Si en la comisión del daño ambiental colectivo, hubieren participado dos o más personas, o no fuere posible la determinación precisa de la medida del daño aportado por cada responsable, todos serán responsables solidariamente de la reparación frente a la sociedad, sin perjuicio, en su caso, del derecho de repetición entre sí para lo que el juez interviniente podrá determinar el grado de responsabilidad de cada persona responsable."
} 
sistema común de relaciones entre los codeudores solidarios (art. 716, 717 y 689 Cód. Civil; art.840 CCCN) a ejercerse mediante las acciones respectivas. Es decir que no se trata de derivaciones de una acción de garantía sino de una condena a los demandados actuales. Podrá aplicarse también el régimen ejecutorio derivado de la última parte del art.96(94) CPCCN, según la ley 25.488 que permite ejecutar a favor del demandado perdedor, a los terceros citados por éste, en tanto hayan concurrido como coadyuvantes a su defensa. Tampoco hay aquí un juzgamiento acumulado de acción de garantía contra terceros, sino de un reconocimiento anticipado por ellos de la existencia de una obligación de resarcir al demandado para el caso de ser derrotado. Al respecto nos remitimos a lo expuesto en el punto 102 a.

\section{Pretensiones declarativas y sentencias monitorias}

No hay confusión posible entre la acción de garantía eventual y las pretensiones declarativas, ya que éstas si bien tienen una función preventiva de conflictos hipotéticos (pero de altamente posible producción dadas las condiciones objetivas de la relación sustancial), resuelven las situaciones de incertidumbre referidas por el art.322 CPCCN derivadas de la existencia de puntos de vista encontrados, situación que desde ya conforma un conflicto de existencia real y actual, aun cuando no se haya producido el que pueda resultar del incumplimiento, que, precisamente se quiere evitar.

En cuanto a las sentencias monitorias, no empecen nuestra conclusión pues operan -por lo menos en nuestro derecho, ver por ejemplo 
arts.463 CPCC La Pampa y 463 CPCC San Juan- con un conflicto planteado, es decir presente y no hipotético.

\section{Las condenas de futuro}

No es tan sencillo descartar la existencia de una pretensión eventual ante el fenómeno de las condenas de futuro-art.687(688) CPCCNprevistas para los casos de desalojo anticipado de inmuebles. A primera vista se ve que ellas refieren un conflicto que no se ha producido y no se sabe si ha de producirse; sin embargo habrá una sentencia que se anticipa a resolverlo; pero, si se observa atentamente el instituto, se advierte que la pretensión deducida apunta no a decidir un enfrentamiento meramente contingente, sino a crear por vía no contenciosa, una declaración judicial con valor monitorio destinada a ser aplicado ante un conflicto futuro. En efecto, la demanda prosperará ante la conformidad de la demandada y de inmediato nacerá el título-sentencia que no habrá juzgado un enfrentamiento no producido, sino homologado la coincidente voluntad de las partes. Por el contrario, si hubiese oposición, se estará generando un conflicto presente y real que como tal deberá ser resuelto con un fallo que decidirá el punto y en su caso, generará el título referido. 


\section{Las acciones preventivas}

El CCCN (Ley 26.994), prevé específicamente la acción preventiva para evitar o en su caso atenuar un daño jurídicamente injustificado ${ }^{24}$. La acción preventiva puede entonces plantarse por amenaza pre -daño o por amenaza post daño. Las primeras son las que apuntan a evitar se produzca el evento nocivo. El orden jurídico vigente establece diversas acciones de ese tipo: la Constitución Nacional consagra la acción de amparo ante amenazas a derechos (art.43); el CPCCN hace lo propio con el interdicto de retener ante la proximidad de actos de perturbación (art.600(610) inc. $2^{\circ}$ ), o de riesgos físicos en el interdicto de daño temido (art. 614(623 bis).

Las acciones post- daño pueden ser de finalidad interruptiva o de finalidad impeditiva. Las interruptivas se dan cuando el daño está produciéndose y la actividad nociva se mantiene; están entonces destinadas a impedir su continuidad. Ejemplos: en los art.1071 bis Cód. Civil y 1770 $\mathrm{CCCN}$, en tanto la violación al derecho a la intimidad se esté produciendo ; art.71 CCCN, en el uso del nombre propio por extraños; en el interdicto de oposición a reparaciones urgentes (art.615(623) ter. CPCCN. );en el interdicto de obra nueva (art.609(619) CPCCN);en el amparo previsto en la tercera parte del art.30 de la ley general del ambiente (Ley 25.675). Las impeditivas operan cuando el daño se encuentre causado, pero subsiste la amenaza de que se profundice o reinicie sea por el recomienzo de la acción deteriorante, sea por el obrar humano, sea por la propia naturaleza. Es decir que se trata de peligro permanente.

\footnotetext{
${ }^{24}$ Artículo 1711.Accion preventiva. La acción preventiva procede cuando una acción u omisión antijurídica hace previsible la producción de un daño, su continuación o agravamiento. No es exigible la concurrencia de ningún factor de atribución
} 
En las acciones pre-daño nos encontraremos con una situación real y actual de peligro (por ejemplo, un acto administrativo ilegal en condiciones de ejecutarse, la amenaza concreta de actos turbatorios, un estado de cosas configurativo de peligro de derrumbe). Es decir entonces que también aquí el conflicto está presente y habrá de resolverse sobre su aptitud para producir perjuicios frente a una obligación de abstención (art.1710 CCCN) o de cuidado (por ejemplo,art.42 ley de residuos industriales, Ley 25.612). También en las acciones post- daño, el conflicto está planteado, es actual por la existencia de amenazas si se quiere repotenciadas por la producción de daños anteriores; por tanto, las acciones correspondientes no puede ser confundidas con las que hacen a enfrentamientos meramente eventuales.

\section{SECCION SEGUNDA}

\section{APROXIMACION A LA INTERVENCIÓN TERCERISTA}

\section{Precisiones}

En esta sección consideraremos algunos fenómenos procesales (la adhesión, la coadyuvación y la sustitución) y tipos de intervenciones de terceros (intervención voluntaria) cuyo repaso nos han de proporcionar una base adecuada para adentrarnos en el estudio del tema central de este trabajo, es decir, la intervención obligada.

\section{La adhesión}


Adherir significa tomar como propia la posición de otro, su conducta, sus actos; en lo procesal, hacer lo mismo con lo actuado por alguno de los sujetos originarios. Ahora bien: cualquier acto de un sujeto procesal puede merecer la adhesión de otro (por ejemplo, manifestar que adhiere al pedido de libranza de un oficio o de citación de un tercero).No es con ese sentido que consideramos tal palabra, sino con el significado de adopción, por parte del tercero, de la posición tomada por el adherido con respecto a la pretensión o a su respectiva defensa. El concepto de adhesión no es usado literalmente por el CPCCN (tampoco por los códigos que le sirven de fuente, salvo el CPC de Mendoza en su art.109), pero admitido por la doctrina, refiere una actitud voluntaria: la del tercero que adviene al proceso por propia iniciativa. De ahí que toda intervención voluntaria de terceros sea adhesiva y supone la preexistencia de una postulación formulada por un sujeto-parte originaria- a la que se toma como propia; por lo demás debe producirse sin alterar la marcha del juicio de modo que el ingreso sea in statu et terminis. Ello coloca al tercero en la necesidad de cubrir el vacío inicial de su presencia, "adhiriendo" a lo ya actuado y sustentado por el adherido. Se ubicará de esa manera en el campo actor o en el demandado según su pertenencia al derecho que se debata o su interés en la medida en que pueda quedar afectado por el juicio. Desde ya que adhesión no es coincidencia. Coinciden los litisconsortes originales al demandar o contestar la demanda.

La adhesión importa la existencia de un vínculo constitutivo entre adherido (parte originaria) y adherente que condiciona la actuación del segundo, impidiéndole generar un campo de conflicto que reemplace al originario delimitado por el primero, si bien y según el momento de su llegada y su calidad de normativa, tendrá dimensiones distintas en sus posibilidades de actuación. Al efecto, la ley procesal establece diversas 
legitimaciones; así puede hablarse del tercero adhesivo simple o del tercero adhesivo litisconsorcial cuyas respectivas temáticas se verán en el punto $\mathbf{1 2}$, con la característica común de tratarse de intervenciones voluntarias. De tal manera la adhesión no puede jugar en intervenciones coactivas, salvo que se considere que la intervención del art.98(96) CPCCN, es esencialmente voluntaria, criterio que, anticipamos, no compartimos. En otro orden de cosas, se advierte que la intervención obligada alemana o italiana puede ser adhesiva en tanto se produzca más allá de la etapa constitutiva; no así la nuestra, pues debe darse, precisamente, en ese periodo.

La presencia del adherente no fuerza el alejamiento del adherido ni permite al primero operar como sustituto del segundo.

\section{La coadyuvación}

Coadyuvar significa ayudar ${ }^{25}$, apoyar ${ }^{26}$. Para el caso de una actuación procesal, contribuir a la causa de otro. De tal manera, coadyuvar es aportar al triunfo de una de las posiciones enfrentadas en el juicio. Así, y si bien la adhesión no puede asegurar la coadyuvación-salvo que se trate de adherente simple-es altamente posible que el adherente coadyuve con el adherido. Lo dicho demuestra que coadyuvación y adhesión son fenómenos diversos de modo que puede existir adhesión sin coadyuvación, pero también coadyuvación sin adhesión. Lo primero se dará si el ingresante del art.92(90) inc. $2^{\circ} \mathrm{CPCCN}$, aprovecha de la posición del coadyuvado pero no

\footnotetext{
${ }^{25}$ El CPCC Mendoza emplea el concepto de ayudar, art 111

${ }^{26}$ El art.303 CPC Santa Fe utiliza el verbo apoyar.
} 
le aporta nada a su favor. Lo segundo, si el tercero no queda comprometido a seguir la línea defensiva del otorgante originario, pero por la naturaleza propia de su función procesal lo beneficia con su operatoria. Ejemplo, interviniente del art.96(94) CPCCN. Es entonces preciso tener presente que la adhesión no es la única fuente de la coadyuvación ya que ésta puede resultar de otro fenómeno como luego lo explicaremos.

En las codificaciones es utilizado el concepto de coadyuvar, o mentada la figura del coadyuvante ${ }^{27}$, uso que no hace el CPCCN, silencio que sin embargo no obsta para que la doctrina vincule exclusivamente la figura descripta en los artículos 92(90) inc. $1^{\circ}$ y 93(91) primera parte CPCCN con el adherente simple y solamente denomine coadyuvante a tal adherente ${ }^{28}$ a quien también suele llamársele asistente ${ }^{29}$.

El tercero coadyuvante no es representante del coadyuvado $^{30}$ ni tampoco sustituto procesal (ver punto 10), así como que su presencia no

\footnotetext{
${ }^{27}$ Art. 77 CPC Jujuy; arts 104 y 109 CPC Mendoza; arts 302 y 306 CPCC Santa Fe

${ }^{28}$ Por ejemplo, Palacio Lino E. Derecho...citado.T.III, pg.204

${ }^{29}$ Alvarado Velloso Adolfo. Introducción al estudio del Derecho Procesal, Segunda parte, pgs 146 y 147.Rubinzal-Culzoni.Santa Fe. 1998
}

30 Kisch parece sostener la condición de representante legal del coadyuvante; en tal sentido expresa que obra no a la manera de la simple asistencia sino con los mismos efectos jurídicos de un representante y dice que ello es indudable a la luz de los preceptos expresos de la ley, pero a poco niega que representación y coadyuvación puedan ser confundidas y se inclina por descartar la primera y adoptar la segunda. (Kisch W. Elementos de Derecho Procesal Civil, pgs 322 y 323. Traducción de la cuarta edición alemana y adiciones de derecho español de L .Prieto Castro, Segunda Edición, Revista de Derecho Privado. Madrid. 1940.) Las diferencias son marcadas, ya que no existe mandato entre coadyuvado y coadyuvante, ni la ley lo determina expresa o tácitamente, ni los actos del coadyuvante comprometen desfavorablemente al coadyuvado, no se hacen en nombre de éste y, fundamentalmente, el primero obra en función de una legitimación propia y perfectamente distinguible de la del segundo. Tampoco nos parece que pueda denominársele asistente pues ello menta una relación de 
altera la titularidad del coadyuvado en su derecho sustancial. Todo tercero coadyuvante será alcanzado por la cosa juzgada resultante (art. 96 CPCCN).

Encontramos dos formas básica de coadyuvación: una es la coadyuvación indirecta o impropia, correspondiente a la figura del litisconsorte de los arts.92(90) inc. $2^{\circ}$ y 91 segunda parte $\mathrm{CPCCN}$, forma en la que la actividad del coadyuvante apunta a defender el derecho propio y no el del coadyuvado, pero permite volcar en la proporción que sea y no siempre, un aporte a la causa de dicho sujeto procesal. Es una coadyuvación por consecuencia, meramente eventual pues se producirá en la medida en que la defensa propia contenga elementos que, generalizados, puedan contribuir a la defensa del derecho del co-litigante, cosa posible, ya que, lo recordamos, como voluntaria, la intervención del tercero será adhesiva.

La otra es la coadyuvación directa o propia, significada por quien ingresa para defender un derecho ajeno en nombre de un interés propio, bajo el que subyace la defensa de un derecho propio que puede ser afectado indirectamente por el fallo del juicio al que se arriba. Es una coadyuvación de natural inherencia al sujeto procesal que la práctica y que según sus características puede darse por subordinación (coadyuvación simple, arts.92(90) inc.1 y 93(92) primera parte $\mathrm{CPCCN}$ ) o por concordancia (coadyuvación calificada).

dependencia que no existe entre coadyuvante y coadyuvado. La diferenciación efectuada vale para todo tipo de coadyuvante 
El coadyuvante por concordancia ${ }^{31}$ es básicamente el interviniente obligado del art.96(94) CPCCN-no adhesivo- y el garante de evicción en su caso. Es prematuro referirnos ahora a la naturaleza y eficacia de la actuación de tales sujetos por lo que nos remitimos a lo expuesto en los puntos 95 y 96 en cuanto al primero y al punto 39 en lo referente al segundo.

\section{La sustitución}

a) La doctrina. Un breve recorrido por doctrinan y jurisprudencia en materia de sustitución nos permite advertir cierta latitud en la utilización del instituto. Chiovenda dice que sustituto es quien comparece al juicio en nombre propio por un derecho ajeno sin ser su representante, en virtud de un vínculo jurídico tendido entre si y el sustituido ${ }^{32}$. Jaime Guasp refiere a la sustitución como el fenómeno producido cuando "la norma procesal legitima como partes a sujetos que, sin ser titulares de la relación jurídica discutida, no actúan tampoco en nombre del verdadero titular, a veces indeterminado e incierto, sino en nombre propio, aunque haciendo valer derechos o soportando obligaciones indiscutiblemente ajenas" 33 .

\footnotetext{
${ }^{31}$ Lo denominamos así, no porque acuerde su postura con el coadyuvado, sino porque no siendo adhesivo, el juez tendrá que ver de ensamblar sus postulaciones y pruebas con las del citante para determinar en qué medida y alcance ha contribuido a su causa.

${ }^{32}$ Chiovenda Giussepe. Obra citada, tomo II, p.28

${ }^{33}$ Guasp Jaime, Derecho Procesal Civil, Cuarta edición. Revisada y adaptada por Pedro Aragoneses, Tomo I, pg.178, Civitas. Madrid. 1998.).
} 
Palacio define diciendo que "Existe sustitución procesal cuando la ley habilita para intervenir en un proceso, como parte legítima, a una persona ajena a la relación sustancial controvertida, aunque jurídicamente vinculado por un derecho o por una obligación de garantía, a uno de los partícipes de dicha relación" 34 . Colombo-Kiper expresan que "Cuando en el proceso por obra de una disposición de la ley sustancial, interviene una persona que ejecuta un derecho de otro pero en interés propio -a diferencia del mandato en que se ejerce el derecho de otro en interés de éste- se producen una serie de relaciones entre el contrario, el sustituido (el titular del derecho) y el sustituto (el que pase a ejercerlo)",35. Satta nos dice que no puede verse en el instituto sino la presencia de un derecho propio: "Pero si el legislador se hubiese sólo preguntado qué es lo que constituye la base de este "hacer valer en nombre propio un derecho ajeno" no habría dejado de observar que en su base está simplemente un derecho; y por tanto, no un derecho ajeno que hace valer el denominado sustituto sino un derecho propio, como cualquier otro legitimado". Para el maestro "el término de sustitución procesal resulta en absoluto vacío de sentido" pues de lo que se trata es de una hipótesis de "interferencia entre relaciones jurídicas"; explica que "hay relaciones que no se agotan en la esfera jurídica de los sujetos que las pusieron en acto, sino que interesan o no con su constitución o con su desenvolvimiento a otra relación, establecida entre uno de esos sujetos y un tercero" y que "cuando la primera afecta a la segunda afectando el derecho

\footnotetext{
${ }^{34}$ Palacio Lino E. Derecho... citada. Tomo III. pg.287)

${ }^{35}$ Colombo Carlos J-Kiper Claudio M. Código Procesal Civil y Comercial de la Nación. Anotado y Comentado. T.I, pg 361. La Ley ,2ª edición. Buenos Aires. 2006
} 
de este último, justifica que intervenga en aquella para tutelar su propio derecho $" 36$.

De todos modos niega que el garante pueda ser sustituto del garantizado, ya que, afirma "está en juicio a nombre propio para atender una obligación propia:la circunstancia de que no sea titular del derecho que defiende carece de relevancia, porque en realidad él afirma la titularidad de ese derecho como presupuesto de la transmisión operada"37.

Micheli, después de recordar la excepcionalidad del juego sustitutivo según el art.81 CPC de Italia, dice que la misma, al permitir que se obre en nombre propio por un derecho ajeno "encuentra su justificación de política legislativa en la exigencia de reconocer también a los sujetos que no son titulares de un derecho el poder de provocar la tutela jurisdiccional respecto del derecho mismo, en cuanto éste último es el presupuesto necesario de posiciones sustanciales de las que es titular el sustituto, o bien este último es portador de un interés sustancial (por ejemplo, a la administración de la dote durante el matrimonio) que es estrechamente conexo al derecho en cuestión, o todavía el sustituto tiene una obligación frente al sustituido (garante) o finalmente este último está obligado (en fuerza del art.2740 del cód. civ.) a responder con todos sus bienes frente al sustituto acreedor" ${ }^{38}$.

\footnotetext{
${ }^{36}$ Satta Salvatore. Manual de Derecho Procesal Civil.V.1.pg 95.Traducción de Santiago Sentis Melendo y Fernando de la Rúa de la Séptima edición de Diritto Processuale Civile.CEDAM.Dott.Antonio Milani. Milano. Padova. 1967. EJEA. Buenos Aires. 1971

${ }^{37}$ Satta Salvatore. Obra citada.pg 150

38 Micheli Gian Antonio. Curso de Dereho Procesal Civil,V.I,pgs 234 y 235. - Traducción de Santiago Sentis Melendo de Corso di Diritto Processuale Civile.Dott.A Giuffré.Milano.1959 .EJEA.Buenos Aires, 1970.
} 
Por su parte Hugo Rocco, descree de la realidad del fenómeno: dice que "no es otra cosa que el producto de una concepción híbrida del derecho de acción ,común a todos aquellos que, a pesar de todo, tienen todavía una concepción privatística del derecho de acción, o que, aun admitiendo una concepción publicística, no llegan a considerar, sin embargo, el derecho de acción completamente independiente del derecho sustancial". Expresa que en el derecho procesal se muestran quienes que sin ser titulares de derechos sustanciales "aparecen como sujetos o titulares del derecho de acción" de donde extrae la inexistencia de una inexorable relación entre derecho sustancial y legitimación. Entiende entonces que corresponde hablar de legitimaciones extraordinarias ya que, "el pretendido fenómeno de la sustitución procesal, es decir del ejercicio de un derecho de acción ajeno en nombre propio desde el punto de vista del derecho de acción, no existe, ya que los sujetos legitimados por las normas procesales para ejercitar una acción que tenga por objeto unas relaciones jurídicas de las cuales no sean titulares, son, sin embargo, titulares de la acción, es decir ,accionan en nombre propio en orden a la declaración de certeza de una relación jurídica ajena" ${ }^{39}$. Podetti, se remite a la concepción de Carnelutti, si bien incorpora la distinción entre sustitución espontánea, que identifica con la acción subrogatoria del art.1196 del Cód. Civil y la provocada que entiende se corresponde con la citación de evicción. El autor explicita que la sustitución muestra un costado contradictorio pues en tanto la norma persigue la actuación de la ley a favor del sustituido, el sustituto está legitimado para obrar; tratando de superarlo, dice que en realidad existen

\footnotetext{
${ }^{39}$ Rocco Hugo. Tratado de Derecho Procesal Civil. Tradución del Trattato di diritto procesuales civile por Santiago Sentís Melendo y y Marino Ayerra Redín,T.I. Reimpresión inalterada, pgs.365 a 368.Temis (Bogotá)-Depalma -(Buenos Aires). 1976.
} 
dos fundamentos y dos legitimaciones independientes entre sí. Una se tiende entre sustituido y su obligado; la otra entre el sustituido y el sustituto; la primera brinda la base necesaria para poder accionar; la segunda para poder sustituir ${ }^{40}$. Enrico Redenti afirma con relación a la citación en garantía del art.106 del CPC italiano "Aquí el garantido no deja en realidad de ser parte en sentido sustancial respecto de la acción (causa) principal, pero, sin embargo, se deja o se hace sustituir en el proceso (y por tanto en las funciones procesales) por el garante, y de ahí que se retire de la escena. Las funciones procesales del garante en interés del garantizado, se extienden por su parte hasta asumir carácter vicario, y no ya sólo de simple colaboración en la defensa, pero siempre y sólo dentro del ámbito del proceso. La causa sigue siendo del garantido, y por eso la sentencia de fondo despliega también siempre sus efectos "contra él” y, lógicamente, también "para el" si le fue favorable" ${ }^{41}$.

La ejemplificación que nos brindan los autores dista bastante de ser uniforme y que a nuestro juicio revela -por lo menos a la luz del derecho argentino- un buen grado de confusión desde que se identifican como de sustitución,casos que no son sino muestras de representación. Al respecto, Micheli alerta acerca de la heterogeneidad de las hipótesis que suelen encuadrarse en el concepto de sustitución procesal, denominación de la que, de todos modos, muestra dudas en cuanto a su corrección para identificar el fenómeno. ${ }^{42}$. Dice Pallares que "La sustitución procesal no fue analizada por los autores clásicos. Se debe a los jurisconsultos

\footnotetext{
${ }^{40}$ Podetti J Ramiro. Obra citada, pgs.46 y 47. Ediar. Buenos Aires. 1971

${ }^{41}$ Redenti Enrico. Derecho Procesal Civil. T.1.pgs. 326 y 327. Traducción Santiago Sentis Melendo y Mariano Ayerra Redín. .Dotto A. Guiffré. 1952.

${ }^{42}$ Micheli Gian Antonio.Obra citada,pgs 234 y 235
} 
modernos haber precisado esta figura procesal. Consiste en el hecho de que una persona autorizada por la ley, ejercite una acción o haga valer un derecho que no son suyos sino de otra persona, pero al obrar de esta manera actúa, no como representante legal o convencional del titular de la acción o del derecho, sino en nombre propio. Esta última circunstancia es la característica de la sustitución procesal y por ello no debe confundirse al sustituto procesal con el procurador judicial, con el apoderado o mandatario, con los representantes legales, ascendientes o tutores, albaceas, síndicos, etc. Todos estos obran en nombre y representación del titular de la acción que ejercitan. El sustituto lo hace por su propio derecho"43.

Por nuestra parte vemos que varios autores consideran sustituto al capitán de la nave cuando,en cambio, en el ámbito privado es representante de los armadores y propietarios no domiciliados en el lugar en todo lo referente al buque y a la expedición, (Ley 20094, arts 201 y 202); de la misma manera ocurre con el agente marítimo con respecto a aquéllos, en las condiciones de los arts.193 y 194 Ley 20.094. En esos términos no aparecen sustituyendo a nadie sino que se trata de una función de representación ex legge derivada de las relaciones típicas del tráfico naval.

En materia concursal la concepción clásica considera al síndico como un sustituto es decir reemplazando a los acreedores ${ }^{44}$.En cambio, la doctrina moderna lo ve como un órgano del concurso cumpliendo las funciones que la ley establece ${ }^{45}$; tal manera, vemos que el síndico es funcionario de la

\footnotetext{
${ }^{43}$ Pallares Eduardo .Derecho Procesal Civil, pg.240 .Editorial Porrúa. México. 1961).

${ }^{44}$ Sajón Jaime. Concursos. Ley 19.551, pg.595. Abeledo Perrot. Buenos Aires.1974.

${ }^{45}$ Vítolo Daniel Roque. Comentarios a la Ley de concursados y quiebras 24.522, pg.395. Ad-Hocc,pg.394/95.Iaed. Buenos Aires. 1996). Ver la evolución en Bonfanti
} 
quiebra (art.251 ley 24.522), responde al juez, actúa de conformidad con el orden jurídico en el régimen falencial y como tal puede operar por sí, pero lo hará en función de ese orden, que le asigna un papel específico para que pueda hacerse presente no el interés de los acreedores tomados individualmente, sino el de la masa o de los acreedores en cuanto conforman la masa. En ningún caso se observa que el síndico tenga derecho subjetivo de asunción de defensa con exclusión de los acreedores, sino que ello ocurre por imperio del orden jurídico y sin que el fenómeno ingrese en su patrimonio personal . El art.119 de la ley 24522 somete al síndico a las decisiones de los acreedores para iniciar acciones por ineficacia de los actos del deudor en el período de sospecha pero en tal caso, si algo indica, es que no los sustituye sino que los estará representando, mostrando así otra faceta de su función. Los acreedores que operan en defecto del síndico (art.120, ley 24.522) no lo sustituyen pues como se dijo, no juega ningún derecho subjetivo propio que pueda ser objeto de desapoderamiento o uso por otro. Tales acreedores ejercen una especial legitimación que la ley les concede para obrar en defensa del interés de la masa en caso de inactividad del auxiliar judicial.

El administrador de un sucesorio es a la vez auxiliar del juez y representante de los herederos. No los sustituye pues ninguno de ellos tiene por sí y de manera excluyente el derecho de administrar. Pareciera que en la dote-desaparecida del derecho argentino- también se da un supuesto de sustitución, ya que el marido adquiere a través de su derecho de administración de los bienes dotales-que siguen siendo de la esposa-la exclusividad posibilidad de defender en juicio un derecho de su cónyuge.

Bonfanti Mario Alberto-Garrone José Alberto. Concursos y quiebras, pgs 80 y821.Tercera edición. Abeledo Perrot. 1978. 
Tampoco genera sustitución el ejercicio como propias de defensas ajenas: en ciertos casos, la norma jurídica permite que sin operarse el traspaso del derecho de defensa en juicio de su titular a otro sujeto, éste último puede utilizar para la protección de su propio derecho sustancial, elementos de defensa de un derecho sustancial del que no es titular. En ese caso no está defendiendo el derecho ajeno sino el propio con elementos extraños de los que la ley le permite servirse. Así por ejemplo, el caso del usufructuario, tomado por Guasp como perteneciente a la sustitución, nos muestra que de acuerdo al art.507 del Cód. Civil español, el usufructuario no hace sino cobrar -con o sin fianza y/o autorización-créditos que hacen a su derecho. En situación equivalente en el derecho argentino, el usufructuario ejerce un derecho propio de cobro de créditos o rentas a los deudores que originariamente pertenecía al nudo propietario, pero no pueda hacerlo judicialmente sin su concurso (art.2875 Cód. Civil).Ello indica la necesidad de la presencia de dicho sujeto para seguridad de los deudores pero no que sustituya al usufructuario en su derecho a percibir, ni que éste se encuentre sustituyendo al nudo propietario que ya tiene perdido tal derecho en favor de aquél.

En la misma materia puede recordarse que el usufructuario puede utilizar en defensa de su derecho todas las acciones del nudo propietario (art. 2876 Cód.Civil) cosa que significa que tales acciones no hacen sino integrar su derecho de usufructo. Por ende no sustituye en la defensa de un derecho ajeno sino que defiende un derecho propio. El art.2877 Cód.Civil determina que las acciones que fuera del supuesto del art.2875 Cód.Civil pueda encarar el usufructuario, en caso de victoria tendrán un efecto benéfico para el nudo propietario, pero no se trata del resultado de la sustitución sino de las consecuencias del ejercicio de derecho propio del 
primero y a tal punto no se estará sustituyendo al propietario que este no es alcanzado por la derrota del el usufructuario.

Algo similar ocurre con el fiador que está habilitado a utilizar las defensas del afianzado (arts 2020, 2021, 2022 y 2023 Cód.Civil; art. 1587 $\mathrm{CCCN}$ ). En esas circunstancias, las integra a su propio derecho de defensa, las esgrimirá "en su nombre personal" como medio de obstar al reclamo del acreedor. Por ende, tampoco aquí hay sustitución pues en realidad el fiador no está defendiendo un derecho ajeno sino uno propio. Parecida cosa ocurre con el acreedor prendario que puede ejercitar todas las acciones del deudor-propietario para reclamar la prenda o defenderla de terceros, (ver por ejemplo, art.1869 segunda parte, Cód. Civil español).

Micheli sostiene que el obrar del sustituto no excluye la presencia del sustituido como parte en el proceso. El autor hace mención a los casos de los arts 184 y 2900 última parte Cód.Civil italiano, relativos respectivamente, al consenso conyugal para la enajenación de ciertos bienes y a la acción subrogatoria ${ }^{46}$. Llevados a nuestro derecho, vemos que el primer caso se corresponde con lo dispuesto por el art.1277 Cód.Civil (art. 456,458 y 462 CCCN). Entendemos que el cónyuge que opera sin el consentimiento del otro o la autorización judicial supletoria, carece por ese motivo del derecho a sustituirlo y su actuación en tal sentido resulta inválida. Si se presenta el esposo faltante, cada uno estará ejerciendo su propio derecho sustancial sobre los bienes sin que se pueda advertir sustituciones recíprocas. En cuanto al acreedor subrogante, el sistema de convocatoria a juicio previsto por los arts.114 CPCCN y 740 CCCN, tal como la parte final del art.2900 Cód. Civil de Italia, apunta

\footnotetext{
${ }^{46}$ Micheli Gian Antonio.Obra citada, pgs 210 y 211
} 
precisamente a la exclusión del subrogante sustituto apenas se presente el subrogado. Es cierto que aquél puede seguir como coadyuvante simple, al igual que el adquirente del art.44 CPCCN, pero esa no es ya una función sustitutiva, sino, precisamente coadyuvatoria y además, subordinada.

b) Critica. Aun desbrozado el campo de los ejemplos, si como dice Guasp la clave está en el reconocimiento de legitimación para todo el que defiende un derecho u obligación ajena, podrían entrar en la categoría de sustitutos los que de distintas maneras y con diversos propósitos, pueden producir efectos defensivos en derechos de otro (por ejemplo, los intervinientes litisconsorciales adhesivos, los coadyuvantes simples, los intervinientes no voluntarios, los litisconsortes necesarios). $\mathrm{Si}$ como sostiene Palacio lo definitorio es la existencia de una obligación de garantía, no vemos que pueda encontrársela en cabeza de ninguna de las partes en la acción subrogatoria, un indiscutido caso de sustitución y en donde ni subrogado ni subrogante se garantizaron ni se garantizan. La existencia de un interés propio en la defensa de un derecho ajeno tampoco puede llevarnos a conclusiones que den a la sustitución una inusitada amplitud: en efecto, por ejemplo, los coadyuvantes simples y los intervinientes obligados se mueven en virtud de aquella modalidad de interés y, claramente, no son sustitutos.

c) Opinión propia. En tren de buscar una delimitación adecuada al instituto, tarea no muy fácil por cierto, es necesario comenzar por recordar el significado del verbo y de la acción de sustituir: sustituir es reemplazar, ocupar el lugar de pertenencia de otra entidad. Sustituir procesalmente es suplantar a otro sujeto, a título propio y en calidad de parte, es decir actuar en el mismo rol del sustituido. La lógica consecuencia de la sustitución es la exclusión del sustituido del papel que asume el sustituto ya que la 
permanencia de ambos generaría una situación de incompatibilidad de funciones y de definiciones de predominio que por sí, mostrarían la inutilidad de la presencia conjunta ${ }^{47}$.

En conclusión, sostenemos que en la sustitución lo definitorio es la ausencia del sustituido en la función defensiva del derecho en litigio, de donde concluimos que habrá sustitución únicamente cuando aquél, sin quedar desvinculado de la cosa juzgada ni perder su condición de parte subyacente, es excluido totalmente de la posibilidad de defender por sí, y como parte principal el derecho sustancial del que es titular, el que pasa a ejercerse por quien tenga derecho o deber de sustituir. La existencia de ese derecho no impide que según el caso, el sustituido pueda reasumir transitoriamente o de manera definitiva su natural papel de autodefensa o coadyuvar con la que lleve adelante el sustituto.

d) Clases. Según nuestro criterio y conforme el derecho argentino, la sustitución se produce solamente en los casos que especificaremos determinados por ley (como derecho o como deber) o por acuerdo. Por ley en la acción subrogatoria, en la enajenación de la cosa litigiosa y en la

\footnotetext{
${ }^{47}$ La exclusión referida no puede desvincular al sustituido, verdadero titular del derecho sustancial jugado en el litigio, que pasa entonces a ser una parte subyacente sometida por ende a la cosa juzgada que se obtenga; ello indica que el sustituto no hace más que asumir para sí la defensa en juicio de tal derecho, justificado por ser titular de algún derecho u obligación sustancial que le permite o le fuerza a hacerlo, o bien por una especial convención lograda entre los litigantes originarios. Asumirá en calidad de parte $\mathrm{y}$ con todas las prerrogativas y cargas que importa esa condición. Es claro que el sustituto obra por sí, a título propio, sin relación de dependencia o de representación con respecto al sustituido y conforme su propio criterio, asumiendo por ende la correspondiente responsabilidad.
} 
asunción total de defensa en la evicción. Con respecto al seguro ver punto $38)^{48}$.

La sustitución subrogatoria, se ejerce por derecho del subrogante, en la acción de los arts.1196 Cód.Civil ( 739 CCCN )y de los arts.113(111) a 116(114) CPCCN ; la cosa juzgada que se logre, alcanza también al subrogado (art.116(114) CPCCN) que puede desplazar al subrogante y recuperar en cualquier momento su papel de parte principal reasumiendo la defensa de su derecho en litigo (art.115(113) CPCCN) y relegando al subrogante al rol de tercero coadyuvante simple. Sin embargo, vemos que según el art. 114(112) CPCCN el ingreso tardío del subrogado convierte al subrogante en litisconsorte del primero (art.92(90) segunda parte y 93(91) parte final $\mathrm{CPCCN}$ ) con sus mismas facultades procesales es decir que operará como parte principal no obstante que la posición del subrogado en el derecho sustancial no ha variado, al punto que deba reconocer documentos y absolver posiciones. No se explica como el subrogante puede quedar en aquella condición cuando quien la reúne no es él sino el subrogado que llega, y, sobre todo si se piensa que ese subrogante ante la presentación del subrogado al inicio del proceso, no hubiera sido sino coadyuvante simple; además que no tendrá la calidad del art.92(90) inc. $2^{\circ}$ CPCCN pues nunca estuvo en condiciones sustanciales de demandar o ser demandado por sí mismo, sino como subrogante. Creemos entonces que el dispositivo que criticamos, debe ser entendido como arbitrio para dejar en claro que el titular sustancial que fuera subrogado, al presentarse, no queda como coadyuvante simple sino en categoría de principalidad pero como

\footnotetext{
${ }^{48}$ Palacio sostiene la existencia de diversas clases de sustitución de las que destacamos la total y la parcial ejemplificada en la coadyuvación simple del art.112, ap. $2^{\circ} \mathrm{CPCCN}$, o en la evicción en calidad litisconsorcial del art.109 CPCCN respectivamente (Palacio Lino E. Derecho...citado,,T.III, pg. 290.
} 
adherente a la posición tomada inicialmente por el subrogante, cosa de dejar así preservado el thema decidendi. En cambio, no se está definiendo el rol que paralelamente continúa operando el subrogante y que no puede ser distinto del fijado por el art.115(113) primera parte CPCCN sin perjuicio de sus derechos como acreedor (por ejemplo, acción pauliana).

La sustitución por enajenación de la cosa litigiosa se lleva a cabo por deber, cuando quien quedó sometido a la jurisdicción y a su vocatio, luego de demandar o ser demandado, tiene que permanecer en el juicio como parte con todas las cargas inherentes no obstante haberse desprendido del derecho sustancial por el cual se encontraba litigando. Es el caso del art.44 CPCCN configurativo de la sucesión sustancial entre vivos-sin sucesión procesal- y en el que la cosa juzgada alcanza al enajenante frente al adversario, en tanto que también hará lo propio con el adquirente que estuviese conciente del estado litigioso, que como sucesor, no puede recibir un derecho mejor (o peor) que el transmitido .Por su parte, el adquirente puede participar del juicio pero en la calidad prevista por el art.92(90) inc. $1^{\circ}$ y 93 primera parte CPCCN. Ver sobre el tema punto 12.d.

La sustitución convencional se produce cuando el garante conviene con la contraparte liberar al garantizado del ejercicio de la defensa de su derecho, cosa que no importa excluirlo de los efectos de cosa juzgada frente al actor que producirá la sentencia ${ }^{49}$. No está prevista de esa manera

\footnotetext{
${ }^{49}$ La sustitución convencional está prevista en el art.108 del CPC italiano, para los casos en los que el fiador del demandado convenga con el afianzado "asumir la causa" en lugar del segundo con la conformidad del acreedor para la extromisión correspondiente; la ley prevé que el extromitido, no obstante dejar el pleito, será alcanzado por todos los efectos de la cosa juzgada que se produzca, es decir que el sistema no altera la relación sustancial entre acreedor y deudor pues de lo contrario, la sentencia no tendría porqué afectarlo. Aquí el extromitido queda vinculado al pleito al punto tal que puede ser llamado a absolver posiciones o a reconocer documentos.
} 
en el derecho argentino, pero su equivalente aproximado estará dado por la asunción de defensa por parte del garante de evicción, tema que encararemos enseguida.

Pensamos que, contrariamente a lo habitualmente sostenido por la doctrina, no hay sustitución en la garantía de evicción en tanto el garantizado opere defendiendo su derecho sin dejarlo en manos del garante. En cambio, la presencia del garante asumiendo exclusivamente la defensa del garantizado importa un caso de sustitución con extromisión (al respecto, nos remitimos a lo expuesto en el punto 39.d), que de todos modos tampoco libera al segundo como parte subyacente-no se desprendió del derecho sustancial-, y lo deja sometido a la cosa juzgada. La sustitución por evicción, supone un supuesto distinto e inverso del que resulta del mismo art.44 CPCCN cuando al ser extromitido con la conformidad del contrario ,el enajenante que ya había dejado su condición de titular de la relación jurídica sustancial, hace lo propio con la de parte, quedando por ende totalmente desvinculado del proceso y liberado de toda carga, inclusive la de absolver posiciones ya que ellas solo pesan sobre las partes ${ }^{50}$ y su lugar es ocupado por el adquirente que pasará a defender su derecho por sí mismo.

Desde ya que no habrá sustitución en la delegación de deudas con la conformidad del acreedor, (cesión de deudas, art.1632 CCCN) pues en tal supuesto quien asume el crédito no será sustituto sino que defenderá su derecho propio. Menos lo es con relación a la delegación imperfecta de deudas, en la que el anterior y el nuevo deudor también pasarían a litigar por sus derechos sin convertirse en sustitutos (recordar sin embargo la

\footnotetext{
${ }^{50}$ Puede verse al respecto, nuestra posición en Rivas Adolfo A. Obra citada,T.1, pgs 247 a 250)
} 
solución del art.1633 CCCN que no acepta la asunción de deuda si el acreedor rechaza la liberación del deudor ).

\section{Coadyuvación y sustitución}

Chiovenda ya señaló la afinidad existente entre la coadyuvación y la sustitución ${ }^{51}$ opinión que, desde ya, nos anticipa la existencia de contenidos comunes que señalaremos al tiempo que trataremos de mostrar diferencias. Para ese fin cotejaremos la sustitución con la coadyuvación que denominamos propia ya que la impropia, por definición y contenido, excluye que el coadyuvante se encuentre actuando en tarea sustitutiva.

Veamos entonces: en ninguna de esas figuras hay representación; por ende, ni coadyuvante ni sustituto obran a nombre del coadyuvado o del sustituido sino a título propio. En ambas, coadyuvante y sustituto asumen la defensa de un derecho del que no son titulares sustanciales. Ninguno de los dos, adquiere la titularidad de tal derecho ni la posibilidad de llevar a cabo actos procesales o de disposición que por su naturaleza sean propios y exclusivos del sustituido. Además, caen bajo el efecto de la misma cosa juzgada que afecta a sustituido (art.116(114) CPCCN) y coadyuvado respectivamente (art. 96(94) CPCCN), si bien con el alcance relativo a sus diferentes legitimaciones ${ }^{52}$.

${ }^{51}$ Chiovenda Giuseppe .Obra citada, T.2.I, pg.32

${ }^{52}$ Kenny entiende que en el caso de evicción , ante la ausencia del garante o ante su presencia con negativa a ejercer la defensa, no es aplicable el art. 96 mencionado en cuanto al efecto de cosa juzgada ( Kenny Héctor Eduardo, obra citada..pg.54) Pensamos que si así fuera, la última parte del art.108 CPCCN dejaría sin sentido la citación 
No obstante ello, coadyuvación y sustitución son figuras distintas: es fundamental tener en cuenta que en ningún caso el coadyuvante tiene derecho o deber legal-sustancial o procesal- de desplazar al coadyuvado ocupando su lugar para o ejercer en exclusividad el derecho de defensa del derecho en torno del cual se litiga; por el contrario, necesita de la presencia en juicio del coadyuvado para producir la propia, de modo que no puede tomar la iniciativa de coadyuvar sin aquélla. La sustitución, en tanto, no precisa de tal presencia y a la inversa del caso anterior, su ausencia es la que la justifica; así ocurre en la acción subrogatoria, en el caso del art. 44 CPCCN y con más razón en la sustitución con la conformidad expresa de la contraparte para la salida del sustituido.

\section{Tipos de intervención voluntaria}

a) Introducción. Conforme el CPCCN la intervención voluntaria o adhesiva puede a) ser calificada o litisconsorcial- posible generadora de coadyuvación por consecuencia-b) no calificada o de coadyuvación simple y propia que puede dividirse en genérica y específica y esta última en derivada por subrogación y derivada por adquisición; a primera es la de los art.92(90) inc. $1^{\circ}$ y 93 primera parte CPCCN. La derivada por subrogación, proviene, precisamente, del instituto subrogatorio de los arts.1198 Cód. Civil y 739 CCCN, recogido en el CPCCN por los arts.114(112) y 115(113). La derivada por adquisición es la que deviene para el comprador

misma, que es, precisamente, crear el presupuesto necesario para poder operar la acción de regreso. 
del bien objeto del litigio (art.44 $\mathrm{CPCCN}$ ) cuando el enajenante no es extromitido ${ }^{53}$.

b) Intervención voluntaria calificada o litisconsorcial. Es la del que voluntariamente requiere su admisión por estar legitimado según las normas del derecho sustancial para ser demandante o demandado en el proceso del que se trate. Ello significa que deberá sustentar un grado de titularidad activa o pasiva del derecho en discusión que le hubiera permitido operar con aquellos roles, en ambos casos con calidad de litisconsorte facultativo según el art.92(90) CPCCN; por ejemplo, es lo que puede ocurrir en caso de cotitularidad de bienes, de obligaciones solidarias y en todo supuesto de pluralidad de sujetos de una relación jurídica sustancial, o de distintas legitimaciones habilitadas para defender un mismo derecho, salvo que corresponda la necesidad de constituir litisconsorcio según las previsiones del art.91(89) CPCCN. Así las cosas, la sentencia que se dicte, involucrará el derecho del interviniente frente a la contraparte del adherido.

A partir del vínculo generado por la adhesión, que le fuerza a respetar el thema decidendi planteado por las partes originarias y coincidir básicamente con el adherido sin poder retrotraer el pleito, el ingresante podrá actuar con total autonomía con respecto al sujeto al que acompaña. Aquella titularidad le asegura su condición de parte con legitimación plena, tal como le reconoce expresamente el derecho positivo ${ }^{54}$. Así, hasta podría -de

\footnotetext{
${ }^{53}$ Otra categoría voluntaria es la que conforma la intervención excluyente, prevista expresamente en las codificaciones de Córdoba, Jujuy, La Rioja, Mendoza, Santa Fe y Tierra del Fuego en la que no nos detendremos. Ver nuestra posición fijada en el punto 49 acerca de la denuncia de litis excluyente en el CPCCN.

${ }^{54}$ Arts,92 CPCCN; 82 CPC Jujuy, 48 CPC Brasil, 45 segundo párrafo CGP Uruguay. La doctrina germana acepta que lo sea como litisconsorte del adherido-así se refleja en el pgfo 69 ZPO no obstante que no por ello deja de ser adhesivo. En coincidencia, arts.
} 
acuerdo al momento de su ingreso- reconvenir (art.358(357) segunda parte CPCCN) o sumar litis por acumulación de procesos y hasta en su actuación ulterior, contradecir al sujeto al que adhirió. Tal como lo señalamos, el sujeto al que nos referimos, desde el momento en que asume como parte veda todo rol tercerista.

c) Intervención voluntaria no calificada genérica. El coadyuvante del art.92(90) inc.1 CPCCN, se ve limitado, como regla básica, a actuar en coincidencia y no en oposición con el sujeto al que adhirió, ya que lo contrario importaría negar su propio interés en participar en ese juicio. En efecto, si ingresa no es por estar obligado a ello pues su derecho no está en juego directamente, sino porque hace a su conveniencia defender el derecho del adherido con lo que satisface su propio interés.

La figura que referimos refleja a través de su tratamiento por la doctrina y su recepción normativa, las dificultades existentes para establecer la naturaleza jurídica de su presencia y admisión en un pleito ajeno. En efecto, pese a aceptarse su derecho al proveimiento y el peso de la cosa juzgada, no se le consideró parte y para justificar su admisión y permanencia, se dijo que se trataba de un procurador en su propio interés, o de un asistente, o de un interviniente, o de un contradictor agregado. También, integrándolo en una solo persona con el coadyuvado ${ }^{\mathbf{5 5}}$-con lo cual ya se le está reconociendo como parte- ,hasta llegar por fin al CPCCN que así considera a los dos intervinientes referidos por el art.92(90).Con ello la ley nacional, a nuestro juicio, admite implícitamente que el coadyuvante simple es también titular de pretensión o defensa específica

90 CPCCN,111 CPC Mendoza ,302 CPC Santa Fé, 54 CPC Brasil, art.62 CPC Colombia, 381 CPC Venezuela, 48.2 CGP Uruguay

${ }^{55}$ CGP.Tierra del Fuego (art.102), CPC Paraguay (art.78) y CGP Uruguay ( art.334.2 
consistente en requerir el triunfo del adherido y así, acepta como parte-si bien con una legitimación acotada- a quien postula un nuevo y distinto género procesal derivado no de una demanda o de una contestación defensiva originaria, sino de un "acto de intervención" al decir de $\mathrm{Wach}^{\mathbf{5 6}}$. Hasta sostuvimos-quizá en soledad-que en tanto su suerte era común con la del coadyuvado conformaba con éste un litisconsorcio sui géneris apuntado a obtener el triunfo frente a la contraparte aunque ello no definiera de por sí la relación sustancial entre coadyuvante y coadyuvado ${ }^{57}$.

El coadyuvante simple, como todo coadyuvante, no representa al coadyuvado ni obra según sus instrucciones o autorización y por tanto, goza de libre albedrío para su autoconducción ; ello empalma con el uso o sometimiento en igual intensidad y esencia, de todos los derechos y cargas inherentes a la condición de parte, campo en el que no se visualiza la posibilidad de establecer diferenciaciones con los que son reconocidos como sujetos principales ${ }^{58}$. No pasa lo mismo con la libertad de gestión ya que la validez de los actos del coadyuvante simple queda condicionada a los limites precisados por el art.92(90) primera parte CPCCN, y si bien vemos que el coadyuvante simple no debe requerir autorización del coadyuvado para conducirse en el proceso, sus postulaciones pueden no

\footnotetext{
${ }^{56}$ Wach Adolf. Manual de Derecho Procesal Civil,pg 459.(Traducción del alemán de la obra Handuch des Deustchen Civil Prozessrechts,t. I,Leipsig.1885).por Tomás

A.Banzhaf. .EJEA.Buenos Aires.1977

${ }^{57}$ Rivas Adolfo A. Obra citada,T.II,pgs.22 a 25. Advertimos sin embargo que Arazi dice en su trabajo,"El tercero adherente simple",LL 1995-C-442, si bien sin agregar fundamento, que el coadyuvante simple es litisconsorte.Es claro que el interviniente no calificado no es un litisconsorte la manera del sujeto del art.90 inc.2 CPCCN, pero se "asocia" al coadyuvado y se somete a su suerte hasta la confluencia de su interés.

${ }^{58}$ Arts.303 último párrafo CPCC Santa Fe,52 CPC Brasil, 97 tercera parte CPC Perú, 380 CPC Venezuela
} 
resultar trascendentes o ser realmente inválidas, si quisiera oponerse al adherido al que le está subordinado o exceder los límites de actuación que a éste corresponden frente a la contraparte, pues, como bien lo indica la ley no puede alegar ni probar aquello que no puede alegar ni probar el coadyuvado. La afectación referida puede dar lugar a la intervención genérica-sin un propósito preidentificado por la ley- o a la intervención derivada - con un objetivo específico previsto en la norma-, que a la vez puede ser derivada por subrogación o derivada por enajenación de objeto litigioso.

\section{d).La intervención voluntaria no calificada por derivación}

subrogatoria. Si el subrogado deja su pasividad y demanda el cobro del crédito o demuestra que ya lo está reclamando en juicio, el subrogante pierde su derecho y solamente le queda un papel complementario y/o de control de la actividad del titular de modo tal que el art.114(112) segunda parte CPCCN, le permite actuar como un codyuvante simple art.92(90) inc. $1^{\circ} \mathrm{CPCCN}$ es decir con una actividad subordinada que sin embargo, no le impedirá como acreedor, utilizar en su caso, la acción pauliana y alegar la prescripción renunciada por su deudor (arts.3963 Cód.Civil y 2534 segunda parte $\mathrm{CCCN}$ ). Sobre su posible actuación litisconsorcial ver punto 11.

e)Intervención no calificada por adquisición de objeto litigioso. La intervención voluntaria no calificada por adquisición de objeto litigioso, es la prevista en la última parte del art.44 $\mathrm{CPCCN}$, regulatorio de los efectos procesales de la sucesión sustancial por actos entre vivos y que tiene como hipótesis de aplicación la transferencia de titularidad del bien involucrado o la cesión del derecho discutido en un juicio abierto. Dicha transferencia puede o no ir acompañada de la correspondiente sucesión procesal. Se 
producirá si la contraparte acepta el ingreso del adquirente con el paralelo desplazamiento del enajenante, caso en el que coincidirán ambos tipos de sucesiones. De no darse tal aceptación, el enajenante deberá seguir en el pleito produciéndose entonces un caso de sustitución procesal- tal como lo vimos- $\mathrm{y}$ al adquirente solamente se le admite en un papel subordinado, es decir como coadyuvante simple ${ }^{59}$.

\section{La intervención coactiva}

\footnotetext{
${ }^{59}$ Art.44 CPCCN: Sustitución de parte. Si durante la tramitación del proceso una de las partes enajenare el bien objeto del litigio o cediera el derecho reclamado, el adquirente no podrá intervenir en él como parte principal sin la conformidad expresa del adversario. Podrá hacerlo en la calidad prevista por los arts 90 , inc .1) y 91, primer párrafo" Parecida redacción encontramos en el art.56 CPC Jujuy, y si bien literalmente distinto, tiene el mismo sentido el art.28 CPCC Santa Fe. Con mayor claridad, el CPC de Mendoza, art.24, advierte que en caso de sucesión a título singular el adquirente tiene opción para concurrir al proceso como litigante principal o como tercerista coadyuvante del cedente. Si toma el primer temperamento, precisa la conformidad de la contraria, pero si se la obtiene, el enajenante pierde principalidad y pasa a actuar como coadyuvante del cesionario. Si sigue el segundo camino comparece como coadyuvante del cedente y no como principal. Igual solución contiene el art.24 del Proyecto de Código Procesal Civil de la Nación de 1949 de la autoría de Podetti. Pese a la titularidad sustancial que ostenta el adquirente, se advierte que si al tiempo de constituirse el proceso no se había producido la enajenación, carecía obviamente de la posibilidad de ser parte originaria, y tampoco podía ingresar voluntariamente como tercero en los términos de los arts. 92 inc. $2^{\circ}$ y 93 segunda parte CPCCN pues ellos están referidos a quienes pudieron ser actores o demandados en aquéllos momentos y no $a$ posteriori. En esas condiciones, la ley procesal nacional considera que el derecho del adquirente está a resguardo por la presencia del enajenante como antecesor sustancial (y las responsabilidades que le pudieren caber) y por la calidad de coadyuvante simple que se le reconoce para ingresar voluntariamente en el pleito si resulta de su interés, habilitándole así para cubrir los defectos defensivos en los que el antecesor pudiera incurrir.
} 
Tal como se señalara en el punto 1 , se arriba al proceso de manera voluntaria o coactiva. La coactividad tiene como presupuesto la citación o la notificación judicial de la existencia de un proceso en el que el sujeto que la recibe tendrá que jugar su rol de actor o demandado, o de tercero.

Si fuera los dos primeros, podría tratarse del llamado al litisconorte necesario ausente; si lo fuera exclusivamente del segundo, estaríamos en el campo de la notificación de la demanda. En todos ellos, la coerción deriva de la posibilidad de sufrir las consecuencias negativas significadas por una declaración de rebeldía y de no obstante quedar en esa situación, ser alcanzado por la cosa juzgada resultante.

En materia de terceros recordaremos que la intervención obligada es la única tercería coactiva, ya que las intervención del coadyuvante simple es voluntaria. Según se verá no es entonces utilizable el sistema de la contumacia ,y el interviniente decidirá operar o abstenerse apreciándola perspectiva de la inexorable aplicación de la cosa juzgada. 


\title{
CAPITULO SEGUNDO
}

\section{LA INTERVENCION OBLIGADA DE TERCEROS}

\author{
SECCION PRIMERA
}

APROXIMACION A LA INTERVENCION OBLIGADA

\section{Denominación}

Considerando la intervención obligada de terceros con una visión global, podemos decir que es una modalidad de advenimiento $y$ participación coactiva de terceros coadyuvantes o no, derivada, en el derecho argentino de la iniciativa de una de las partes. En algunos sistemas extranjeros y en el de La Rioja igualmente por la del oficio judicial.

Es también denominada por la doctrina como intervención "coactiva"," provocada"," forzosa". Reservamos la primera para otorgarle un sentido genérico, tal como se expresa en el punto 13, pues como lo dijimos nos sirve para identificar distintas situaciones de acceso no voluntario. Descartamos también la de forzosa, por tratarse de una calificación que atribuimos a la participación de los demandados ante la notificación, calidad naturalmente distinta de la de terceros. Consideramos que la provocación permitiría suponer que solamente si hay reacción del citado habría intervención obligada y no en caso contrario. De tal manera, 
recurriremos a la última, "intervención obligada" no solo porque es la utilizada por el CPCCN sino porque es la que mejor se ajusta al ineludible efecto de cosa juzgada que se ha de producir sobre el citado, concurra o no materialmente al proceso.

Teniendo lo expresado como punto de partida, comenzaremos por intentar una corta reseña histórica de la intervención obligada de terceros, para luego repasar tanto el derecho positivo como la doctrina de los países que elegimos para nuestro estudio, como similar tarea con respecto al derecho argentino.

\section{Breve reseña histórica}

La intervención obligada de terceros hunde sus raíces en el derecho romano no obstante el principio de singularidad que caracteriza al proceso en tal sistema. Así se la encuentra en la evicción y también para el caso de convocarse al verdadero titular cuando el tenedor de un bien era demandado por reivindicación. Ambas situaciones generaban la invitación al tercero conocida como laudatio o nominatio autoris, denominación que posteriormente quedaría reservada al segundo de los supuestos referidos ${ }^{\mathbf{6 0}}$. Wach resalta las fuentes romanas pero recuerda también las del derecho germánico en el que se dan los gewere, formaciones de garantía convencional que obligaban al vendedor a asumir la defensa del comprador, ,ocupar su lugar frente al demandante y eventualmente a

\footnotetext{
${ }^{60}$ Alvarez Urcisino. Curso de Derecho Romano,t.I,pgs 215 y 216. Revista de Derecho Privado. Madrid. 1955
} 
indemnizarlo ,y que fueron dejándose de lado al evolucionarse hacia un reconocimiento pleno a la capacidad de autodefensa del adquirente ${ }^{61}$.

También con origen en el derecho germánico, se encuentra la adcitatio,forma convencional con la que el enajenante garantizaba al adquirente ante posibles reclamos judiciales de terceros en materia de enajenaciones de fundos y beneficios eclesiásticos. La adcitatio es tomada luego por el Derecho Canónico en el que se lo utilizó con mayor amplitud, abarcándose prácticamente -en homenaje al principio de continencia de la causa- a todo supuesto en el que terceros pudieran plantear reclamos sobre el derecho a resarcimiento por la promesa o la actividad de otro. Esa institución se trasladó al derecho germano-tradicionalmente recostado en el principio de universalidad del proceso-y al de Francia ${ }^{62}$. Pero más tarde se abandonó en el primero de esos países con la sanción de la ZPO que se inclina por descalificar a la adcitatio y solamente acepta el llamamiento a terceros en base a la litisdenutiatio o denuncia de litis. En cambio, la adcitatio es recibida en Italia y recogida en el actual CPC italiano bajo las formas de llamamiento en causa y citación en garantía ${ }^{63}$ que ya consideramos.

En materia de terceros, las leyes de enjuiciamiento español de 1855 y 1881 no contienen otras disposiciones que no fueran las referidas a las tercerías de dominio y de mejor derecho, en tanto la evicción aparece tratada en el Código Civil.

\footnotetext{
${ }^{61}$ Wach Adolf. Obra citada. V.II, pg 467

${ }^{62}$ López Fragoso Tomás. La intervención de terceros a instancia de parte en el proceso civil español, pgs. 22 y 23.Marcial Pons Ed. Jurídicas .S.A. Madrid.1990,

${ }^{63}$ López Fragoso Tomás. Obra citada, pg 24.
} 


\section{SECCION SEGUNDA}

DERECHO EUROPEO

\section{Noticia introductoria}

El derecho procesal argentino se ha ido formando a la luz de la evolución del derecho europeo; parece entonces que no podemos introducirnos en el estudio de la intervención obligada de terceros y sus consecuencias según las previsiones del CPCCN y sus seguidores- así como la de los códigos provinciales que le sirvieron de modelos- sin internarnos en la formación de dicho instituto en la legislación y la doctrina continental.

En esa tarea recurriremos al análisis-breve por cierto- de los dos sistemas jurídicos que mayor trascendencia han tenido sobre el derecho procesal moderno (los de Alemania e Italia) para luego ir al estudio del español-de indudable peso en nuestro derecho procesal en sus primeras etapas.

\section{Alemania}

La Ordenanza Procesal Civil (ZPO), data de 1877 habiéndosele introducido diversas modificaciones .El material que nos interesa destacar de tal ordenamiento, se encuentra en el Libro Primero, Sección Segunda, el Título II " Litisconsorcio" -pgfs 59 a 63-y título III "Intervención de 
terceros en el proceso" -pgfo 64 hasta el pgfo 77-. Comprende la intervención principal -pgfo 64-, la voluntaria adhesiva-pgfo.66-, la adhesiva contenciosa-pgfo 69- y la principal (tercero pretendiente)-pgfo 75-de la versión que encontramos en Goldschmidt y a la que nos remitimos 64.

${ }^{64}$ Goldschmidt James.Derecho Procesal Civil..Traducción de la segunda edición alemana y del Código Procesal Civil, incluído como apéndice por Leonardo Prieto Castro.Editorial Labor S.A.Barcelona-Buenos Aires-Río de Janeiro.1936e

Pgfo 59.Podrán varias personas demandar o ser demandadas conjuntamente como litisconsortes siempre que se hallen en estado de comunidad jurídica con respecto al objeto litigioso o tengan un derecho o se encuentren obligados por la misma causa de hecho o jurídica.

Pgfo 60.Podrán varias personas también demandar o ser demandadas conjuntamente como litisconsortes cuando el objeto del litigio esté constituido por derechos u obligaciones de la misma clase basados en causas de hecho y jurídicas homogéneas en lo esencial.

Pgfo.61.Los litisconsorte se considerarán en sus relaciones con la parte contraria y mientras no resulte otra cosa de los preceptos del derecho civil o los de esta Ley, como litigantes separados, de manera que los actos de cada litisconsorte no redundarán en provecho ni en perjuicio de los demás.

Pgfo 62.Cuando la relación jurídica litigiosa haya de ser resuelta de modo uniforme para todos los litisconsortes o cuando el litisconsorcio sea necesario por cualquier otra causa ,los litisconsortes contumaces en algún término o que dejen transcurrir algún plazo se considerarán representados por los comparecientes.

Los litisconsortes contumaces deberán ser llamados para que intervengan en las actuaciones subsiguientes.

Pgfo 63.El derecho de impulsar el procedimiento corresponde a todos los litisconsortes; cuando uno de ellos cite a la parte contraria para alguna actuación, deberán citar también a sus colitigantes.

Pgfo 64.El que pretenda tener derecho sobre la totalidad o parte de la cosa o derecho sobre el que haya trabado pleito entre otras personas puede ,hasta el momento de la resolución del mismo ,hacer valer su derecho ante el Tribunal en que haya pendido el negocio en primer instancia, por medio de demanda dirigida a las dos partes contendientes. 
Pgfo 65.El proceso principal puede suspenderse mientras se resuelve sobe la intervención principal, a petición de alguna de las partes.

Pgfo 66.Quien tenga interés en que en un proceso pendiente entre otras personas venza una de las partes, puede intervenir en la causa con el fin de ayudar a la misma.

La intervención adhesiva puede tener lugar en cualquier estado de la causa hasta las resolución de la misma por sentencia firme, incluso en la interposición de algún recurso.

Pgfo 67.El interviniente tiene que aceptar la causa en el estado en que se halle al intervenir en la misma. Está autorizado para ejercitar medios de ataque y de defensa y para ejecutar válidamente toda clase de actos procesales, en tanto sus actos $\mathrm{y}$ declaraciones no estén en oposición con los de la parte principal.

Pgfo 68. El interviniente adhesivo, para los efectos de su relación con la parte principal, no será oído con la afirmación de que la causa, tal como le ha sido presentada al juez, ha sido resuelta con error; solo será oído si afirma que la parte principal ha llevado la causa, cuando por el estado de la misma al tiempo de su entrada en ella o por las manifestaciones y actos de la parte principal, haya estado impedido de ejercitar medios de ataque y de defensa, o cuando la parte principal, intencionadamente o por negligencia grave, no haya hecho uso de medios de ataque y de defensa que él no conocía.

Pgfo 69. Cuando, según los preceptos del Derecho Civil, la sentencia firme del proceso principal haya de producir efectos en la relación jurídica del interviniente adhesivo con la parte contraria, el interviniente adhesivo, será considerado litisconsorte de la parte principal, a tenor del pgfo 61 .

Pgfo 72" .Toda parte de un proceso que, en caso de resolverse éste en perjuicio de ella, crea que pueda ejercer una acción de garantía o de repetición contra un tercero, o que actúe cuidando del derecho de un tercero, puede denunciar judicialmente al tercero la pendencia la causa, hasta el momento de la resolución firme de la misma

El tercero puede, a su vez, denunciar la causa a otra persona.

Pgfo 73"La denuncia del litigio se hará por medio de escrito notificando al tercero, en el cual se indicará el motivo de la denuncia y el estado de la causa”. 
De ese escrito se pasará una copia a la parte contraria.

Pgfo 74."Si el tercero entra en la causa con el litis denunciante, su relación con respecto a las partes se regirá por los preceptos reguladores de la intervención adhesiva".

Si el tercero se niega a intervenir o no hace ninguna manifestación la causa seguirá su curso sin él"

"En todos los casos enunciados en este parágrafo se aplicarán contra el tercero los preceptos del 68, pero en vez de atenderse al tiempo de la intervención se tendrá en cuenta aquel en que fuera posible la intervención por efecto de la denuncia."

Pgfo 75:" Si el deudor demandado denuncia la pendencia de la causa a un tercero que pretenda para sí el crédito reclamado y éste interviene en la misma, puede ser desligado de la causa a petición suya con tal que consigne el importe de la reclamación a favor de los acreedores litigantes, renunciando al derecho a la devolución. El deudor será condenado en tal caso al pago de las costas que se hayan causado por su resistencia infundada a satisfacer la deuda, y la causa continuará entre los acreedores para determinar a cuál de ellos pertenece el derecho. Se fallará la entrega de la suma depositada al vencedor, y el vencido será condenado a satisfacer todas las costas, comprendidas las causadas por el deudor, no producidas por su resistencia infundada, y los gastos del depósito".

Pgfo 76."'La persona demandada como poseedor de una cosa que afirme poseer por razón de una de las relaciones jurídicas mencionadas en el pgfo 868 del Código Civil, podrá denunciar la causa al poseedor mediato antes de que se entre en el fondo de la misma y citarle para que comparezca, al mismo tiempo que pone en conocimiento del demandante la denuncia hecha, con el efecto de que puede negarse a intervenir en el fondo del negocio hasta tanto no comparezca el denunciado o no haya transcurrido el termino en el que deba comparecer"

"Si el llamado discute la afirmación del demandado o no hace manifestación alguna, el demandante está autorizado para acceder a la pretensión de la demanda" 
Comenzaremos recordando la doctrina elaborada por Wach en materia intervención de terceros. Con respecto al interviniente adherente voluntario, pese a que sostiene la existencia de un derecho a intervenir en base a su interés jurídico según lo establece el pgfo 63 de su versión.(pgfo 66 de la nuestra), es terminante al afirmar que aquél sujeto no es parte ni tampoco es litisconsorte, ni es significativo catalogarlo como parte accesoria. El objeto litigioso no es su derecho ${ }^{65} \mathrm{y}$ solo puede ser considerado como "un participante del proceso (socius), un asistente del litigante para su propio derecho, en nombre propio y por cuenta propia”. Nos explica que en el derecho común se entendía que el interviniente solamente puede beneficiar a la parte a la que adhiere, pero no perjudicarla, pero que a tal fin gozaba de independencia pues se consideraba que podía valerse de todos los medios de ataque y defensa incluso contra la voluntad del adherido sin que ello permitiera considerarlo litisconsorte sino

"Si el llamado reconoce como cierta la afirmación del demandado, queda autorizado, con el consentimiento de éste, para continuar la causa en su lugar. No será necesario entonces el consentimiento del demandado más que en el caso de que haga valer derechos que no dependan de que el demandado posea por efecto de una relación jurídica de la indicada en el apartado primero".

"Una vez que el llamado haya asumido el proceso, el demandado debe ,a petición suya ,ser desligado de la demanda. La resolución que recaiga será, por lo que atañe a la cosa litigiosa, válida y ejecutiva también contra el demandado."

pgfo 77."En el caso de que el propietario de una cosa o la persona a quien corresponda un derecho sobre una cosa interpongan demanda por daños en la propiedad o en el derecho, para que cesen éstos o no continúen; se aplicarán los preceptos del pgfo 76 si el demandado aduce que ha producido los daños en ejercicio del derecho de un tercero."

${ }^{65}$ Wach Adolf, obra y tomo citados,pg.408 y 410 
simplemente auxiliar. Ya en el siglo XIX pasó a entenderse que, como principio, carecía de tal independencia que conservaba solamente en los casos en los que la sentencia hiciere cosa juzgada en su contra. De tal manera, expresa que la regla de la ZPO es el principio de dependencia previsto en el pgfo 64 (pgfo 67 de la versión que tomamos) conforme el cual "el interviniente puede actuar eficazmente para la parte, con o sin la voluntad de ésta, pero no contra su voluntad expresa". ${ }^{66}$ No puede disponer ni modificar el objeto litigioso , ni reconvenir ,y la amplitud de medios utilizables que resulta de la letra del pgfo 64 (pgfo 67 de la versión que seguimos), debe ser de interpretación restrictiva ${ }^{67}$.Tampoco puede oponer excepciones procesales o materiales de tipo personal, "Su autonomía no es jurídico-material, sino procesal, porque el objeto litigioso es exclusivamente asunto de la parte" ${ }^{\% 68}$.El principio de independencia rige en cambio en los casos del pgfo 66 (69 de la versión que seguimos), pero igualmente le son aplicables las limitaciones mencionadas

En referencia al pgfo 65 (pgfo 61 de la versión utilizada) dice Wach que "regula únicamente la relación entre el interviniente y la parte principal, no su relación con la parte contraria. El interviniente solamente está obligado con respecto a la parte por la cual interviene por la sentencia dictada en el pleito entre ésta y la parte contraria, en cuanto deba reconocer su verdad" "99. Señala también que la ZPO, salvo el pgfo mencionado y otro referido a la substitución "no se ocupa directamente del efecto de la sentencia sobre la relación entre el interviniente y la parte contraria. Esto es

\footnotetext{
${ }^{66}$ Wach Adolf ,Obra y tomo citados,pgs 440 a 443 y cita en pg.443

${ }^{67}$ Wach Adolf ,Obra y tomo citados,pg 440

${ }^{68}$ Wach Adolf, Obra y tomo citados,pg 447.

${ }^{69}$ Wach Adolf, Obra y tomo citados, pgs 449 y 450
} 
una consecuencia de la naturaleza del asunto, pues una relación jurídica entre el adversario y el interviniente no es objeto de la resolución. Por otro lado no puede decirse que esa res aliena es res inter alios acta, ${ }^{\text {,70. }}$.

Particularizando ya en el interviniente referido por el pgfo 66 (69 de nuestro modelo) que parece atribuirle calidad litisconsorcial, afirma que "vale" como litisconsorte pero no lo es; sigue siendo interviniente adherente $^{71}$. El autor transcribe en el texto una versión del pgfo 66 -nuestro 69- en la que figura la palabra "vale", pero en la transcripción de la ZPO que figura como apéndice en ese libro, dice que "El que intervenga como auxiliar será considerado como litisconsorte" ,salvo que el interviniente sea parte desde el punto de vista material "cuando el objeto litigioso no solamente de la parte por la cual interviene sino también suyo y en realidad está legitimado para actuar activa o pasivamente en el juicio como parte y cuando la sentencia ,por razón de la tutela jurídica pretendida, solo podía ser unitaria habiendo un verdadero litisconsorcio (acumulación de acciones)" ${ }^{72}$. Los ejemplos que da y en los que es admisible concebir una formación litisconsorcial son los que hacen a objetos jurídicos indivisibles es representado en su totalidad por cada uno de los cotitulares del derecho o de la obligación. Así ocurre también, cuando el poseedor interviene por la persona que tiene la cosa en su nombre contra el demandante que acciona contra este último en calidad de tenedor (ZPO, pfgo 73)" o cuando el

\footnotetext{
${ }^{70}$ Wach Adolf ,Obra y tomo citados,pg.450

${ }^{71}$ Wach Adolf ,Obra y tomo citados,pg.450

${ }^{72}$ Wach Adolf, Obra y tomo citados, pg.458
} 
exequendus se adhiere al acreedor prendario o cuando intervienen varios acreedores prendarios" 73 .

"En todos estos casos, que son los que el pgfo 66 verdaderamente prevé, el interviniente está equiparado desde el punto de vista material a la "parte principal". La sentencia que se dicta a favor o en contra de ésta, afecta plenamente su propia relación jurídica con el adversario. El interviniente representa la causa, activa o pasivamente, en todo su alcance. La causa es la suya y por esa razón es correcto llamarlo, desde el punto de vista material, litisconsorte, y calificar su sucesión de comulación incidental. Pero tampoco entonces podrán dictarse resoluciones divergentes contra los distintos participantes como ya resulta forzosamente de la necesidad de que la declaración sea unitaria, y del hecho, de ahí derivado, de que mientras la causa sea defendida por la parte o el interviniente, no puede decirse que esté en estado para dictar sentencia y que pueda resolverse respecto de uno solo de los partícipes. Mientras no hayan sido vencidos todos ellos, el adversario no habrá triunfado y tan pronto como uno de ellos haya triunfado habrán triunfado todos" ${ }^{74}$. Afirma entonces que en todos los casos del pgfo 66 (pgfo 69 de nuestra versión) parte es aquel sujeto por el que se interviene, en tanto que el interviniente, es denominado por el propio dispositivo como interviniente por adhesión, que no interviene por demanda sino precisamente por un acto de intervención. "Su pretensión no se halla tampoco, propiamente hablando, en estado de litispendencia, porque no ha accionado. El sigue siendo, en el rubro del proceso, un interviniente adherente, y como tal es la calificación y trato que debe dársele desde el punto de vista de las formas procesales. De ahí se

\footnotetext{
${ }^{73}$ Wach Adolf.Obra citada, pgs. 458 y 459).

${ }^{74}$ Wach Adolf. Obra y tomo citados,pg 459.
} 
deduce como consecuencia irrefutable, que, no obstante el litisconsorcio material, el interviniente no puede realizar aquellos actos procesales que emanan exclusivamente de la posición de parte, tales como la reconvención, la ampliación de demanda, su modificación, etc ${ }^{\text {,75. }}$.

Después, el autor se refiere a la denuncia del litigio (litis denunciatio que contempla el pgfo 69 de la ZPO -en la versión que seguimos es el número 72- a la que considera que contiene un acto extrajudicial que realiza la parte y no el tribunal que consiste en una declaración de voluntad dirigida al tercero en el sentido de estar esperando que acceda al juicio. Tal declaración tiene por finalidad tutelar el interés del citante y no el del receptor: "Es un acto específicamente egoísta aunque sea de utilidad para el tercero", que puede tener diversos objetivos tales como crearse una situación jurídica favorable con respecto al receptor asegurarse el regreso contra él, o asegurarse contra su ataque; o deshacerse del proceso con respecto al adversario o evitar el peligro de un doble proceso o una doble condena" ${ }^{, 76}$.Expresa el autor que esas tres finalidad tienen expresión en los pgfos 69,72 y 73, (pgfos 72,75 y 76 respectivamente en la versión a la que recurrimos) pero mientras que en el tercero no se trata sino de una asunción del litigio y en el segundo de una intervención principal; en el primero, la litisdenunciatio propia del derecho común,(denuncia de litis en sentido estricto) "la accesión del receptor es una intervención por adhesión"

\footnotetext{
${ }^{75}$ Wach Adolf.Obra y tomo citados,pg 460.

${ }^{76}$ Wach Adolf.Obra y tomo citados,pg 460

${ }^{77}$ Wach Adolf.Obra y tomo citados,pg 460
} 
Tratando específicamente la hipótesis del pgfo 69( pgfo 72) Wach sostiene que la denuncia tiene por objetivo salvaguardar la acción de regreso contra el tercero o protegerse de su ataque, todo en vista de un posible resultado desfavorable del pleito; agrega que la sentencia en sí no hace cosa juzgada contra el tercero porque si lo hiciere con todos sus efectos, desaparecería la razón que justifica la citación y que la finalidad de la litisdenuntiatio es darle al fallo un efecto que en sí misma no tiene, como es el de otorgarle eficacia también contra el tercero ${ }^{78}$. Analizando la esencia de la litis denuntiatio, dice que no es un acto de persecución jurídica, pues "su finalidad es tutelar el interés del receptor en un proceso futuro, no en el actual; no tiene por finalidad realizar un derecho material o procesal de representación o asistencia en el proceso, o, en su caso, un deber del receptor de acceder; no es ni una demanda de intervención ni un acto coactivo a tal efecto. Puede comparársela a una protesta o admonición jurídicamente relevante, porque es una puesta en conocimiento del pleito, motivada internamente por la relación jurídica material entre el denunciante y el receptor y relevante para expresar al mismo tiempo, en forma legal, la voluntad de aceptar al receptor como interviniente adherente. Por eso, no contiene ningún elemento de coacción personal, ni una citación, ni ningún otro pedimento procesal o material; por eso no hay procedimiento ni resolución basados en esa denuncia; en ella no se expresa siquiera el deseo de que el tercero acceda" ${ }^{\text {, }}$.

Goldschmidt, luego de ocuparse de la intervención principal o excluyente, pasa a considerar la intervención adhesiva; señala que se produce cuando un tercero con interés jurídico en la victoria de una de las

\footnotetext{
${ }^{78}$ Wach Adolf.Obra citada, V.II,pg 463.

${ }^{79}$ Wach Adolf.Obra citada. V.II,pg 464
} 
partes, ingresa para ayudarle en calidad de interviniente adhesivo. La intervención en esas condiciones crea el derecho de intervenir cuando la fuerza de la cosa juzgada de la sentencia haya de extender sus efectos en pro o en contra del tercero; o si la sentencia que recaiga puede ejecutarse contra el tercero -ejemplo sentencia contra el propietario inscripto en registro que pueda ejecutarse contra el "verus dominus"; o si la sentencia ha de producir efectos accesorios contra el tercero; o si ha de producir efectos probatorios, sea en la relación entre el tercero y la contraparte (por ejemplo, la sentencia contra el deudor para los fiadores, o los propietarios de una cosa pignorada); o si puede tener efectos probatorios en la relación citante-tercero, para futuros procesos de regresión ${ }^{\mathbf{8 0}}$.

Sigue señalando que el interviniente adhesivo "no se hace parte. No puede por tanto, pedir nada para sí, ni se puede pedir nada de él, a excepción de lo que atañe a las costas por su intervención. Tampoco puede -sin perjuicio del Pgfo 62 aplicable por analogía- modificar su demanda o desistir de ella, renunciar a la pretensión de la misma, allanarse o transigir, renunciar al recurso o desistir del mismo, ni renunciar al derecho de excepcionar faltas, ni expresar su conformidad para que decida el magistrado delegado del Tribunal en vez de éste. Por lo demás puede ejecutar todos los actos procesales que la parte a quien ayuda hubiera podido realizar, si la misma no se opone. Está facultado, por tanto, particularmente para hacer valer medios de ataque y de defensa, proponer pruebas, interponer recursos (también -aunque esto es dudoso después de lo que dice el pgfo 66, II- pedir la revisión del procedimiento) e impulsar la notificación de las sentencias favorables para su parte. La admisión de hechos y el juramento que haga el interviniente obligan a aquélla -en el

\footnotetext{
${ }^{80}$ Goldschmidt James. Obra citada en nota 64pg.447).
} 
caso de que esté presente- si no se opone en el acto (por analogía en los 85 ap. 2 y 90 II)" 81.

Señala que la sentencia hace cosa juzgada para el interviniente adhesivo y el coadyuvado en cualquier proceso de regresión entre ambos, pero debe "distinguirse cuidadosamente del que atañe a la relación en que han de estar el interviniente adhesivo y el adversario de la parte a quien ayuda" y "lo fundamentos de hecho y de derecho de la sentencia anterior se hacen incontrovertibles, y así queda firme la existencia de vicios en la cosa vendida si la sentencia decreta el saneamiento; y es indiscutible la mala acomodación de las mercancías al ser cargadas si declara la obligación de resarcimiento de daños al expedidor, la culpa principal, si establece la responsabilidad de los fiadores, la responsabilidad del deudor, etc. ${ }^{, 82}$.

Continúa diciendo que el interviniente adhesivo está en una situación más independiente si la gestión procesal de su parte puede producir efectos contra él en relación con el adversario de la parte a quien coadyuva. En ese caso, y de acuerdo al pgfo 69 el interviniente es considerado litisconsorte de su parte, cosa que quiere decir que puede efectuar actos procesales aun en oposición de su litisconsorte.

Pasa luego a la litis denuntiatio, a la que define como el aviso dado por una parte al tercero de la pendencia de un proceso, dejando al arbitrio del mismo el acudir en auxilio del denunciante en calidad de 1)interviniente adhesivo (pgfos 72-74) que comprende a la que tiene sentido estricto que se da cuando la parte citante entiende que en caso de derrota, tiene derecho

\footnotetext{
${ }^{81}$ Goldschmidt James.Obra citada,pg.448

${ }^{82}$ Goldschmidt James.Obra y tomo citado,pg.449)
} 
a ejercitar una acción de garantía contra el citado o la citación al litisconsorte propio pero no a su adversario, con posibilidad de que el citado produzca nuevas citaciones. De esa manera, "la parte se asegura de que, en relación con el tercero, la sentencia produce el mismo efecto que si éste hubiese participado en la causa como interviniente adhesivo “ $\mathbf{8 3}$. Queda al arbitrio del tercero intervenir o no pero si lo hace toma la posición de un interviniente adhesivo.

2) la que genera posibilidad de una intervención principal-litigio entre pretendientes de un derecho- $\mathrm{y}$

3) la que abre la posibilidad de seguir el proceso como demandado (nominatio o laudatio auctoris) $^{\mathbf{8 4}}$.

W.Kisch explica que la intervención adhesiva (voluntaria) tiene por finalidad coadyuvar con alguna de las partes originarias; se divide en adhesiva simple y adhesiva especial (calificada o litisconsorcial); en la primera, el interviniente está en relación de dependencia con el coadyuvado-ver en el punto 9 su acercamiento a la teoría de la representación-en atención al interés propio que tiene en el resultado del proceso, como un coadyuvante (Gehilfe) especial de la parte principal, que actúa a nombre propio $^{85}$.

No ocurre lo mismo en la segunda en la que el tercero se enfrenta a la circunstancia de que la sentencia que recaiga extienda sobre su persona su fuerza de cosa juzgada o constitutiva. Expresa entonces que "Aquí éste

\footnotetext{
${ }^{83}$ Goldschmidt James.Obra y tomo citados,pg.451

${ }^{84}$ Goldschmidt James.Obra y tomo citado, pgs.450 a 451).

${ }^{85}$ Kisch W. Obra citada,pgs 322 y 323.
} 
no deja de ser un interviniente adhesivo que conduce un proceso ajeno, no propio; pero está tan interesado en su resultado como la parte principal. Por eso no está en el mismo estado de dependencia, que antes hemos visto con respecto la conducta de ésta; y así puede ejecutar válidamente todos aquellos actos que puedan redundar en beneficio de la parte principal, sin tener en cuenta si están o no en oposición con los de ella :p. e., discutir las afirmaciones de la parte contraria admitidas por la principal, emplear los medios de prueba de que ésta no se ha servido o interponer los recursos que no ha aprovechado, etc. Los actos que realice obran sobre el proceso ajeno como los ejecutados por un litisconsorte" ${ }^{\$ 86}$. Pasa luego a referir el instituto de la litisdenunciación que se da si la intervención es provocada por una de las partes cuando en caso de ser vencida tenga un derecho de regresión contra el tercero, o, al contrario, que el tercero pueda tener acción regresiva contra ella. Pone entonces en conocimiento del tercero, la existencia del pleito, su estado y la causa de su denuncia ofreciéndole ocasión para que se incorpore al mismo. Si lo aprovecha participando, pasa a ser considerado un interviniente adhesivo. Si no actúa o se niega expresamente a hacerlo igualmente habrá de admitir como válida la sentencia que se dicte tal como si también lo fuera ${ }^{87}$. Considera luego que la litisdenuntiatio lleva en dos casos a la intervención adhesiva: se trataría del llamado al tercero pretendiente en el que el tercero consigna la obligación que se le reclamara (en una posición procesal que el autor considera sui géneris pero analógicamente cercana a la intervención principal) y la llamada al

\footnotetext{
${ }^{86}$ Kisch W. Obra citada,pg.324.

${ }^{87}$ Kisch W. Obra citada, pgs 325 y 327
} 
poseedor mediato (nominatio auctoris) en donde hasta se puede producir una sucesión procesal ${ }^{\mathbf{8 8}}$.

Rosemberg refiere a la "denuncia del litigio" o "litis denuntiatio", definiéndola como "la comunicación formal a un tercero de una controversia pendiente por una de las partes", dándole así la oportunidad de intervenir como adherente o en los casos de los pgfos 75 a 77 . El objetivo de la denuncia es producir la intervención y con ello "evitar distintos juicios sobre el mismo hecho permitiendo que operen sobre el tercero las mismas consecuencias que se dan con respecto al adherente". No significa que se haga valer la pretensión que se discute en contra del tercero, "sino que anuncia a lo sumo que se la hará valer en el futuro". Se conforma como un derecho del denunciante pero no como un deber (hace excepción en el caso del convenio internacional sobre transporte en ferrocarril que menciona). Señala también que la denuncia puede hacerse en todo momento del proceso anterior a que se haya producido la cosa juzgada. Es factible dirigirla contra quien no sea parte, incluso al propio litisconsorte pero no contra el adversario. Expresa el autor que "La denuncia de la controversia debe tener una causa, es decir el denunciante del litigio debe afirmar un hecho, en el cual si existe, para el caso de su derrota en el proceso pendiente (no de su victoria"...aunque también hay una en necesidad para ello) pueda fundar una pretensión por garantía o indemnización o debe esperar una pretensión de esta especie del receptor de la denuncia". "El denunciante del litigio debe esperar una acción de garantía o de indemnización, si es responsable ante el receptor de la denuncia del éxito de la controversia". Señala que el receptor de la denuncia puede también adherirse al adversario sin que por ello cambien

${ }^{88}$ Kisch W. Obra citada, pgs 326 y 327 
los efectos de la citación, haciéndolo como interviniente adherente con los efectos de la adhesión común pero, si se diera el supuesto del pgfo 69 se producirán también los litisconsorciales según el pgfo 74.I). Tanto si adhiere o si no concurre será alcanzado por los efectos de la sentencia ${ }^{\mathbf{8 9}}$.

Schönke por su parte, recuerda que como lo estableció la jurisprudencia del Tribunal Supremo alemán, la litisdenunciación, como mera comunicación formal de la pendencia de una causa dirigida por una de las parte a un tercero, no significa el ejercicio de una verdadera acción procesal.

Tiene como objetivo dar ocasión al tercero para que ingrese como interviniente adhesivo, o como principal o para asumir la causa como demandado. En el primer caso "Es admisible ...cuando una parte para el caso de serle desfavorable el resultado del litigio, crea poder ejercitar contra un tercero una acción de garantía o indemnidad, o cuide los derechos de un tercero (pgfo 72 I). Da como ejemplo del primer sentido, el del comprador demandado por defectos de la cosa que llama a quien se la vendió o el del fiador que busca repetir del deudor principal; con el segundo sentido pone el caso de quien lleve un juicio por cuenta de bienes de tercero, como los comisionistas o depositarios.

Los efectos del llamado consisten en crear todas las consecuencias de una intervención adhesiva independientemente de que el tercero ingrese o no en el juicio cosa que no le es obligatoria; pero la posibilidad de alegación por parte del citado de una mala defensa, solamente será posible

\footnotetext{
${ }^{89}$ Rosemberg Leo. Tratado de Derecho Procesal Civil. Tomo I, pgs 278 a 283.EJEA. BuenosAires. 1955. Traducción de Angela Romera Vera de la Quinta edición alemana de la obra "Llehrbuch des deutschen Zivilprozessrechts". C.H.Beck'sche Verlasbuchhandlung. München und Berlin.1951
} 
por los momentos anteriores a la citación y no con respecto a su ingreso efectivo.

Analiza luego la litisdenunciación que tiene por objeto una intervención principal o litigio entre pretendientes, para lo que se requiere que un tercero pretenda para sí el crédito reclamado en el litigio, motivo por el cual el deudor demandado puede denunciar el litigio a ese tercero; señala entonces que el llamado solamente tiene efectos especiales si el citado interviene en el pleito y que no se aplican los principios de la intervención adhesiva, pues la actividad del tercero más se asemeja a la de una intervención principal. Si la demandada deposita el importe requerido renunciando a su devolución, se le debe desligar del juicio.

Por último y en el supuesto de la citación para promover la intervención como parte señala que sus efectos son: a) permitir al demandado pedir la suspensión del juicio hasta que no se practique la citación al tercero. b) si el tercero no formula declaración alguna el demandado queda facultado para satisfacer al actor sin que el llamado pueda imputarle responsabilidad alguna c) si el citado reconoce ser cierta la afirmación del demandado este es liberado del juicio, siempre que asuma el proceso que de lo contrario sigue contra aquél.

En la doctrina actual Leible distingue entre la intervención adhesiva prevista en el pgfo 67 - en la que el interviniente puede presentar, actuando a nombre propio, hechos, promover pruebas, cuestionar, admitir, interponer recursos e impugnaciones siempre que no se ponga en oposición con la parte a la que adhirió- y la intervención adhesiva contenciosa, del pgfo 69, que equipara el interviniente a un litisconsorte de los considerados por pgfo 61 pero que en realidad no lo es y no tiene condición de parte, si bien se le reconocen facultades más amplias que las del interviniste adhesivo. Así, 
puede oponerse a la contraparte, sin consideración a la conducta de la parte principal, presentar medios de ataque y defensa, revocar una confesión de la principal o contradecir sus reconocimientos o desistimientos, interponer recursos, pero no puede reconvenir ni plantear defensas propias ${ }^{\mathbf{9 0}}$. La temática referente a la intervención obligada se encuentra regulada en los parágrafos 72 a 73 ZPO y se produce a petición de parte por litis denuntiatio que significa "poner en conocimiento de la litis a un extraño al proceso, exhortándolo a participar en "apoyo de la parte notificante". ${ }^{11}$ como interviniente adhesivo. El citado tiene la libertad de comparecer o no y si lo hace, su actuación se rige por los principios de la intervención adhesiva y en su caso por los de la de la intervención adhesiva contenciosa. Concurra o no caerá bajo los efectos de la cosa juzgada ${ }^{92}$.

\section{Italia}

a) La codificación anterior. El CPC de 1865, refería en su art.201 la intervención voluntaria de terceros, en tanto el art.203 hacia lo propio con la convocatoria al tercero por iniciativa de las partes ${ }^{93}$ norma que se

\footnotetext{
${ }^{90}$ Leible Stefan. Proceso Civil Alemán, pgs 450 y 453. Biblioteca Jurídica Dike. Konrad Adenauer. Stiftung .Medellín. Colombia. 1999

${ }^{91}$ Leible Stefan, Obra citada, pg.454

${ }^{92}$ Leible Stefan, Obra citada, pgs 453 a 456

${ }^{93}$ Art.203 ."Cada una de las partes puede llamar en causa a un tercero a quien crea común la controversia"
} 
considera comprendía también el caso del litisconsorcio necesario. ${ }^{94}$. El código regulaba la acción de garantía en sus arts.193 y ss. ${ }^{95}$.

Con relación al primero de esos dispositivos, Mattirolo dice que cada una de las partes puede citar a un tercero a quien crea que se extiende la cuestion.'La controverasia puede ser común ó ex re petita ó ex causa petendi, y por tanto consistir en la identidad de la cosa debida por una de las partes y por el tercero ó en la identidad del título, ó sea del derecho que se hace valer en juicio, y que corresponde, igualmente á una de las partes y al tercero cuya intervención se pide" ${ }^{\text {96. }}$.

Señala el autor que la intervención puede ser pedida en el término establecido para posibilitar la intervención voluntaria, pero para efectivizarla, se hace necesaria la convocatoria formal por la parte que pide el llamamiento. El llamamiento puede generar oposición tanto de la contraria como la del tercero a cuyo efecto se formara una vía incidental. El tercero, obligado a intervenir " $\mathrm{y}$, por tanto a sufrir consecuencias gravísimas, tiene y debe tener plena y absoluta libertad de defensa; por lo que, a diferencia del que interviene espontáneamente, no estará obligado a respetar el estado de la causa, sino que podrá impugnar por defecto de fondo o forma cada uno de los actos anteriores del procedimiento, así como deducir todas aquellas pruebas que estime necesarias en sostenimiento de su derecho., ${ }^{, 97}$.

\footnotetext{
${ }^{94}$ Calamandrei Piero. Instituciones ... V.II,pg. 339

${ }^{95}$ Chiovenda Giussepe, Obra citada.T.II,V.II.,pgs 642 a 656.

${ }^{96}$ Mattirolo Luis, Instituciones de Derecho Procesal Civil, Traducción de Eduardo Ovejero. Tomo II,pgs 359 .Ed.La España Moderna. Madrid

${ }^{97}$ Mattirolo Luis, obra citda, pg.360
} 
Chiovenda señala que el Código de 1865 reduce a una sola disposición (art.201) el tratamiento de la intervención adhesiva como institución opuesta a la intervención principal; con respecto al primer instituto señala que el interviniente adhesivo se allega al pleito para ayuda de una parte, de manera que todo lo que puede hacer es por un derecho ajeno. Recuerda sin embargo que en la legislación alemana se distinguían dos formas de adhesión, la litisconsorcial y la simple ${ }^{\mathbf{9 8}}$.

Ya en el tema de la intervención coactiva, (art.203) analiza la que llama "intervención forzosa", asignando a cada una de la partes la facultad de llamar al pleito "a quien crea que es común la contienda", posibilidad que históricamente vincula con la adcitatio. En trance de conceptualizar a la "controversia común", dice con respecto a dicha facultad, que su ejercicio tiene por base la existencia de un interés específico derivado de una situación de contienda común con el tercero "lo cual presupone que el actor o del demandado se encuentran en el pleito por una relación jurídica común con el tercero o conexa con una relación en que el tercero se encuentre con ellos, de manera que esté en cuestión el mismo objeto y la misma causa petendi (o uno u otro de los dos elementos) que podrían ser materia de litigio frente al tercero, o de parte del tercero y que habrían podido dar al tercero la posición de litisconsorte con el actor o con el demandado"99. Explica que el llamamiento en la intervención forzosa es sustancialmente muy distinto del llamamiento al pleito del demandado por parte del actor, puesto que no implica per se la proposición de una demanda contra el tercero, o por parte suya; no es sino el llamamiento de quien había podido ser, pero no quiere ni puede ser obligado a ser

\footnotetext{
${ }^{98}$ Chiovenda Giussepe, Obra citada, T.II,V.I.,pg.33

${ }^{99}$ Chiovenda Giuseppe, Obra citada T.II,V.II.,pg.643
} 
litisconsorte del actor, o de quien habría podido ser litisconsorte del demandado, pero no lo es, porque el actor no quiere ni puede ser obligado a llamar; y ante todo, tiene el doble efecto, de extender, en todo caso, al tercero llamado, la autoridad de la futura cosa juzgada"100. Sin embargo sostiene que en tanto el llamado no plantee una demanda o las partes no la instauren contra él, no será parte sino "tercero sujeto a la decisión con todos los derechos inherentes a tal cualidad"101. Con relación a la parte convocante expresa que siendo el actor, podrá citar tanto a sus litisconsortes como a los de la parte demandada, pero que solamente en el primer caso estará operando una intervención forzosa verdadera y propia, mientras que en el segundo formulará "una verdadera extensión de la demanda". En cuanto a los llamamientos del demandado, éste podrá hacerlo -generando una intervención forzosa propia- tanto con los litisconsortes propios como con los del actor ${ }^{102}$. Sin embargo, "La parte interesada sólo tiene facultad de llamar al tercero ella misma directamente y no puede pretender que a ello provea la otra parte. En particular, el demandado no puede pretender que el actor llame al pleito a los litisconsortes, lo cual se resolvería en una exceptio pluirium litissortium, que nuestra ley sólo admite en casos aislados" ${ }^{103}$.

Señala el insigne procesalista que externamente el llamamiento del tercero se acerca al del demandado pues ambos tienen en común el elemento coactivo y que por eso, a diferencia de la intervención voluntaria

\footnotetext{
${ }^{100}$ Chiovenda Giuseppe, Obra citada T.II,V.II.,pg. 643.

${ }^{101}$ Chiovenda Giuseppe, Obra citada T.II,V.II.,pg.643 .

${ }^{102}$ Chiovenda Giuseppe, Obra citada T.II,V.II.,pg. 644.

${ }^{103}$ Chiovenda Giuseppe, Obra citada T.II,V.II.,pg 644.
} 
que se produce mediante escrito, aquél se propone como citación, pero comunicado por escrito a la audiencia o notificado ${ }^{\mathbf{1 0 4}}$.

Por fin, explicita las facultades el tercero que, "a semejanza del demandado, debe tener plena libertad de defensa como si el pleito comenzare en cuanto a él, sin recibir perjuicio por preclusiones anteriores" 105 de ahí que pueda oponerse a la convocatoria y quedar libre de la sentencia. Además "Una vez entrado en el pleito, el llamado, si no puede o no quiere quedar como espectador pasivo (causae adesse), puede sumir, según los casos, las más variadas posiciones: puede hacerse actor litisconsorte del actor originario; encontrándose en la condición de litisconsorte del demandado originario, adherirse a la defensa de las dos partes; proponer demandas como interviniente principal; reconvenir. y también apelar." 106. A su vez, las partes pueden proponer contra el intervenido según los casos, demandas, excepciones, reconvenciones ${ }^{\mathbf{1 0 7}}$. El autor señala que dentro de la figura general que queda reseñada, deben mencionarse como casos especiales, la litisdenuntiatio o denuncia del pleito; la indicación del poseedor mediato (laudatio o nominatio auctoris), el llamamiento del tercero pretendiente $y$ el llamamiento en garantía. La denuncia del pleito, se da para preservar una acción de regreso, posibilitando con ella la actividad coadyuvante del citado, con la consiguiente imposibilidad de que pueda alegar en el juicio futuro la excepción de negligente defensa .Da como ejemplos, el llamamiento del comprador al vendedor en caso de evicción, la del arrendatario al

\footnotetext{
${ }^{104}$ Chiovenda Giuseppe, Obra citada, T. II. V. II. pg 644.

${ }^{105}$ Chiovenda Giuseppe, Obra citada, T. II, V. II ,pg 645

${ }^{106}$ Chiovenda Giuseppe, Obra citada T. II, V. II,pg 646.

${ }^{107}$ Chiovenda Giuseppe, Obra citada T. II, V. II,pg 646
} 
arrendadores en casos de molestias por cuestiones de propiedad o servidumbre. La indicación del poseedor mediato para librarse del pleito indicando a nombre de quien posee. (En cuanto a la acción de garantía ver en el punto 2 el tratamiento que le da Chiovenda).

El llamamiento al tercero pretendiente, se da en los supuestos en que un sujeto se vea ante diversas pretensiones que le reclaman el cumplimiento de la misma obligación o la restitución de la misma cosa. Señala Chiovenda que la ley italiana, a diferencia de la alemana, no menciona el caso pero que puede asimilarse prácticamente a los demás supuestos de llamamiento en causa, esta vez protagonizado por el demandado en tanto que el actor "conserva su carácter y condición originarios. El llamado al pleito que descuida hacer valer y defender su pretensión, encuéntrase respecto del actor originario, en la condición de demandado en acción de declaración"108.

Carnelutti basándose en su concepción del proceso acumulativo, enseña que ello importa introducir en el proceso pendiente otro litigio conexo, objetivo que puede lograrse mediante una demanda y su reunión posterior con el proceso referido. Especifica que, sin embargo, la ley admite que un proceso se extienda directamente sin necesidad de recurrir a aquel mecanismo. Ello pasa con la reconvención y con el acertamiento incidental especie de prejudicialidad destinada a servir al litigio y eventualmente a las diversas consecuencias que puede acarrear. Tales figuras juegan en torno de un litigio en el que no participan sino los sujetos originarios (actor y demandado). Puede ocurrir sin embargo, que la acumulación de litis signifique la incorporación de otros sujetos, cosa que pasa en la

\footnotetext{
${ }^{108}$ Chiovenda Giussepe, obra, tomo y volúmen mencionados, pg. 648).
} 
intervención principal de terceros, la acción de garantía y el llamamiento al tercero pretendiente ${ }^{109}$.

El tratamiento de la intervención principal lleva al maestro a referirse a los arts 201 y 203 CPC Italia y a expresar que la diferenciación entre intervención voluntaria y coactiva aporta más confusión que claridad en el tema de la intervención de terceros. Lo relevante verdaderamente está en la distinción entre intervención por adhesión e intervención principal sin que pueda existir alguna categoría intermedia ${ }^{110}$. La intervención por adhesión no incorpora ningún litigio propio sino un nuevo sujeto de la acción; toda intervención que opere de esa forma no es sino adhesiva; por el contrario, la principal importa que el tercero voluntariamente incorpora un litigio propio (ad infringendumiura utriusque competitoris), pero conexo con el existente para ser resuelto en el mismo proceso, constituyéndose así en parte en sentido sustancial; o bien la incorporación del nuevo litigio se hace por iniciativa de alguna de las partes actuantes y es entonces coactiva. “Entre la intervención principal voluntaria y la intervención coactiva hay exactamente la misma diferencia que se encuentra entre la posición del actor y la del demandado; si el tercero interviene voluntariamente, asume la primera; si es llamado a intervenir asume la segunda posición. La única particularidad es que en lugar de ser actor o demandado en un proceso autónomo, es actor o demandado en un proceso ya pendiente por un litigio conexo con el suyo. El interventor por adhesión no puede ser llamado porque no podría ser demandado en un procesos autónomo; en cuanto al interventor principal, es aplicable la razón inversa". Significativamente, Carnelutti vincula el art.203 con el art.36 CPC Italia pues al posibilitar que

\footnotetext{
${ }^{109}$ Carnelutti Francesco. Sistema ..citado.T.II,pg.683.

${ }^{110}$ Carnelutti Francisco.Sistema...citado,T.II,pg.690.
} 
cada parte pueda llamar al proceso, está reconociendo la existencia del derecho a proponer demanda judicial, pues "para que una parte pueda provocar la intervención del tercero (llamar al pleito al tercero), conviene que esté (o pueda estar) en litigio con él, como para que el tercero pueda llevar a cabo la intervención principal, conviene que esté ( pueda estar) en litigio con una de las partes ${ }^{111}$.

b) El Código vigente. El Título IV del Capítulo IV de su Libro I del actual CPC de Italia, se denomina "Ejercicio de la acción". En el mismo, entre otros decisivos temas, la ley refiere al litisconsorcio necesario (art. 102) ,al facultativo (art. 103), la intervención voluntaria (art. 105), a la que se produce a instancia de parte (art. 106) o por decisión judicial (art. 107) y a la extromisión del garantizado (art. 108). ${ }^{112}$

${ }^{111}$ Carnelutti Francesco. Sistema... citado T.II,, pg 693.

${ }^{112}$ Art.102. Litisconsorcio necesario. Si la decisión no pudiese ser tomada sino con la presencia de varias partes, estas deben concurrir o ser citadas en el mismo proceso.

Cuando este se promueva por algunas o contra alguna de ellas tan sólo, el juzgado ordenará la integración del contradictorio dentro de un término perentorio por él establecido.

“Art. 106: "Cada una de las partes puede llamar al proceso a un tercero respecto del cual considere común la causa o por el cual pretenda estar garantizada”

“Art. 107. Intervención por orden del juez. El juez cuando considerare oportuno que el proceso se sustancie con un tercero con el cual se considere que la causa es común, ordenará su intervención."

“Art. 108. Extromisión del garantido. Si el garante comparece y acepta asumir la causa en lugar del garantido, este puede obtener su extromisión. Esta es dispuesta por el juez 
Ciñéndonos al objeto de nuestro estudio vemos que el art.106 CPC regula dos supuestos que específicamente se mencionan: a) comunidad de causa b) llamada en garantía. En cuanto al primero haremos reseña de diversas opiniones doctrinarias sin dejar de señalar que también son aceptables para el tema, las que antes consignamos (Mattirolo y Chiovenda y Carnelutti) referidas a la ley procesal de 1865 antecedente directo del ordenamiento vigente. En lo vinculado con el segundo (acción de garantía), nos remitimos al punto 2 .

Tratando de hacer un esquemático relato de los aspectos procedimentales del CPC italiano vinculados con la intervención de terceros por iniciativa de parte, puede verse que el art. 163 establece que la demanda (con todos los requisitos que fija dicho dispositivo) debe ser propuesta mediante citación oficial al demandado invitándolo a comparecer a una audiencia señalada en día preciso, elegido por la actora de entre los predeterminados judicialmente para la comparecencia de las partes ante el juez instructor(udienza di comparizione). Igualmente, el demandante deberá promover la convocatoria al tercero que creyese conveniente y generar la correspondiente citación (art. 269 primera parte) ${ }^{\mathbf{1 1 3}}$; una vez. producido dicho acto y antes de dicha fecha -en los plazos fijados por el

por ordenanza pero la sentencia de mérito pronunciada en el juicio, despliega sus efectos también contra el extromitido"

"Art.109: Extromisión del obligado. Si se discute a cuál de las partes corresponde una prestación y el obligado se declara pronto a cumplirla a favor del que tenga derecho a ella, el juez puede ordenar el depósito de la cosa o de la suma debida y, después extromitir del proceso al obligado.

${ }^{113}$ Recordamos que en el sistema italiano, la citación al tercero por parte del actor no significa sino demandarlo. Ver al respecto la opinión de Chiovenda que transcribiéramos; igualmente señala que esa es la interpretación que se da normalmente, ( Satta Salvatore. Obra citada, V.I, pg. 156) 
art.163 bis-la demandante -y el tercero en su caso- deben constituirse en la secretaría del órgano jurisdiccional competente para producir la citación, a los fines de la formación y entrega del "fascículo", legajo en el que se incorpora la documentación y elementos probatorios transportables que fueron declarados en la demanda, las actuaciones correspondiente a la citación y el pedido de inscripción de la causa en el registro la secretaría. Simétrica actividad corresponde al demandado en cuanto debe constituirse en la secretaría antes de la audiencia y formalizar su fascículo con la contestación de la demanda, excepciones, pruebas y contrademanda si es que la propusiere (arts.166 y 167). Este último artículo indica también que el demandado, en su misma "comparsa di risposta" pedirá la citación del tercero, si así lo desea, pero el art.269 segunda parte, indica que aquella oportunidad se brinda bajo pena de decaimiento del derecho de citación. Luego de ello, se procederá a la designación del juez instructor que se hará cargo del pleito (art.168 bis). De la contestación del demandado puede resultar que el actor también quiera citar a un tercero cosa que deberá hacer a más tardar dentro de la audiencia de comparecencia bajo pena de decadencia del derecho ${ }^{114}$. Se procederá entonces a fijar nueva audiencia y a practicar las citaciones correspondientes (art.269, tercera, cuarta y quinta parte parte): el art.271 impone al tercero la realización de la misma actividad que disponen los arts.166 y 167 si requiriese a su vez el llamamiento de otro tercero.

Según las previsiones del CPC de Italia, art.107, el juez, advertido que en el proceso se discute una cuestión que es común a un tercero

\footnotetext{
${ }^{114}$ Ugo Rocco, extiende esa posibilidad a la parte demandada "por cuanto la necesidad de la intervención del tercero podría surgir después de la citación o después del escrito de comparecencia de respuesta".( Rocco Ugo.Obra citada, T. III. pg 859)
} 
dispone su citación oficiosa. Es la citación identificada como iusso giudice Se complementa de ese modo y con otra modalidad de intervención coactiva, el sistema encabezado por el art.106 que prevé la convocatoria del tercero a pedido de parte. Precisamente Calamandrei recuerda al efecto la opinión de Chiovenda para quien la intervención por orden del juez que contiene el art.205 CPC Italia de 1865 tiene una finalidad instructoria, como lo es servir de fuente de conocimiento del magistrado, opinión que según el maestro de Florencia perdió actualidad desde que el art.107 del nuevo CPC, otorga a la citación oficiosa la misma naturaleza y finalidades que la del art.106 ${ }^{115}$.

Allorio recuerda la teoría de Nencioni según la cual en la intervención voluntaria, entre la intervención adherente y la principal se da un tertium genus constituido por la intervención litisconsorcial que define como la de los legitimados a accionar, o, en otras palabras, a introducir una litis propia en el proceso. Se muestra contrario a tal criterio, invocando el derecho germano para sostener que la litisconsorcial no escapa a la adhesión y deja pendiente el tema de precisar qué sujetos entran en esa categoría que merece no estar colocada en una estricta subordinación a la parte coadyuvada : "pero entre los terceros que pueden hacer intervención por adhesión ,hay toda una categoría de ellos, que se siente ser digna de una mayor protección, que se actúa concediéndose a esos terceros una mayor independencia de iniciativa, frente a la parte principal, como si fuesen litisconsorte de él" ${ }^{\text {"16 }}$. El tema aparece retomado por Satta, como luego se verá, pero ya referido concretamente a la intervención obligada.

\footnotetext{
${ }^{115}$ Calamandrei Piero.Instituciones... citada,V.II,pg.350

${ }^{116}$ Allorio Enrico. Problemas de Derecho Procesal.T.II,pgs 579 a 584.EJEA. Buenos Aires.1964
} 
Carnelutti parte de su idea del conflicto y de la litis. Los elementos de la litis son sujetos, objetos y pretensión. Distintas litis son conexas cuando en ellas, uno de sus elementos es igual por más que sean desiguales los demás. Si existe la conexión es posible y hasta oportuno que se compongan mediante el mismo proceso y el mismo juez, pero para que ello ocurra deberá darse la conexidad propia que se configura si entre las litis se dan vínculos de conexión subjetiva y objetiva o causal, así como instrumental, mostrando con ello el fenómeno de la interdependencia entre las litis. La conexidad instrumental está constituida por la presencia de las mismas razones $\mathrm{y} / \mathrm{o}$ bienes que permitan ser aplicados a todas las litis. La conexidad impropia se dará si las litis no son conexas por identidad de alguno de sus elementos pero alguno de ellos son similares por plantearse en cada uno de ellos la misma cuestión ${ }^{117}$.

A partir de esa idea, pasa a trabajar el concepto de proceso acumulativo que no es sino el que permite reunir varias litis para su solución conjunta y que puede ser necesario o facultativo, capaces ambos de generar -aunque no siempre- estructuras subjetivas litsconsorciales ${ }^{118}$. Ya en el campo de lo facultativo, el litisconsorcio puede ser inicial o sucesivo y este último puede ser por intervención principal o por reunión de procesos, diversificación de la que tomamos solamente el primer término, que lleva a considerar una manera de ingreso voluntaria (correspondiente al art.105) y otra coactiva (art.106 ). Dice al respecto que "la intervención supone la conexión subjetiva entre la litis ya deducida en el proceso y la litis que se introduce en él; puesto que con el mismo un tercero entra en el proceso (art.106), esto quiere decir que la otra parte (en

\footnotetext{
${ }^{117}$ Carnelutti Francisco. Instituciones ...citada V.I pgs 40 y 41

${ }^{118}$ Carnelutti Francesco. Instituciones...citada,,v.I,pg 387 y 388
} 
la litis en la que el tercero es parte) está ya en el proceso; precisamente quien sea adversario de una persona que ya es parte en un proceso por una litis diversa, puede, si concurren ciertos requisitos, entrar en él, espontáneamente o por fuerza"119. En la voluntaria, Carnelutti plantea la distinción entre intervención principal -adhesiva autónoma (art.105 primera parte) y accesoria (art.105, segunda parte)- , y adhesión o dependiente, que no otorga condición de parte porque el interventor no es sujeto de una litis. La primera, que no se admite en los casos de conexión impropia, significa que el tercero sustenta "una verdadera intervención principal, teniendo de particular que el interventor propone un pretensión paralela a la pretensión de una de las partes en lugar de divergente de las pretensiones de ambas"

Llegando ya al concepto de comunidad de causa del art.106 C. P.C., Carnelutti dice que "No obstante la diversidad de la fórmula (en lo que hay un defecto de factura del código) el requisito de la intervención coactiva es idéntico al de la intervención voluntaria principal" que requiere la existencia de una litis debatiéndose entre partes sea común al tercero por tener el mismo título o el mismo objeto .Considera entonces que se dará así comunidad de litis, "como modo de decir corriente, aunque menos exacto, para denotar la interdependencia"121.

Pone de manifiesto que la hipótesis de llamamiento al tercero pretendiente, no está textualmente prevista pero queda comprendida en la primera parte de la fórmula del art.106. (causa común). Expresa que tal

\footnotetext{
${ }^{119}$ Carnelutti Francesco. Instituciones...citada, v.I, pg 396.

${ }^{120}$ Carnelutti Francesco. Instituciones... citada, v.I,pg 397.

${ }^{121}$ Carnelutti Francesco. Obra citada, V.I, pg. 398.
} 
llamamiento supone la pretensión contrastante de dos o más personas a la misma prestación, de modo que la pretensión de una excluya la de la otra. Dentro de tal figura pueden darse dos situaciones básicas: provocación del demandado para que el tercero intervenga adhiriendo a su postura, ya que tiene interés en el triunfo de la misma para obstar a la victoria del actor; "en caso diverso, el llamamiento sirve para introducir en el proceso, mediante la intervención del tercero, la litis entre éste y el demandado, instrumentalmente conexa por el objeto de la litis ya deducida en el proceso" ${ }^{122}$.

Calamandrei comienza por recordar la básica distinción entre intervención voluntaria y coactiva (llamamiento de un tercero en causa, según la letra del CPC Italia). La primera, es principal, (ad infrigendum o ad excludendum iura utriusque competitoris) o adherente; esta última divisible en simple (ad adiuvandum) o litisconsorcial (adherente autónoma). Por su parte la coactiva puede darse por instancia de parte (art.106 CPC Italia) o por orden del juez (art.107 CPC Italia) ${ }^{\mathbf{1 2 3}} \mathrm{y}$ comprende los casos de comunidad de causa (art.106 CPC italiano), llamamiento en garantía, llamamiento en causa del legitimado para contradecir y similar para el tercero pretendiente.

Ya en el campo de la intervención coactiva, nos impone tener presente la diferencia existente entre litisconsorcio necesario -en el que el juez no puede decidir la causa sino integrándola subjetivamente- y la comunidad de causa, en la que la relación del tercero puede ser decidida

\footnotetext{
${ }^{122}$ Carnelutti Francesco.Instituciones... citada, V.I ,pg. 399

${ }^{123}$ Calamandrei Piero.Instituciones, citada...,V.II,pg.315
} 
separadamente de la relación controvertida entre las partes principales ${ }^{\mathbf{1 2 4}}$. Expresa que el llamamiento sirve para reunir a la causa originaria otra conexa tendida entre una de las partes principales y el tercero, en tanto exista entre ambas comunidad de los dos elementos objetivos: objeto y título, "y no, tanto, uno sólo de ellos, puesto que con la expresión “comunidad de causas" la ley ha querido dar a entender una conexión más completa que la proveniente de comunidad de sólo el objeto o sólo el título" ${ }^{, 125}$.

El maestro parte de sostener que el llamamiento en causa puede ser intentado por ambas partes de modo que cualquiera de ellas puede hacerlo tanto con los propios coobligados como con los de su contrario. Al efecto, toma el ejemplo de las obligaciones solidarias y explica que si el llamado se produce con relación a sujetos de una misma relación jurídica sustancial y lo formula el actor con respecto a un sujeto pasivo todavía no demandado, se estará proponiendo la misma pretensión de condena ya desarrollada contra el sujeto accionado inicialmente. En el mismo supuesto, pero ante el llamado hecho por el actor a un coacreedor, la convocatoria no significaría sino un aviso para que reclame conjuntamente con el citante el cumplimiento de la obligación. A la inversa, si la citación proviniese del demandado y fuese dirigida al coacreedor no demandante, tendría el carácter de una demanda destinada a obtener una declaración negativa de certeza; si ese mismo demandado llamase a un codeudor no puede con ello constreñir al actor a demandarlo, sino que lo hará para proponer una demanda de repetición contra dicho codeudor por lo que tuviera que desembolsar en el juicio si lo perdiese.

\footnotetext{
${ }^{124}$ Calamandrei Piero. Instituciones... citado,V.II, pgs. 337 y 338

${ }^{125}$ Calamandrei Piero. Instituciones... citado V.II, pgs. 340 y 341
} 
Concluye entonces en que "no siempre el llamamiento en causa del art.106 implica la proposición de una demanda contra el tercero que dé lugar a la acumulación (subsiguiente) de una nueva causa conexa con la originaria; a veces el llamamiento en causa tiene solamente la finalidad de informar legalmente a un tercero de la pendencia de una causa (denuncia de litis,litisdenuntiatio: cfr. art. 1485 C.C.),al doble objeto de ponerlo en condiciones de participar en ella como litisconsorte juntamente (y no en contraste) con el llamante, asumiendo frente al adversario la misma posición de actor o demandado que tenga el llamante", aparte de extender sobre él la cosa juzgada que" se forme sobre los elementos comunes de la relación de modo que no pueda desconocer en el futuro los efectos de dicha declaración de certeza" ${ }^{, 126}$.

Con respecto al caso del tercero pretendiente, Calamandrei señala que el art.106 CPC Italia no lo menciona pero que resulta de las previsiones del art.109 CPC Italia. Ellas permiten al demandado obligado introducir con relación al tercero una demanda de mera declaración de certeza que tendrá carácter prejudicial con respecto a la relación actor-demandado y permitirá que el tercero asuma con respecto al primero condición de interviniente principal que excluido el demandado seguirá el juicio con el actor ${ }^{127}$.

\footnotetext{
${ }^{126}$ Calamandrei Piero.Instituciones... citado,V.II, pgs 341 a 343.

${ }^{127}$ Calamandrei Piero. Instituciones... citado,V.II, pgs 341 a 343.
} 
El maestro italiano recuerda que en la doctrina se controvierte si el llamamiento en causa, otorga por sí, calidad de parte al convocado. Razona que "según sabemos, tal cualidad no la adquiere sino quien sea sujeto activo o pasivo de una demanda, la cuestión se resuelve viendo si el llamamiento en causa constituye o no, en relación al llamado, la proposición de una demanda" ${ }^{128}$. En esa tarea recuerda que, tanto el llamamiento proveniente del actor (ejemplo de la citación al coacreedor solidario) que lleva al citado a acompañarlo demandando al primitivo accionado, como el llamamiento por parte del demandado (ejemplo de la citación al codeudor solidario), si a raíz de ello el actor extiende su demanda contra el convocado, otorgarán al tercero, carácter de parte. No siendo así, la llamada "no basta para agregar a la causa principal una nueva causa en la que sea parte el tercero, ya que no contiene en sí mismo la proposición de una demanda ni de él ni contra él” ${ }^{, 129}$. Sin embargo, advierte -y va en ello un aspecto medular de su pensamiento- que "puesto que también en tal caso el llamamiento del tercero sirve, según dijimos, para extender también a él los efectos del fallo que se formará acerca de la causa originaria entre las partes principales(de manera que forme estado también contra él la declaración de certeza de los elementos comunes constitutivos de una prejudicial necesaria también de su derecho), desde ese punto de vista se puede admitir que el llamamiento en causa vale, por lo menos, como proposición de una demanda de mera declaración de certeza dirigida con ese limitado efecto, también contra él :y dentro de tales límites, se lo puede considerar parte"

\footnotetext{
${ }^{128}$ Calamandrei Piero. Instituciones... citado,V.II ,pg 343.

${ }^{129}$ Calamandrei Piero. Instituciones citado...V.II, pg 344.

130 Calamandrei Piero. Instituciones... citado,V.II, pg 344.
} 
En lo referente a la citación del garante, Calamandrei distingue dos posibilidades: la primera es la del simple llamado al sólo efecto de hacerle saber la existencia de la litis (litisdenunciatio). Ante ello, el tercero podrá intervenir-si quiere-ad adiuvandum al citante contra su contrario y hasta asumir la causa en los términos del art.108 CPC en tanto la otra parte no se oponga; la otra actitud será mantenerse en pasividad, pero en ambos casos, si el citante es vencido y dirige su demanda de regreso contra el tercero, éste "no podrá ya someter de nuevo a discusión las razones en virtud de las cuales el garantizado salió vencido" ${ }^{131}$. La segunda posibilidad es llamar al tercero en garantía pero accionando de regreso en su contra y formalizando al respecto, la correspondiente demanda para la hipótesis de una derrota ante la contraparte .Ver al respecto el punto $\mathbf{2}$.

Redenti señala que cualquiera de las parte puede utilizar la adcitatio para extender la in ius vocatio al tercero del que piensa tenga algún interés dependiente o reflejo protegido, utilizando al respecto el art.106 del CPC italiano: "No se excluye tampoco que alguna de las mismas partes principales, creyendo que hay un tercero cuyo interés dependiente o reflejo esté protegido por la ley, lo llame ad adiuvando sin esperar a que intervenga él personalmente, y esto, o bien extendiendo a él desde el comienzo la in ius vocatio, o también mediante una citación posterior a que intervenga (adcitatio) valiéndose al efecto del artículo 106"132. "Esta disposición, empírica y elástica aunque a menudo sirva para determinar una inserción- reunión de varias causas, puede también extenderse al caso aquí considerado. La parte principal puede tener un interés de hecho en el llamamiento, ya sea para dividir con él eventualmente la carga de las

\footnotetext{
131 Calamandrei Piero. Instituciones... citado,V.II, pg 346,).

${ }^{132}$ Redenti Enrico.Obra citada T.I,pg.242.
} 
costas, ya para prevenir la posibilidad de posteriores oposiciones de tercero contra la futura sentencia. También en esa hipótesis, por lo común se hará primeramente el llamamiento (si no obstan dificultades de formas o de términos), después verá el juez ( a posteriori causa cognita) si admitir o no admitir (y en esta última hipótesis excluir)" ${ }^{133}$.

Relata cual es la posición del tercero después de haberse producido la convocatoria: "El llamado en causa, por solo hecho de haber sido citado, se encuentra constituido en la situación procesal de demandado (in ius vocatio) de manera que si no se constituye habrá que declararlo contumaz, como si hubiese sido citado desde el comienzo"134 y hasta donde llegan sus posibilidades de actuación que deduce del art.271, "podrá el llamado adoptar actitud de resistencia por razones de ritos o de fondo y pedir la exclusión, o bien adherirse a una u otra parte principal, o tomar él mismo posición de parte autónoma y principal, o por el contrario, declarar que se desinteresa y se remite a la justicia. Ello dependerá de las razones y del fundamento del llamamiento, así como del interés que pueda tomar este nuevo sujeto en la causa pendiente. De todos modos podrá él adoptar conclusiones prejudiciales de mérito" "135 así como la reacción de las otras partes: “Todas las demás partes, a su vez, podrán replicar si fuere del caso, y la sustanciación de la causa se desenvolverá en adelante como si desde el comienzo hubiera habido pluralidad de partes en el proceso" ${ }^{\text {"136. }}$.

\footnotetext{
${ }^{133}$ Redenti Enrico. Obra citada, pg 242.

${ }^{134}$ Redenti Enrico. Obra citada,pg 451

${ }^{135}$ Redenti Enrico. Obra citada, pg 452.

${ }^{136}$ Redenti Enrico. Obra citada, pg 452.
} 
Explica Liebman que el problema real provocado por la latitud y el carácter genérico de la letra legal, consiste en establecer en qué casos puede intervenir el tercero por ser común la causa y qué papel asume en el proceso. Para ello señala que la parte citante debe tener un interés en la citación que en definitiva tendrá viabilidad en casos de conexidad objetiva (objeto y título) o de prejudicialidad entre la relación que justifica el llamado y la que se discute. Sigue la posición de Calamandrei en cuanto a la caracterización del tercero como parte limitada frente a la demanda de certeza que al llamarlo instaura a su respecto la parte citante, con lo cual la sentencia tendrá efecto contra el llamado con referencia a los puntos de hecho y de derecho que sean comunes ${ }^{137}$.

Para Micheli la causa es común cuando el tercero es "titular de una situación jurídica conexa con aquella que es objeto del juicio, hasta el punto de tener comunes con esta última el petitum y la causa petendi”. Quedan excluidos los casos en los que el tercero estuviese habilitado para intervenir por adhesión y también cuando no hay identidad entre los dos elementos objetivos referidos. Sostiene, que con el llamamiento el tercero se convierte en parte aun cuando contra él no se hayan formulado demandas ni él las formule respecto de las partes de la causa. Señala que la citación en garantía, mencionada como una de las dos vertientes que presenta el art.106 CPC Italia, marca la diferenciación existente con la simple denuncia de litis porque a través de aquélla, el citante propone contra el garante una demanda de resarcimiento, anticipada y condicionada a que resulte perdedor en el juicio en el que produce el llamamiento ${ }^{\mathbf{1 3 8}}$.

\footnotetext{
${ }^{137}$ Liebman Enrico Tullio.Manuale di Diritto Processuale Civile. Ristampa inalterata Della seconda edizione.T.I,pgs 155 a 157.Dott. A.Guiffré Editore. Milano. 1968

${ }^{138}$ Micheli Gian Antonio.Obra citada,pgs 234 y 235.
} 
Proto Pisani comienza por señalar el problema que significa interpretar el significado de la expresión comunidad de causa ("comunanza di causa") dada su extrema equivocidad ;señala sin embargo que tales términos se refieren a casos en los que existe conexión objetiva, sea por identidad de petitum o por alternatividad, por identidad de título, por ambos motivos a la vez, por ser el tercero titular de un derecho jurídicamente dependiente del objeto del proceso en el que se llama ${ }^{\mathbf{1 3 9}}$.

Refiriéndose en concreto al concepto de causa común previsto por el art.106, Hugo Rocco, dice que éste se da cuando la relación sustancial que se discute entre el actor y el demandado sea conexa con la del tercero "por identidad de título o de sujeto o del uno y del otro", de modo que éste hubiese podido ser actor o demandado en un juicio separado. Refiriéndose a la calidad procesal del tercero derivada de la citación, dice que es la de parte, "puesto que el llamador, con su instancia, viene a desplegar conclusiones también en relación a él, mientras que por su parte el llamado puede adoptar conclusiones frente a las partes en causa"140.

En el pensamiento de Satta, el problema básico es el de determinar si el llamamiento importa una formación típica o por el contrario no es sino la proposición de una demanda "en relación a una persona cuando ya está pendiente un juicio sobre otros sujetos". Afirma que no le parece que el art.106 considera el caso de una proposición de demanda, sino el de la sustentación de una "pretensión de comunidad" de la controversia que la parte afirma con relación al tercero; el llamado importa articular una cuestión de legitimación (exclusiva o no) planteada como medio de defensa

\footnotetext{
${ }^{139}$ Proto Pisani Andrea.Lizioni di Diritto Processuale Civile.pgs 418 y 419.Jovene Editore .Nápoli.1994.

${ }^{140}$ Rocco Ugo.Obra citada T.II,pgs132 y 133.
} 
del citante que configura en lo sustancial una situación inversa a la de la intervención ad excludendum. Considera que no obstante que la ley autoriza a pedir la citación a ambas partes, ella es propia del demandado ya que para el actor es normalmente una extensión de la demanda ${ }^{141}$.

\section{España}

En la antigua legislación castellana se encuentran referencias a la intervención de terceros en defensa de sus bienes ejecutados "diziendo algunos que eran fuyas, o que auian derecho en ellas, e non de aquel cótra quien fue dada la fentécia" ${ }^{142}$.De allí nace, posiblemente, la idea peninsular de vincular la intervención de terceros con el embargo y ejecución de bienes y la clásica configuración de los procesos de tercería de dominio y de mejor derecho.

También los prácticos se ocupan del tema terceros, aunque solamente lo analizan en tanto configure un ingreso voluntario, sin que aparezca la idea de alguien que arriba por iniciativa de las partes o del juez. Así el Conde de la Cañada, luego de criticar la poca claridad con la que lo tratan Covarrubias y Suárez de Figueroa la cuestión del "tercero opositor", se lanza a similar tarea. El autor explica la razón de aquella denominación indicando que es opositor pues viene al juicio a oponerse necesariamente, por un lado, a la posición de actor o reo o por otro, a la de las dos partes.

\footnotetext{
${ }^{141}$ Satta Salvatore. Obra citada....V.1.pg 95.

${ }^{142}$ Partida tercera,Título 27,ley III
} 
De acuerdo a ello el tercero será opositor coadyuvante $u$ opositor excluyente respectivamente. ${ }^{143}$.

Febrero llama tercero opositor al sujeto que se opone a la ejecución ya sea solicitando ser preferido al ejecutante o alegando ser suyos o tener derechos con relación a los bienes ejecutados. Agrega que "los autores" distinguen tres clases de dichos terceros: los coadyuvantes del derecho del ejecutante, los que lo son del ejecutado y los que intentan excluir al actor y al reo ${ }^{144}$.

Vicente y Caravantes explica que en tanto el tercero ingresante en un proceso lo hace oponiéndose a la pretensión de alguno de los litigantes originarios, pasa a llamarse tercero opositor. El ingreso puede producirse tanto en los juicios ordinarios como en los ejecutivos y pueden encontrarse dos clases de opositores excluyentes: los coadyuvantes con interés coincidente con alguno de los litigantes y los excluyentes con derecho opuesto a los de actor y demandado y que se distinguen según sean de dominio o de mejor derecho. Los opositores coadyuvantes al no ser

\footnotetext{
${ }^{143}$ Conde de la Cañada. Instituciones de los juicios civiles, así ordinarios como extraordinarios, en todos los trámites según que se empiezan, continúan y acaban en los tribunales reales. Observaciones prácticas sobre los recursos de fuerza; modo y forma de introducirlos, continuarlos y de terminarlos en los tribunales Superiores. T.1 pg 181 Tercera edición. Compañía General de Impresores y Libreros del Reino. Madrid. 1845. Primera edición 1794.

${ }^{144}$ Febrero Novísimo o Librería de Jueces, Abogados, Escribanos y Médicos Legistas por don Eugenio de Tapia, Tomo III,pg.611. Nueva Edición. Librería de Lecointe. Paris 1845
} 
verdaderos opositores por no tener sino el mismo interés que las partes originarias se identifican y unen con aquéllos con los que coadyuvan ${ }^{145}$.

En Reus puede leerse una crítica a la distinción entre tercerías excluyentes y coadyuvantes, fundada en que cuando un tercero se presenta en un litigio sosteniendo las mismas pretensiones que cualquiera de los otros dos, procede de acuerdo a la ley que se una a quien trata de ayudar y que unidos litiguen bajo la misma dirección. En esas condiciones se sostiene que no habrá tercería sino pleito de uno contra dos, ya que para que exista tercería es menester que el tercero litigue en un juicio ya promovido haciendo oposición a los litigantes originarios. Se sostiene que basta con que se haya producido embargo de bienes para que pueda haber tercería tanto en los juicios ejecutivos como en los demás. En consecuencia se reclama que todas las tercerías sean tratadas en un título específico ${ }^{146}$.

Las leyes de enjuiciamiento españolas, no regularon ninguna modalidad de intervención de terceros en juicios de conocimiento; consagran en cambio las tercerías de dominio o de mejor derecho o preferencia. La doctrina y la jurisprudencia se ocuparon de cubrir el vacío normativo. ${ }^{147}$ Con respecto a la acción de garantía, ver punto 2 .

\footnotetext{
${ }^{145}$ Vicente y Caravantes José de, Tratado Histórico, Critico Filosófico de los Procedimientos Judiciales en Materia Civil según la nueva Ley de Enjuiciamiento, pg 332,T.III, Imprenta de Gaspar y Roig Editores. Madrid. 1856.

${ }^{146}$ Ley de Enjuiciamiento Civil del 3 de febrero de 1881.Concordada y anotada con gran extensión según la doctrina de los autores y la Jurisprudencia del Tribunal Supremo, por la Redacción de la Revista General de Legislación y Jurisprudencia, bajo la dirección de Emilio Reus, Segunda edición, tomo III.pg. 762. Madrid. Hijos de Reus. Editores. 1909.

${ }^{147} \mathrm{Al}$ respecto, Manuel Serra Domínguez ,Intervención de terceros en el proceso, Obra citada,pg.207;Davila Millán María E. Litisconsorcio necesario. Concepto y tratamiento procesal,pgs 38 y 39. Bosch Casa editora.A.Barcelona.1975.Montero Aroca Juan .
} 
La 1/2000, actual Ley de Enjuiciamiento Civil contempla la existencia de dos formas de ingreso: la de tipo voluntario, identificada como intervención de sujetos originariamente no demandantes o demandados (art. 13) y la provocada (art.14) capaz de producir sucesión procesal en ciertos casos (art.18).A ello se le suma la posibilidad de decretarse citación oficiosa, preventiva de proceso fraudulento (art.150) ${ }^{\mathbf{1 4 8}}$.

Acumulación de proceso y proceso único con pluralidad de partes. Revista Argentina de Derecho Procesal n03.Julio-Septiembre 1972.pg.395. La Ley .Buenos Aires

${ }^{148}$ Ley de Enjuiciamiento Civil.

Art.13. Intervención de sujetos originariamente no demandantes ni demandados. I. Mientras se encuentre pendiente un proceso, podrá ser admitido como demandante o demandado, quien acredite tener interés directo y legítimo en el resultado del pleito.

En particular cualquier consumidor o usuario podrá intervenir en los procesos instados por las entidades legalmente reconocidas para la defensa de los intereses de aquéllos.

2. La solicitud de intervención no suspenderá el curso del procedimiento. El tribunal resolverá por medio de auto, previa audiencia de las partes personadas en el plazo común de diez días.

3. Admitida la intervención, no se retrotraerán las actuaciones, pero el interviniente será considerado parte en el proceso a todos los efectos y podrá defender las pretensiones formuladas por su litisconsorte o las que el propio interviniente formule, si tuviere oportunidad procesal para ello, aunque su litisconsorte renuncie, se allane, desista o se aparte del procedimiento por cualquier otra causa.

También se permitirán al interviniente las alegaciones necesarias para su defensa, que no hubiere efectuado por corresponder a momentos procesales anteriores a su admisión en el proceso. De estas alegaciones se dará traslado, en todo caso, a las demás partes, por plazo de cinco días.

El interviniente podrá, asimismo, utilizar los recursos que procedan contra las resoluciones que estime perjudiciales a su interés, aunque las consienta su litisconsorte."

"Art.14. Intervención provocada. I. En caso de que la ley permita que el demandante llame a un tercero para que intervenga en el proceso sin la calidad de demandado, la solicitud de 
intervención debe realizarse en la demanda, salvo que la ley disponga expresamente otra cosa. Admitida por el tribunal la entrada en el proceso del tercero, este dispondrá de las mismas facultades de actuación que la ley concede a las partes.

Cuando la ley permita al demandado llamar a un tercero para que intervenga en el proceso, se procederá conforme a las siguientes reglas.

$1^{\circ}$.El demandado solicitará al tribunal que sea notificada al tercero la pendencia del juicio. Las solicitud deberá presentarse dentro del plazo otorgado para contestar a la demanda o, cuando se trate de juicio verbal, antes del día señalado para la vista.

$2^{\circ}$. El tribunal oirá al demandante en el plazo de diez días y resolverá mediante auto lo que proceda. Acordada la notificación, se emplazará al tercero para contestar la demanda en la misma forma y en idénticos términos a los establecidos para el emplazamiento del demandado. Si se tratase de un juicio verbal, el tribunal por medio de providencia hará nuevo señalamiento para la vista, citando a las partes y al tercero llamado al proceso.

$3^{\circ}$. El plazo concedido al demandado para contestar a la demanda quedará en suspenso desde la solicitud a que se refiere la regla $1^{\mathrm{a}}$ y se reanudara con la notificación al demandado para la desestimación de su petición, o, si es estimada, con el traslado del escrito de contestación presentado por el tercero y, en todo caso, al expirar el plazo concedido a este último para contestar la demanda.

$4^{\circ}$. Si comparecido el tercero, el demandado considerare que su lugar en el proceso debe ser ocupado por aquél, se procederá conforme a lo dispuesto en el artículo 18."

"Art.18. Sucesión en los casos de intervención provocada. En el caso a que se refiere la regla $4^{\mathrm{a}}$ del apartado $2^{\circ}$ del artículo 14, de la solicitud presentada por el demandado se dará traslado por el Secretario la ley Judicial a las demás partes para que aleguen lo que a su derecho convenga, por plazo de cinco días, decidiendo a continuación el Tribunal por medio de auto, lo que resulte procedente en orden a la conveniencia o no de la sucesión.

Art .150. Notificación de resoluciones y diligencias de ordenación. 1. Las resoluciones procesales se notificarán a todos los que sean parte en el proceso.

2. Por disposición del Tribunal, también se notificará la pendencia del proceso a las personas que, según los mismos autos, puedan verse afectadas por la resolución que ponga fín al procedimiento. Esta comunicación se llevará a cabo con los mismos requisitos, cuando el Tribunal advierta indicios de que las partes están utilizando el proceso con fines fraudulentos. 
Con respecto al sistema vigente, la doctrina señala que la ley utiliza la denominación "intervención provocada", en lugar de obligada, coactiva o forzosa. A la vez, la forma en que la norma diferencia los casos de procedencia por iniciativa del actor de los que puede promover el demandado. En general se entiende que el campo de los primeros más bien se corresponde con supuestos de obligaciones legales tales como las citaciones impuestas al demandante co-titular o concesionario de licencia por leyes de marcas y patentes respectivamente, para el conocimiento y participación en el juicio de otro co-titular o titular de patente. En cuanto al demandado, se precisa que solo se le permite citar si la ley lo autoriza, por lo cual se considera que ello puede darse por tres motivos: a) comunidad de causa b) llamada en garantía-referida a la evicción- y c)llamamiento al tercero pretendiente o nominatio auctoris. ${ }^{149}$ Se señala también que la LEC no otorga específicamente condición de parte a los terceros de la intervención provocada, a diferencia de la que el art.14 concede a los intervinientes voluntarios. No obstante, debe de considerársele como parte $^{150}$.

3. También se hará notificación a los terceros en los casos en que lo prevea la ley

${ }^{149}$ Larrosa Amante Miguel Angel. Las partes problemática procesal ,pgs 123 a 130. Consejo General del Poder Judicial. Cuadernos de Derecho Judicial XIX-2005.Madrid; Samanes Ara Carmen. Las partes en el proceso civil.,pgs 142 a 146 .La Ley. Madrid .2000 .

150 "En el art.14 no se reitera la aseveración hecha en el artículo anterior, según la cual el interviniente es parte. Pero creo que tal es, también para ese caso, la voluntad del legislador, pues en este punto no puede haber diferencia en función de quién tome la iniciativa de la intervención, y además se expresa que el emplazamiento que se hace al tercero para contestar la demanda en la misma forma y en idénticos términos a los establecidos para el emplazamiento del demandado" (Samanes Ara Carmen. Obra citada, pg. 145 y 146) 
SECCION TERCERA

\section{DERECHO SUDAMERICANO}

\section{Bolivia}

El Código de Procedimiento Civil de Bolivia, anterior al vigente, regula la citación de evicción (arts.75 a 78) y las que denomina tercerías coadyuvantes (voluntarias, excluyentes y de derecho preferente, arts 365 a 369). No se refiere, en cambio, a la intervención obligada. Parada Mendía trata brevemente a la intervención provocada, ejemplificándola en los arts.624 (demanda simultánea contra inquilinos y subinquilinos), 625 (tramitación) y 627 (apelación) y 335.5 (entre los requisitos de la demanda, pedir citación de evicción) ${ }^{151}$. El nuevo Código Procesal Civil -Ley 439 del 19 de noviembre 2013, con vigencia plena a partir del 6 agosto de 2015parte de la existencia de dos tipos de intervenciones: voluntarias y forzosas. La segunda comprende, la citación de evicción (art.59), llamamiento en causa en los casos de controversia común o a quien pudiera afectar la sentencia (art.60) y denuncia del verdadero poseedor o propietario $(\operatorname{art} .61)^{152}$.

\footnotetext{
${ }^{151}$ Parada Mendía Alex. El tercero en el proceso civil, pg.73.IvrisTantvm. Santa Cruz de la Sierra.2009.

152 ARTíCULO 59. (EFECTOS DE LA CITACIÓN).Si la citada o el citado de evicción no compareciere o, habiendo comparecido, no asumiere defensa por la parte que solicitó la citación, el proceso continuará contra este último, salvo sus derechos contra aquel.
}

Si la citada o el citado compareciere, tomará la causa en el estado en que se encuentre. 


\section{Brasil}

I.Si la sentencia causare perjuicio a la parte demandada, en ejecución de fallos, se liquidará por la vía incidental los daños y perjuicios ocasionados por el enajenante conforme a las normas del Código Civil.

II.En uno u otro supuesto, la autoridad judicial, en un plazo de cinco días, convocará a audiencia, en la que, escuchando a las partes, dictará auto interlocutorio que podrá ser:

1. Declarativo de la procedencia del llamamiento, en cuyo caso el proceso continuará contra la parte demandada y la citada o el citado con el carácter de litisconsorte.

2. Desestimatorio del llamamiento, debiendo proseguir la causa contra el principal, cuyos derechos quedarán salvados para que los haga valer contra su enajenante.

Contra el auto interlocutorio procederá únicamente el recurso de apelación en efecto devolutivo.

ARTÍCULO 60. (LLAMAMIENTO EN CAUSA DE UN TERCERO).

La parte demandada en el plazo previsto para la contestación, podrá solicitar la citación de un tercero, a quien se considere que la controversia le es común o a quien la sentencia pudiere afectar. El citado no podrá objetar la citación y comparecerá con los mismos derechos y deberes de la parte demandada.

ARTÍCULO 61 (DENUNCIA DE TERCERO).

Se produce cuando promovida la demanda contra el que posee una cosa ajena, la parte demandada denuncia el nombre y domicilio del poseedor o propietario, bajo responsabilidad de daños y perjuicios en caso de omisión, a fin de que el proceso continúe con éste. La parte actora una vez conocida la denuncia formulada por la parte demandada, debe dirigir la demanda contra el poseedor o propietario, permitiendo la exclusión de la parte demandada original, de lo contrario su demanda deberá ser rechazada por falta de legitimación 
El CPC Brasil regula diversos institutos que comprendidos en la temática que abordamos. Así, lo hace con la denuncia del autor ("Da nomeaçao à autoria)-arts 62 a 69-,la denuncia de litis ("Da denunciaçao da lide") -arts 70 a 76- y el llamamiento al proceso (Do chamamento ao processo)- arts 77 a $80^{153}$.

153 “La nominación de autoría.

Art.62.Aquél que detente la cosa en nombre ajeno, siéndole demandada en nombre propio, deberá nombrar la autoría o al propietario o al poseedor.

Art.63. Aplicase también lo dispuesto en el artículo antecedente a la acción de indemnización, intentada por el propietario o por el titular de un derecho sobre la cosa, toda vez que el responsable por los perjuicios alegara que practicó el acto por orden o en cumplimiento de instrucciones de tercero.

Art.64. En ambos casos, el demandado requerirá la nominación en el plazo para la defensa; el juez al admitir el pedido, suspenderá el proceso o mandará concurrir al autor en el plazo de cinco ( 5) días.

Art.65.Aceptando el nominado, incumbe al actor promoverle citación. Recusándolo quedará sin efecto la nominación.

Art.66. Si el nominado reconociese la calidad que le es atribuida, el proceso correrá contra él.; si la negara el proceso continuará contra el nominante.

Art.67. Cuando el actor recusara al nominado o cuando éste negara la calidad atribuida, se asignará al nominante nuevo plazo para contestar.

Art.68. Presúmese aceptada la nominación si

I. El actor no requirió nada en el plazo en el que le correspondía manifestarse.

II. El nominado no comparece o compareciendo guarda silencio.

Art.69. Responderá por pérdidas y daños aquél a que incumbía la nominación. 
I. Dejando de nominar la autoría cuando le competía hacerlo.

II. Nominando a persona diversa de aquélla en cuyo nombre detente la cosa demandada.

La denuncia de Litis.

Art.70.La denuncia de litis es obligatoria:

I. Al enajenante, en la acción en la que el tercero reivindica la cosa cuyo dominio fuera transferido a la parte, a fin de que ésta pueda ejercer el derecho que le resulta de la evicción.

II. Al propietario o al poseedor indirecto, cuando, por fuerza de la obligación o del derecho, en casos como el de usufructuario, acreedor pignoraticio, locatario o demandado citado en nombre propio, ejerza la posesión directa de la cosa demandada.

III. A quien estuviese obligado por la ley o por el contrato, a indemnizar en acción regresiva o perjuicio de perder la demanda.

Art.71. La citación del denunciado será requerida juntamente con la del demandado si el denunciante fuera el actor; en el plazo para contestar, si el denunciante fuese el demandado.

Art.72. Ordenada la citación quedará suspendido el proceso.

Pgfo $1^{\circ}$. La citación del enajenante, propietario, poseedor indirecto o del responsable por la indemnización se hará.

a) cuando residiera en la misma comarca dentro de diez (10) días”.

b) cuando residiera en otra comarca, o en lugar incierto, dentro de treinta (30) días.

Pgfo $2^{\circ}$. De no procederse a la citación en el plazo marcado, la acción proseguirá únicamente en relación al denunciante”

Art.73. A los fines de lo dispuesto en el art.70, el denunciado, por una vez intimará litigio al enajenante o propietario, o poseedor indirecto o al responsable por la 
indemnización, y así sucesivamente, observándose en cuanto a los plazos, lo dispuesto en el artículo precedente.

Art.74. Efectuada la denuncia por el actor, el denunciado, compareciendo, asumirá la posición de litisconsorte del denunciante y podrá adherir a la petición inicial, procediéndose en seguida a la citación del demandado.

Art.75. Hecha la denuncia por el demandado:

I .Si el denunciado aceptara y contestara el pedido, el proceso proseguirá entre el actor por un lado, y por otro, como litisconsorte, el denunciante o el denunciado.

II. Si el denunciado fuese rebelde, o compareciese solo para negar la cualidad que le fuera atribuida, corresponderá al denunciante proseguir la defensa hasta el final.

III. Si el denunciado confesara los hechos alegados por el actor, podrá el denunciante seguir en la defensa.

Art.76. La sentencia que juzgara procedente la acción, declarará según el caso, el derecho de evicción o las responsabilidades por pérdidas y daños, valiendo como título ejecutivo.

El llamamiento al proceso.

Art 77 Es admisible al llamamiento al proceso:

I-Del deudor en la acción en la que el fiador fuera demandado.

II- De otros fiadores, cuando en la acción hubiese sido citado solamente uno de ellos.

III. De todos los deudores solidarios, cuando el acreedor exigió de uno o de alguno de ellos, parcial o totalmente, la deuda común.”

Art.78. Para que el juez declare, en la misma sentencia, las responsabilidades de los obligados, a la que se refiere el artículo precedente ,el demandado requerirá, en el plazo para contestar, la citación de llamado". 
La denuncia de autor o nominación de autoría presupone la existencia de una acción relativa a un bien mueble o inmueble, aun cuando pueda tener su origen en una acción personal de tipo indemnizatorio como resulta del art.63. Con este instituto se busca corregir la legitimación pasiva ya que quien es demandado- cuando solamente es un mero detentador de la cosadenuncia al verdadero titular de la relación jurídica material en cuestión, señalando a la persona de la que inmediatamente deriva su situación. De tal manera no es admisible el per saltum destinado a llamar a otro antecesor con el que no resulte un vínculo directo. El actor puede o no aceptar al nominado; si hace lo primero, deberá demandarlo específicamente; en caso contrario, la acción seguirá contra el primitivo demandado. A su vez, el nominado puede o no aceptar la legitimación que le atribuye el demandado; si la acepta y media conformidad del actor, el demandado queda liberado del proceso. Si no la admite, cosa que debe manifestar expresamente pues de lo contrario se presume la aceptación (art.68), podrá oponerse al actor planteando su falta de legitimación pasiva. Es obligatorio para el demandado producir la nominación bajo consecuencias de daños y perjuicios (art.69) ${ }^{154}$.

La denuncia de litis es la manera de traer al litigio a un tercero (litisdenunciado) buscando eliminar acciones regresivas futuras en las

“Art.79. El juez suspenderá el proceso, mandando observar, en cuanto a la citación y a los plazos, lo dispuesto en los artículos 72 a 74.

“Art.80. La sentencia que juzgara procedente la acción condenando a los deudores, valdrá como título ejecutivo, en favor de quien satisfaciera la deuda, para exigirla por entero al deudor principal, o a cada uno de los codeudores su cuota, en la proporción que les tocare".

${ }^{154}$ Arruda Alvim Manuel .Manual de Directo Processual Civil.Vol II, pgs 155 a 161. $6^{\text {a ed. }}$ San Pablo. 1997 
cuales ese tercero sería demandado. De tal manera, su responsabilidad frente al citante, será juzgada -por acción regresiva eventualmente considerada- dentro del mismo proceso y por la misma sentencia. Se hace necesario que, para poder practicar la denuncia, el demandado deba ser parte legítima pasiva. El autor que venimos siguiendo, ejemplifica al respecto estableciendo que si aquél, frente a una demanda por un accidente de tránsito sustenta falta de legitimación pasiva por haber enajenado el rodado antes del evento, no puede, simultáneamente, llamar al adquirente del vehículo. El denunciado puede en cambio ser litisconsorte pasivo que ya se encuentre en el proceso y que entonces responderá en los límites de la demanda al tiempo que lo hará en los términos del llamamiento ${ }^{\mathbf{1 5 5}}$.

La hipótesis marcada por el art.70 I, doctrinariamente aparece edificada en torno de la evicción, y apunta a hacer del tercero un litisconsorte al que le pueda alcanzar la sentencia ,si bien la acción que le compete tiene condición de eventual, pues solamente tendrá resultado positivo si el litisdenunciante perdiese aquélla de la que resulta ser sujeto pasivo. El citado no deberá operar ya como parte al momento del llamamiento, pues entonces perderá sentido la convocatoria. La obligatoriedad del llamamiento de la que habla la ley debe ser entendida como condición cuyo incumplimiento hará perder la garantía debida por el tercero $^{156}$.

El art.70 II se refiere a la nominación de autoría ,pero importa también la posibilidad de que en el mismo proceso se resuelva la eventual

\footnotetext{
${ }^{155}$ Arruda (Alvim Manuel Obra y tomo citados, pgs 164 y 165.

${ }^{156}$ Arruda Alvim Manuel Obra y tomo citados, pgs 171 a 175
} 
acción de regreso que el citante pueda tener contra el citado por los perjuicios que le cause el pleito ${ }^{157}$.

El art.70 III se aplica a supuestos en los que el citado se encuentre obligado por ley o por contrato a indemnizar en una acción regresiva al que perdiere el juicio, sea actor o demandado. Se dan ejemplos tales como el llamado al asegurador, o el que puede formular el Estado con referencia al funcionario responsable del acto por cuyas consecuencias se litiga ${ }^{158}$.

El nuevo Código de Processo Civil -ley 13105/2015 del 16/3/2015con vigencia al año de su publicación, dedica el Título I -Secciones II y III- del Capítulo V del Libro II a la intervención de terceros. La Sección primera contempla la figura del amicus curia (art.320) tema en realidad ajeno al que nos ocupa; la Sección segunda se refiere a la asistencia voluntaria (arts 321 a 326). Determina el ordenamiento que el interviniente será considerado asistente que en caso de rebeldía del asistido operará como su gestor de negocios y si la sentencia influyese en la relación jurídica entre él y el adversario del asistido se lo tendrá por litisconsorte de la parte principal (art.325). La Sección tercera se dedica al llamamiento al proceso (art.327) y al llamamiento en garantía $(\operatorname{art.331})^{\mathbf{1 5 9}}$.

\footnotetext{
${ }^{157}$ Arruda Alvim Manuel. Obra y tomo citados, pgs 174 y 175

${ }^{158}$ Arruda Alvim Manuel.Manual.Obra y tomo citados, pgs.181 y 182.

${ }^{159}$ Art.327. Es admisible el llamamiento al proceso pedido por el demandado:

I. Del afianzado en la acción en la que el fiador fuese demandado.

II. De los demás fiadores, en la acción propuesta contra alguno de ellos.
}

III. De los demás deudores solidarios cuando el acreedor exigiera de uno de ellos el pago de la deuda común. 


\section{Chile}

El Código de Procedimiento Civil de Chile considera la denuncia de litis (art.21) ${ }^{\mathbf{1 6 0}}$, la intervención voluntaria de terceros (art 22) y la

Art.328.La citación del llamado será hecha en el plazo de dos meses, suspendiéndose el proceso; finalizado el plazo sin que se efectivice la citación, el llamamiento quedará sin efecto.

Art.329 .La sentencia de procedencia condenará a todos los coobligados, valiendo como título ejecutivo a favor del que pagó la deuda, para exigirlo del deudor principal o de los codeudores por la cuota que le tocare a cada uno.

Art.300. También será admisible el llamamiento en garantía ,promovido por cualquiera de las partes:

I. Del enajenante, en la acción en que se reivindica la cosa cuyo dominio fue transferido por éste a la parte.

II. De aquél que estuviese obligado por ley o por contrato a indemnizar en acción regresiva, el perjuicio de la parte vencida.

Art.331. La citación del llamado en garantía será requerida por el actor ,en conjunto con el demandado o por éste ,en el plazo de contestación, debiendo ser realizada en el plazo del art.328.

Art.332.La sentencia de juzgar procedente la acción decidirá también sobre la responsabilidad del llamado.

${ }^{160}$ Art.21. Si la acción ejercida por alguna persona corresponde también a otra u otras personas determinadas, podrán los demandados pedir que se ponga la demanda en 
intervención excluyente (art 22). Además la citación de evicción es tratada en los arts 584 a 587.

El proyecto de Código Procesal Civil presentado al Congreso por mensaje 399-357 del 18/5/2009, en su art.19 considera como partes a los litigantes originarios y a los terceros. Conceptualiza al litisconsorcio facultativo, estableciendo que dos o más personas pueden litigar en forma conjunta, activa o pasivamente, si sus pretensiones son conexas por causa u objeto de manera que la producción de pruebas sea un fin común para ellas o que la sentencia dictada con respecto a una pueda afectar a la otra. Como principio general los litigantes en tales condiciones serán considerados, como litigantes independientes y sus actos no afectan ni favorecen a los restantes litisconsortes. Se contempla la intervención voluntaria en el art.38 sobre la base de la existencia de un interés actual. La solicitud de intervención en ningún caso suspenderá el trámite de la causa y podrá plantearse en la primera instancia hasta la audiencia preliminar o excepcionalmente hasta la de juicio oral, pero aceptando lo actuado hasta entonces. La denuncia de litis se contempla en el art.39, mejorando los conceptos del artículo 21 vigente $^{161}$.

conocimiento de los que no hayan ocurrido a entablarla, quienes deberán expresar en el término de emplazamiento si adhieren a ella.

Si las dichas personas se adhieren a la demanda, se aplicará lo dispuesto en los artículos 12 y 13; si declaran su resolución de no adherirse caducará su derecho; y si nada dicen dentro del término legal, les afectará el resultado del proceso, sin nueva citación. En este último caso podrán comparecer en cualquier estado del juicio, pero respetando todo lo obrado con anterioridad.

${ }^{161}$ Denuncia de litis. Si la pretensión ejercida en un proceso judicial corresponde de también a otro u otros sujetos determinados que no han comparecido en dicho proceso, el tribunal ordenará, de oficio o a petición de parte que se ponga la demanda en conocimiento de 
En el año 2012, el Poder Ejecutivo presentó al Congreso un nuevo proyecto en el que también los terceros son considerados parte (art.15):se admite la intervención de terceros en distintas calidades: así, la de coadyuvantes o adhesivos, la de terceros independientes y la de terceros excluyentes (art.37).Pertenece a la primera, quien justifique tener un interés actual; toma la causa en el estado que tenga al tiempo de su intervención ,a menos que acredite fraude o colusión. Su ingreso se plantea por vía incidental y sin que produzca suspensión del trámite principal (art.38).El tercero independiente es-según nuestro criterio-el que puede accionar por el mismo título o causa por el que acciona el sujeto al que adhiere y con el cual formará litisconsorcio (art.36). Según la letra legal (art.39), tanto los terceros independientes como los excluyentes deberán plantear una demanda -adecuadamente fundada so riesgo de ser declarada inadmisible si muestra manifiesta falta de fundamentos o puede sustanciarse separadamente sin grave perjuicio al tercero- contra ambos litigantes originarios. Pese a la letra del art.39 entendemos que para los terceros

aquéllos, de quienes deberán expresar se adhieren o no a ello. Para estos efectos el tribunal citará a una audiencia especial a la que deberán concurrir las partes y los sujetos, debidamente representados, cuya intervención ha sido requerida.

Si dichos sujetos adhieren a la demanda, conformarán con él o los primitivos actores un litisconsorcio que se ajustará a las normas dadas para ésta última figura. $\mathrm{Si}$ optan por no adherirse deberán hacer reserva acerca de sus derechos.

Si nada dicen les afectará el resultado del proceso. De tal manera, el citado podrá concurrir al proceso como interviniente adhesivo y en litisconsorcio con el adherido, conforme lo dispuesto por el art.37.

El art.40 regula la intervención excluyente, por la cual el tercero, en defensa de su derecho, deberá demandar a las partes originarias considerando a ambas como demandados. 
independientes la demanda se dirigirá solamente contra la contraparte del adherido por lo que la demanda contra actor y demandado solo será viable para los excluyentes, actividad que solamente podrán hacer hasta antes de la audiencia preliminar y que provocará la suspensión del procedimiento hasta que se resuelva acerca de la admisibilidad de la presentación. El mismo art.39 dispone en su parte final y sin discriminar entre independientes y excluyentes, la igualdad procesal entre terceros y partes "principales". ${ }^{162}$ La denuncia de litis, que abre las puertas a una intervención está prevista en el art.40 $0^{163}$.

\section{Colombia}

El Código de Procedimiento Civil de Colombia en su versión inmediatamente anterior a la vigente-aparte de las intervenciones de tipo voluntario- regula la denuncia de litis (art.54), la citación en garantía

\footnotetext{
162 "Art.39. Intervención de otros terceros, tercera parte. El tercero cuya intervención haya sido admitida tendrá los mismos derechos, facultades y deberes que las partes principales del proceso, debiendo respetar todo lo obrado con anterioridad

${ }^{163}$ Art.40. Comunicación de la litis. Por disposición del tribunal, se notificará la pendencia del proceso a las personas que, según los mismos autos, pueden verse afectadas por la sentencia que en su momento se dictare. Esta comunicación se llevará a cabo, con los mismos requisitos, cuando el tribunal advierta indicios de que las partes están utilizando el proceso con fines fraudulentos.
}

También se hará la notificación al tercero en los casos en que lo prevea la ley. 
(art.57), el llamamiento de oficio en caso de fraude o colusión (art.58) y el llamamiento al poseedor o tenedor (art.58) ${ }^{\mathbf{1 6 4}}$.

${ }^{164}$ Art.54. Denuncia del pleito. Quien de acuerdo con la ley sustancial tenga derecho a denunciar el pleito que promueva o que se le promueva, deberá ejercitarlo en la demanda o dentro del término para contestarla, según el caso.

Al escrito de denuncia acompañará la prueba siquiera sumaria del derecho a formularla y relativa a la existencia y representación que fueren necesarias.

El denunciado en un pleito tiene a su vez facultad para denunciarlo en la misma forma que el demandante o demandado".

Art.55. Requisitos de la denuncia. El escrito de denuncia deberá contener:

1. El nombre del denunciado y el de su representante si aquél no puede comparecer por sí al proceso.

2.La indicación del domicilio del denunciado, o en su defecto, de su residencia, y la de su habitación u oficina y los de su representante, según fuere el caso, o la manifestación de que se ignoran, lo último bajo juramento, que se entiende prestado por la sola presentación del escrito.

3. Los hechos en que se basa la denuncia y los fundamentos de derecho que se invoquen.

Art.56. Si el juez hallare procedente la denuncia, ordenará citar al denunciado y señalará un término de cinco días para que intervenga en el proceso; si no residiera en la sede del juzgado, el término se aumentará hasta por diez días. El auto que acepte o niegue la denuncia es apelable.

La citación se hará mediante la notificación del auto que aceptare la denuncia, en la forma establecida para el admisorio de la demanda, y el proceso se suspenderá desde la admisión de la denuncia hasta cuando se cite al denunciado y haya vencido el término para que éste comparezca; la suspensión no podrá exceder de noventa días. El 
denunciado podrá presentar en un solo escrito contestación a la demanda y a la denuncia, y en el mismo, solicitar las pruebas que pretenda hacer valer.

Surtida la citación, se considerará al denunciado litisconsorte del denunciante y tendrá las mismas facultades de éste.

En la sentencia se resolverá, cuando fuere pertinente, sobre la relación sustancial que exista entre denunciante y denunciado, y acerca de las indemnizaciones o restituciones a cargo de éste.

Art.57. Llamamiento en garantía. Quien tenga derecho legal o contractual de exigir a un tercero la indemnización del perjuicio que llegare a sufrir, o el reembolso total o parcial del pago que tuviere que hacer como resultado de la sentencia, podrá pedir la citación de aquél, para que en el mismo proceso se resuelva sobre tal relación. El llamamiento se sujetará a lo dispuesto en los dos artículos anteriores.

Art.58. Llamamiento ex officio. En cualquiera de las instancias, siempre que el juez advierta colusión o fraude en el proceso, ordenará la citación de las personas que pueden resultar perjudicadas, para que hagan valer sus derechos, y con tal fin suspenderá los trámites hasta por treinta días. Esta intervención se sujetará a lo dispuesto en los incisos cuarto y quinto del art.52.

Art.59. Llamamiento de poseedor o tenedor. El que teniendo una cosa a nombre de otro, sea demandado como poseedor de ella, deberá expresarlo así en la contestación de la demanda, indicando el domicilio o residencia y la habitación u oficina del poseedor, so pena de ser condenado en el mismo proceso a pagar los perjuicios que su silencio cause al demandante. El juez ordenará citar al poseedor designado y para estos efectos se aplicará lo dispuesto en el artículo 56.

Si el citado comparece y reconoce que es poseedor, se tendrá como parte en lugar del demandado, quien quedará fuera del proceso. En este caso el juez dará traslado de la demanda al poseedor, por auto que no requerirá notificación personal”. 
Según lo explica Parra Quijano en la materia tratada, el tema del alcance de la denuncia de litis en cuanto pudiera comprender la acción de garantía dio lugar a distintas interpretaciones: así para Morales Molina y la jurisprudencia de la Corte Suprema, solamente juega en los casos de evicción, es decir cuando existe garantía real por parte del enajenante. En cambio para Devis Echandía era posible usarla también en casos de garantías personales. El autor que seguimos, opina que en realidad la citación en garantía bien puede estar contenida en los términos del art.54 por lo que a su juicio el art.57 es superfluo ${ }^{\mathbf{1 6 5}}$.

Por ley 1561 del mes de julio 2012 rige un nuevo ordenamiento denominado Código General del Proceso. En el Libro Primero, se dedica el Capítulo II a los litisconsorcios, al llamamiento en garantía ,al llamamiento al poseedor; el Capítulo III está dedica a los Terceros. El nuevo ordenamiento soluciona las divergencias referidas ya que en su art.64-que viene a reemplazar al art.59 del anterior se especifica que el llamamiento en garantía ha de servir no solamente para los casos en los que el citante tuviera derecho a reembolso o indemnización por perjuicios

"Si el citado no comparece o niega su calidad de poseedor, el proceso continuará con el demandado, pero la sentencia surtirá sus efectos respecto de éste y del poseedor por él designado."

"Lo dispuesto en el presente artículo se aplicará a quien fuere demandado como tenedor de una cosa, si la tenencia radica en otra persona."

"Cuando en el expediente aparezca la prueba de que el verdadero poseedor o tenedor es otra persona, el juez de primera instancia de oficio ordenará su citación".

${ }^{165}$ Parra Quijano Jairo. La intervención de terceros en el proceso civil, pgs 198 a 204. Depalma. Buenos Aires. 1986 


\section{sufridos sino también al saneamiento por evicción. Se observa que en el llamamiento al poseedor o tenedor (art.67 que reemplaza al art.59), la ley prevé la imposición de multas al demandado que debió denunciarlos ${ }^{\mathbf{1 6 6}}$.}

\footnotetext{
${ }^{166}$ Artículo 64. Llamamiento en garantía. Quien afirme tener derecho legal o contractual a exigir de otro la indemnización del perjuicio que llegare a sufrir o el reembolso total o parcial del pago que tuviere que hacer como resultado de la sentencia que se dicte en el proceso que promueva o se le promueva, o quien de acuerdo con la ley sustancial tenga derecho al saneamiento por evicción, podrá pedir, en la demanda o dentro del término para contestarla, que en el mismo proceso se resuelva sobre tal relación.
}

Artículo 65. Requisitos del llamamiento. La demanda por medio de la cual se llame en garantía deberá cumplir con los mismos requisitos exigidos en el artículo 82 y demás normas aplicables.

El convocado podrá a su vez llamar en garantía.

Artículo 66. Trámite. Si el juez halla procedente el llamamiento, ordenará notificar personalmente al convocado y correrle traslado del escrito por el término de la demanda inicial. Si la notificación no se logra dentro de los seis (6) meses siguientes, el llamamiento será ineficaz. La misma regla se aplicará en el caso contemplado en el inciso segundo del artículo anterior.

El llamado en garantía podrá contestar en un solo escrito la demanda y el llamamiento, y solicitar las pruebas que pretenda hacer valer.

En la sentencia se resolverá, cuando fuere pertinente, sobre la relación sustancial aducida y acerca de las indemnizaciones o restituciones a cargo del llamado en garantía.

Parágrafo.

No será necesario notificar personalmente el auto que admite el llamamiento cuando el llamado actúe en el proceso como parte o como representante de alguna de las partes.

Artículo 67. Llamamiento al poseedor o tenedor. El que tenga una cosa a nombre de otro y sea demandado como poseedor de ella, deberá expresarlo así en el término de traslado de la demanda, con la indicación del sitio donde pueda ser notificado el poseedor, so pena de ser 


\section{Ecuador}

\section{El Código de Procedimiento Civil dedica los arts.505 a 507 a las tercerías voluntarias en proceso ordinario ${ }^{167}$ dividiéndolas en}

condenado en el mismo proceso a pagar los perjuicios que su silencio cause al demandante y una multa de quince (15) a treinta (30) salarios mínimos legales mensuales. El juez ordenará notificar al poseedor designado.

Si el citado comparece y reconoce que es poseedor, se tendrá como parte en lugar del demandado, quien quedará fuera del proceso. En este caso, mediante auto que se notificará por estado, el juez ordenará correr traslado de la demanda al poseedor.

Si el citado no comparece o niega su calidad de poseedor, el proceso continuará con el demandado, pero la sentencia surtirá sus efectos respecto de este y del poseedor por él designado.

Lo dispuesto en el presente artículo se aplicará a quien fuere demandado como tenedor de una cosa, si la tenencia radica en otra persona. Cuando en el expediente aparezca la prueba de que el verdadero poseedor o tenedor es persona diferente del demandado o del llamado, el juez de primera instancia, de oficio, ordenará su vinculación. En tal caso, el citado tendrá el mismo término del demandado para contestar la demanda

Artículo 72. Llamamiento de oficio. En cualquiera de las instancias, siempre que el juez advierta colusión, fraude o cualquier otra situación similar en el proceso, ordenará la citación de las personas que puedan resultar perjudicadas, para que hagan valer sus derechos. El citado podrá solicitar pruebas si interviene antes de la audiencia de instrucción y juzgamiento.

${ }^{167}$ Art.505.En la primera instancia del juicio ordinario, antes de sentencia, podrá un tercero alegar derecho preferente o coadyuvante sobre la materia del juicio.

Art.506. Propuesta la tercería, se oirá, por su orden, al demandante y al demandado, y seguirá sustanciándose el juicio, considerando como parte al tercerista; pero no se suspenderá la sustanciación ni los términos, sino desde que se presentó la tercería hasta 
excluyentes y coadyuvantes y los arts 508 a 517 están referidos a las tercerías en juicio ejecutivo (divididas también en excluyentes y coadyuvantes) en base al embargo de bienes. El art.94 regula la citación en caso de evicción ${ }^{\mathbf{1 6 8}}$.

\section{Paraguay}

El Código Procesal Civil de Paraguay, solamente refiere la intervención voluntaria y la excluyente (art.76 a 79).En lo relativo a citaciones obligadas, regula la de evicción (arts.87 a 92) ${ }^{\mathbf{1 6 9}}$.

que fue contestada por el actor y el demandado. El término para la contestación, será el mismo que señala este Código para contestar la demanda ordinaria.

168 Articulo 94. La citación de que trata el Art. 1783 del Código Civil, no puede pedirse sino dentro del término de contestar a la demanda; y pedida, se citará la demanda al vendedor, para que, dentro del término legal, pueda oponerse excepciones. Esta citación se hará con arreglo al inciso primero del artículo que antecede

${ }^{169}$ Artículo 87. Oportunidad. Tanto el actor como el demandado podrán pedir la citación de evicción: el primero, al deducir la demanda; el segundo, dentro del plazo para la contestación de la demanda, según el proceso de que se trate.

La resolución se dictará sin sustanciación previa. y sólo la denegatoria será recurrible sin efecto suspensivo.

Artículo 88. Notificación. Al citado se le notificará en la misma forma y plazo establecido para el demandado. No podrá invocar la improcedencia de la citación, debiendo limitarse a asumir o no la defensa. Si no la ejerciere, su responsabilidad se establecerá en el juicio que corresponda"

Artículo 89. Efectos. La citación solicitada oportunamente suspenderá el curso del proceso durante el plazo que el juez fijare. Será carga del citante activar las diligencias necesarias para el conocimiento del citado. El plazo para oponer excepciones previas y la sustanciación de éstas no quedarán suspendidos". 
Además, las clásicas tercerías de dominio y mejor derecho (arts.80 a 86.)

\section{Perú}

El Código Procesal Civil de Perú, trata en su Sección segunda, Título II, Capítulo VI, al Litisconsorio y en el mismo Título pero Capítulo VII, hace lo propio con la Intervención de terceros, extromisión y sucesión

“Artículo 90. Defensa del citado. Si el citado asumiere la defensa podrá obrar conjunta o separadamente con la parte que solicitó la citación, en el carácter de litisconsorte. Podrá oponer las excepciones previas que no hubiesen sido deducidas por el citante o contestar la demanda. Mediando acuerdo de partes, podrá operarse la sustitución procesal del citante por el citado, cuando aquél fuere el demandado.

Artículo 91. Abstención y tardanza del citado. Si el citado no compareciere o habiendo comparecido se resistiere a asumir la defensa, el juicio proseguirá con quien pidió la citación, salvo los derechos de éste contra aquél.

Durante la sustanciación del juicio, las dos partes podrán proseguir las diligencias para obtener la comparecencia del citado. Si éste se presentare fuera del plazo fijado por el juez, tomará la causa en el estado en que se encuentre.

Articulo 92. Citación de otros causantes. Si el citado pretendiese, a su vez, citar a su causante, podrá hacerlo en los primeros cinco días de haber sido notificado, sin perjuicio de la carga de seguir el proceso por sí. En las mismas condiciones, cada uno de los causantes podrá requerir la citación de su antecesor inmediato. Será admisible el pedido simultáneo de dos o más causantes.

Los causantes citados podrán contestar la demanda dentro del plazo que el juez les fijare, pero tomarán la causa en el estado en que se encuentre. Tendrán derecho a prueba, en segunda instancia, siempre que no hayan podido producirla en primera.

La citación que se hiciere sin la antelación necesaria para que el citado pueda comparecer antes de la sentencia de primera instancia, será ineficaz. 
procesal. La intervención contemplada es la voluntaria, dividida en coadyuvante, litisconsorcial y excluyente. Dentro de ellas señalamos específicamente los arts 102 a 107 por estar referidos a intervenciones resultantes de citación ${ }^{\mathbf{1 7 0}}$ bajo las figuras de denuncia civil, aseguramiento

${ }^{170}$ Art.102. Denuncia civil. El demandado que considere que otra persona, además de él o en su lugar, tiene alguna obligación o responsabilidad en el derecho discutido, debe denunciarlo indicando su nombre y domicilio, a fin de que se le notifique del inicio del proceso.

Art.103. Trámite y efectos de la denuncia, Si el juez considera procedente la denuncia, emplazará al denunciado con las formalidades establecidas para la notificación de la demanda, concediéndole un plazo no mayor de diez días para que intervenga en el proceso, el cual quedará suspendido desde que se admita la denuncia hasta que se emplaza al denunciado.

Una vez emplazado, el denunciado será considerado como litisconsorte del denunciante y tendrá las mismas facultades que éste.

La sentencia resolverá cuando fuera pertinente, sobre la relación sustancial entre el denunciante y el denunciado.

Art.104. Aseguramiento de pretensión futura. La parte que considere tener derecho para exigir de un tercero una indemnización por el daño o perjuicio que pudiere causarle el resultado de un proceso, o derecho a repetir contra dicho tercero lo que debiera pagar en ejecución de sentencia, puede solicitar el emplazamiento del tercero con el objeto de que en el mismo proceso se resuelva además la pretensión que tuviera contra él.

El llamamiento queda sujeto al trámite y efectos previstos en el artículo 103.

Art.105. Llamamiento posesorio. Quien teniendo un bien en nombre de otro, es demandado como poseedor de él, debe expresarlo en la contestación a la demanda, precisando el domicilio del poseedor, bajo apercibimiento de ser condenado en el mismo proceso a pagar una indemnización por los daños y perjuicios que su silencio cause al demandante, además de la multa prevista en el artículo 65. Para el emplazamiento al poseedor designado se seguirá el trámite descrito en el artículo 103". 
de pretensión futura, llamamiento posesorio y llamamiento en caso de fraude o colusión. En realidad, la denuncia civil del art.102 es una figura genérica mentora de un mecanismo judicial destinado a incorporar un tercero al proceso que la letra legal permite al demandado, pero que es extensible al actor cuando fuere demandado reconvencionalmente ${ }^{171}$. La letra legal del art.102 parece tener un amplio campo de aplicación ya que podría servir incluso para que un deudor solidario demandado cite a los otros codeudores solidarios a fin que en la misma sentencia que condene al primero se establezcan los porcentajes que aquéllos le deban ${ }^{172}$.

\section{Uruguay}

Si el citado comparece y reconoce que es el poseedor, reemplazará al demandado, quien quedará afuera del proceso. En este caso, el Juez emplazará con la demanda al poseedor.

Si el citado no comparece, o haciéndolo niega su calidad de poseedor, el proceso continuará con el demandado, pero la sentencia surtirá efecto respecto de éste y del poseedor por él designado.

Lo normado en este artículo es aplicable a quien fue demandado como tenedor de un bien, cuando la tenencia radica en otra persona.

Art.106. Llamamiento en caso de fraude o colusión. Cuando en cualquier etapa del proceso se presuma fraude o colusión entre las partes, el Juez, de oficio, ordenará la citación de las personas que puedan resultar perjudicadas, a fin de que hagan valer sus derechos. Para tal efecto, el Juez puede suspender el proceso por un plazo no mayor de treinta días."

${ }^{171}$ Carrión Lugo Jorge. Tratado de Derecho Procesal Civil, Segunda edición, t.I, pg.323. Editora Jurídica Grijley. Lima. 2004.

${ }^{172}$ Carrión Lugo Jorge.Obra citada, pg.324. 
El primitivo Código de Procedimiento Civil del Uruguay (1878), contiene un título dedicado a "De los terceros opositores en juicio ordinario"; dentro del mismo, el art.520 establece, para la intervención voluntaria, las categorías de tercero opositor coadyuvante y tercero opositor excluyente, respectivamente ${ }^{173}$ Con respecto a la primera, el art.523 delinea los alcances de su actuación en juicio, caracterizándola como subordinada a la parte coadyuvada. No hay una regulación dedicada a la intervención obligada pero el art.522 hace referencia a la posibilidad de intervenir en la causa sin ser citado. ${ }^{174}$

El proyecto de Código Procesal Civil elaborado por Eduardo J.Couture, contempla la citación de evicción (arts.552 y 553),la intervención voluntaria de terceros (art.554)-incluyendo la caracterización del coadyuvante (art.555)- y la de terceros excluyentes(art.555).No figura la intervención obligada, sin embargo, en su art.554, se repite textualmente, el art.522 del código originario que transcribimos.

El Código General del Proceso, inspirado en el Proyecto de Código Modelo para Iberoamérica, establece la que llama "Intervención necesaria por citación", con la posibilidad de oposición por la contraparte; se da en los caso de existencia de garantía por el tercero, o cuando se considerare que la controversia es común o que la sentencia pueda afectar al citado(art.51).También prevé la "Denuncia de terceros" cuando el demandado considere que otra persona, en su lugar o además de él, tiene

\footnotetext{
${ }^{173}$ Art.520. Tercer opositor, es aquél cuya pretensión se opone a la del actor, coadyuvando a la del reo o viceversa, y a veces a la de los dos: en el primer caso, se llamará coadyuvante, y en el segundo excluyente.

${ }^{174}$ Art.522. Los terceros opositores, sean de la clase que fueren, pueden, aun sin ser citados, salir a la causa en cualquier estado que tenga y en cualquier instancia en que se halle."
} 
obligación o responsabilidad con la que responder al actor. El citado no tiene la posibilidad de cuestionar la procedencia del emplazamiento. (art.53).Amén de ello, existe la citación oficiosa o a pedido de parte o del Ministerio Público para dar oportunidad de comparecer al tercero eventual perjudicado, en casos de fraude o colusión ${ }^{175}$.

La doctrina entiende que en el art.51 debe distinguirse por un lado la citación en garantía y por otro los casos de controversia común o efectos comunes de la sentencia. En el primer supuesto, se está ante una acción de garantía que permite la acumulación de pretensiones, lográndose así que el garante quede comprendido en la condena al habilitarse al demandado a dirigir contra él una pretensión de vigencia eventual que permite obviar un

\footnotetext{
${ }^{175}$ Art.51. Intervención necesaria por citación. El demandado, en el plazo para contestar y sin perjuicio de hacerlo, podrá solicitar el emplazamiento de un tercero en garantía o de aquél respecto al cual considera que la controversia es común o a quien la sentencia pueda afectar. El emplazado no podrá objetar la procedencia de su emplazamiento y deberá comparecer; tendrá los mismos derechos deberes y cargas del demandado.
}

Art.52. Oposición al llamamiento de terceros. La contraparte podrá oponerse a la citación de un tercero y el tribunal resolverá la procedencia de la misma por sentencia interlocutoria, que sólo será apelable cuando rechace la intervención.

Art.53. Denuncia de terceros. El demandado, en un proceso en el que considere que otra persona, además o en lugar de él, tiene alguna obligación o responsabilidad en la cuestión controvertida, debe denunciarlo, indicando su nombre y domicilio, a los efectos de que se le noticie del pleito, bajo responsabilidad de los daños y perjuicios que correspondieren por su omisión.

Art.54. Llamamiento de oficio en caso de fraude o colusión. En cualquiera de las instancias, siempre que se presuma fraude o colusión en el proceso, el tribunal de oficio o a petición del Ministerio Público o de parte, ordenará la citación de las personas que puedan ser perjudicadas para que hagan valer sus derechos, pudiéndose, a tal fin, suspender el proceso hasta por cuarenta días. 
juicio ulterior como vía de regreso. En el segundo, no hay pretensión del citante contra el tercero sino que se trata de integrar la litis- sin que ello tenga carácter de necesario- para que participen quienes pudieron ser bien litisconsortes, bien únicos demandados ${ }^{176}$.

\section{Venezuela}

El Código de Procedimiento Civil de Venezuela, cuenta con un Capítulo dedicado a la intervención de terceros compuesto por una disposición general (art.370) y dos secciones dedicadas a la intervención voluntaria (arts 371381 ) y a la forzada (art.382 a 387) respectivamente. En esta última se incluye la citación por saneamiento (arts 385 y 387) ${ }^{177}$.

${ }^{176}$ Código General del Proceso, Tomo 2 pgs 167 a 176 .Director Enrique Véscovi. Ed. Abaco. Montevideo. 1993.

${ }^{177}$ Art.370. Los terceros podrán intervenir o ser llamados a la causa pendiente entre otras personas, en los casos siguientes:

$1^{\circ}$. Cuando el tercero pretenda tener un derecho preferente al del demandante, o concurrir con éste en el derecho alegado, fundándose en el mismo título; o que son suyos los bienes demandados o embargados, o sometidos a secuestro o a una prohibición de enajenar y gravar, o que tiene derecho a ellos.

$2^{\circ}$. Cuando practicado el embargo sobre bienes que sean propiedad de un tercero, éste se opusiere al mismo de acuerdo a lo previsto en el artículo 546.

$3^{\circ}$. Cuando el tercero tenga un interés jurídico actual en sostener las razones de alguna de las partes y pretenda ayudarlas a vencer en el proceso.

$4^{\circ}$. Cuando alguna de las partes pida la intervención el tercero, por ser común a éste la causa pendiente. 
Loreto, tratando la que a diferencia de la intervención voluntaria se denomina intervención forzada, señala su carácter accesorio ,su producción

$5^{\circ}$. Cuando alguna de las partes pretenda un derecho de saneamiento o de garantía respecto del tercero y pida su intervención en causa.

$6^{\circ}$. Para apelar una sentencia definitiva, en los casos permitidos en el art.297.

Art.382.La llamada a la causa de los terceros a que se refieren los ordinales $4^{\circ}$ y $5^{\circ}$ del artículo 370, se hará en la contestación de la demanda y se ordenará su citación en las formas ordinarias, para que comparezcan en el término de la distancia y tres días más.

La llamada de los terceros a la causa no será admitida por el Tribunal si no se acompaña como fundamento de ella la prueba documental.

Art.384. Todas las cuestiones relativas a la intervención serán resueltas por el Juez de la causa en la sentencia definitiva.

Art.385. En los casos de saneamiento, la parte puede pedir ,a su elección, la intervención de su causante inmediato, o la del causante remoto, o la de cualquiera de ellos simultáneamente.

Art.386.Si el citado que comparece pidiere que se cite a otra persona ,se practicará la citación en los mismos términos, y así cuantas ocurran.

Al proponerse la primera cita ,se suspenderá el curso de la causa principal por el término de noventa días, dentro del cual deberán realizarse todas la citas y sus contestaciones. Pero si no se propusiesen nuevas citas, la causa seguirá su curso el día siguiente a la última contestación, aunque dicho término no hubiere vencido, quedando abierto a pruebas el juicio principal y las citas".

Art.387. Lo dispuesto en los artículos anteriores no impedirá que el interesado pueda proponer, si lo prefiere, su demanda principal de saneamiento o garantía contra la persona que deba sanear o garantizar, pero en este caso, la decisión sobre esta demanda, corresponderá al Tribunal donde está pendiente la causa principal, a la cual se acumulará aquella para que una sola sentencia comprenda a todos los interesados.

La acumulación de que trata éste artículo solo podrá realizarse en primera instancia, siempre que, tanto la demanda de saneamiento o garantía, como la principal, se encuentren en estado de sentencia". 
solo a instancia de parte y su finalidad de traer o llamar al proceso a quien tenga con las partes o con una de ellas, una relación sustantiva que muestre “conexidad o comunidad de títulos con las que se debaten en el juicio”"

${ }^{178}$ Loreto Luis. La cita de saneamiento y de garantía (Esquema Magistral de la tercería) en De la tercería en el Derecho Procesal Civil. Doctrina. Legislación. Jurisprudencia. Segunda edición aumentada. ,pg.11. Caracas. 1994 
CAPITULO TERCERO.

\section{LA INTERVENCION OBLIGADA.}

DERECHO ARGENTINO

SECCION PRIMERA

ANTECEDENTES

\section{La doctrina}

No es frecuente encontrar en la doctrina argentina de las primeras décadas del siglo XX material dedicado a los terceros y su participación en juicio; mucho menos a la modalidad de intervención obligada. No habíamos recibido el impulso significado por el pensamiento europeo, fundamentalmente alemán e italiano, que profundiza en aquel fenómeno procesal, de manera que solamente encontraremos estudios relativos a las clásicas tercería de dominio y mejor derecho y la citación de evicción.

Sin embargo y como lo recordaran Mercader y Podetti no solamente el tema había llamado la atención de los prácticos españoles (ver al respecto nuestras citas en el punto 19), sino que lo transmitieron a los prácticos americanos; tenemos así que Manuel Antonio de Castro, tratando el juicio ejecutivo y el embargo y ejecución de bienes, recuerda que los "jurisperitos" dividen a los terceros opositores en tres clases: los codayuvantes del actor y los del demandado respectivos auxiliares de los intereses de dichos sujetos y por último, los excluyentes que vienen a 
sostener el interés propio enfrentándose con actor y demandado. Los coadyuvantes deben tomar el proceso en el estado en el que se encuentre, pero los excluyentes, por el contrario, han de ser admitidos desde el principio $^{179}$.

Mucho más adelante, Rodríguez, introduce en el comentario relativo a las tercerías de dominio y mejor derecho del Código de Procedimientos Civil y Comercial de la Capital, una referencia que merece consignarse: "La antigua jurisprudencia española admitía dos clases de tercerías: la excluyente, aquella en que el tercer opositor alega en su favor un derecho propio que opone al actor y demandado, y la coadyuvante, cuando sostiene las pretensiones de alguno de aquéllos. Esta división, dice con sobrada razón Reus, debe desaparecer. Cuando en un litigio se presenta un tercero sosteniendo las mismas pretensiones que cualquiera de los otros dos, con arreglo a los principios que la ley presente establece, lo que procede es que se una á aquel á quien trata de ayudar y que, unidos, litiguen bajo una sola dirección. Entonces no hay, no puede haber tercería. Habrá pleito de uno contra dos y no otra cosa. Para que la tercería exista son condiciones sine qua non que el tercero se presente en juicio y promovido y haga oposición a lo declarado por los otros dos, ó deduzca reclamaciones distintas de los que los otros dos alegan, ó sostenga que le asiste un derecho preferente al de cualquiera de ellos" ${ }^{\text {,180. }}$

\footnotetext{
179 Castro de Manuel Antonio. Prontuario de practica forense, pgs. 246 y 247. Segunda edición. Imprenta Nacional Argentina. Bueno Aires, 1863 )

${ }^{180}$ Rodríguez Alberto M. Comentarios al Código de Procedimientos en materia Civil y Comercial de la Capital de la República Argentina, Segunda edición. Tomo Segundo, pgs 316 y 317.S.A.I.G. Barcelona Seix \& Barral Hermanos. Barcelona.1914
} 
Tomás Jofré que es considerado como el introductor de Chiovenda en América del Sur,en la edición que poseemos, encara el tratamiento de tercerías de dominio y mejor derecho, vinculándolas con la sustitución y el liticonsorcio. Se refiere a la intervención obligada de terceros con ejemplificaciones (acreedores intervinientes en causa de sus deudores, fiador citado en causa entre locador y locatario, rescisión de un contrato hipotecario con la presencia de acreedor, locador y locatario) y formula que "como principio general podemos afirmar que siempre que la sentencia pueda oponerse a personas que no han sido parte en el juicio deben éstos ser llamados al mismo para que intervengan" ${ }^{\mathbf{1 8 1}}$.

Alsina publica en 1940 su trabajo "Intervención de terceros en la relación procesal” ${ }^{\mathbf{1 8 2}}$.En él, parte de la existencia de una intervención voluntaria que puede ser adhesiva o excluyente, y otra obligada constitutiva de la litisdenuntiatio comprensiva de la evicción; explicita que el tercero puede hacer valer su interés en los procesos de conocimiento interviniendo para asumir carácter de sujeto de la relación procesal y en los ejecutivos operando como terceros no afectados a la relación debatida ni por la sentencia que se dicte. Posteriormente se ocupa del tema en su Tratado Teórico Práctico de Derecho Procesal Civil y Comercial, primera edición 1941 y luego en ediciones posteriores. Así, lleva adelante el estudio del litisconsorcio, la substitución procesal, y la intervención de terceros, que siguiendo la orientación de la codificación, la doctrina, y la jurisprudencia europea, divide en voluntaria y obligada. Con respecto a esta

\footnotetext{
181 Jofré Tomás, Manual de Procedimiento (Civil y Penal) t.III, Segunda edición; pgs 104 y 105 .Valerio Abeledo. 1920. Buenos Aires.

${ }^{182}$ Alsina Hugo. Intervención de terceros en la relación procesal.J.A.t.71-Sec.Doctrina, pg.4.
} 
última dice que en principio corresponde a los casos en los que está permitida la acumulación subjetiva impropia pasiva de acciones como forma inicial de proceso. Relata que como casos especiales de tal modalidad de intervención, se encuentra la litisdenunciatio cuando la parte en caso de ser vencida, podría tener una acción contra el tercero -ejemplos, la evicción del art.2108 Cód.Civil,los de los arts 1123,1125,1133 del mismo código entre otros-; la laudatio o nominatio auctoris cuando el poseedor demandado denuncia el nombre de aquel por quien posee; el llamamiento del tercero pretendiente cuando el demandado por la entrega de una cosa o el pago de una deuda llama al tercero que también pretende ser propietario o acreedor (art.757 inc. $4^{\circ}$ Cód.Civil),y la llamada en garantía cuando el llamante se encuentra en el pleito por una obligación del llamado (fiador respecto del deudor). ${ }^{\mathbf{1 8 3}}$.

En otro trabajo, observa que generalmente se considera que el tercero que interviene litisconsorcialmente para defender un interés, "solo coadyuva con una de las partes, y en consecuencia no puede aducir razones ni proponer pruebas que sean contrarias a la parte a la cual adhiriere. Sin embargo entiende que otro debe ser el punto de partida: si la intervención es voluntaria, como en el caso del acreedor que interviene para prevenir la negligencia o el dolo de su deudor codemandado, no se puede considerar subordinado y debe poder actuar en forma autónoma, es decir aun contrariando las afirmaciones y la prueba de aquél, si la intervención es obligada y el tercero se sustituye la parte principal, se aplicarán los

\footnotetext{
${ }^{183}$ Alsina Hugo. Tratado Teórico Práctico de Derecho Procesal Civil y Comercial, Segunda edición T.I,pgs 563 a 565.Ediar. Buenos Aires. 1956
} 
principios de la substitución procesal; en caso contrario, regirán las reglas del litisconsorcio" ${ }^{, 184}$.

Mercader nos recuerda antiguas aunque tenues raíces del problema tercerístico entre los prácticos españoles y aun hispanos sudamericanos, así como una enjundiosa mención de la nueva literatura jurídica italiana, no obstante que critica duramente la idea de admitir en los procesos de conocimiento cualquier forma de intervención de terceros.

Expresa así que el acceso del tercero a un pleito ajeno constituye un fenómeno de naturaleza procesal absolutamente distinto del que se produce en la etapa de ejecución, "Porque, mientras en estas últimas hipótesis de lo único que se trata es de una pretensión de dominio, o de mejor derecho a bienes embargados y en trance de venta, o a su producido, en las primeras lo que el extraño pretende, en cambio, es intervenir en el desarrollo del proceso para gestionar una sentencia que le beneficie, o que -cuando menos- no le perjudique. Esta clase de acaecimientos, a mi juicio, carece de legitimación procesal posible, por estar en contra de todos y de cada uno de los presupuestos procesales" ${ }^{185}$. Añade que las intervenciones voluntarias, o forzadas, principales o adhesivas son insostenibles dentro de los conceptos procesales ortodoxos, "Porque mientras el proceso no deje de ser una contienda necesariamente bilateral no ha de encontrarse el medio de justificar la causa en cuya virtud haya de concedérseles a los terceros intervención alguna"186 . Se explica por qué en la ejecución forzada puede admitirse a terceros, ya que la venta judicial de bienes, máxime si son

\footnotetext{
${ }^{184}$ Alsina Hugo "Unificación de la legislación acerca de la intervención de terceros en la relación procesal (J.A.1957-IV-50 Sec. Doctrina)

${ }^{185}$ Mercader Amilcar. El tercero en el proceso.pg 73.Abeledo Perrot.Buenos Aires.1960

${ }^{186}$ Mercader Amilcar. Obra citada, pg.74
} 
muebles en la que la posesión vale título, puede crear situaciones, irreparables para quienes aleguen sobre los bienes derechos de dominio o privilegios especiales. En tal caso es conveniente acumular a las actuaciones ejecutivas, las pretensiones planteadas por los terceros, racionalizando así la actuación judicial, evitando escándalos jurídicos derivados de sentencias contradictorias. Señala que en realidad no hay allí extraños que interfieran la relación procesal entre ejecutados y ejecutantes sino sujetos que plantean sus pretensiones para ser acumuladas en lo actuado por tratarse de los derechos propios no confundibles con la de los litigantes originarios. Con respecto a los demás casos de tercerías, dice que "cuando se produce la cita de evicción y saneamiento, lo que en definitiva se provoca no es nada más que un caso de substitución procesal derivado de las garantías debidas por los enajenantes a los compradores" ${ }^{187}$, que como accidentes del proceso no juegan sino como excepciones dilatorias y esencialmente defensas temporarias, aun cuando se admita la actuación litisconsorcial del citante. En los casos de oposición tampoco pueda hablarse estrictamente de tercero, sino de formas cumulativas pues "cada uno de los opositores tiene que fundar la oposición en su carácter de titular de una acción autónoma, distinta y extraña a la que ya están deducidas en el proceso" ${ }^{188}$.

En su "Tratado" de Podetti que ya citamos, el autor defiende la denominación que utiliza , "Tercerías" de amplio significado pues incluye en ella las distintas formas de intervención y de estructuras litisconsorciales, así como las clásicas tercerías de dominio y de mejor derecho o de preferencia.

\footnotetext{
${ }^{187}$ Mercader Amilcar. Obra citada,pg. 84

${ }^{188}$ Mercader Amilcar. Obra citada,pg.85
} 
Elabora una compleja clasificación sobre la base del concepto de interés en la actuación procesal: partiendo de la existencia de un interés propio y otro ajeno. El primero puede ser originario y no originario. El originario puede ser directo o indirecto. El directo puede ser excluyente (incluye tercerías de condominio o de posesión, de mejor derecho, intervención de hipotecarios, intervención del sublocatario, citación del legitimado pasivo, llamado al pretendiente) y no excluyente a saber: a) con legitimación autónoma -litisconsorcios voluntarios propios e impropios- ;b) con legitimación heterónoma-litisconsorcios necesarios propios $\mathrm{y}$ anómalos). El interés originario indirecto se genera en la sustitución procesal, provocada (citación de evicción, fianza, seguro de responsabilidad) o no provocada (acción oblicua). El interés no originario se da en la sucesión procesal universal y singular. El interés ajeno en la legitimación familiar o por categorías y en la legitimación pública ${ }^{189}$ Trata de las tercerías de dominio y mejor derecho en el proceso ejecutivo( Capítulo IV) y en el Capítulo V. de las "Tercerías excluyentes en otras clases de procesos" Recuerda entonces las enseñanzas de los prácticos españoles (Conde de la Cañada, Elizondo) y americanos (Hevia Bolaños y más adelante en Argentina, Manuel Antonio de Castro) acerca de la diferenciación entre terceros coadyuvantes y terceros excluyentes. Señala a la par, su discrepancia con las ideas de Mercader ${ }^{190}$. En su obra actualizada encontramos una referencia a la tercería coactiva condensada en el CPCCN en su art.96 señalándose que puede ser provocada por pedido de uno de los sujetos (evicción, llamamiento al verdadero poseedor) o por orden del juez (citación del hipotecario, integración de la litis), pero, de ahí en más, el

\footnotetext{
${ }^{189}$ Podetti J.Ramiro.Obra citada, pg.50.

${ }^{190}$ Podetti J.Ramiro.Obra citada,pg. 57.
} 
autor se dedica a enunciar los casos particulares a tratar más adelante ${ }^{191}$. Se pasa así al Capítulo VII(“Otras formas de tercería en interés propio originario, directo y excluyente.") lugar en el que se consideran sucesivamente las tercerías provocadas por la ejecución de un inmueble gravado por hipoteca; la intervención del acreedor hipotecario en la ejecución donde se va a subastar su garantía (ver al respecto punto 57b); la figura del tercer poseedor ( ver igualmente punto 57b); la intervención del sub-inquilino en el juicio de desalojo entre locador y locatario (ver al respecto punto 58). El maestro mendocino entra en el campo específico de la intervención obligada en los puntos titulados "La denuncia de litis. Intervención del "verus posesor" y "La denuncia de litis. Llamado al pretendiente."

En los Capítulos VIII y IX, considera, respectivamente, los litisconsorcios voluntario y necesario y en el $\mathrm{X}$ aborda el fenómeno de la sustitución procesal a través de la acción oblicua del art.1196 Cód.Civil. En el Capítulo XI, titulado "Citación de evicción" nos dice que el llamado en garantía o denuncia de litis, abarca cuatro casos distintos: así, la evicción, el litisconsorcio (voluntario y necesario), la laudatio o nominatio auctoris y por último, el llamamiento al tercero pretendiente. Con respecto a la evicción sostiene que incluye los supuestos de transmisión contractual de bienes por un lado (art.2108 Cód.Civil), pero también, por otro, de "obligaciones derivadas de numerosos hechos de relevancia jurídica" entre los que cita las situaciones referidas por los arts.1123,113 y 1109,1124 del Código Civil y 525 y 1262 del Cód. de Comercio .El autor referencia al respecto, las disposiciones de los arts. 105 al12( 110 a 112 del CPCCN en su numeración actual). El libro se completa con los Capítulos XII

${ }^{191}$ Podetti J.Ramiro. Obra citada, pgs. 199 y 200 
("Interventor del fiador" dedicado al régimen resultante del contrato de fianza),XII (Intervención del asegurador),XIV,(“Sucesión procesal”) y XV (“Legitimación familiar y pública”).

Sin perjuicio de autores de primera línea que iremos citando en el curso de nuestro trabajo (entre otros, Adolfo Alvarado Velloso, Atilio C. González, Hernán J.Martínez, Augusto Mario Morello, Lino E.Palacio, Roland Arazi) que se ocuparon de la intervención obligada dentro de sus obras y/o en trabajos especiales, por tratarse de una obra específica, para finalizar esta reseña, nos detendremos en Kenny y en su libro "La intervención obligada de terceros en el proceso civil". Analizando el concepto de controversia común, el autor recuerda que en general la doctrina europea entiende que se configura ante la existencia de una relación jurídica entre una de las partes y un tercero que resulte conexa con los elementos objetivos de la primitiva pretensión procesal. Recuerda que al respecto, los autores se dividen, pues unos entienden que deben de estar presentes los dos elementos objetivos y otros sostienen que basta con uno. A su juicio, el concepto referido no se circunscribe solamente al ámbito de las relaciones jurídicas sino que también comprende al de las situaciones (por ejemplo las que generan los derechos reales o los vínculos de familia). Además, considera que la comunidad solamente exige la presencia de causa pero no del objeto de la pretensión pues ése no es sino un efecto resultante de aquélla y por ende constitutivo de una relación o situación jurídica indirecta o de segundo grado con respecto a la cuestión común. Estima entonces que" habrá controversia común cuando se entienda que la eventual decisión judicial que resuelva sobre la relación o situación jurídica planteada en el proceso y que constituya la causa de la pretensión, pueda de alguna manera afectar, rozar, alterar, gravitar o comprometer la relación o 
situación jurídica extracontenciosa existente entre una de las partes y el tercero" ${ }^{\prime 192}$.

Sostiene que al establecer el art. 96(94) CPCCN que la citación genera la extensión de la cosa juzgada al tercero, se impone, en homenaje al derecho constitucional de defensa concederle condición de parte, pero, para que pueda darse esa virtud de la sentencia, es indispensable que se haya planteado una pretensión contra ese tercero, condición que entiende deriva del art.164(163) inc.6 CPCCN en su numeración actual. Precisamente y para alcanzarla, adhiere-si bien con críticas- a la teoría de Calamandrei y en consecuencia sostiene "como principio general, que el pedido de citación del tercero, efectuado por una de las partes originarias y con el objeto de que aquél intervenga obligadamente en el proceso a fin de que la sentencia lo alcance, importará para el citante la formulación de una pretensión de mera declaración de certeza (positiva o negativa) de derechos emanados de la relación o situación jurídica externa habida entre una de las partes y el tercero, y que está dirigida ese limitado efecto contra este último ${ }^{193}$. Nos detenemos aquí en esta reseña.

\section{La jurisprudencia nacional}

Ante la ausencia de una regulación específica de la intervención de terceros en el CPrCC Capital, los fallos de los tribunales argentinos fueron

\footnotetext{
${ }^{192}$ Kenny Héctor Eduardo. La intervención obligada de terceros en el proceso civil, pg 33. Depalma. Buenos Aires. 1983

193 Kenny Héctor Eduardo Obra citada, pg.36.
} 
cubriendo ese aspecto. Es claro que en esa tarea, deben separarse los casos en los que trató de salvar el derecho de defensa de quienes debieron ser legitimados pasivos ${ }^{194} \mathrm{de}$ los que hacen a verdaderos terceros y en los que se los admitió como ingresantes voluntarios o coactivos. En este último caso, corresponde citar la rica jurisprudencia de la Corte Suprema en materia de evicción que la fue diseñando antes que apareciera regulada por el $\mathrm{CPCCN}^{195}$ Igualmente los criterios de los distintos tribunales que pretorianamente fueron admitiendo la intervención voluntaria, pero de especial interés para el estudio que encaramos, los que aceptaron citar coactivamente a los litisconsortes calificados para el caso de preverse acciones regresivas ${ }^{196} \sin$ perjuicio de los supuestos en los cuales se dispuso la citación oficiosa para una mejor provisión del juicio ${ }^{197}$

\section{Proyectos de codificación nacional}

\footnotetext{
${ }^{194}$ Nos referimos a los sujetos que siendo propietarios, inquilinos o poseedores fueran omitidos en juicios que les hicieran perder sus derechos y a los que se les abrió la posibilidad de utilizar el recurso extraordinario del art.14 de la ley 48 (CS JA tomo 2,pg.864; t.4,pg.294; t.32 pg.919 entre otros)

${ }^{195}$ Por ejemplo, Santillán de Briceño c/Empresa de Ferrocarril Sunchales del 6/9/1890, Fallos 43:227; Hidalgo Rodolfo c/Gobierno Nacional 28/7/37,JA t.59,pg.38; Milberg Juan c/Pcia de Santa Fé 14/5/43 LL 30 pg.777.

196 Cam.Nac.Civ.Sala A, LL 107-979 (8112 -S); Cam.Nac.Comercial LL 121,fallo 13.308-S;id ED t.13-fallo 7122.

${ }^{197}$ Por ejemplo, en el caso de un litigio referido a la disposición del cadáver del causante ,llamar al hijo que no participaban del proceso-CN.Civ.Sala D,16/11/51 M.,J.M.c/B.R,LL 65-171;Cam.Apelaciones Mar del Plata, Peralta Ramos de Aráoz c/Schicenca de Ferraro,LL 54-394 con nota de Alex Bremberg "Intervención coactiva de terceros en el proceso".
} 
En 1885, ( es decir a poco de ser adoptado por el Estado Nacional, el Código de Procedimientos Civil y Comercial elaborado para la Provincia de Buenos Aires por el Doctor José Domínguez sobre la base de las leyes de enjuiciamiento españolas), los doctores Amancio Alcorta y Estanislao S.Zeballos presentaron en la Cámara de Diputados que integraban como legisladores, un Proyecto de Código de Procedimientos en Materia Civil para los tribunales nacionales y de la capital, con un notable desarrollo en los temas litisconsorcios e intervención de terceros. Al primero se lo regula en los arts. 308 a 312; la intervención voluntaria de terceros- a la que se dividió en coadyuvante y excluyente-, es tratada en los arts. 315 a 320: luego, de las tercerías en juicios ejecutivos se ocupan los arts. 321 a 341; en una sub división especifica se considera la citación a juicio de los terceros garantes (arts. 342 a 351$).{ }^{\mathbf{1 9 8}}$.

\footnotetext{
${ }^{198}$ Art.342 .Cuando alguno de los litigantes, para el caso en que la prosecución del proceso le fuera desfavorable, creyera poder deducir una demanda por garantía o indemnización contra un tercero, o cuando pudiera temer reclamaciones de un tercero, ese litigante podrá notificar judicialmente el proceso al tercero, a fin de que tome conocimiento del asunto y salga en su defensa, si así lo creyere conveniente.
}

Art.343. La citación puede tener por objeto una garantía formal o una garantía simple.

Se llamará garantía formal á aquella que todo concesionario de un derecho real sobre un inmueble ejercite en caso de evicción o de molestias en el goce del derecho cedido o de otros modo tenido de su parte.

Se llamará simple a aquella que se deriva de una obligación.

Art.344. Todo aquél que quiera citar a un tercero en garantía deberá hacerlo en tiempo oportuno.

Se considera tiempo oportuno, si es el demandante el que reclama la citación, al entablar la demanda; y si fuera el demandado, antes de contestarla.

Art.345 Al efecto de la citación impone el uso de la cédula. 
Art.346.El tercero citado podrá a su vez citar a otras personas, y estas citaciones se harán inmediatamente y sin perjuicio de la prosecución del juicio.

Art.347. Cuando se hubiera deducido declinatoria de jurisdicción, el término para la citación empezará a correr una vez que sea resuelta la cuestión de competencia.

Art.348. La citación en garantía no suspende el curso de la causa principal, si no es propuesta y practicada con arreglo a los artículos precedentes.

Art.349. Si la citación ha tenido por objeto una garantía simple, y el tercero compareciera tomar la intervención que le corresponde, su situación respecto a los litisconsortes se regirá por las de las tercerías coadyuvante en el juicio ordinario.

Si el citado rehúsa comparecer o no comparece, el proceso seguirá su curso entre los litigantes, haciendo cosa juzgada respecto de aquella sentencia en que recayere.

Art.350. No obstante lo dispuesto en el inc $2^{\circ}$ del artículo anterior, el tercero podrá comparecer en cualquier estado del juicio y tomar intervención en el estado en que se encuentre, pero para los efectos que dicha intervención ha debido producir, se considerará que ella ha empezado desde que se hizo posible por la notificación del proceso al tercero.

Art.351. Cuando la citación tenga por objeto una garantía formal y el tercero comparece, el litigante que pide la citación, puede reclamar su separación del juicio; pero obtenida ésta, podrá sin embargo asistir al seguimiento de la causa para la conservación y vigilancia de sus derechos. El citado podrá oponerse a la separación solicitada cuando el que cita pudiera estar obligado por actos que personalmente le correspondieran.

Art.352.La asistencia o intervención que acuerda el inciso $1^{\circ}$ del artículo anterior, se reduce a que se notifiquen los autos interlocutorios y las sentencias definitivas, y a interponer los recursos legales que omite el tercero con quien se sigue el juicio.

Art.353.Si el citado no comparece o rehúsa hacerlo en los casos del artículo anterior se continuará la causa sin su presencia con los efectos establecidos en el inciso $2^{\circ}$, art.349 y el art.350 para la garantía simple.

Art.354. Los efectos de la sentencia pronunciada en los casos que dieran lugar la citación serán:

$1^{\circ}$ En los casos de garantía simple: promovida contra el garante es ejecutiva contra él y contra el garantido, tanto en lo principal como en los daños e intereses y costas. 
En 1910 una comisión formada por los Doctores Pedro Agote y Ramón Méndez presentó al ministro de Justicia Rómulo Neón, un proyecto de código de procedimientos civiles en el que se trataban las tercerías en juicio ejecutivo aplicable a las que se dedujesen en cualquier situación en la que se embargaren bienes (arts.394 a 401) ${ }^{199} \mathrm{El}$ proyecto fue presentado en la Cámara de Diputados sin ninguna modificación por el diputado Manuel Pinto en mayo de 1925, pero no se trató.

En 1926 Mariano G.Calvento presentó un "Proyecto de Código de Procedimientos Civil y Comercial para la Capital y Territorios Nacionales". En su título Segundo (Juicio ordinario)el art. 113 se ocupa "De la citación de evicción"

$2^{\circ}$ En los casos de garantía formal: promovida contra el garante es ejecutada también contra el garantido en lo principal; pero en cuanto a los gastos y daños e intereses solo surte efecto contra el garante, no siendo contra el garantido sino en los que le sean imputables, á no ser que el garante fuese insolvente.

${ }^{199}$ Proyecto de Código de Procedimientos Civiles .Tipografía de la Prisión Nacional. Buenos Aires. 1910.

${ }^{200}$ Tanto el actor como el demandado podrán solicitar la citación de evicción, el primero al entablar la demanda y el segundo dentro del término señalado para poner excepciones por el art.108.

La citación se hará en la forma establecida en el Título I, Capítulo V fijándose al citado el término de quince días para que comparezca, suspendiéndose entre tanto el procedimiento.

Si este usara el derecho de llamar a otro, deberá hacerlo dentro de los nueve días de la citación.

Vencidos los quince días que este artículo acuerda para comparecer al citado de evicción se entenderá el procedimiento con él si comparece o con el demandado si no lo hace o impugnare de cualquier modo la citación. El término para oponer excepciones o contestar la demanda se contará desde el vencimiento de los quince días. 
incidentes, y en él se consideran las "tercerías en general" con referencia a las intervenciones voluntarias a las que se divide en coadyuvantes del derecho de alguna de las partes (art.286) -con sentencia que le obliga como al principal luego de su participación- y excluyentes (art.287) con su correspondiente tramitación. El art.294 introduce la figura del "opositor coadyuvante" ${ }^{, 201}$.

El Proyecto de Código de Procedimiento Civil elaborado por Tomás Jofré en 1926, preve la excepción dilatoria de evicción con posibilidad para el garante citado de llamar a otros enajenantes y suspensión del proceso mientras se resolvía (arts.56,57 y 58).

El proyecto de Código Procesal Civil elaborado por Raymundo L.Fernández (presentado al Poder Ejecutivo en 1959) contiene como normas comunes, a las modalidades de intervención que establecía el art.73 .II (intervenciones voluntarias o forzadas), proclama que el coadyuvante actuará como litisconsorte del litigante a quien ayuda y posee sus mismas facultades procesales; con la conformidad de la contraria puede sustituir al citante, pero en ese caso, éste deber asumir condición de coadyuvante quedando obligado a absolver posiciones y reconocer firmas. Puede ser excluido del litigio con la conformidad expresa

Las cuestiones que se susciten entre el citante y el citado se sustanciarán en pieza separada.

Podrán actuar conjuntamente el demandado y el citado de evicción, pero deberán y hacerlo bajo una sola representación.

Si el actor se opusiese a la citación el incidente se tramitará y resolverá en la forma establecida para las excepciones.

${ }^{201}$ Art.294.El opositor coadyuvante tiene derecho a intervenir en el avalúo y venta de los bienes sobre, los que recae la tercería. 
de la contraparte (art.73 II). Se consagra el efecto extensivo de la cosa juzgada (art.73 .III).

En la intervención voluntaria, se considera la existencia de una excluyente así como de otra coadyuvante, entendiéndose por ésta la que genera el tercero que pase a defender un interés propio originario, o bien un interés ajeno que por convención o disposición legal pueda incidir en el propio. El objetivo de tal intervención es el de coadyuvar con uno de los litigantes o sustituirlo (art.74). La intervención forzada, referida a los casos en los que el litigante tiene derecho a pedir la defensa o garantía de terceros respecto del objeto materia de la litis, aparece dividida en tercería coadyuvante y tercería parcialmente excluyente; la citación se puede pedir a efectos de coadyuvación con el convocante, o a fines de su sustitución por el tercero.(art.79).La incomparecencia del tercero no le trae ninguna sanción procesal "sin perjuicio de los derechos que por ley o convención tenga el citante, los cuales no pueden discutirse en el proceso en que se pidió la citación" (art.84 segunda parte). Se regula también la tercería de dominio y de mejor derecho en los procesos de ejecución (art.78) ${ }^{\mathbf{2 0 2}}$.

202 ).”Capítulo V. Intervención de terceros en el proceso.

Art.72. Preceptos que la rigen .La intervención voluntaria o forzada de terceros en el proceso se rige por las normas generales del presente capitulo, las del interés requerido para la acción (artículo 59) y las específicas que este código establece en otras disposiciones, incluso, en cuanto sea pertinente, las que corresponden a los proceso con pluralidad de litigantes (arts 64 a 71) y la sucesión a título singular de los derechos en litigio (art.30).

Art.73.Posición procesal del tercerista. I. En la tercería excluyente, actor, demandado y tercerista son considero contrarios ente sí, pueden ponerse posiciones recíprocamente y ejercer cada uno de ellos todas las facultades procesales para la sustanciación y fallo del litigio. Los traslados de las peticiones de cada uno, cuando corresponda, se correrán a los otros dos. 
II. El tercerista coadyuvante actúa como litisconsorte del litigante a quien ayuda y posee sus mismas facultades procesales .Con la conformidad de la contraparte puede sustituirlo, en cuyo caso, éste asumirá ,a su vez, el rol de coadyuvante, pero obligado a absolver posiciones y reconocer firmas; su exclusión del litigio requiere la conformidad expresa de la contraria.

III. Cualquiera sea la forma de la intervención de terceros, la sentencia tiene efectos de cosa juzgada en contra o a favor de los mismos

\section{Sección III}

"Art.79. Terceria coadyuvante y tercería parcialmente excluyente" Los litigantes en general, cuando tienen derecho de pedir la defensa o garantía de terceros respecto del objeto materia de la citación(citación de evicción y otros supuestos),pueden solicitar su citación a efecto de que comparezcan en el proceso para sustituirlos o para coadyuvar con ellos.

Puede pedirse a la vez la citación de dos o más causantes en la cosa litigiosa.

Art.80. Citación del tercero. I. La citación se decretará sin trámite alguno y sin que puedan objetarla los demás litigantes.

II. La citación debe pedirse:

a) Por el actor, antes o juntamente con la demanda o cinco días después de agregada la contestación, si de ella surge la necesidad de la citación.

b) Por el demandado o el reconvenido, dentro de los seis días del emplazamiento para contestar la demanda o la reconvención, y si el emplazamiento es menor, antes o en el acto de contestar.

El tercero citado puede a su vez citar a otro tercero, en los plazos indicados en el apartado anterior, párrafo $b$.

III. La resolución del tribunal denegando la citación, sólo es recurrible por apelación sin efecto suspensivo, si emana de tribunal de primer instancia.

Art.81. Suspensión del procedimiento. Si de la demanda con la que se instruye la petición surge "prima facie" el derecho invocado por el citante, se suspenderá el procedimiento mientras se notifica la citación y vencen los plazos. En caso contrario, se dispondrá la citación pero no se suspenderá el procedimiento. 
En el Proyecto del Poder Ejecutivo de Código de Código Procesal Civil de 1949 conocido como proyecto Podetti, se preve un Capítulo (arts 99 y 100) de aplicación general, para luego en sendos capítulos regular las tercerías excluyentes (arts 101 a 104)y coadyuvantes (arts.105 a 107).En aquel primer espacio, se estable que la intervención de terceros en un proceso pendiente, puede ser espontánea o por citación a pedido de los litigantes o de oficio. La sentencia tiene efecto de cosa juzgada en todo

Art.82.Plazo para notificar y trámite de la tercería. I. El tribunal al ordenar la citación fijará plazo para que la misma se efectúe.

II. El citante deberá urgir para que la citación se verifique y si no tiene lugar en el plazo fijado, decaerá automáticamente el derecho al emplazamiento, prosiguiendo la causa según su estado y reanudándose el plazo que corría para el citante.

III. Asimismo, el tribunal, teniendo en consideración la naturaleza e importancia del principal, dispondrá si la intervención del tercero debe o no sustanciarse por cuerda separada.

Art.83.Plazo para comparecer. El tercero debe comparecer:

a) Si la citación la pide por el actor, dentro de los diez días de la notificación, pudiendo modificar o ampliar la demanda si ha sido deducida por el citante o de lo contrario, deducirla en el mismo plazo.

b) Si se pide por el demandado, y según se oponga excepciones previas, o conteste la demanda, en los plazos legales en que lo podía hacer el citante.

c) Si se pide por uno de los citados, en el plazo que corresponda al primer citado, conforme a los incisos precedentes.

Art.84. Efectos de la incomparecencia. Transcurrido el plazo legal sin que el citado comparezca en el proceso, automáticamente proseguirá su trámite y seguirá corriendo el que gozaba el citante, el cual puede, empero, seguir haciendo las gestiones necesarias para el comparendo del citado; si éste comparece, tomará la causa en el estado en que la encuentre.

La incomparecencia no trae aparejada ninguna sanción procesal contra el citado, sin perjuicio de los derechos que por ley o por convención tenga el citante, los cuales no pueden discutirse en el proceso en que se pidió la citación." 
caso (art.99). Sea para hacer valer un derecho total o parcialmente excluyente, o para coadyuvar resulta necesario invocar un interés jurídicamente protegido (art.100). En cuanto a la tercería coadyuvante incluye a quienes tuvieran un interés propio originario o a los que por convención o disposición legal tuvieran que defender un derecho ajeno que pudiera incidir en el suyo. El tercero en alguna de esas condiciones, puede intervenir como coadyuvante o sustituto (art.105). Se asigna al tercero coadyuvante citado a pedido de los litigantes originarios, los mismos derechos que los excluyentes por remisión al art.103, es decir el ejercicio de todas las facultades procesales desde la demanda o responde según el caso (art.100). El tercero coadyuvante opera como colitigante del coadyuvado y hasta puede sustituirlo (art.107). El art.103 señala que los terceros excluyentes citados a comparecer de oficio o a pedido de parte, tienen derecho al ejercicio de todas las facultades procesales, desde la demanda o responde según sea su situación ${ }^{203}$.

\footnotetext{
203 “Título V. De las tercerías. Capítulo I. Normas comunes. Art.99. La intervención de terceros en un proceso pendiente, sea espontánea o por citación a pedido de litigantes o de oficio, se ajustará a las normas establecidas en este Código, con las modificaciones que contiene este capítulo.
}

En cuanto sea pertinente, se aplicarán también las reglas de este título a la acumulación subjetiva (arts.41 y 42), a la sustitución y a la sucesión procesales

En todo caso, la sentencia tendrá efectos de cosa juzgada en contra o a favor del tercero interviniente.

Art.100. Para intervenir en un proceso pendiente, con objeto de hacer valer un derecho total o parcialmente excluyente, incluido en la litis con relación a todos los litigantes originarios o a alguno de ellos, o para coadyuvar con los mismos, es necesario invocar un interés jurídicamente protegido, conforme al art.39. 
Una comisión integrada por los Dres Carlos J.Colombo, Julio Cueto Rúa, Raul Etcheverry y Héctor Umaschi, presentó al Ministerio de Justicia de la Nación en 1993 un proyecto de Código Procesal Civil ,Comercial y Laboral en el que sus arts 97 y 98 repiten los textos de los arts.94 y 95 COCAN en sus redacciones vigentes para entonces. El art.99, luego de establecer el alcance de la cosa juzgada sobre el tercero citado, dispone que también será ejecutable a su respecto si se dieran una serie de condiciones que se determinan ${ }^{204}$. El proyecto incluye en su art.100, una citación

Art.106.Los terceros coadyuvantes citados a comparecer a pedido de litigantes originarios, tendrán los mismos derechos de los excluyentes, aplicándose lo dispuesto por los dos primeros apartados del art.103.

Art.107.El tercerista coadyuvante actuará como colitigante de aquél con quien coadyuva y tendrá sus mismas facultades procesales.

Podrá sustituir a quien pidió su citación, manteniéndose la posición de litigante, coadyuvando con su substituto. La exclusión de este último del litigio, requiere la conformidad expresa de la contraria".

Art.103.Los terceros excluyentes, citados a comparecer por pedido de litigantes originarios o de oficio, tienen derecho al ejercicio de todas las facultades procesales, desde la demanda o responde según su situación.

Cuando la citación haya sido pedida por uno de los litigantes originarios, se procederá como lo dispone el art.102.

Siendo la citación de oficio para integrar la litis, se suspenderá el procedimiento hasta que venza el plazo de aquélla y se sustanciará en el mismo expediente.

${ }^{204}$ Art.99. Alcance de la sentencia. En todos los supuestos, la sentencia dictada después de la intervención del tercero, o de su citación, en su caso, lo afectará como a los litigantes principales. Será ejecutable a su respecto:

1) Si el actor hubiese pedido la citación y condena del tercero.

2) Si al sustanciarse el pedido de intervención el actor hubiese adherido y solicitado la condena. 
oficiosa en caso de proceso fraudulento, similar a la contenida en el art.64 del Código Procesal Civil Modelo para Iberoamérica recogido por el art.54 CGP Uruguay.

\section{Antecedentes provinciales}

Sin tratar de establecer cuál de los códigos que consideraremos sirvió de fuente a los demás, elegimos para glosarlo al Código de Procedimiento Civil y Comercial de Córdoba,(ley 1419 de 1896).Tal ordenamiento, regula la "citación por evicción y saneamiento" (arts.1029 a 1037) y las tercería en juicio ejecutivo -dominio y mejor derecho-(arts1044 a 1052). También dedica una sección a las tercería en general ${ }^{205}$, especificaciones acerca del trámite a seguir en las tercerías coadyuvantes (arts 1039), así como una

3) En general, si no existiesen entre el demandado y el tercero, otras defensa y derechos conducentes, ajenos a la litis, que no hubiesen sido materia de debate y decisión en el juicio.

4) En los casos previstos por el art.118 de la ley 17.418 y sus equivalentes, como consecuencia de la citación en garantía al asegurador. En tal caso la demanda deberá interponerse ante el tribunal del lugar del hecho o del domicilio del asegurador.

La sentencia que se dicte hará cosa juzgada respecto el asegurador y será ejecutable contra él en la medida del seguro. En este juicio o en la ejecución de la sentencia el asegurador no podrá oponer defensas nacidas después del siniestro.

También el asegurado puede citar en garantía al asegurador en el mismo plazo y con idénticos efectos.

${ }^{205}$ Encontramos allí disposiciones que hacen al sistema de tercerías de dominio (arts 1038 1/2 y 1040-incorporados por ley 3481) 
disposición que declara que la sentencia dictada después de la intervención de terceros, les obliga como a los litigantes principales (art.1043); además, contiene un dispositivo similar al del art.522 del Código de Procedimientos Civiles del Uruguay (ver punto 27); se trata del art.1038 ${ }^{206}$. Tal norma, subsistió bajo el mismo número, luego de la reforma introducida por la ley 6883 de 1983. Los Códigos de Procedimientos Civiles y Comerciales de Mendoza (ley 435 de 1896) art.649, San Juan (ley del año 1911) art.1013), Santiago del Estero (ley 1733 de 1941), art.702) y de San Luis (ley 310 de 1906), art.808, reproducen, con algunas variantes no esenciales, el art.1038 del mencionado código cordobés y también lo hacen con las modalidades con las que dicho ordenamiento regula la intervención voluntaria de terceros (tercerías excluyente y coadyuvante) evicción y tercería de dominio y mejor derecho. Alsina, refiriéndose a las disposiciones que de manera elíptica habilitan la citación a terceros, dice que "no se han dado a esas palabras su verdadero alcance y pasan desapercibidas porque no se reglamenta la oportunidad y forma de la citación. Por otra parte ninguno de ellos ha precisado la posición del tercero frente a los demás litigantes, respecto de los cuales, aun cuando se trate de un litisconsorte en la intervención adhesiva, constituye un parte independiente, cuyos actos de procedimiento no obligan a los otros sujetos de la relación procesal, como tampoco se halla obligado por los que éstos ejecuten. $^{, 207}$.

2069". CPCC Córdoba."Art.1038. Los que sin ser parte en un juicio pendiente tuvieran, sin embargo, en él un interés legítimo podrán intervenir en el procedimiento aun sin ser citados, cualquiera sea la estación y la instancia en que se encuentre.

${ }^{207}$ Alsina Hugo. Tratado..Citado,t.1,pg.594 
Mención especial merece el Código de Procedimientos en lo Civil y Comercial, proyectado por los Dres Cabal y Atienza, para la Provincia de Córdoba. (ley 2924 de 1940). El ordenamiento referido, considera las tercerías coadyuvante y excluyente y además una intervención de terceros prevista específicamente en el art.537 ${ }^{\mathbf{2 0 8}}$. La doctrina entendió que tal dispositivo negaba al tercero el carácter de parte, solución que Podetti encontraba "extraña" ${ }^{209}$ y Alsina sostenía que al no darle aquella categoría le hacía perder toda eficacia práctica ya que dicho sujeto no sería afectado por la cosa juzgada ${ }^{\mathbf{2 1 0}}$. Nosotros entendemos que el dispositivo lejos está de no considerar parte al tercero luego de su ingreso: solamente dice que quien no lo era, puede sin embargo participar del juicio y nos resulta claro que quien lo hiciera en nombre de un interés legítimo podría, en adelante, actuar como parte. El dispositivo no solamente se alinea con el art.1038 CPC, sino también con el art.1042 CPC de esa provincia (leyes 1919 y 3481) ${ }^{211}$. A la vez, el mismo principio y posibilidades recursivas aparecen consignadas en los arts 359, segunda parte CPCC Córdoba vigente, 242 C.G.P Uruguay y 297 CPC Venezuela.

\footnotetext{
${ }^{208}$ Art.537. Todo el que sin ser parte en juicio tenga interés legítimo en su solución, podrá intervenir espontáneamente o ser citado a los mismos fines de oficio o a petición de parte tomando el proceso en el estado en que lo encuentre.

${ }^{209}$ Podetti J.Ramiro. Obra citada , pg.27

${ }^{210}$ Alsina Hugo.Tratado.. citado pg.594

${ }^{211}$ Art.1042. El que tuviera interés legítimo en una causa podrá, aun antes de entablar tercería, interponer recursos legales, siempre que lo haga dentro del término en que puedan hacerlo los que litigan"
} 
El proyecto de Código de Procedimiento Civil y Comercial elaborado por los Dres Enoch Aguiar y Angel H.Cabral, (1940) ${ }^{\mathbf{2 1 2}}$ regula la intervención de tercero voluntaria o coactiva, los efectos del llamamiento y las modalidades de actuación del interviniente ${ }^{213}$. Dedica los arts 68 a 70 a la "Evicción y saneamiento" haciendo aplicable a la misma el régimen establecido en general para el llamamiento a juicio de terceros.

212 ) Se trata del proyecto traducido en ley 3931 de la Provincia de Córdoba, que aprobó el Código de procedimiento civil y comercial para ese estado y que fuera derogado por la ley 4127.

213)El art.46 establece que la actuación de varios sujetos con derechos análogos determina la presencia de un litisconsorcio y requiere la unificación de representación

art.56. Todo aquél que sin ser parte en un juicio, tenga en él un interés legítimo, puede intervenir como tercero, en cualquier estado del trámite, ya sea voluntariamente o por emplazamiento.

En el primer supuesto del párrafo anterior, queda el tercero ligado al proceso y a las consecuencias del juicio. Asimismo lo estará en el segundo, si fuere llamado antes de trabado el pleito y en tiempo hábil para ser oído.

Art.57. El emplazamiento del tercero suspenderá el procedimiento hasta su comparecencia o hasta que, vencido el término de su emplazamiento, se le dé por decaído el derecho de intervenir en el juicio y se le notifique el auto respectivo.

Art.58. El tercero dentro del término del emplazamiento puede impugnarlo y la impugnación será resuelta, previa información oral.

Art.59. El que concurriere por emplazamiento será oído después de la intervención del demandado"

En ambos casos, cuando el interés del tercero fuera coincidente con el de algún de las partes, y no lo hubiese hecho valer como tercerista regirá lo dispuesto en el artículo 46. 
El proyecto regla las tercerías de dominio y mejor derecho en los arts.63 a 67.

El Proyecto de Código de Procedimiento Civil y Comercial para la Provincia de Buenos Aires, preparado por el Instituto de Altos Estudios Jurídicos de la Facultad de Ciencias Jurídicas y Sociales de la Universidad Nacional de La Plata en 1935, dirigido por David Lescano, no contiene disposiciones referidas intervención de terceros, salvo la citación de evicción (art.174) ${ }^{\mathbf{2 1 4}}$ y los juicios de tercería de dominio y de mejor derecho.(art.261 a 263).

El Anteproyecto de Código Procesal Civil y Comercial para la Provincia de Salta del Dr.Ricardo Reimundin ${ }^{215}$ contempla la intervención voluntaria (arts.59 y 60) la coadyuvante (art.61),la excluyente (art.62) y la obligada (art.63 a 68), ${ }^{216}$, la "Citación de evicción y saneamiento"( arts. 75 a 81$)^{217}$.

${ }^{214}$ Dentro de los primeros siete días de notificada la demanda, podrá el demandado usar del derecho de citar de evicción, a cuyo efecto deberá indicar el nombre, domicilio y demás circunstancias del enajenante, a quien se le notificará la demanda y se le emplazará para que se presente a estar a derecho dentro del término de veinte días. Esta citación sólo se hará resultando notoriamente procedente el pedido"

Si el citado no compare se entenderá el juicio con el primer emplazado"

${ }^{215}$ Reimundín Ricardo. La reforma procesal civil en la Provincia de Salta. Salta. 1948

${ }^{216}$ Art.63. Intervención obligada. El actor al proponer la demanda, y el demandado dentro del plazo para oponer excepciones dilatorias, podrán pedir la citación de aquél a quien consideren común la controversia, debiendo emplazársele en la forma ordinaria. El interviniente será oído después de la contestación de la demanda del demandado. Las resoluciones serán apelables en relación.

Art.64. Suspensión del procedimiento por emplazamiento del tercero. El emplazamiento de un tercero, suspenderá el procedimiento hasta su comparecencia o hasta que, vencido el 
emplazamiento, se le dé por decaído el derecho de intervenir en el proceso y se le notifique el auto respectivo. La resolución será apelable en relación.

Art.65. Impugnación del emplazamiento. El tercero, dentro del emplazamiento, puede impugnarlo la impugnación se tramitará en la forma establecida para los incidentes.

Art.66.En los casos en que proceda la suspensión del proceso principal cualquiera de las partes podrá pedir su continuación independiente cuando resulte manifiesto que el tercero procede sin derecho y sólo para obstaculizar el procedimiento. La resolución será apelable en relación.

Art.67. Posición del tercero frente a los otros litigantes. Salvo disposición en contrario, el interviniente será considerado como parte distinta de los otros litigantes y sus actos no perjudicarán ni aprovecharán a los otros.

Art.68. Efecto de la intervención. La sentencia dictada después de la intervención del tercero, o de su citación en su caso, lo afectará como a los litigantes principales.

${ }^{217}$ Artículo 75. Oportunidad para solicitarla. Tanto el actor como el demandado podrán solicitar de evicción y saneamiento, el primero al entablar la demanda y el segundo dentro del plazo señalado para contestarla.

Artículo 76. Formas y efectos de la citación. El tercero será llama do en la misma forma y plazo que el establecido para el demandado y se decretará sin sustanciación alguna.

La citación solicitada en tiempo suspende el curso del proceso durante el plazo de veinte días a fin de que el citante haga practicar las diligencias necesarias para el conocimiento del citado.

No se suspenderá, mientras tanto, el plazo ni la tramitación de las excepciones dilatorias. La resolución será apelable en relación.

Artículo 77.Defensa de la causa por el citado. Si se presentare a efecto de hacer la defensa, podrá obrar conjunta o separadamente de aquél que pidió la citación, asumiendo el rol que le corresponda como parte en el proceso.

Si el citado se resistiese a tomar la defensa de la causa, se seguirá ésta con el que pidió la citación, salvo los derechos de éste contra aquél.

El citante, no obstante la continuación del juicio podrá seguir haciendo las gestiones necesarias para el comparendo del citado. 
En julio de 1997 los Dres.Arazi, Kaminker, Eisner y Morello presentaron a la Secretaria de Justicia de la Provincia de Buenos Aires, un proyecto de Código Procesal Civil y Comercial que prevé la intervención obligada de terceros en los mismos términos que contiene el art.94 CPCPCN, (art.94); la citación a pedido de parte, o de oficio, en caso de fraude o colusión y (art.95) y los alcances de la sentencia ${ }^{218}$.

Si éste compareciere, tomará la causa en el estado en que se encuentre.

Artículo 78. Derecho del citado para llamar a su causante. Si el citado pretendiese citar a su vez a su causante, podrá hacerlo dentro de los primeros seis días de su emplazamiento, sin perjuicio de la obligación de seguir la causa por sí mismo.

Artículo 79. Citación de dos o más causantes. Podrá solicitarse a la vez la citación de dos o más causantes en la cosa litigiosa.

Artículo 80. Intervención del garantido. No obstante la asunción de la defensa del garantido por el citado, aquél podrá intervenir en el proceso, en la forma determinada para la intervención de terceros.

Artículo 81. Cuestiones entre citantes y citado. El citado no podrá alegar la improcedencia de la citación, formando incidente, debiendo limitarse a hacer o no hacer la defensa. Llegado el caso de responsabilidad, recién podrá ventilarse este punto en el juicio que corresponda

${ }^{218}$ Art.96. Alcance de la sentencia .Recursos. En todos los supuestos, la sentencia dictada después de la intervención de terceros o de su citación, en su caso, lo afectará como a los litigantes principales. Será ejecutable a su respecto:

1) Si al sustanciarse el pedido de intervención el actor hubiera adherido y solicitado la condena de un tercero.

2) En los casos previstos por el art.118 de la ley 17.418, y sus equivalentes.

3) En general si no existieren entre demandado y tercero otras cuestiones o derechos conducentes, ajenas a la litis, que no hubiesen sido materia de debate y deducidas en juicio. 


\section{Fuentes del CPCCN}

En la materia tratada y como lo vamos a ver, constituyen fuentes argentinas del CPCCN los Códigos Procesales Civiles y Comerciales de La Rioja y Santa Fe, y Códigos Procesales Civiles de Jujuy y Mendoza, que mantienen su vigencia en la actualidad. Como podrá observarse, sus respectivas redacciones presentan diferencias con la nacional con disposiciones que se analizarán brevemente sin perjuicio de las referencias a realizar junto con el tratamiento de la normativa nacional.

a) CPC Jujuy. El Código Procesal Civil de la Provincia de Jujuy, trata la "Intervención de terceros" en el Capítulo IV, del título II. Regula la intervención voluntaria, la coadyuvante y la excluyente,(arts 75 a 78) pero también la intervención obligada tercero, sujeto cuya citación suspenderá el procedimiento hasta su comparecencia o hasta que vencido el plazo fijado al efecto ${ }^{\mathbf{2 1 9}}$ y las de dominio y derecho (arts 83 a 89 ) y en el capítulo siguiente, se trata la evicción y saneamiento (arts 90 a 95).

Será inapelable la sentencia que admita la intervención de tercero.

La que la deniegue será apelable en ambos efectos si fuere el caso del art.94 y devolutivo en los demás

${ }^{219}$ Art.79. Intervención obligada. El actor en el escrito de demanda y el demandado dentro del lazo para oponer excepciones previas, podrán pedir se de intervención al que consideren común la controversia, debiendo emplazársele o citársele en la forma ordinaria. 
Destacamos que la ley jujeña permite al citado impugnar la citación (art.80) y en su intervención le condición de parte distinta de los otros litigantes (art.82) .El Código Jujuy, denomina“ Evicción y saneamiento” al Capítulo VI, Título II, Libro I y la misma conjunción utiliza en el art.90 ${ }^{\mathbf{2 2 0}}$.

El tercero interviniente será oído después de la contestación de la demanda

Art.80. Emplazamiento al tercero. El emplazamiento o citación de un tercero, suspenderá el procedimiento hasta su comparecencia o hasta que vencido el plazo respectivo, se le dé por decaído el derecho de intervenir en el juicio.

El tercero, dentro del plazo del emplazamiento o citación, puede impugnarlo y la impugnación se tramitará en la forma establecida para los incidentes.

Art.81. Continuación del proceso principal. En los casos en que proceda la suspensión del juicio principal, cualquiera de las partes podrá pedir su continuación independiente cuando resulte manifiesto que el tercero actúa sin derecho y sólo para obstaculizar el procedimiento

Art.82. Efectos de la intervención .Salvo disposición en contrario, el interviniente será considerado como parte distinta de los otros litigantes y sus actos no perjudicarán ni aprovecharán a los demás.

La sentencia dictada después de la intervención del tercero, o de su citación o emplazamiento en su caso, lo afectará como a los litigantes principales

${ }^{220}$ Art.90. Oportunidad. Tanto el actor como el demandado podrán solicitar la citación de evicción y saneamiento: el primero antes o al tiempo de entablar la demanda; el segundo, dentro del plazo para oponer excepciones previas si se tratare de juicio ordinario o dentro del fijado para la contestación en los demás procesos".

Art.91.Forma y efectos. El tercero será llamado en la misma forma y plazo que el establecido para el demandado y se decretará sin sustanciación laguna.

La citación solicitud en tiempo, suspende el curso del proceso durante veinte días, a fin de que el citante haga practicar las diligencias necesarias para el conocimiento del 
b) CPC La Rioja. El Código Procesal Civil y Comercial de la Provincia de la Provincia de La Rioja trata de la intervención de terceros en los arts 145,146 y $147^{221}$.

citado. No se suspenderá, mientras tanto, el plazo ni la tramitación de las excepciones previas."

Articulo 92. Defensa por le citado .Si el citado asumiere la defensa podrá obrar conjunta o separadamente con aquel que pidió la citación. No obstante que el citado realice la defensa, puede el que pidió la citación actuar en el proceso en la forma determinada para la intervención de terceros".

Artículo 93. Citación de otros causantes. Si el citado pretendiese citar a su vez a su causante, podrá hacerlo dentro de los primeros diez días de su emplazamiento, sin perjuicio de la obligación de seguir el proceso por sí mismo. En las mismas condiciones puede cada uno de los causantes en la cosa litigiosa, hacer citar a su causante respectivo."

Art.94. Abstención y tardanza del citado. Si el citado no compareciere o habiendo comparecido se resistiere a asumir la defensa, el juicio proseguirá con quien pidió la citación, salvo los derechos de éste contra aquél.

Durante la sustanciación del juicio, las dos partes podrán proseguir las diligencias para obtener la comparecencia del citado. Si éste se presentare, tomará la causa en el estado en que se encuentre. “

Art.95.Cuestiones entre citantes y citados. El citado no podrá alegar la improcedencia de la citación, formando incidente, debiendo limitarse a hacer o no hacer la defensa. Llegado el caso de responsabilidad recién podrá ventilarse este punto en el juicio que corresponda."

${ }^{221}$ Art.145.Reglas generales. El que solicitare intervención en juicio , en calidad de tercero, deberá invocar un interés legítimo.

La parte que pidiera la intervención coactiva de un tercero, deberá indicar los motivos por los cuales considera que la controversia es común. 
Según tales disposiciones, la intervención de tercero en un proceso puede darse por a) tercería de dominio, posesión o preferencia (art.149), b) intervención excluyente, que puede ser voluntaria o coactiva (arts 146 y

En todo lo que se refiera al trámite de las tercerías, se aplicarán en lo pertinente, las normas previstas para los incidentes.

En todos los supuestos, la sentencia dictada después de la intervención del tercero, o de su citación, en su caso, lo afectará como a los litigantes principales.

Art.147. Intervención coactiva del tercero excluyente. La intervención coactiva del tercero excluyente podrá ser dispuesta de oficio o a pedido de partes. La solicitud deberá formularse por el actor en el escrito de demanda y por el demandado dentro del término para oponer excepciones y se resolverá sin más trámite, disponiéndose la citación del tercero, salvo que apareciera manifiesto que ella fue pedida con el propósito de dilatar u obstaculizar el procedimiento. El tercero será emplazado a comparecer al juicio y a contestar la demanda en el término previsto para tal efecto. Si el mismo cuestionara su intervención, la oposición se sustanciará por el trámite de los incidentes.

A todos los efectos del proceso, el actor, el demandado y el tercero serán considerados partes distintas y opuestas entre sí.

Art.148. Intervención coactiva del tercero coadyuvante. El pedido de un tercero, para actuar como coadyuvante de alguna de las partes, se tramitará en la misma forma establecida para el pedido de intervención voluntaria del tercero excluyente. La intervención coactiva del tercero coadyuvante se dispondrá, de oficio o a petición de parte, en la misma forma establecida para la intervención coactiva del tercero excluyente.

En todos los casos, el tercero tendrá las mismas facultades procesales de la parte a la que coadyuva, y actuará como litis consorte de ella, pudiendo llegar a sustituirla quedando como parte principal y la originaria como coadyuvante, pero la exclusión total del proceso, de dicha parte, sólo podrá producirse mediante expresa conformidad de la contraria. 
147), c) intervención coadyuvante que también puede dividirse en iguales categorías que la anterior. La ley establece que tanto los coadyuvantes voluntarios como los coactivos serán considerados litisconsortes, es decir, partes $^{222}$; si el llamado se declarara procedente, el coadyuvante deberá ajustarse en su actuación a las limitaciones referidas y a la que resulta ,precisamente, de su rol de ayudante y no de contradictor salvo que, siendo demandado, el actor ampliase su demanda involucrándolo o si habiéndosele llamado al campo actor, pudiere actuar como tal por ser co-titular de la misma relación jurídica sustancial. En lo demás, el tercero citado coactivamente -equivalente a los supuestos del art.96(94) y 107(105) CPCCN- operará con dicha calidad. Obsérvese que según el código riojano, el tercero puede llegar a sustituir al convocante pero sin que éste quede habilitado para alejarse del juicio, salvo expresa conformidad de la contraria. No lográndose esa conformidad la sustitución convierte al citante en coadyuvante sin que por ello pierda condición de parte activa y sometido como tal a la sentencia que se dicte (art.146 cuarta parte). En esas condiciones el coadyuvante tendrá limitaciones: así, no puede disponer del objeto del litigio -allanarse, desistir, transar o conciliar salvo que asuma contractualmente las consecuencias y tenga la conformidad del coadyuvado-; al que como coadyuvante no puede enfrentarse.

c) CPC Mendoza. El CPC de la Provincia de Mendoza, rige en esa provincia a partir de 1954 (ley 2269). El Libro primero, Título II, "De los sujetos del proceso y de sus auxiliares", Capítulo I. "Actor demandado, terceristas, reglas generales". Capítulo II "Sucesión procesal” Capítulo III

\footnotetext{
${ }^{222}$ Entendemos que la remisión del art.147 a la figura del art.147 -tercero excluyenteautoriza, tal como ocurre con éste, a tenerlo como parte distinta del coadyuvado y de su oponente y a permitir que el citado discuta con el citante la procedencia de la convocatoria, por vía incidental-art.145.
} 


\section{"Sustitución procesal" donde se regula la acción subrogatoria (art.28), pero antes el llamado en garantía (arts.25, 26 y 27) ${ }^{223}$. El Código incluye la}

\footnotetext{
${ }^{223}$ Art.25. Llamado en garantía.1.-Cuando un litigante tuviere derecho a pedir la defensa o garantía de un tercero, respecto al objeto material de la litis, podrá solicitar su citación, antes o juntamente con la demanda o diez días después de agregada la contestación si de ella surgiere la necesidad de la citación, tratándose de actor; y dentro de los diez primeros días del emplazamiento para contestar la demanda, la reconvención o para comparecer, en caso de demandado, reconvenido o tercerista citado. Si el emplazamiento fuere menor, deberá pedirse la citación antes o en el acto de ser contestada la demanda.
}

II. Si del documento con que se instruya la petición, surgiera "prima facie", el derecho invocado, se suspenderá el procedimiento, mientras se notifica la citación y vencen los plazos. De no ser sí, se dispondrá la citación, pero no se suspenderá el procedimiento.

III. En todo caso la citación se decretará sin trámite previo alguno y sin que pueda objetarla el otro litigante.

IV.El citado podrá a su vez, en el mismo plazo y con los mismos efectos, solicitar la citación de otros garantes.".

Art.26. Plazos para comparecer.

I.-Si la citación se pidiere por el actor, el citado deberá comparecer al proceso dentro de los diez días de la notificación, y podrá modificar o ampliar la demanda si hubiera sido deducida por el citante o deducirla, de lo contrario, en el mismo plazo (ley 2637).

II-Si la citación se pidiere por el demandado, el citado comparecerá y contestará la demanda en el plazo concedido a su citante, contado a partir de la notificación al citado.

III-Si la citación se pidiere por uno de los citados, el plazo será el que corresponde al primer citado, conforme al primero o al segundo apartado.

IV. Iguales reglas se aplicarán si se trata de terceros llamados al proceso por iniciativa de los litigantes".

Art.27. Responde, facultades y cargas. 
evicción en un amplio espectro del llamado en garantía y la considera como una modalidad de sustitución procesal; la suspensión del procedimiento inmediata a la petición, solamente procederá si el requerimiento se basa en prueba documental y tuviese suficiente contundencia. El pedido se resuelve sin sustanciación y sin dar lugar a impugnación. El tercero podrá pedir la citación de otros garantes. Se consagra la carga de comparecer cuyo incumplimiento si bien no generará sanciones, hará perder el derecho a ingresar en el momento inicial del proceso, sin perjuicio de poder tomarlo posteriormente en el estado en que se encuentre; el tercero que concurra debe hacerlo contestando la demanda con posibilidades de sustituir o de coadyuvar con el citante, según el caso , $\mathrm{y}$ en tal situación la de estar dotados de facultades y cargas que correspondan a cada uno de los extremos de aquella alternativa.

El título V, "De las tercerías", comprende "Normas Comunes" (Capítulo I)- arts 103 y 104-, “Tercerias excluyentes" (Capítulo II)-arts 105 a 108- y "Tercerías coadyuvantes" Capítulo III, arts 109 a 111. La intervención de terceros puede excluyente o coadyuvante; en ambos casos puede darse por intervención espontánea o por citación a iniciativa de

I. Vencido el plazo de la citación o de las citaciones sucesivas, conforme al artículo 26, sin que el citado asuma el carecer de litigantes, automáticamente seguirá corriendo el plazo concedido al citante.

II. Los citados que comparezcan tendrá las facultades y cargas procesales que les correspondan, según sustituyan al citante o coadyuven con él, pero aun en el primer caso, éste continuará en el proceso a los fines de la absolución de posiciones y reconocimiento de firmas.

III. Si comparecieren tardíamente, tomarán el proceso en el estado en que lo encuentren.

IV. Su incomparecencia no les traerá aparejada ninguna sanción procesal, sin perjuicio de los derechos que por ley o convención tenga el citante, los cuales no podrán discutirse en el proceso donde se pidió la citación". 
partes o de oficio. El interviniente coadyuvante puede asumir ese papel o también sustituir según el caso. Como coadyuvante actuará como litisconsorte del coadyuvado con sus mismas facultades procesales. Si sustituye, el sustituido pasa a coadyuvar con el sustituto y puede ser excluido del proceso con la conformidad del adversario ${ }^{224}$.

${ }^{224}$ Art.103: Reglas generales. La intervención de terceros en un proceso pendiente, sea espontáneo o por citación a pedido de litigantes o de oficio, se ajustará a las normas establecidas en este código, con las modificaciones que contiene este capítulo.

En cuanto sea pertinente, se aplicarán también las reglas específicas que corresponden al caso de litisconsorcio voluntario o necesario (arts 43,44 y 45), a la sucesión y a la sustitución procesales.

En todo caso, la sentencia tendrá efectos de cosa juzgada en contra o a favor del tercero interviniente.

Art.106. Trámite de la tercería espontánea excluyente. El tribunal sin sustanciación, admitirá o rechazará la intervención en auto inapelable para la primera situación y apelable para la segunda.(ley 2637).

En caso de admitirse la intervención ,el tribunal establecerá si ha de sustanciarse en el mismo expediente o por separado y en ese último supuesto, el trámite que debe seguir, según la importancia y naturaleza del pleito principal y de la tercería y si ha de suspenderse el principal y en qué estado. La suspensión procederá siempre que la prosecución del trámite pueda ocasionar al tercerista un perjuicio irreparable dentro del proceso, como en el caso de tercería de dominio de mejor derecho y otros análogos.

Art.107. Intervención coactiva. Los terceros excluyentes citados a comparecer por pedido de litigantes originarios o de oficio, tienen el ejercicio de todas las facultades procesales, desde la demanda o responde, según su situación.

Cuando la citación haya sido pedida por uno de los litigantes originarios, se procederá como lo dispone el artículo precedente.

Siendo la citación de oficio para integrar la litis ,se suspenderá el procedimiento hasta que venza el plazo de aquélla y se sustanciará en el mismo expediente. 
d) CPCC Santa Fe. El Código Procesal Civil y Comercial de Santa Fe, dedica el Título VI del Libro II a la "Intervención de terceros". Dentro de tal título la Sección I es de Disposiciones generales (arts 301 a 305) referidas a las intervenciones excluyentes, coadyuvantes y por litisconsorcio necesario; el art.305 regula estas últimas, pero también la provocada que se da "si de acuerdo a las leyes de fondo, la relación en litigio fuera presupuesto de una obligación del tercero para con una de las partes". La norma especifica que la incomparecencia del citado le impedirá cuestionar la actuación de su eventual acreedor ${ }^{225}$. La Sección II, regula la intervención en juicio declarativo y si bien en ella se refiere a las

Art.110. Intervención coactiva del litigante. Los terceristas coadyuvantes citados a comparecer a pedido de los litigantes originarios, tendrán los mismos derechos de los excluyentes, aplicándose lo dispuesto por los dos primeros apartados del artículo 107.

Art.111. Posición procesal del tercerista coadyuvante. El tercerista coadyuvante actuará como litisconsorte de aquel a quien ayuda y tendrá sus mismas facultades procesales.

Podrá sustituir a quien pidió su citación, manteniendo éste la posición de litigante, coadyuvando con su sustituto. La exclusión de este último del litigio, requiere la conformidad expresa de la contraria.

${ }^{225}$ CPCC Santa Fe. Art.305. Excepto los casos especialmente previstos por ese código sólo podrá llamarse a un tercero a juicio, por pedido de parte o de oficio, en caso de litisconsorcio necesario .Pero sí, de acuerdo con las leyes de fondo, la relación en litigio fuera presupuesto de una obligación del tercero para con una de las partes, ésta podrá pedir igualmente que se lo cite. La incomparecencia hará inadmisible toda alegación relacionada o que se funde en las actuaciones procesales de su eventual acreedor.

La citación deberá pedirse al entablar la demanda o antes de oponer excepciones o al contestarlas y el emplazamiento se realizará en forma ordinaria.

Cuando el llamamiento se funde en la necesidad del litisconsorcio, el tercero podrá oponerse a su intervención, en cuyo caso el incidente paralizará el procedimiento principal hasta que sea resuelto aquél. 
intervenciones coadyuvantes y excluyentes, nos parece claro que entre las primeras debe computarse la obligada con sentido de apoyo a la posición del citante, razón por la que corresponderá al tercero condición de parte (art.302), así como ser alcanzado por la cosa juzgada referida por el art.305 ${ }^{226}$.La Sección III trata de la Citación de saneamiento ${ }^{227}$.

${ }^{226}$ Art.302. Si la sentencia que se dicte en un proceso ha de producir efectos jurídicos directos en la relación jurídica existente entre una de las partes, o las dos, y un tercero, o si la ejecutabilidad de aquélla ha de extenderse a bienes de éste el tercero puede intervenir en el proceso como parte, conforme con lo dispuesto al reglar la tercería coadyuvante en juicio declarativo.

Igual intervención le corresponderá cuando su derecho sea conexo con el deducido en el proceso por la parte a que coadyuve.

Art.308. La sentencia dictada obliga a los terceros como a los principales.

${ }^{227}$ Artículo 309: Tanto el demandante como el demandado podrán solicitar la citación de saneamiento; el primero, al entablar la demanda o antes de deducirla y el segundo, dentro del término para contestarla."

Artículo 310: El decreto que ordene la citación se dictará sin ningún trámite y será notificado como el emplazamiento.

La citación de saneamiento solicitada en tiempo suspenderá el curso de la causa, pero no el término ni la tramitación de las excepciones dilatorias.

Artículo 311. Si el citado no compareciere o si compareciendo se resistiere a tomar la defensa de la causa, se la seguirá con el que pidió la citación, salvo los derechos de éste contra aquél.

Las dos partes, no obstante la continuación del juicio, podrán seguir haciendo las gestiones necesarias para el comparendo del citado. 


\section{Codificaciones diferenciables}

a) Reseña. Dictado el CPCCN, fuera de los Códigos que señalamos como fuentes del ordenamiento nacional que mantuvieron sus textos, el resto de las provincias argentinas adoptaron y luego siguieron -algunas con variantes- la regulación nacional; por ende, también ese fenómeno se manifestó en materia de intervención de terceros, tanto voluntaria como coactiva y en especial obligada .Ello ocurrió incluso con las codificaciones aparecieron en el panorama argentino con posterioridad a la vigencia del CPCCN (CPCC Corrientes, La Pampa, Río Negro, Santiago del Estero, San Juan). Sin embargo, escapó a ese panorama el CPCC de la Provincia de Tierra del Fuego.

b) CPC Tierra del Fuego. Sabido es que la Provincia de Tierra el Fuego, adoptó prácticamente a la letra el Código Modelo para Iberoamérica

Si éste compareciere tomará la causa en el estado en que la encuentre. El citado podrá oponer en la contestación las excepciones dilatorias que no hubieran sido opuestas como artículo previo.

Artículo 312: Si el citado pretendiese citar a su vez a su causante, podrá hacerlo dentro de los cinco días siguientes al de su comparendo, sin perjuicio de la obligación de seguir la causa por sí mismo.

En las mismas condiciones podrá cada uno de los causantes hacer citar a su causante respectivo.

Art.313. Será ineficaz la citación que se hiciere sin la antelación necesaria para que el citado pueda comparecer antes de la sentencia de primera instancia. 
elaborado por el Instituto Iberoamericano de Derecho Procesal y a su réplica el CGP Uruguay.

Se asigna calidad de partes a actor, demandado y a los terceros "pero en los casos previstos por éste Código" (art.56).Se regula la intervención voluntaria de terceros coadyuvante (art.100.1) y la litisconsorcial (art.100.2). En cuanto a la coactiva refiere la intervención necesaria por citación (art.103), aparte del llamamiento de oficio, a pedido de parte o del ministerio público en caso de fraude o colusión (art.105). El artículo 106.2 establece que en el supuesto del art.103, el tribunal suspenderá el procedimiento por el plazo de emplazamiento del citado. El art.107 extiende a los terceros, los alcances de la sentencia ${ }^{228}$. En cuanto al procedimiento a seguir -proceso por audiencias-, en la de naturaleza preliminar, si se dispone la citación del tercero, se procederá a su emplazamiento disponiéndose entonces la suspensión de la audiencia, que luego se reanudará con el procedimiento de prueba (art.371.8 y 9).

\section{SECCION SEGUNDA}

\section{CONCEPTO. CLASES. DIFERENCIACIONES}

${ }^{228}$ Art.103. Intervención necesaria por citación. El actor en el escrito de demanda y el demandado, en el plazo 'para contestar y sin perjuicio de hacerlo podrá solicitar el emplazamiento del tercero en garantía o de aquél respecto al cual considerar que la controversia es común o a quien la sentencia puede afectar .El emplazado no podrá objetar la procedencia de su emplazamiento y deberá comparecer, tendrá los derechos, deberes y cargas que resulten, según sea el tipo de su intervención.

Art.104. Oposición al llamamiento de terceros. La contraparte podrá oponerse a la citación de un tercero y el Tribunal resolverá la procedencia de la misma por sentencia interlocutoria, que sólo será apelable cuando rechace la intervención. 


\section{Concepto}

Identificada básicamente como una forma de intervención coactiva como lo hicimos en el punto 13 , perfilada con mayor precisión en el punto

14 y recordando las definiciones de la intervención obligada formuladas por caracterizada doctrina nacional ${ }^{229}$, diremos que la intervención obligada de terceros, es una institución que se manifiesta cuando un sujeto que permanece alejado de un proceso, pero que está vinculado a una de las partes por una relación jurídica sustancial conexa con la debatida, por iniciativa de aquélla y mediante la denuncia de litis, queda sometido a la cosa juzgada resultante de ese juicio, y entonces, sin constituirse en actor o demandado sino manteniéndose en su condición de tercero, queda en aptitud de participar del debate de la cuestión que resulte común a ambas relaciones .

229 "La intervención obligada, también llamada coactiva, provocada o forzosa, tiene lugar cuando en un proceso pendiente (entre otras partes) el juez, a pedido de una de las partes, ordena la citación a un tercero. El tercero se ve así llamado a intervenir por iniciativa ajena en un proceso en curso"( Fassi Santiago C.-Yañez César D. Código Procesal Civil y Comercial. Comentado, anotado y concordado, Tercera edición, T.1 pg.523.Astrea.Buenos Aires. 1988.), pero también: "En la Exposición de motivos se aclara que la figura de la intervención obligada (art.94) comprende aquéllas hipótesis en las cuales la parte eventualmente vencida tenga un acción regresiva contra el tercero ,o medie conexidad entre la relación controvertida en el proceso y otra existente entre el tercero y alguna de las partes originarias" (Arazi Roland -Rojas Jorge A. Código Procesal Civil y Comercial de la Nación, Comentado, anotado y concordado con los códigos provinciales. T.I, pg.374. Rubinzal-Culzoni. Santa Fe.2001.) "En términos generales, la intervención coactiva u obligada se verifica cuando, sea a petición de cualquiera de las partes originarias o de oficio, se dispone la citación de un tercero para que sea participe en el proceso pendiente y la sentencia a dictar en él pueda serle eventualmente opuesta" (Palacio Lino E. Derecho ..citada,t.III,pg211 a 213). 
La intervención obligada puede darse por concurrencia o por abstención, en el primer caso el tercero operará como coadyuvante del litisdenunciante.

Destacamos desde ya los elementos integrantes de nuestra conceptualización: calidad de tercero, relación sustancial conexa, cuestión y controversia común, citación ,cosa juzgada.

\section{Intervención obligada y litisconsorcio necesario}

El CPCCN -y en general las legislaciones que consideramos- separan el caso del litisconsorcio necesario (art.91(89)) CPCCN) de los que hacen a la intervención obligada de terceros ${ }^{230}$. En nuestro medio, encontramos criterios que sostienen la unidad esencial de ambas figuras ${ }^{231}$ en oposición a los que coinciden con la diferenciación de la ley ${ }^{232}$.

Entre la intervención referida y el sistema inherente al litisconsorcio necesario, se presenta una importante similitud pues en ambos, tanto el tercero como el litisconsorte han de participar del juicio desde su etapa

\footnotetext{
${ }^{230}$ Ya señalamos ( punto 18) como en la doctrina italiana relativa al CPC de 1865 se consideraba que tenían tratamiento legislativo conjunto, en tanto el actual código peninsular le da consideración separada.

${ }^{231}$ La citación del art.94 CPC Buenos Aires, no es sino un supuesto que genera una modalidad de litisconsorcio necesario (art.89); así lo tiene resuelto la SCJ Buenos Aires 5/2/85 Duhalde y Cía S.A.Pedro..Ac.33.130 L.L.1985-C,355).

${ }^{232}$ Kenny Héctor Eduardo. Obra citada,pg.76. "La intervención obligada del tercero no importa la constitución de un litisconsorcio necesario, ya que el actor goza de plena libertad para elegir a la persona que ha de demandar .."(CN Civ. Sala F.25/9/73 E.D.52300.)
} 
constitutiva-o por lo menos antes de comenzar la probatoria- de modo que a diferencia de los intervinientes voluntarios no están obligado a tomar el juicio en el estado en el que se encuentre (arts. (93( 91) y 96(94) CPCCN). Por lo demás, la sentencia que se dicte tendrá alcance y sentido uniforme para todas las partes si bien en el caso del art.96 estará ceñido a la cuestión común. Pero, las diferencias resultan ser de mayor importancia: en el litisconsorcio necesario, la presencia de todos los sujetos de la relación sustancial, es condición para la validez del fallo ya que ante la falta de integración, ha de ser inútil para quien quisiere utilizarlo ya que resultará inaplicable a los excluidos. Sin embargo, debemos resaltar que no siempre la existencia de pluralidad de integrantes de la relación sustancial impone la necesidad de litisconsorcio; dependerá de la pretensión que esté en juego ya que en diversos casos, la que ejercite uno puede satisfacer el interés de sus cotitulares tornando innecesaria la concurrencia de todos al juicio. Así por ejemplo, cualquiera de los titulares de dominio puede promover la acción de reivindicación (arts.2772 Cód.Civil, 2251 segunda parte CCCN) o el cobro de acreencias correspondientes a obligaciones solidarias (arts.705 Cód.Civil,840 CCCN) o indivisibles (arts.686 Cód.Civil,820 CCCN).

Como lo expresamos en el punto 1, la presencia de esa totalidad podrá darse en el comienzo del pleito o bien si a posteriori se integra la litis mediante su citación. En la conformación adecuada del litisconsorcio, está presente el interés de las partes -fundamentalmente del demandante-pero también el interés público destinado a lograr una eficaz y armónica actuación jurisdiccional.

De ahí que el llamamiento podrá darse a instancia de los litigantes o de manera oficiosa, procedimiento que se evitará si el sujeto faltante concurre al juicio por propia iniciativa. La citación importa una 
convocatoria de ineludible concurrencia ya que pesa sobre el citado la carga de comparecer al proceso, de modo que su ausencia generará la consiguiente declaración de rebeldía si el domicilio resultaba conocido, así como de no serlo y citarse por edictos, procederá la participación del Defensor Oficial. Sin embargo, la citación en sí no genera ni predetermina el litisconsorcio sino que éste deberá conformarse cuando concurran los sujetos, pues ineludiblemente se verán compelidos a encolumnarse en una de las dos posiciones del juicio ${ }^{233}$.

En la intervención obligada del CPCCN, por el contrario, existe un tercero, es decir alguien ajeno a la relación procesal primitiva cuya presencia en el juicio no es imprescindible, ya que el fallo no precisa de tal concurrencia para ser válido y cumplir con la utilidad buscada por los litigantes iniciales, amén de que dicho tercero deba pertenecer a una relación jurídica sustancial conexa con la debatida (por ejemplo el tercero pretendiente, el garante de evicción) y no a la misma. El interés o la visión de los litigantes excluye el interés público; de ahí que la convocatoria sea manejada exclusivamente por las partes que, obviamente, sopesarán su beneficio en producir o no el llamamiento.

\footnotetext{
${ }^{233}$ Así por ejemplo, ante el pedido de declaración de filiación matrimonial, la relación jurídica sustancial se compone de tres sujetos A,B y C .Al demandarlos A, B y C pueden coincidir entre sí por oponerse al demandante y así, se constituirán ineludiblemente en litisconsorte aunque ambos sujetos pasivos discrepen en los fundamentos de su oposición ;por ejemplo si en una demanda por filiación matrimonial, el padre negare la paternidad, la madre en cambio admitiese la maternidad pero con otra paternidad, el litisconsorcio se produciría entre ambos progenitores que enfrentarían la posición del actor, pero con diferentes sustentaciones. Pero también puede ocurrir que B (o C) resista la pretensión y C (o B), en cambio, se allane. Como no podrá dictarse sentencia por separado $\mathrm{C}$, se convierte en litisconsorte de $\mathrm{A}$, a la espera del fallo.
} 


\section{Clases de intervención obligada}

Tradicionalmente la legislación procesal argentina mostró a la evicción como única manera de intervenir obligadamente de donde resulta que la garantía formal debía manejarse con los dispositivos de aquélla que analógicamente servían para la garantía simple. ${ }^{234}$ Luego, tal como lo recordamos en la reseña efectuada en los puntos 31 y 32 aparecen proyectos que bajo el concepto general de intervención obligada dan lugar al tratamiento conjunto de ambas garantías (proyectos Alcorta-Zeballos, Fernández, Enoch Aguiar-Cabral). En tanto, en la codificación se sigue el criterio de mantener un tratamiento específico de la evicción, pero al mismo tiempo establecer una regulación para los casos correspondientes a la garantía simple, al colegitimado, al tercero pretendiente y la nominatio auctoris. Así ocurre en el CPC de Jujuy (intervención obligada, art.79) y CPCC Santa Fe ( art.305 ) y también en el proyecto Reimundin y es el criterio que en definitiva sigue el CPCCN y las leyes que toman su modelo. En otros, por el contrario, se los considera de manera conjunta ${ }^{235}$. Sin embargo debe consignarse que a diferencia del proyecto Alcorta-Zeballos el resto de las propuestas y legislaciones no utilizan literalmente las denominaciones de garantía simple o formal.

Por encima de la diferenciación de tratamientos legislativos y de la distinción en garantías, advertimos que toda intervención obligada de

\footnotetext{
${ }^{234}$ Los antecedentes legislativos del instituto de la citación de evicción se encuentran en CPr.CC de Córdoba,(Ley 1419 de 1896), San Luis (ley 310 de 1906 ) y Santiago del Estero (Ley 1733 de 1941) ya derogados. Igualmente en la ley 2958 de 1905 de la Provincia de Buenos Aires. Proyecto Calvento.

${ }^{235}$ Códigos de La Rioja, Mendoza, Tierra el Fuego .
} 
terceros contiene determinados elementos. En efecto, en ellas, un tercero se incorpora coactivamente al juicio; en todas subyace una relación jurídica sustancial que vincula al tercero con una u otra de las partes; en todas, el tercero tiene opción de concurrir o no; en todas, la sentencia que se dicte tendrá trascendencia de cosa juzgada sobre aquélla relación. No obstante advertimos diferencias trascendentes: así, en la evicción, juega el sistema de sucesión sustancial en la titularidad de bienes, ausente en los demás casos; las modalidades de actuación del garante en la evicción, son diversas de las que se corresponden con el resto de las intervenciones en las que no cabe el fenómeno de la sustitución, aplicable en cambio en ciertos supuestos de la garantía formal; en la evicción se permite elegir al tercero a denunciar de una manera diversa que en los demás casos de intervención obligada .

Observada la regulación procesal puede verse que en el complejo formado por los arts.96 (94), 97(95) y 98(96) CPCCN están fijadas las bases del sistema de la intervención obligada, a saber: cuestión común y efecto de cosa juzgada, pivotes que están literalmente ausentes en el tratamiento de la evicción pero que le son plenamente aplicables como resulta del derecho sustancial. De ahí que pensemos que los artículos mencionados hacen a una parte general de la intervención obligada, referente a todos los supuestos que no tengan una regulación específica que la complemente o modifique. Decimos entonces que aquéllos dispositivos refieren la Intervención obligada genérica. En tanto, como caso especial, la ley procesal regula la Intervención obligada por evicción que se corresponde con la garantía de evicción de nuestro derecho de fondo (arts 2089 a 2117 Cód.Civil en su lineamientos generales; arts 1044 a 1050 $\mathrm{CCCN}$ ). Es claro que la especificidad del tratamiento legislativo no impide, ante la visible afinidad entre ambas figuras, que las disposiciones acerca 
de la evicción puedan, según el caso aplicarse por analogía a la intervención obligada genérica, ante la ceñida regulación que esta última muestra en el CPCCN.

Junto a las dos vertientes de intervención obligada que mencionamos, encontramos una tercera: es la significada por el instituto del aseguramiento, regulado por ley especial (ley 17.418). Tenemos así, la Intervención obligada por aseguramiento (garantía formal aseguradora) que mantiene la esencia común con las anteriores, si bien rediseñada por la regulación propia, con objetos específicos y modalidades exclusivas que la muestran fuera de los sistemas del CPCCN y del CCCN.

No obstante no ser el objeto de este trabajo, limitado a la intervención obligada genérica, nos parece oportuno considerar muy brevemente la intervención por aseguramiento y la garantía de evicción como instituto de derecho sustancial-procesal, manera de mostrar sus particularidades.

\section{Intervención obligada por aseguramiento}

a) Normativa. En materia de seguros y con relación al tema que hace a esta obra, tendremos que tener en cuenta la legislación sustancial conformada por la ley 17.418, en especial las disposiciones referidas al seguro de responsabilidad civil. Así, el art. 118 de la ley de seguros en su segunda parte expresa, que "el damnificado puede citar en garantía al asegurador hasta que se reciba la causa a prueba....". En tal caso debe interponer la demanda ante el juez del lugar del hecho o del domicilio del asegurador". La tercera parte señala que "La sentencia hará cosa juzgada respecto del asegurador y será ejecutable contra él en la medida del 
seguro". La cuarta parte, dice que "también el asegurado puede citar en garantía al asegurador en el mismo plazo y con idénticos efectos". Los dispositivos transcriptos abarcan y se refieren, por un lado, a las relaciones demandado-asegurador propio y demandante-asegurador propio y por otro a las correspondientes a demandante-asegurador del causante del daño. Pasaremos a reseñarlas.

b) Relación demandado con asegurador propio. A diferencia de la expresión "citación en garantía" de la segunda parte del art.118 ley de seguros, en la que se la debe tomar como equivalente a demanda contra el asegurador del causante, la similar que encontramos en la última parte de dicho artículo, puede ser entendida bien como demanda del citante contra el citado -y a la vez dentro de esta última tesitura, como demanda con contenido de pretensión de condena, o meramente declarativa-, o como litisdenuntiatio a la manera del art.96(94) CPCCN si bien con tiempos y efectos propios .

Si descartamos una acción del condena del tipo de las de garantía italiana por no hacer a nuestra función jurisdiccional (ver punto 3) no podemos admitir que en cambio resulte viable planteada por el asegurado demandado contra su propio asegurador. Una demanda con pretensión solo declarativa tendida entre los mismos sujetos, no tendría sentido práctico: al pronunciamiento respectivo le faltaría el "plus" de condena; para solamente obtenerlo, habría que demandar nuevamente. Queda como única posibilidad viable la de asignarle el sentido procesal: citación como pura denuncia de litis en su real significado, que, como luego veremos, excluye toda modalidad de demanda.

A partir de entonces la ley crea un sistema de derecho sustancial que tiene a la denuncia de litis como presupuesto, pero que le agrega efectos 
connaturales con la relación de seguros. Tal como ocurre en todos los casos de citación, concurra o no el convocado, la sentencia que se dicte lo involucrará al hacer cosa juzgada sobre la cuestión común, es decir: la responsabilidad del asegurado en el evento dañoso. Declarada la culpabilidad del asegurado, el asegurador debe cumplir con su obligación básica: mantenerlo indemne por cuanto deba a un tercero sin que sea necesaria una sentencia que lo especifique (art.109, ley 17.418) incluido gastos y costas (art.109 ley 17.418).

La sola citación y una respuesta del asegurador acudiendo en defensa del asegurado- situación que importa aceptar la vigencia de la obligación aseguradora - hace jugar el sistema de la demanda implícita (ver punto $\mathbf{1 0 0}$ c) colocando al citado en el papel de demandado frente al actor.

También puede darse que el asegurado niegue su obligación aseguradora, para lo cual deberá plantear una pretensión incidental declarativa negativa contra el pretendido asegurado de cuya suerte dependerá que tenga que responder por el seguro si resultare derrotado al respecto.

En caso de vigencia del seguro sobreviene otro efecto: el de ejecutabilidad. En la relación que venimos considerando, aseguradoasegurador propio, la cuarta parte del art.118 otorga al citante la misma posibilidad de ejecución de la que goza el damnificado: así, si tuvo que afrontar la condena de su propio peculio podrá resarcirse ejecutando al asegurador-sometido al efecto de cosa juzgada y titular pasivo de una obligación aseguradora vigente- por el monto desembolsado.(art.768 incs.1 y 2 Cód.Civil).

c) Relación damnificado con asegurador propio. Se rige por las mismas soluciones y temáticas del caso demandado-asegurador propio, 
salvo que su ejecución contra el asegurador solo podrá darse por el importe de las costas que tuvo que afrontar en caso de haber sido derrotado.

d) Relación damnificado con asegurador del responsable. En la relación tratada, el concepto de "citación" debe entenderse como demanda, de modo que la ley posibilita que el damnificado demande al asegurador del responsable el resarcimiento del perjuicio sufrido a condición de que cumpla con lo dispuesto por la segunda parte del art.118 de la ley 17.418. Al respecto, predomina la idea de que debe acumular la demanda a la que sigue contra el culpable del daño. Demandado formalmente o autocolocado en el rol de demandado, la sentencia que declare la responsabilidad del accionado, involucra la condena al asegurador y la posibilidad de ser ejecutado por el demandante en caso de incumplimiento del fallo. Asimismo otorga al demandado que tuvo que afrontar por sí el cumplimiento del fallo, el poder subrogatorio que más arriba señaláramos.

e) La dirección del proceso. Cuando el asegurado es demandado, como natural consecuencia de su condición de tal, debe asumir la defensa correspondiente .Sin embargo, interfiere en el tema el caso del asegurador citado por su asegurado-actor o demandado- que hace jugar el instituto de la asunción de la dirección del proceso.

Es obvio que el asegurador ha de tener un interés similar o mayor que el del asegurado en obtener el triunfo en una confrontación con la contraparte; por ende se le ha de conceder la posibilidad de cubrirse de cualquier actuación deficiente por parte del garantizado, quien a la vez tiene el deber de facilitarle la obtención de tal objetivo. De ahí que se 
admita que tiene el derecho ${ }^{236}$ de ejercer la "dirección exclusiva de la causa" extremo que aparece mencionado escuetamente en la parte final del art.110 a) sin más explicación.

La "dirección de la causa" importa para el asegurador, la posibilidad de excluir al asegurado del manejo intelectual de su defensa en juicio, privándole por ende y al respecto, de su libre albedrio y de la facultad de gestión propia. Ello puede ocurrir mediante la formulación extrajudicial de directivas $\mathrm{u}$ orientaciones que, de acuerdo a la relación sustancial, el asegurado deberá respetar aun cuando siga ejercitando materialmente la defensa de su derecho. En realidad esa solución no tiene trascendencia en lo procesal en cuanto a sustitución o intervención tercerista; pero la dirección referida puede traducirse en la asunción de defensa, que ocurrirá cuando el asegurador opere materialmente como defensor del asegurado desplazándolo del ejercicio de su propia defensa, al tiempo que comprometiéndolo con la actuación que lleve a cabo pues sus actos y postulaciones serán vinculantes para ese sujeto.

La actuación del asegurador en tal función, excluye la que de modo paralelo pudiese intentar el asegurado, de modo que el actor no tendrá que enfrentarse a un doble juego de actos procesales. Pero, en tal condición y sin perjuicio de su derecho de defensa a título propio y de sus limitaciones (por ejemplo, art.118, segunda parte in fine, ley 17.418) el asegurador estará ceñido frente al actor, a las posibilidades defensivas del asegurado.

\footnotetext{
${ }^{236} \mathrm{Si}$ bien esa es la idea predominante no se la acepta sin discusión. Nos inclinamos por apoyarla ya que la ley 17.418 deja en manos del asegurador asumir tal dirección o dejarla en manos del asegurado (art.110 a) in fine ) derecho que le permite desplazar al propio asegurado en lo procesal y hasta coartarle el poder de disponer de su obligación sustancial (art.116 segunda parte ley 17418)
} 
La asunción material de la defensa por parte del asegurador es una solución teóricamente admisible, pero en la práctica se aplica un método al que llamamos de "control interpósito" derivado de una cláusula específica inserta en la póliza, por la que el asegurado se compromete a designar como representante y patrocinio letrado a los indicados por la aseguradora que de tal manera que se autogarantiza el ejercicio de la dirección del proceso, pero sin materializar su presencia ya que los profesionales actuantes lo harán por designación y mandato del propio asegurado.

\section{La evicción}

a) La evicción. Instituto sustancial en el Código Civil. La garantía de evicción opera de pleno derecho (sin necesidad de acuerdo que la establezca -art.2097 Cód.Civil- y no obstante convención en contrario -arts 2099 y 2100 Cód.Civil.-), sobre el enajenante, cedente o vendedor que de cualquier forma transmitió bienes a título oneroso (art.2089 Cód Civil) o transmitió o dividió con otros -a igual título- bienes hipotecados, o los dividió con otros si el adquirente o copartícipe no pudo conservarlos sin pagar al acreedor hipotecario (art.2090 Cód. Civil). Corresponderá efectivizar tal garantía, cuando el adquirente sea privado o turbado en la propiedad, posesión o goce del derecho transmitido por causas anteriores o contemporáneas a la adquisición de buena fe ${ }^{237}$. También puede aplicarse,

\footnotetext{
237 "es la obligación impuesta a todo el que transmite un derecho, sirviéndose de un título de carácter oneroso, de responder por las consecuencias de una eventual privación o turbación en el ejercicio del derecho transmitido, originada en una causa anterior (o concomitante) al acto de transmisión y que haya sido desconocida por el adquirente" Wayar Ernesto Clemente, La garantía de evicción, ED104-859
} 
si con posterioridad a la enajenación, el transmitente lleva a cabo actos que afecten el valor y alcance del derecho trasmitido ${ }^{238}$. Al respecto el Cód Civil define la evicción ${ }^{239}$ así como por su lado lo hace el $\mathrm{CCCN}^{240}$.

En lo referente a su origen, es menester tener en cuenta que si bien la evicción, como garantía global, precisa como presupuesto de una relación contractual (compraventa, donación onerosa y en otras situaciones-art.2146 Cód.Civil-,cesión etc.) su existencia es de fuente normativa; proviene entonces, no del contrato en sí, en el que puede o no estar establecida expresamente, sino de la ley que la impone independientemente del pacto explícito.

Para generar evicción, el litigio deberá ser provocado por turbaciones jurídicas, las que deben consistir en "toda pretensión, excepciones o defensas deducidas en juicio por un tercero y que de prosperar

\footnotetext{
${ }^{238}$ Así lo estableció la Corte Suprema en fallo de fecha 3/8/42 el caso Miller Guillermo c/Pcia de Mendoza,LL t.28 p.540) litigio en el cual, la demandada luego de vender al actor una determinada superficie, enajenó a otra persona, parte del mismo predio,

239 Art.2091:'Habrá evicción, en virtud de sentencia y por causa anterior o contemporánea a la adquisición, si el adquirente por título oneroso fe privado en todo, o en parte del derecho que adquirió, o sufriese una turbación de derecho en la propiedad, goce o posesión de la cosa. Pero no habrá lugar a la garantía, ni en razón de las turbaciones de hecho, ni aun en razón de las turbaciones de derecho ,procedentes de la ley, o establecidas de una manera aparente, por el hecho del hombre, o de pretensiones formadas en virtud de un derecho real o personal de goce, cuya existencia era conocida al tiempo de la enajenación"

${ }^{240}$ Art.1044.Contenido de la responsabilidad por evicción. La responsabilidad por evicción asegura la existencia y legitimidad del derecho transmitido y se extiende a) toda turbación de derecho, total o parcial, que recae sobre el bien, por causa anterior o contemporánea a la adquisición. b) los reclamos de terceros fundados en derechos resultantes de la propiedad intelectual o industrial, excepto si el enajenante se ajustó a especificaciones suministradas por el adquirente. c) las turbaciones de hecho causadas por el transmitente.
} 
determinaría la pérdida total o parcial del derecho adquirido" ${ }^{241}$. En cambio, la garantía no es debida ante turbaciones de hecho (art.2091 segunda parte Cód.Civil); así como tampoco por "turbaciones de derecho producidas por la ley o establecidas de una manera aparente por hecho del hombre, o de pretensiones formadas en virtud de un derecho real o personal de goce, cuya existencia era conocida al tiempo de la enajenación" (art.2091 Cód.Civil) salvo las comprendidas en el art. 2094 Cód. Civil ${ }^{242}$. La normativa determina quienes están legitimados para denunciar la litis existente y requerir la citación ${ }^{\mathbf{2 4 3}}$.

Señalada la legitimación necesaria, debe ponerse de resalto que tanto en la ley civil como en las procesales y en la casuística jurisprudencial puede verse con mayor nitidez y frecuencia el caso de la citación por la parte demandada. No obstante lo dicho, vemos que el garantizado puede precisar poner en juego como actor el valor del derecho transmitido, sea

\footnotetext{
${ }^{241}$ Borda Guillermo A.Tratado de Derecho Civil Argentino. Contratos T.I, pg.122. Novena edición. La Ley Buenos Aires.2009
}

242 "Art.2094 "Habrá lugar a la evicción ,cuando un acto del Poder Legislativo, o del Poder Ejecutivo privase al adquirente en virtud de un derecho preexistente, pero no habrá lugar a la evicción, si el acto que trae la privación del derecho no fuese fundado sobre un derecho preexistente, o sobre una prohibición anterior, que pertenece al soberano declarar, o hacer respetar"

${ }^{243}$ Están legitimados para citar y hacer jugar a su favor la garantía de evicción las partes originarias de un proceso; así resulta del art.2108 Cód.Civil en cuanto en su primera parte se refiere al citante demandado y en su párrafo final al citante demandante o por demandar. Es obvio que como el derecho a convocar pertenece exclusivamente al garantizado pues hace a su interés, su contrario no puede sino citar al garante propio y no al de su oponente ( CS Fallos 20:123, citado por Podetti (Podetti J.Ramiro. Tratado de la tercería,pg.453. Segunda edición actualizada por Víctor A. Guerrero Leconte. Ediar. Buenos Aires. 1971). Fuera de las partes originarias la citación puede producirse por los propios citados-cualquiera sea la posición procesal de aquéllas- que lo hubiese llamado a juicio a fin de salvaguardar su exclusivo derecho de garantía. Esa solución es recogida por el art 112(110) CPCCN. 
porque sustente o quiera sustentar una pretensión (por ejemplo una reivindicación, un reclamo para efectivizar su derecho de usufructo, el ejercicio de una servidumbre activa, la improcedencia y cese de una servidumbre pasiva) o una acción declarativa para prevenir el pleito en el que se puede jugar su derecho.

b) Alcance. Evicción y saneamiento. Corresponde establecer el verdadero contenido de la garantía de evicción, sobre todo cuando se observa que doctrina y jurisprudencia para denominarla, manejan los términos evicción y saneamiento y este último aparece referido en el Cód. Civil (art. 2109) y en algunos códigos procesales civiles, tales los de Jujuy y Santa Fe.Véase en el apartado C, el CCCN.

La doctrina se divide entendiendo algunos autores que se trata de la misma garantía ${ }^{244}$, pero otras opiniones sostienen que la evicción hace a la pérdida del bien mientras que el saneamiento se corresponde con la indemnización consiguiente. En una tercera postura se entiende que son garantías diferentes y que la primera hace a asumir la defensa ante una turbación significada por una demanda o la necesidad de contestarla, en tanto que la segunda se corresponde con una sentencia adversa al adquirente que obliga al enajenante a resarcirlo por la pérdida que tenga

\footnotetext{
${ }^{244}$ Salvat Raymundo M. Tratado de Derecho Civil Argentino, Fuente de las Obligaciones. Actualizada por Arturo Acuña Anzorena, T.III, pg 364, nota c. TEA, Segunda Edición. Buenos Aires.1954. Ripert George-Boulanger Jean, Tratado de Derecho Civil según el Tratado de Planiol, T.VIII, Contratos Civiles, La Ley, Buenos Aires.1965.2. Según el Doctor Tobal (ver su voto en la causa Green Francisco c/Velazco Palacios y Cía, Cám.Civ.1 ${ }^{a}$ Capital 14/11/41, LL t.24 pg.890 no se trata de cosas distintas sino de diversas etapas del mismo proceso, pero expresa "Así sanear viene a tener un significado presente y futuro, desde que no solo importa la transmisión libre de cargas, sino la obligación de subsanar todo defecto que pudiera hacer a la no perfección del título".
} 
que soportar frente al tercero ${ }^{245}$. Colombo recuerda la presencia del art.1414 del Cód. Civil que, para la compraventa, impone al vendedor como primer deber, sanear y luego responder por la evicción; sanear sería un concepto de mayor amplitud que la evicción ${ }^{246}$.

Nosotros pensamos que si nos atenemos al significado literal y el valor ontológico de la palabra saneamiento, debemos concluir en que la evicción es una garantía única que se manifiesta en tres vertientes. La primera es la "citación de defensa", para cuyo cumplimiento a través de la "asunción de la defensa" es necesaria la existencia de un proceso abierto (o por abrir, según alguna legislación procesal, (Ver nota 1).Es claro que se trata de un objetivo buscado por el citante ya que nadie en mejores condiciones para defender el derecho en juego que quien fuera su titular y que como tal, se supone que lo conoce a fondo. Sin embargo ello está dependiendo del caso concreto pues la participación efectiva del tercero puede resultar indiferente o de un interés menor; por ejemplo, puede ocurrir lo primero si de ello depende la posibilidad de sanear, o si la mayor aptitud económica del tercero hacen deseable su presencia en el juicio; pero

${ }^{245}$ CN Apelaciones Civil Capital, Sala B, Barzi Hnos SRL c/Petrucci José A.,JA 1957III-184. Voto del Doctor Barraquero; "la citación de evicción se hace cuando se reclama la propiedad, goce o posesión al adquirente, y la de saneamiento, cuando haya sido vencido en juicio". Wayar Ernesto Clemente, trabajo citado en nota ; Fernández Maza Guadalupe, La citación de evicción, en Intervención de terceros y tercerías, Director Osvaldo Alfredo Gozaini, pg.470/71. Rubinzal-Culzoni. Editores. Santa Fe -Buenos Aires, 2011.

${ }^{246}$ Colombo Carlos J. Evicción, Litis denuntiatio y laudatio actoris, en Revista de Derecho Procesal, Dirección Hugo Alsina, Año II, Primer trimestre 1944,nº 1.Ediar Buenos Aires, pg 29). 
también puede darse que el citante se encuentre munido de todos los elementos defensivos ${ }^{247}$ y no precise de la concurrencia del enajenante.

Si partimos de entender que se sanea lo afectado o enfermo siempre que se puede corregir o curar, en tanto que se indemniza lo perdido para tratar de ocupar su lugar, la segunda vertiente consiste, -ante la citación y siempre que ello sea posible- en llevar a cabo las tareas necesarias para remontar los defectos que pudiera tener el título de manera de tornar abstracto el reclamo del tercero o bien de asumirlo cubriendo económicamente lo reclamado, como modos de evitar el desmedro patrimonial del garantizado, pues es de presumir que para el mismo, ha de ser más valioso conservar el derecho o las cosas inherentes, que no verse compensado por su pérdida ${ }^{248}$.

La tercera vertiente, se dará cuando se efectivice, como resultado de la sentencia, la indemnización por la pérdida o afectación del derecho o la cosa transmitida.

c) El Código Civil y Comercial de la Nación. Determina separadamente la existencia de la obligación de saneamiento y la de evicción. La primera existe de pleno derecho art.1036 CCCN), pero la convención sobre su disminución o supresión son de interpretación

\footnotetext{
${ }^{247}$ Recordar que el juicio puede prepararse pidiendo, la documentación obrante en manos del enajenante(art.323 inc.4 CPCCN quien vaya a demandar o vaya a ser demandado

248 "La garantía de evicción no solamente se refiere a la cosa misma y al derecho de dominio sobre ella, sino a la perfección de los títulos que se han transmitido, a menos que se hubiese estipulado que se adquirió con títulos defectuosos o que se los aceptaba en su actual condición"(Lafaille Héctor, Curso de contratos compilado por Isauro P. Arguello (h) y Pedro Frutos. T. II. Contratos bilaterales, pg.471. Talleres Gráficos Ariel. Buenos Aires. 1928).
} 
restrictiva (art.1037 CCCN) y en algunos casos se las tiene por no convenidas(art.1038 CCCN); comprende la garantía de evicción y por vicios ocultos (art.1034 CCCN); se impone al transmitente a título oneroso, a quien ha dividido bienes con otro y a sus antecesores en transferencias a título oneroso (art.1033 CCCN). La evicción garantiza la existencia y legitimidad del derecho transmitido, las turbaciones del derecho anteriores o coetáneas con la transmisión, las turbaciones de hechos provocadas por el transmitente y los reclamos de terceros sobre la propiedad intelectual transmitida (art.1044 CCCN); también los gastos de defensa (art.1047 $\mathrm{CCCN}$ ). La obligación comprende (art.1039 CCCN): el saneamiento de títulos o la subsanación de los vicios; el reclamo de un bien equivalente siendo fungibles; la resolución del contrato, salvo prescripción liberatoriaya que en ese caso se extingue la obligación o defectos subsanables (arts 1050 y $1057 \mathrm{CCCN}$ ).De haber mediado enajenaciones sucesivas la responsabilidad por saneamiento ,habrá obligación concurrente (art.1042 $\mathrm{CCCN}$ ).El garante no puede alegar su ignorancia o error salvo convención en contrario (art.1043 CCCN).

La garantía cesa si la citación al garante no se produce en los momentos marcados por la ley procesal, por defectos en la defensa y recursos, sometimiento a laudo (arts. $1048 \mathrm{CCCN}$ ).

Entendemos que la garantía de saneamiento juega independientemente de la existencia de una turbación del derecho transmitido por parte de terceros o del propio transmitente; pero si esa turbación se produce, entra a jugar la garantía de evicción que a la vez comprende el alcance del saneamiento. De tal manera y con el enfoque que hace al objeto de este trabajo, nos parece que en caso de reclamos judiciales, el sistema del Código Civil no sufre modificaciones: se debe el 
saneamiento como posibilidad conservativa del derecho y la evicción como posibilidad compensatoria ante su pérdida del derecho. La defensa en juicio se debe en todo supuesto.

d) La evicción. Instituto procesal. El CPCCN regula el instituto de la intervención obligada por evicción en sus artículos 107(105) a $112(110)^{\mathbf{2 4 9}}$.

${ }^{249}$ Art.107. Oportunidad. Tanto el actor como el demandado podrán pedir la citación de evicción: el primero, al deducir la demanda; el segundo, dentro del plazo para oponer excepciones previas en el juicio ordinario, o dentro del fijado para la contestación de la demanda, en los demás procesos

La resolución se dictará sin sustanciación previa. Sólo se hará lugar a la citación si fuere manifiestamente procedente.

La denegatoria será recurrible en efecto devolutivo.

Art.108 .Notificación. El citado será notificado en la misma forma y plazo establecido para el demandado. No podrá invocar la improcedencia de la citación, debiendo limitarse a asumir o no la defensa. Si no la ejerciere, su responsabilidad se establecerá en el juicio que corresponda".

Art. 109 "Efectos. La citación solicitada oportunamente suspenderá el curso del proceso durante el plazo que el juez fijare. Será carga del citante activar las diligencias necesarias para el conocimiento del citado. El plazo para oponer excepciones previas y la sustanciación de éstas no quedarán suspendidos."

Art.110. Abstención y tardanza del citado. Si el citado no compareciere o habiendo comparecido se resistiere a asumir la defensa, el juicio proseguirá con quien pidió la citación, salvo los derechos de éste contra aquél.

Durante la sustanciación del juicio, las dos partes podrán proseguir las diligencias para obtener la comparecencia del citado. Si éste se presentare, tomará la causa en el estado en que se encuentre. En la contestación podrá invocar las excepciones que no hubiesen sido opuestas como previas." 
Como resulta del art.108(106) CPCCN, el garante de evicción tiene ante la denuncia de litis, la posibilidad de concurrir al juicio o abstenerse de hacerlo, salvo presentarse al solo efecto de manifestar que no asumirá la defensa (art.110(108) CPCCN), cosa que por sí misma no significa negar su condición de garante. Con la concurrencia, tal como se dijo en el punto $\mathbf{1 0}$, el garante de evicción puede llegar a obrar como sustituto procesal solo si se produce la extromisión del garantizado con la conformidad expresa del adversario $^{\mathbf{2 5 0}}$; de lo contrario su función será de coadyuvación propia, pero no por subordinación sino por concordancia. Téngase en cuenta que el CPCCN, en su art.111(109), regula un caso de participación litisconsorcial de ambos sujetos, con actuación material separada o conjunta pero siempre con la presencia del citante. (Conf.art.1046, parte final CCCN) presencia demostrativa de que éste no delegó su defensa. Tal participación no tiene valor sustituyente sino coadyuvante ya que no libera a la parte originaria de su condición de tal, de sus deberes como parte ante la contraria, ni de los efectos de la cosa juzgada. Lo afirmado es perfectamente compatible con la condición litisconsorcial que le atribuye el art.111(109) CPCCN. De esa manera, si el garante opera inicialmente junto con el garantizado, será su

Art.111. Defensa por el citado. Si el citado asumiere la defensa podrá obrar conjunta o separadamente con la parte que solicitó la citación, en el carácter de litisconsorte.

Art.112 Citación de otros causantes. Si el citado pretendiese, a su vez, citar a su causante, podrá hacerlo en los primeros cinco días de haber sido notificado, sin perjuicio de la carga de seguir el proceso por sí. En las mismas condiciones, cada uno de los causantes podrá requerir la citación de su respectivo antecesor.

Será admisible el pedido simultáneo de dos o más causantes.

Será ineficaz la citación que se hiciere sin la antelación necesaria para que el citado pueda comparecer antes de la sentencia de primera instancia."

${ }^{250}$ Podetti Ramiro J. Obra citada, pg.465; Palacio Lino E. Obra citada, pg.221. 
litisconsorte ya que la ley le otorga esa categoría de actuación procesal como coadyuvante calificado. Es claro que no será la misma calidad litisconsorcial que deriva de la titularidad de la relación jurídica sustancial en juego en cuya virtud pudo demandar o ser demandado, ya que el garante de evicción no integra aquélla, ni tiene acción por sí contra el contrincante del garantizado ni ese oponente la tiene en su contra.Pese a ello, la ley le concede facultades procesales litisconsorciales en homenaje a su calidad de causante del derecho transmitido, diferenciándolo así de un coadyuvante simple y evitándole que como tal, pudiese quedar inerme frente al garantizado si le estuviese subordinado.

$\mathrm{Si}$, por el contrario, el garante obra como sustituto no será sino, precisamente, sustituto; es decir que tomará la defensa en juicio del derecho sustancial de pertenencia del garantizado, reemplazándolo en esa tarea, sin que éste quede definitivamente privado de poder hacerlo por sí cuando lo considere adecuado, momento en que el ex sustituto y el ex sustituido pasarán a operar litisconsorcialmente.

Ahora bien: no obstante no ser tercero adhesivo ni coadyuvante subordinado, el garante de evicción, si ingresa en el proceso, no tiene otra posibilidad que hacerlo enfrentando a la contraparte, papel que podrá llevar a cabo coincidiendo o discrepando con el garantizado en las defensas que oponga pero siempre en línea con el objetivo de buscar la derrota del oponente. Así le obliga la relación sustancial de garantía.

Sustituto o litisconsorte, el garante no tiene poder de disposición sobre el derecho sustancial que sigue en total pertenencia del garantizado. Los actos de disposición que éste pudiera hacer en esas condiciones, servirán para sustentar en su momento, la exceptio mali defensa. 


\title{
CAPITULO CUARTO
}

\section{LA INTERVENCIÓN OBLIGADA GENERICA}

\author{
SECCION PRIMERA
}

ALCANCE DE LA INERVENCIÓN OBLIGADA GENÉRICA

40. Objetivos altruistas, ordenatorios e instructorios

Siendo claros tanto la función procesal del interviniente obligada de tercero, como el objetivo buscado por el instituto de tal institución, no será posible computatr al efecto los casos en los que un sujeto es incorporado al litigio con finalidades distintas de las que hacen al sistema de los arts 96(94),97(95) y 98(96) CPCCN. Así, el aviso de la existencia de un pleito formulado como gentileza y sin trascendencia sobre la relación citante citado, puede llevarse a cabo extrajudicialmente pues no configura un 
interés protegible que justifique su práctica judicial- y menos por la via de los dispositivos mencionados- ya que no generará necesariamente ninguna consecuencia de cosa juzgada ni se formulará sobre la base de la existencia de una cuestión común a debatir. En tal sentido coincidimos con Wach (Ver punto 17) sobre la condición egoísta de la denuncia de litis.

Lo dicho no quita que, en un campo ajeno al art.96(94) CPCCN, pueda producirse la citación como manera de colaborar en el mantenimiento del principio de buena fe y moralidad procesal sin que se requiera al efecto un interés específico de autoproducir una ventaja para el citante, sino el de evitar situaciones de fraude procesal o que habiliten el riesgo de que se produzcan. Así lo establecen diversas legislaciones ${ }^{251}$. Pensamos que la falta de una disposición similar en la ley procesal nacional no impide que para hacer jugar el principio de buena fe procesal y el deber judicial establecido al respecto, (art.34 inc.5.punto 4 CPCCN) los magistrados ordenen el llamamiento o lo promuevan las partes ${ }^{\mathbf{2 5 2}}$.

Tampoco es posible confundir el tema de la intervención obligada con el de las facultades instructorias oficiosas. Estas aparecen especificadas en la ley nacional ( por ejemplo, el juez puede llamar por sí a testimoniar personas ajenas siempre que aparezcan mencionadas en escritos constitutivos o resulten designadas en otras pruebas-art $\left.452 \mathrm{CPCCN}_{-}\right)^{\mathbf{2 5 3}} \mathrm{y}$

\footnotetext{
${ }^{251}$ Por ejemplo, coexistiendo con la citación oficiosa, en casos de fraude o colusiónart.105 CPCC Tierra del Fuego; art 96 CPCC San Juan; Art.54 CGP Uruguay-art.64 Código Modelo para Iberoamérica-; o solamente oficiosa, arts.58 CPC y 72 CGP Colombia y art.106 CPC Perú.

${ }^{252}$ De Gregorio Lavié Julio A. Código Procesal Civil y Comercial de la Nación. Comentado. Doctrina. Jurisprudencia, pg.266. Ediar. Buenos Aires. 1985.

${ }^{253}$ Con mayor amplitud es facultad que otorga a los jueces el art.22 del Proyecto Lascano y el art.46 inc.5 CPC Mendoza.
} 
empalman con los principios inquisitivo y dispositivo ; pero es de advertir las facultades referidas hacen a la prueba de los hechos alegados en el conflicto presente y no a la trascendencia de la cosa juzgada sobre conflictos futuros ${ }^{254}$.

Se ha sostenido que para un mejor proveer, o como dice Calamandrei, refiriéndose a la ley italiana, por razones de economía procesal y para evitar pronunciamientos contradictorios, resulta posible convocar oficiosamente a terceros. Esa idea fue aceptada por doctrina y jurisprudencia aun antes de la sanción del CPCCN (ver al respecto punto 30), pero también aquí es necesario diferenciar tales objetivos de los que hacen a los tenidos en cuenta por el art.96(94) CPCCN. La magistratura tiene el deber-facultad de procurar la economía procesal, preservar nulidades (art.34 inc. $5^{\circ}$, puntos 2 y 5 CPCCN ) y evitar sentencias contradictorias (arts 190(189) y 191(190) CPCCN) pero tales extremos no hacen al del sistema de la intervención obligada que presupone la inexistencia de tales vicios procesales. Ver sin embargo en el punto $\mathbf{6 5 c}$, el tema de las intervenciones de terceros en materia de preservación del medio ambiente y su manejo por la Corte Suprema.

\section{Campo de aplicación según la Exposición de motivos}

\footnotetext{
${ }^{254}$ Ver en el punto 18, la crítica de Calamandrei a la posición de Chiovenda basada en la redacción del art.106 CPC italiano que permite la citación oficiosa en igualdad de situación con la promovida por la parte en todos los casos de existencia de cuestión común.
} 
a) Introducción. A diferencia de las leyes procesales de Alemania, Brasil, Colombia, Perú y Venezuela que permiten establecer un buen grado de correspondencia entre el derecho positivo y los diversos supuestos considerados por los autores, el CPCCN no impone ni tiene tal correlación de modo que no determina los casos que quedan comprendidos en la que llamamos intervención genérica, si bien proporciona tratamiento diferenciado a la evicción, en tanto la ley 17.418 hace lo propio con el aseguramiento.

Por el contrario, en apartamiento del sistema descripto de la ZPO y aproximándose a un modo lato de expresar el fenómeno tal como el adoptando por el art.106 del CPC italiano al referirse a la "comunidad de causa", el CPCCN toma el concepto de "controversia común" pero sin referir a la acción de garantía separándola de aquella comunidad tal como hace la ley peninsular. Con ello nos proporciona una denominación de un objeto pero no nos dice qué es y qué alcance tiene. Como luego veremos ,hay controversias comunes relativas a distintos fines y no solo las que pueden hacer a la intervención obligada. De ahí que necesitemos primero establecer el campo ,las fronteras exactas de esa figura para luego ver si dentro de las mismas se encuentra la controversia común que sirva de presupuesto para la intervención obligada. A tal fin, en virtud de esa característica de nuestra codificación, será menester analizar los elementos de juicio que nos proporciona la Exposición de Motivos del CPCCN acompañada al proyecto de ley que diera lugar a la sanción de la ley 17.454. En dicha pieza la evicción es mencionada separándola del resto de los casos comprendidos en el sistema de la intervención obligada que concebimos como genérica. Dice respecto al campo atribuible a esta última, que "La fórmula utilizada para conceptualizar la figura de la intervención obligada (art.94) comprende aquellas hipótesis en las cuales la 
parte eventualmente vencida, tenga una acción regresiva contra el tercero, o medie conexidad entre la relación controvertida en el proceso y otra relación existente entre el tercero y alguna de las partes originarias".

La exposición, muestra así a la conexidad como un supuesto distinto de la acción regresiva, configurado cuando aparece un vínculo entre la relación sustancial debatida con otro tendido entre alguno de las partes y un tercero. Igual que en la acción regresiva- que por otra parte muestra un claro ejemplo de conexidad- pero sin el objetivo resarcitorio que va ínsito en dicha acción

b).Reflexiones sobre la conexidad.Decimos desde ya que a los fines del art.96(94) CPCCN y su sistema, no puede computarse la conexidad por la conexidad misma, sino en función de un fin que justifique la citación por la existencia de algún conflicto presente o la posibilidad de uno futuro que afecte la situación del citante. Solamente dentro de ese contexto es donde pueda tener significación el concepto de "cuestión común" a debatir ("controversia común") entre las partes originarias y el tercero asi como el efecto extensivo de cosa juzgada que establece el art.98 (96)CPCCN. De lo contrario, es obvio que no habrá controversia común al no darse posibilidad de enfrentamiento. De allí que no podemos compartir la idea de Calamandrei acerca de la viabilidad de llamar en causa sin tener un derecho contra el tercero-o del tercero contra el citante-pues si no lo hubiere ,no habría posibilidad de generar la discusión común de la que habla nuestra ley, ni la comunidad de causa del derecho italiano. El mismo autor cuando nos dice que la citación entre coacreedores que no tienen cosa que demandarse apunta a la extensión de la cosa juzgada, nos indica la existencia de un derecho de liberación en cabeza del citante a expensas del citado. 
Precisamente y según lo expuesto renglones más arriba, no podemos aceptar que entren en el régimen de la intervención obligada los casos de intervención del colegitimado (denuncia de litis del coacreedor demandante al coacreedor no demandante, o bien denuncia de litis del codeudor demandado al codeudor no demandado) sin que pueda existir entre ellos (coacreedores con coacreedores y codeudores con codeudores) prestaciones que reclamar. Así veremos en el punto 52c, como en tales casos subyacen acciones regresivas.

\section{Casos de aplicación según la doctrina}

Según la doctrina nacional, que sigue la categorización formulada por las doctrinas europeas y que ya son clásicas (ver al respecto los puntos $\mathbf{1 7}$ y 18), la intervención obligada de terceros es aplicable a diversas situaciones derivadas de un litigio en el que se debate una cuestión que puede tener incidencia sobre el ajeno al pleito. A título de ejemplo, tomamos la de algunos autores. Así,según Palacio, comprende los siguientes supuestos, 1) nominatio auctoris 2) citación del colegitimado para intervenir, 3) citación del tercero pretendiente y 4)citación del sujeto pasivo de una eventual pretensión regresiva, ámbito comprensivo de la garantía de evicción ${ }^{255}$; o bien 1) litis denuntiatio, para el caso de acciones de regreso 2) laudatio o nominatio auctoris, 3) llamamiento del tercero pretendiente 4) llamamiento en garantía (citación del asegurador por el asegurado, citación de evicción) ${ }^{\mathbf{2 5 6}}$. Podetti tampoco muestra diferencias

\footnotetext{
${ }^{255}$ Palacio Lino E.Derecho... citadaT.III,pgs 214 y 215

${ }^{256}$ Fassi Santiago-Yañez César D.Obra citada,T.1, pgs.524 y 525.
} 
sustanciales en los casos que considera, si bien los computa y ajusta a su idea de la incidencia del interés subyacente. Para Martínez, las categorías posibles son la litisdenuntiatio en sentido estricto y la litisdenunciatio en sentido amplio que permite alcanzar a la citación del colegitimado, la denuncia o el llamamiento al tercero pretendiente, la indicación del poseedor mediato (laudatio o nominatio auctoris), la citación de evicción o saneamiento y la citación al asegurador (ley 17.418)

Falcón considera que los supuestos de intervención coactiva son :1) denuncia o comunicación al legitimado para intervenir 2) citación al tercero pretendiente (ejemplo, art.757 inc.4 Cód.Civil) ; 3)citación por controversia común, caso en el que se incluyen diversos supuestos a saber: comunidad de obligaciones (arts 712 y 716 Cód.Civil), existencia de contrato (arts 1646 y 2029 Cód.Civil), relaciones de dependencia o guarda de la cosa (art 1113,1125 Cód.Civil); casos especiales (por ejemplo, impugnación de paternidad y filiación, nominatio auctoris ${ }^{258}$ ).

a) La nominatio auctoris. Pensamos que tal como resulta de nuestra legislación civil, a diferencia de otros ordenamientos, la nominatio auctoris, si bien se correlaciona con casos de citación, no está diseñada de manera que pueda caber como categoría autónoma encuadrable en los supuestos del art.96 (94) CPCCN.

Parte de la doctrina argentina entiende -a diferencia de nuestro criterio- que aquélla es uno de los casos clásicos de denuncia para

\footnotetext{
${ }^{257}$ Martínez Hernán J.Procesos con sujetos múltiples,pgs 282 y 283.Segunda Edición actualizada.La Ley. Buenos Aires,2014.

${ }^{258}$ Falcón Enrique M.Tratado de Derecho Procesal Civil y Comercial, T.1 ${ }^{\circ}$ pg.452,Rubinzal-Culzoni Santa Fe-Buenos Aires.2006.
} 
intervención obligada ${ }^{259}$; al respecto, se dan como ejemplos los significados por los arts1526, 1527, 2464 y 2782 Cód.Civil. ${ }^{260}$

Otro sector de la doctrina no acepta tal criterio. Así, Podetti dice que el procedimiento de la nominatio auctoris no está reglamentado en el CPCCN pues no debe confundírselo con la intervención obligada, aunque al no estar prohibido puede aplicarse por analogía. Señala que a diferencia de la denuncia de litis, en la nominatio, el llamado excluye al demandado ocupando su lugar $^{261}$. Coincidimos con él: la nominatio no es la denuncia de litis; pero también discrepamos: al no ser tal denuncia no puede resultar de la aplicación analógica del art.96(94) CPCCN. Según Kenny la citación del legitimado para contradecir no puede ser considerado como un caso de

\footnotetext{
259 "Este tipo de intervención se verifica cuando, interpuesta una pretensión real frente a quien tiene temporariamente la posesión de una cosa ajena (a título vgr.,de inquilino, prestatario, depositario, etc.), éste pone en conocimiento del poseedor inmediato la existencia del proceso a fin de que asuma la condición de parte demandada y pueda el primero liberarse de la carga de proseguir el proceso( extramissio)". Palacio Lino E, Derecho...citado, T. III,pg.225.
}

${ }^{260}$ Palacio cita como otro ejemplo, el del demandado para la constitución de una servidumbre de tránsito que pidiera, como medio de evitar sentencias contradictorias, la citación del propietario del fundo que a su juicio proporcionaría el pasaje más corto. Refiere la opinión de Costa para quien se trataría de aplicar analógicamente la figura del tercero pretendiente ( Palacio Lino E. Derecho.. citado, T.III, nota 102 en pg. 226) Pensamos que para que dicho riesgo no exista, sería menester citar a todos y cada uno de los vecinos a la manera de un litisconsorcio necesario, improcedente para el caso, pues la sentencia que se dicte será útil en cuanto resuelve exclusivamente con respecto al predio del demandado. Este puede probar que existen otros que significan menor trayecto, cosa que no involucra a los propietarios de los mismos en la cosa juzgada, sino que llevará al rechazo de la demanda. Tampoco puede aplicarse la figura del tercero pretendiente pues aquí se trata de una situación inversa pues el eventual citado, no aspira a ocupar el extremo pasivo de la relación de servidumbre pretendida por el actor. Quizá pueda ser un caso de intervención decretada iusso iudice de acuerdo a las posibilidades que brinda la legislación italiana, pero no a la luz del CPCCN.

${ }^{261}$ Podetti Ramiro J.Obra citada, pgs340 
intervención obligada de terceros, prevista en los arts 96(94) a 98(96) CPCCN, sino como un supuesto de sustitución procesal de parte, no regulado positivamente pero al que se puede aplicar por analogía las soluciones previstas en el art.44 $\mathrm{CPCCN}^{262}$. Falcón no lo considera un caso de citación de terceros, sino de sustitución, de extromisión o de exclusión del demandado original ${ }^{263}$.

Sostenemos que no puede haber sustitución desde que, precisamente, el demandado no asume la defensa de un derecho ajeno, sino que denuncia a su verdadero titular para que éste haga tal tarea; por su parte, si el demandante no dirige su acción contra el tercero o lo hace pero conserva su pretensión contra el primitivo demandado, será porque considera que también es sujeto pasivo de la obligación que reclama y no sustituto. Si el litisdenunciante no es extromitido, su posición frente al actor consistirá en la defensa de su ajeneidad con respecto a la relación sustancial por la que se demanda y no en la defensa del derecho sustancial del que no es titular. La extromisión o exclusión del demandado primitivo, se producirá no como consecuencia de un mecanismo sustitutivo sino del desistimiento y paralelo encauzamiento subjetivo de la demanda.

Debe distinguirse entre la nominatio auctoris, instituto de derecho sustancial que procesalmente debe plantearse frente al actor como una falta de legitimación, y la denuncia de litis, presupuesto de la acción de regreso por incumplimiento contractual del denunciado con respecto al denunciante, para el caso de que el demandante no acepte liberarlo. La ley civil argentina regula la nominatio, pero no impone la litisdenuncia .A la

\footnotetext{
${ }^{262}$ Kenny Héctor Eduardo .Obra citada, pg.68

${ }^{263}$ Falcón Enrique M.Tratado..T I,pg.520
} 
vez, el CPCCN a diferencia de otras legislaciones ${ }^{264}$ no contempla la nominatio sino la denuncia.Los dispositivos que suelen utilizarse para colocar la nominatio autoris en el espectro alcanzado por el art.96(94) CPCCN, nos dan la razón: el art.2782 Cód.Civil impone al demandado por reivindicación, denunciar el nombre del sujeto por el que está poseyendo, pero no le somete a tener que citarlo por sí o a promover su llamamiento por intermedio del juez ${ }^{265}$. Similar solución contienen en materia de tenencia, los arts.2464 Cód.Civil y .2255 $\mathrm{CCCN}^{266}$.

El art. 1526 Cód. Civil, recuerda las obligaciones de garantía a las que está sometido el locador frente al locatario y que incluso pueden activarse extrajudicialmente de modo que estrictamente no hacen al sistema del art.96 CPCCN ni al de la nominatio; el art.1527 Cód.Civil impone al

\footnotetext{
${ }^{264}$ La nominatio auctoris - como aviso defensivo del deNmandado frente al actor, pone la denuncia a cargo del actor "El llamamiento al pleito del nombrado es a cargo del actor (arg.en art.1482,Cód.Civil)" (Chiovenda Giuseppe .Obra citada,t. II,v. II pg.647). Está regulada en el pgfo 76 de la ZPO alemana; en el art.59 (Llamamiento de poseedor o tenedor) del CPC Colombia, art.67 CGP de ese país, y en el art.105 (Llamamiento posesorio) del CPC Perú, en los cuales es el demandado el que denuncia al actor la real titularidad y promueve por sí la convocatoria.
}

${ }^{265}$ Art.2782 Cód.Civil. La reivindicación puede dirigirse contra el que posee en nombre de otro. Este no está obligado a responder a la acción, si declara el nombre y la residencia de la persona a cuyo nombre la tiene. Desde que lo haga, la acción debe dirigirse contra el verdadero poseedor de la cosa

${ }^{266} \mathrm{CCCN}$, art.2255.Legitimación pasiva. La acción reivindicatoria debe dirigirse contra el poseedor o tenedor del objeto, aunque lo tenga a nombre del reivindicante.

El tenedor de la cosa a nombre de un tercero puede liberarse de los efectos de la acción si individualiza al poseedor. Si no lo individualiza, queda alcanzado por los efectos de la acción, pero la sentencia no hace cosa juzgada contra el poseedor.

Cuando se trata de un automotor hurtado o robado, la acción puede dirigirse contra quien lo tiene inscripto a su nombre, quien debe ser resarcido en los términos del régimen especial. 
locador obligaciones hacia el locatario demandado, pero tampoco se refiere a un llamamiento judicial promovido por éste. Los arts.1530 y 2880 Cód.Civil obligan a locatarios y usufructuarios respectivamente, poner en conocimiento del locador o del propietario, según el caso, los acontecimientos que pudieran perturbar sus derechos pero no citarlos con el efecto que genera la del art.96(94) CPCCN. En realidad no hay ninguna norma sustancial que imponga la litisdenuntiatio ya que solamente se señalan las condiciones necesarias para la conservación de las garantías contractuales respectivas y/o la liberación por daños y perjuicios debido a la falta de aviso que no necesariamente debe darse por vía judicial, que incluso pueden operar sin la presencia de un juicio y que responden a objetivos funcionales diversos.

Pensamos entonces que, por lo menos en nuestro derecho, no puede hablarse de nominatio auctoris como un supuesto autónomo de denuncia de litis y que en cambio, producida ésta, el citado que no concurre para asumir su responsabilidad, queda en condiciones de ser sujeto de una acción de regreso por incumplimiento contractual en perjuicio del denunciante.

b) El tercero pretendiente. Otro supuesto de relaciones sustanciales conexas sin posibilidades regresivas, es el del tercero pretendiente que como vimos en la reseña del derecho extranjero, suele no tener tratamiento específico en el derecho positivo sin que por ello quede fuera del sistema de la intervención obligada. Así pasa en el CPCCN.A ello se agrega que la Exposición de Motivos sigue diciendo : "En cambio, a diferencia del criterio adoptado por algunos códigos provinciales (Mendoza, Jujuy, etc.) hemos creído conveniente no contemplar la intervención excluyente, por cuanto su funcionamiento puede ser fuente de situaciones extremadamente 
complejas, inconciliables con la mayor celeridad que se persigue imprimir al proceso. Por lo demás, pensamos que gran parte de los problemas a que dan lugar ese tipo de intervención pueden ser obviados mediante la acumulación de procesos, institución que el Proyecto reglamenta con minuciosidad". Advertimos entonces que la exposición de motivos no cierra el camino para que pueda producirse el llamamiento al tercero pretendiente: simplemente dice que no prevé,a diferencia de diversos códigos provinciales (CPCC de Jujuy ,art.79; La Rioja ,art.146;CPCC Mendoza, art.105 y CPCC Santa Fe arts.301 y 307) la intervención voluntaria destinada a defender un derecho propio, también denominada principal, vía incidental con los clásicos objetivos ad infrigendum iura utriusque competitoris a la que considera desplazada con mayor provecho por una demanda separada y la respectiva acumulación de procesos. Es razonable atribuir a la intervención voluntaria excluyente efectos complicantes en un proceso ya que puede promoverse en cualquier momento del juicio, incluso estando el mismo en la instancia superior; pero, de todos modos, no serán mucho más graves que los que puede producir la demanda autónoma que desemboca en un desarrollo acumulativo sujeto a su ritmo, y que por lo menos, entre otros inconvenientes, podrá generar, demoras en el proceso más avanzado. En cambio, no ocurrirá lo mismo con una intervención obligada en la etapa constitutiva, solución que llevará a un desarrollo procesal armónico que no interferirá en la relación citante-contraparte y no afectará al principio de continencia, al igual que ocurre en la acumulación de procesos en tanto se ajuste a los condicionamientos de ley. (art.189(188) incs 1 a 4 CPCCN).

El CPCCN, alumbrado por la Exposición de Motivos, debe ser interpretado como imposibilitando el uso de tal vía voluntaria, a la que 
considera reemplazable por una demanda autónoma acumulable ${ }^{267}$ pero en modo alguno como una prohibición de ejercer la vía de un incidente de exclusión cuando las partes de un litigio la habilitan por aplicación del art.96(94) CPCCN.

c) Conclusión. En definitiva, entendemos que los supuestos que la doctrina considera especiales (nominatio auctoris y citación del colegitimado) se traducen en casos comunes de regresivas.

La intervención excluyente que la Exposición de Motivos rechaza es la autónoma y no la incidental derivada de la denuncia de litis,de manera que queda dentro del ámbito de la intervención como mecanismo de denuncia de litis,sin perjuicio que de haber reacción por parte del citado, ella se traduzca en acumulación de pretensiones, por via incidental, quedando fuera del ámbito de la intervención obligada.

De acuerdo nuestro criterio, la intervención obligada de terceros en su modalidad genérica queda traducida en 1) casos de acciones regresivas del citante al tercero 2) tal como se señaló en el punto 1, en actitudes de abstención por parte del citado.3) como se verá,en casos de posibles reclamos del citado contra el citante.

\section{Estructura y normativa}

\footnotetext{
${ }^{267}$ Podetti actualizado, refiriéndose a una intervención voluntaria, dice que el CPCCN no prohíbe la tercería excluyente sino que simplemente no la reguló, cosa que no significa imposibilitar su planteamiento que resultaría procedente bajo la modalidad de intervención prevista en el art.92(90) CPCCN (Podetti J.Ramiro, obra citada, pg.207.). Pensamos que como el art.92(90) incs.1 y 2.CPCCN supone la adhesión, el adhesivo litisconsorcial no podría plantear una excluyente con respecto al adherido; en tanto que un coadyuvante simple no podrá deducirla por sí y para sí, pues no está en condiciones de deducir pretensiones propias.
} 
a) Estructura. $\mathrm{Si}$ analizamos estructuralmente a la intervención obligada- tanto para la intervención genérica como para la evicciónadvertimos que si bien se trata de un instituto unitario, éste se asienta en fenómeno dinámico constitutivo de un camino, un iter que van transitando partes originarias y terceros según el caso, comprensivos de varios pasos que conforman distintos objetos jurídicos encadenados y orientados hacia un resultado básico,como es el de lograr la extensión de la cosa juzgada sobre el sujeto pasivo de la denuncia de litis.

Así:

a) La litisdenunciatio o denuncia de litis como requerimiento al juez para posibilitar su concresión.

b) La citación como manera de mostrar la denuncia de litis al tercero.

c) Las consecuencias de la notificación al tercero de la denuncia de litis, fundamentalmente la extensión de la cosa juzgada.

d) La abstención o no concurrencia del tercero.

e) La comparecencia y la función del tercero adentrado en el proceso ajustada a la coadyuvación.

f) La posible formación litisconsorcial.

b) Normativa. El art. $96 \mathrm{CPCCN}$ dice: "Intervención obligada. El actor en el escrito de demanda, y el demandado dentro del plazo para oponer excepciones previas o para contestar la demanda, según la naturaleza del juicio, podrán solicitar la citación de aquél a cuyo respecto 
consideraren que la controversia es común. La citación se hará en la forma dispuesta por los artículos 339 y siguientes,

Como puede verse, el art.96, ubicado dentro del Capítulo VIII, Título I, Libro I, CPCCN se titula "Intervención obligada". Es en ese lugar y no en el cuerpo del dispositivo donde se hace referencia a la situación jurídica en la que queda el tercero una vez puesto en conocimiento de la litis denunciada. En su contenido, el artículo establece la oportunidad y presupuestos necesarios para producir la citación, viable en cuanto el denunciante considere que media "controversia común" y reúna los demás presupuestos requeribles. El complemento fundamental del sistema aparece en otra norma: se trata del art. 96(94) $\mathrm{CPCCN}$ en cuanto determina que concurra o no el citado, será alcanzado por la cosa juzgada resultante del pleito en el que se produce la citación.

${ }^{268}$ Con textos iguales al CPCCN, pero cambiando el número del artículo al que se remiten: CPCC Buenos Aires, art.94,CPCC Catamarca, art.94, CPCC Chaco, art.94, CPCC Chubut, art.95, CPCC Corrientes, art.94, CPCC Entre Ríos, art.91, CPCC Formosa, art.94,CPCC La Pampa, art.85, CPCC Misiones, art.94, CPCC Neuquén,art.94,CPCC Río Negro, art.94 , CPCC San Luis, art.94 , CPCC Santa Cruz, art.94 ,CPCC Santiago del Estero ,art.97, CPCC Salta, art.94,CPCC Tucumán, art.90, CPCC Tierra del Fuego,art.103.

CPCC Córdoba: art.433. "El actor en la demanda y el demandado dentro del plazo para contestarla, podrán solicitar la citación de aquél a cuyo respecto consideraren que la controversia es común”.

CPC Mendoza. Coincidencia con art.25 .I.(Ver texto en punto 33) 


\section{SECCION SEGUNDA}

\section{LA DENUNCIA DE LITIS}

\section{La citación. Precisiones terminológicas}

La palabra citación se vincula habitualmente a un contenido de llamamiento o requerimiento de autoridad para la presencia en un sitio determinado a los fines de una diligencia; ya con respecto a la actividad judicial, comparecencia a una diligencia del proceso, arribo que puede conllevar la presencia física del citado o solamente su concurrencia jurídica. Tal contenido se pone en conocimiento del destinatario mediante la notificación, verdadero instrumento de la citación. La citación puede tener diversos sentidos a saber:

a) de incitación compulsiva a concurrir materialmente a las audiencias del pleito, con efectos sancionatorios (por ejemplo citación a testigos y peritos) o sin ellos (por ejemplo, a las partes a los fines instructorios (arts 396(394), 361(360),405(404) y410(409) CPCCN)o conciliatorios(art.36 inc. 2$)^{\mathbf{2 6 9}}$.

b) de incitación a concurrencia forzada dentro de un lapso con el inherente sistema de cargas (por ejemplo, el traslado de la demanda, la "citación" del actor al asegurador del responsable (art.118 ley de seguros),

\footnotetext{
${ }^{269}$ Aun cuando diversos tribunales aplican llamados de atención a las partes no concurrentes por considerar que la ausencia injustificada importa falta de respeto al tribunal.
} 
la citación para integrar la litis en el litisconsorcio necesario, la orden de subasta con citación a acreedores embargantes, hipotecarios y prendarios; al ministerio público para posibilitar su intervención).

c) de noticia para posibilitar una concurrencia optativa a un pleito en el que se discutirá un tema que es común a la relación que un tercero pueda tener con la parte que promueve la citación. Se trata de la denuncia de litis, el paso que genera la intervención obligada.

El concepto de citación va unido necesariamente a un sujeto impulsor al que la doctrina y a veces las normas positivas denominan "citante", palabra que por su uso generalizado podemos aceptar; sin embargo si advertimos que en nuestro derecho no hay otro citante que el juez ni otra citación con efectos de denuncia de litis que la que ordena el magistrado, podemos reemplazarla con mayor propiedad con la denunciante o litis denunciante, identificando con ello al que requiere y promueve la citación judicial. De todos modos utilizaremos indistintamente una u otra forma, con preferencia la segunda. Con respecto al tercero, si bien corresponde distinguir su situación jurídica según se encuentre o no citado, lo identificaremos indistintamente como "tercero", "citado" o "tercero citado" .

\section{La denuncia de litis}

El primero de los objetos jurídicos a considerar dentro del instituto de la intervención obligada de terceros, es la denuncia de litis. La denuncia de litis, se encuentra implícita en la redacción del art.96(94) CPCCN ya que en la misma se refiere solamente a la citación, manera de exteriorizarla 
ante el tercero, su destinatario. Formalmente la denuncia resulta ser un objeto dinámico que muestra dos momentos: el de su planteamiento y el de su concresión. Aparte, habrá que considerarla en su naturaleza.

En cuanto a su planteamiento, definiremos la denuncia de litis como la manifestación de voluntad formulada fundadamente ante el órgano jurisdiccional, proveniente de los litigantes originarios de un proceso, por la que se decide hacer saber a un tercero la existencia de un litigio en el que el litisdenunciante discute con su contraparte, una cuestión que es la misma que contiene la relación jurídica que le vincula con dicho tercero. En su elaboración subjetiva, la denuncia de litis conlleva el propósito e interés del litisdenunciante en producir determinados efectos jurídicos sobre su relación con el citado, en especial, la cosa juzgada relativa a la cuestión común.

Como concresión, la denuncia de litis es la notificación al tercero de la decisión judicial por la que queda citado a pedido de parte y en los términos de ley, con lo que toma conocimiento de la existencia de la causa y de la consiguiente voluntad de parte, de hacérselo conocer. Con ello, el tercero citado sabe de las consecuencias jurídicas a las que queda sujeto (arts.20 Cód.Civil y $8 \mathrm{CCCN}$ ).

Es claro que una cosa es la denuncia de litis y otra bien distinta la manera en la que el citado reacciona ante ella, ya que como lo veremos y según los casos ,si bien puede permanecer como tercero en concurrencia o abstención,también puede abandonar el papel de tercero para pasar a demandar o convertirse en demandado.

\section{Naturaleza de la denuncia de litis}


El problema de la naturaleza de la denuncia de litis consiste básicamente en determinar si, como expresión de voluntad del denunciante, se limita a un aviso de la existencia del pleito destinada a producir diversas consecuencias, distintas, total o parcialmente, de las que una demanda genera en el demandado, o si constituye una pretensión planteada contra el citado, traducida en demanda o en alguna otra forma equivalente.

Las teorías que pueden vincularse con el tema han sido formuladas en el derecho europeo y son recogidas por seguidores en el derecho sudamericano y en particular en el argentino. Tratando de esquematizarlas y teniendo en cuenta el pensamiento de los autores más difundidos entre nosotros y que glosáramos en los puntos 17 y 18, destacamos dos líneas a las que identificamos con las denominaciones que exponemos:

a) Teoría del anuncio con extensión de la cosa juzgada. Según la misma la denuncia de litis tiene el significado de un aviso al tercero de la existencia de un pleito cuya cosa juzgada, en virtud de tal noticia, podrá extenderse sobre dicho sujeto. Por ende no importa el ejercicio de una acción contra el tercero Es sostenida por los autores alemanes en torno del contenido de la ZPO y por Chiovenda. Es la tesis que en el derecho argentino sostienen Palacio y Falcón ${ }^{270}$ entre otros autores que conforman una línea mayoritaria. Muestra ciertas variantes en cuanto a si importa una invitación a la concurrencia del citado (Chiovenda) o si es totalmente neutra al respecto (Wach).

\footnotetext{
${ }^{270}$ Palacio Lino E. Obra citada, T.III, pg 212 y 213; Falcón Enrique M.Tratado..citado ,T.1 ${ }^{\circ}$,pg.478.V en el punto 48 las ideas de Martínez al respecto.
} 
b) Teoría del valor de la llamada en causa como demanda. Así 1lamamos a la postura sostenida en Italia por Calamandrei ${ }^{271}$, para quien el llamamiento en causa sirve o tiene el contenido, según el caso, de mero aviso habilitándole con ello para participar del juicio; o como manera de proponer una acción de condena contra el tercero; o como modalidad de desarrollar una pretensión declarativa del citante contra el citado con alcance limitado a la cuestión común. Será mero aviso si se denuncia la litis a un tercero contra el que el citante no tiene derecho a reclamar (ejemplo, el acreedor demandante que cita a su coacreedor avisándole para que concurra al juicio contra el deudor); pero también si lo tuviere pero se lo limita a que acuda a defenderlo (ejemplo el garantizado que cita al garante en la garantía formal ,caso del art.1485 Cód.Civil italiano);será demanda de condena cuando exista una obligación de resarcimiento por parte del tercero y se deduzca el consiguiente reclamo de repetición; y demanda declarativa limitada a la cuestión común, cuando el citante no tenga acción contra el tercero y solamente quiera extender a su respecto la cosa juzgada. Resaltamos entonces que para Calamandrei la denuncia de litis propiamente dicha se da cuando el citante no pretende ningún resarcimiento por parte del tercero y solo le avisa de la existencia del pleito ; en los demás casos hay demanda, pero en el intento de extender la cosa

\footnotetext{
${ }^{271}$ Las ideas de Calamandrei empalman con la concepción de Carnelutti sobre la acumulación de litis. Siguiendo a Calamandrei puede verse entre nosotros la opinión de Kenny "En razón de las consideraciones precedentes, puedo sostener, como principio general, que el pedido de citación del tercero, efectuado por una de las partes originarias y con el objeto de que aquél intervenga obligadamente en el proceso a fin de que la sentencia lo alcance, importará para el citante la formulación de una pretensión de mera declaración de certeza (positiva o negativa) de derechos emanados de la relación o situación jurídica externa habida entre una de las partes y un tercero, y que está dirigida a ese limitado efecto contra este último" (Kenny Héctor E. Obra citada. pgs 36 , 37,68 y 69).
} 
juzgada, parece dudar pues no sostiene que es, sino que "vale" por menos como una demanda.

\section{Opinión propia}

Anticipamos que si bien con variantes que resultan de ideas propias, nuestra posición coincide con la concepción germana de la denuncia de litis expresada por Wach.

Debe tenerse en cuenta que Calamandrei no habla de denuncia de litis sino de llamada en causa. Si bien en todo caso de llamada en causa convive una denuncia de litis, ésta solo se mantiene como tal cuando el citante no tiene derecho que reclamar del citado-o no lo quiere poner en acto- y solo le avisa de la existencia del juicio. En cambio cuando tiene tal derecho, la denuncia se diluye, pero sin perder su entidad formal pero si su trascendencia ya que queda superada por la demanda y con ello se produce el fenómeno de la acumulación de causas o de litis al decir de Carnelutti. Pero entonces vemos que la concepción del autor italiano no puede darse entre nosotros. En efecto, si la litisdenuncia es, contiene o se transforma en demanda, para satisfacerla abría que entrar a juzgar conjuntamente con la litis entre contraparte y citante la responsabilidad del segundo frente al primero solución inadmisible al no aceptar nuestro derecho pronunciamientos jurisdiccionales en abstracto ni aun a título meramente declarativo, tal como lo hemos demostrado en los puntos 4 a $\mathbf{6}^{272}$; o bien

\footnotetext{
${ }^{272}$ La sentencia resultante no estaría resolviendo un caso de actual incertidumbre objetiva sino un supuesto correspondiente a una relación sustancial -la derivada de daños y perjuicios-no nacida.
} 
declarar que la cosa juzgada sobre la cuestión común será aplicable en su momento para resolver sobe la responsabilidad del tercero contra el citante , pronunciamiento inútil pues no haría sino repetir el significado de la ley.

En realidad, en nuestro sistema la extensión de la cosa juzgada sobre el tercero aun limitada a la cuestión común, no es el resultado de una pretensión que imponga un pronunciamiento judicial al respecto, sino de la ley que extiende sobre el tercero los efectos del fallo con aquél límite, sin entrar a juzgar sobre la real existencia de su responsabilidad o la subsistencia de la misma. En otras palabras, la demanda del litisdenunciante resultaría inocua para generar el efecto de cosa juzgada pues el mismo se da de pleno derecho, a condición de que el tercero esté legalmente avisado de la existencia del juicio en el que tal fenómeno puede producirse.

La presencia de una demanda- aun cuando estuviese referida exclusivamente a declarar al demandado sujeto a la obligación de defender al citante o a quedar sometido a la cosa juzgada sobre la cuestión comúnhabilitaría al accionado a impugnar la admisibilidad y/o improcedencia de la denuncia de litis, cosa que aparece prohibida por el sistema del CPCCN por aplicación analógica del art.108(106) CPCCN.

La letra normativa dispone que la citación se practique en la forma dispuesta por el art.339 y siguientes del CPCCN, es decir de la manera en que se notifica la demanda, pero no expresa que se trate de una demanda. Si así fuese -sea por una pretensión de condena o sea por una declarativatendría que ser deducida con todos los requisitos que impone el art.330 CPCCN con más los que hacen a la oferta de prueba, a los que debería agregarse una orden de traslado en tiempo prefijado legalmente para contestarla con el nacimiento de las cargas del caso. En cambio, como 
veremos, la viabilidad de la denuncia de litis no precisa sino de fundamentación exclusivamente referida a la verosimilitud de la existencia de relación conexa creadora de vínculos obligacionales entre denunciante y tercero.

La incompatibilidad entre el sistema del planteamiento de una pretensión y de su traslado con el del art.96(94) y concordantes del CPCCN resulta patente: así en caso de incomparecencia, el art.98(96) CPCCN impone como solución automática la extensión sin más de la cosa juzgada ; esa consecuencia que no sería viable ante una demanda ya que entonces jugarían los sistemas de rebeldía( o por lo menos el del art.357 (356)CPCCN) con la necesidad de seguir la secuela del juicio y practicar notificaciones específicas (arts.61(59),y 62(60)). El denunciante no requiere del órgano judicial más que una orden de citación, de manera que el principio de congruencia impide que ,oficiosamente ,el tribunal pueda interpretar que se está demandando.

Es prudente dejar asentado que lo expuesto no se ve alterado por la opinión que vertimos en el punto $\mathbf{1 0 2}$ b acerca de la posibilidad ejecutoria sobre el tercero que nace de la tercera parte del art.96(94) CPCCN que, como explicamos en ese lugar, no resulta de una demanda del citante sino de la propia e implícita aceptación por parte del citado concurrente.

En el caso del tercero pretendiente-tal como lo concebimos (ver al respecto el punto 56)-se pone más de manifiesto la distinción entre citación y demanda.En efecto,si fuera lo segundo, el denunciante devenido en demandante tendría que otorgar entidad suficiente a la titularidad del citado como para merecer debatirla, cosa que desmerecería su posición frente al demandado; si fuese demandado, no se ve qué pueda tener interés en demandar al tercero asumiendo las cargas consiguientes, entre ellas la 
afirmación acerca de la titularidad activa del tercero. El carácter declarativo que podría atribuirse a la demanda por la situación de duda generada ante la presencia de un pretendiente, mostrará los mismos inconvenientes pues el demandante tendría que partir de la ,aun negándola,de la trascendencia de laposición del tercero. Distinto es colocar al tercero en situación de tener que asumir el planteamiento de una pretensión excluyente, objetivo que se logra con la denuncia de litis y el efecto de cosa juzgada que produce.

Es claro que Calamandrei se esfuerza por encontrar la manera de dar calidad de parte al tercero para justificar con ella el efecto extensivo de la cosa juzgada. Nosotros pensamos que la demanda o su contestación, no son las únicas fuentes capaces de otorgar aquella condición, tema por el cual nos remitimos a lo expuesto en los puntos 68 y 94 .

En definitiva pensamos que la denuncia de litis tiene por naturaleza ser un medio de aviso al tercero sin incitación a su concurrencia, productor de diversos efectos jurídicos sobre dicho sujeto, que no obstante no constituir el planteamiento de una pretensión en su contra, lo vinculan con la cosa juzgada que pudiera resultar del pleito con relación a la cuestión común.

\section{Iniciativa de la denuncia de litis}

a)Denuncia de litis dispositiva. Según la legislación que consideremos, la denuncia de litis con su objetivo propio de generar cosa jugada, puede ser dispositiva -a iniciativa de parte- así como provocada por la voluntad judicial .Ya vimos como ello ocurre en otros países. 
Ciñéndonos al CPCCN, el art.96(94) pone en cabeza de la parte interesada la petición -según su interés- destinada a lograr la denuncia de la litis al tercero

b) Citación obligada judicial. Vimos en el punto $\mathbf{4 8}$ b los diversos motivos que fuera de la intervención obligada de terceros pueden justificar la citación oficiosa.

Con respecto a tal modalidad de intervención, en el derecho procesal argentino si bien el CPCCN (así como sus seguidores) no prohíbe a los jueces formular citaciones por propia iniciativa en casos de controversias comunes, la interpretación a contrario del art.96(94) CPCCN -lo mismo ocurre con el art.97 CPC Jujuy y con el art.25.1 CPC Mendoza- indica que esa posibilidad está reservada a las partes, de modo que la ley no tiene interés en promover la participación de terceros en los juicios en trámite con miras a acciones futuras. En coincidencia con esa solución, el CPCC Santa Fe, establece que salvo expresa disposición, solamente puede citarse oficiosamente en el litisconsorcio necesario (art.303).

Por el contrario, la iniciativa judicial en la materia está admitida en el CPCC de La Rioja. En tal sentido, el art.147 refiere la intervención coactiva del tercero excluyente dispuesta de oficio, y en el art.148 similar posibilidad para la intervención coactiva del tercero coadyuvante.

\section{9:Disponibilidad del derecho o carga de denunciar?}

a) Planteamiento. Podemos preguntarnos si denunciar al tercero la existencia de la litis es o no una carga procesal; para respondernos comenzaremos por un breve análisis del concepto de carga procesal, 
b) Carga procesal. Es preciso distinguir entre el derecho de disponer de los derechos subjetivos, la carga procesal y el derecho a disponer el cumplimiento o no de las cargas.

Todo titular de derechos sustanciales puede decidir acerca de su defensa o abandono (derecho de disposición material); enfrentado con un juicio, goza del derecho de disposición procesal que le permite decidir libremente acerca del cumplimiento o no de los actos procesales que potencialmente puede llevar a cabo. Sin embargo, el ejercicio de esta libertad puede acarrearle consecuencias diversas si se enfrenta con una carga procesal.

La carga es, según la conocida definición, un imperativo del propio interés. Corregimos tal versión diciendo que la carga es heterónoma y por ende ajena a la valoración y al manejo subjetivo, ya que la impone el orden jurídico como una necesidad de la jurisdicción llamada a resolver un conflicto. La carga existe, precisamente, por su condición de factor que la pone fuera del alcance de la voluntad de los sujetos. Cumplirla o no, eso sí es imperativo del propio interés ${ }^{273}$ y en ello se juega el derecho de disposición procesal ${ }^{274}$. La carga es resultante de la necesidad de la jurisdicción de a) desarrollar el proceso en forma ordenada para llegar a la sentencia ( por ejemplo, la carga de comparecer y cumplir con los actos procesales en tiempo oportuno), b) habilitar la actividad judicial (por ejemplo recurrir), c) obtener elementos de juicio para poder resolver el

\footnotetext{
${ }^{273}$ Rivas Adolfo A. Teoría General del proceso, pgs 320 y 321.Lexis Nexis. Buenos Aires.2005.

${ }^{274}$ El derecho de disposición procesal es diverso aunque conexo, del derecho de disponibilidad sustancial del objeto litigioso; este último permitirá al titular defenderlo o no; enajenarlo o cederlo, pero ello no interferirá en el sistema de cargas en tanto aquél se encuentre sometido a la jurisdicción.
} 
conflicto (por ejemplo la carga de la prueba ). No atender a una carga traerá alguna consecuencia negativa -directa o indirecta- para el incumplidor (no comparecer siendo demandado puede acarrear la rebeldía; no contestar la demanda, hará perder la oportunidad de controvertir la posición contraria; no cumplir con la carga probatoria llevará a no tener acreditado los hechos alegados; no apelar dejará firme la sentencia desfavorable al que omite hacerlo ); y como contrapartida, normalmente aunque no siempre, un mejoramiento de la situación del contrario. Es claro entonces que el derecho de disposición procesal no libera al sujeto litigante de las consecuencias negativas que pueda producir el incumplimiento de una carga.

La demanda importa un acto de disposición del derecho sustancial al iniciarse su defensa judicial. En sí misma, plantearla, como acto voluntario, no es una carga; pero constituye el proceso y desde su formalización y junto con ella, somete al sujeto devenido en actor al sistema de cargas con la inherente disposición procesal; a partir de entonces y cumplida la de trasladar la demanda, dicho sistema empieza a jugar para el demandado. Este pasa a ser parte potencial desde la notificación: si en uso de su poder de disposición procesal comparece, será parte constituida; sino no lo hace, será parte con posibilidad de constituirse materialmente pero de todos modos sometida a la vocatio, al sistema de cargas y en definitiva, a la cosa juzgada con la que quedará resuelto el conflicto.

La jurisprudencia tiene determinado que no es imperativo para las partes originarias promover la citación para intervención obligada de 
tercero, por más que pueda configurarse un caso en el que su participación resulte objetivamente justificada ${ }^{275}$.

El mismo texto del art.96 (94) CPCCN avala tal solución desde que emplea el término "podrán" que indica la presencia de una facultad de elección. Esa facultad significa implícita pero claramente, la existencia de un derecho procesal a hacer citar, disponible para su titular que puede ejercitarlo o no, y que solo puede ser practicado por una parte efectiva, es decir ya reconocida por haberse presentado a juicio y por ende ya sometida al sistema de cargas que le impone. De tal manera concluimos que denunciar la litis o no hacerlo, no es una carga sino un paso de disposición del derecho sustancial, pero en caso de optarse por el primer camino, es carga producirlo en momento oportuno y con los actos necesarios para la posibilitar la concurrencia del tercero. El incumplimiento dará lugar a la pérdida del derecho de citar con los efectos del art.98(96) CPCCN.

\section{La denuncia de litis y sus clases}

En definitiva y considerando lo expuesto en los puntos anteriores, pensamos que si se tiene en cuenta que los supuestos de denuncia de litis a co-legitimados cuando hay derechos creditorios a favor del citante contra el citado y los de nominatio auctoris se reducen a denuncias regresivas, el sistema de los arts.96 (94) y 98 (96) CPCCN permite dividirla en tres clases: denuncias de litis regresivas, denuncias de litis extensivas y denuncia de litis excluyentes. Esta división no impide que tales categorías

\footnotetext{
${ }^{275}$ CN Civ Sala D 23/6/76 Consorcio de Propietarios Avda Libertador 662 c/Rivarola Roberto. ED 71-212
} 
deban asentarse en la existencia de presupuestos comunes así como de formas de gestionarse únicas, si bien podemos encontrar diferencias en la manera en la que la cosa juzgada puede pesar sobre el tercero y en las distintas conductas que podrá asumir ante la citación.

\section{Denuncias de litis regresivas .Concepto y clasificación}

a) Concepto. Las denuncias de litis regresivas son la que pueden requerir las partes originarias con el fin de tener un presupuesto o antecedente que les permita repetir de un tercero, aquello que debieron desembolsar o perder con motivo del juicio en el que se produjo el llamamiento.

Las denuncias de litis regresivas tienen un objetivo básico, como lo es el dejar expedita la práctica de una acción de cobro del citante contra el citado al amparo de la cosa juzgada, y tres consecuencias eventuales: habilitar el acceso del citado para apoyar al citante; la posibilidad de que el demandante accione contra el tercero citado al mostrarlo como un posible legitimado pasivo y, por último, la obturación de los caminos defensivos del citado. En efecto, de no practicarse la denuncia al tercero, éste, entre otras maneras de oponerse al litisdenunciante cuando lo demandare, podría poner en tela de juicio la eficacia de las defensas utilizadas por el citante frente a su adversario (exceptio mali defensa), liberándose con ello de la obligación de resarcirlo ya que la derrota resultaria obra de su propia torpeza, todo salvo que se demuestre por el demandante que la intervención del tercero no hubiese tenido eficacia frente a la contraparte. 
Como se podrá observar, en las denuncias regresivas no se acumulan pretensiones sino que se llama a los terceros a incorporarse al debate de la pretensión existente, no porqué se los esté demandando sino porque lo resuelto puede ser utilizado como presupuesto con fuerza de cosa juzgada en el pleito futuro. En realidad el tercero, en cuanto partícipe de la cuestión común, concurre a defender preventivamente su derecho si bien lo hará mediante maneras indirectas, características de especiales modalidades de coadyuvación. Ello nos fuerza a estudiar en que condición, con qué sustento y a qué fines ingresa el tercero, tema que será abordado en los puntos 94 a 96.

b) Clasificación. Abarcan todos los supuestos en los que el regreso del citante contra el tercero pueda ser practicable según las fuentes obligacionales factibles de convertirlo en deudor del litisdenunciante,con exclusión de los casos en que la responsabilidad resulte de perjuicios causados en bienes del citante a cargo del citado (denuncia de litis extensivas) .Obviamente que también excluye a las denuncias de finalidad excluyente Así, admite división teniéndose en cuenta tales elementos en:

a) denuncias de litis regresivas por responsabilidad, divisible a la vez según se trate de responsabilidad cuasidelictual, contractual y derivada.

b) denuncia de litis regresivas por contribución, para los casos en que por ley o contractualmente, el actor o demandado pueden convocar a sus coacreedores o codeudores obligados a aportar al citado sendas partes del total que éste hubiese desembolsado como consecuencia del juicio. 


\section{Ejemplificación}

a)Denuncia de Litis regresiva por responsabilidad cuasidelictual. Teniéndose en cuenta el principio resultante del art.1082 Cód.Civil que no permite reclamos entre los autores, consejeros y cómplices de un delito,la acción de regreso del demandado contra terceros responsables, será viable en materia cuasidelictual en base a relaciones de solidaridad y concurrencia (arts1109 y 113 Cód.Civil;arts 1716,1717,1724,1749 1751 CCCN).

b) Denuncias de litis regresivas por responsabilidad contractual. Los incumplimientos contractuales encuadrables en los arts.505, 506. 508, 511 Cód. Civil;ejemplo,caso de un proveedor ( A) que al no cumplirse con la provisión de determinados por parte de un tercero (C) no pudo satisfacer a la vez con lo comprometido con $\mathrm{B}$ que lo demanda por los perjuicios sufridos como consecuencia (arts.1721,1723,1724,1728 FCC); citación al proyectista formulada por el director de la obra o a la inversa al ser demandados por el dueño del edificio (art.1646 tercera parte Cód.Civil) en caso de haber sido contratado por el constructor; concesionario demandado por los defectos de la cosa adquirida que llama al concedente por la responsabilidad que puede caberle; la que quiera activar el usufructuario a título oneroso con respecto al nudo propietario (art.2915 Cód.Civil) o el locatario con respecto al locador (art.1527 Cód.Civil) con el objeto de preservar un eventual reclamo por los daños que sufriera en sus derechos sobre las cosa arrendada como consecuencia del juicio en el que se produjo el llamamiento ${ }^{276}$; el principal demandado directamente por los actos de

\footnotetext{
${ }^{276}$ Ver en el punto 55 la diferencia entre citar para cumplir con las obligaciones impuestas por la ley o el contrato al usufructuario, al locador o al sub locador con
} 
sus dependientes,que los cita en supuestos de delitos o cuasi delitos (arts 1096,1113, 1122 y 1123 Cód.Civil; arts 1716,1717,1749 y 1757 CCCN); el que se sirve de un animal causante del daño citando al propietario, en la hipótesis de la segunda parte in fine del art.1124 Cód.Civil; los casos derivados del art.1113 en los que, a raíz de la demanda planteada por el damnificado, pueda darse acción de repetición del propietario demandado contra el responsable-guardador o del guardador demandado contra el dueño de la cosa. El fiador que cita al deudor (art.2029 y 2030 Cód.Civil y art.1592 CCCN). En esta categoría entran también evicción y aseguramiento aun cuando ya advertimos que salvo las referencias hechas oportunamente, no son objeto de este estudio. Con las características que resultan de lo expuesto en el punto $42 \mathrm{c}$, incluimos el caso del llamamiento al legitimado para intervenir (nominatio auctoris) cuando no concurre a la defensa del demandado. También caben los casos responsabilidad por la conducta de sus dependientes, cuando demandado el Estado, llama de regreso al autor de la conducta dañosa. Al respecto habrá que tener en cuenta las disposiciones del CCCN (arts.1765 y 1766).

c) Denuncias de litis regresivas por responsabilidad derivada. $\mathrm{Se}$ trata de casos en los cuales se imputa responsabilidad al estado (nacional o provincial o enventualmente municipal) por ser el autor del marco legislativo al que se ajustó el demandado, al que se atribuye, por esa sujeción, ser el autor directo de perjuicio al demandante. Como consecuencia de tal situación se plantea, por lo general por la actora y a veces por la parte demandada, la inconstitucionalidad de normas generales

respecto al nudo propietario, el propietario o locador principal y citar para preparar una acción de regreso y la manera en que la citación puede servir a ambos efectos. 
al tiempo que se cita al estado como tercero en función del art.96(94) CPCCN

En tal sentido la Corte Suprema ha generado una casuística que no resulta fácil de sistematizar al no poder tener acceso a los juicios respectivos. De todos modos es factible distinguir tres tipos de casos:1) Cuando el actor cuestiona la constitucionalidad de normas provinciales por oponerse al ordenamiento federal y pide la citación del Estado Nacional como tercero, 2) Cuando el actor pide citación del Estado Nacional en razón de ser emisor de normas generales, 3) Cuando la demandada pide la citación estatal en previsión de acciones regresivas en su contra ${ }^{277}$. Ver

${ }^{277}$ Caso $n^{\circ} 1$ YPF c/Pcia de Neuquén CS Fallos 329:4829.Puede pensarse en una citación al colegitimado activo sin derecho de acción en su contra. El tribunal no hizo lugar sosteniendo que la fijación de políticas hidrocarburíferas y la calidad de concedente de concesiones no justificaba el llamamiento. Iguales fundamentos en CS. 6/5/2007 Petrolera Entre Lomas S.A.c/Pcia de Neuquén, acción declarativa por liquidación de regalías provinciales (ED 223-227)

Caso $\mathrm{n}^{\mathrm{o}}$ 2. No corresponde hacer lugar al pedido de citación del Estado Nacional como tercero si solo se lo vincula a la causa por haber emitido la legislación general en la materia de la que se trate o fijado las políticas correspondientes. Droguería Oricofarrmo SRL c/Pcia de Tucumán, fallo del 12/12/2006 (Fallos 329:5675); Pluspetrol S.A. c/Provincia de Neuquén s/liquidación de regalías, fallo del (Fallos 329:4823); Pedro Juan Porta c/Provincia de Buenos Aires, fallo del 24/10/2006; especialmente el Dr.Fayt señaló que resultaba extemporáneo pedir por el actor la citación del Estado Nacional cuando la demandada, en el responde, sostuvo que la declaración de inconstitucionalidad de normas locales pedida por la actora, provocaría similar la declaración de las normas federales en las que se basaron. Precisa que si se considerara procedente el pedido habría que aplicar la solución del art.96 (94) CPCCN en todo caso de planteo de inconstitucionalidad de normas, tema que debe ser resuelto entre las partes (CS Fallos 329:4465).

Caso $\mathrm{n}^{\circ}$ 3. A raíz de la normas nacionales que dispusieron la pesificación de los créditos y depósitos bancarios en dólares, un particular demanda al estado provincial y éste pide citación por el art.96 (94) CPCCN al Estado Nacional.La CS hizo lugar al pedido (causa Traini Alberto c/Pcia de Neuquén del 27/12/2006.Fallos 329:6038.Caso de litisdenuncia regresiva. 
igualmente el punto 65 c específicamente referido a la jurisprudencia de la CS en materia de proceso colectivos.

d) Denuncias de litis regresivas por contribución. El coautor de un cuasidelito, reclama de los coautores para la restitución de la parte de condena que a ello hubiese correspondido (art.1109 segunda parte Cód.Civil; art.1751 CCCN); citación de obligados en obligaciones divisibles o indivisibles cumplidas por un solo deudor (art.689 Cód.Civil); el fiador demandado por el acreedor con respecto a los demás cofiadores(art.2037 y 2038 Cód.Civil, art.1595 CCCN); el legitimado activo en la reivindicación, con respecto a los colegitimados no demandantes por los desembolsos que tuviere que hacer en caso de derrota ; los de un condómino contra los otros en materia de juicios por gastos en beneficio de todos (art.2687 Cód.Civil); o del tercer poseedor del inmueble hipotecado con respecto a los titulares de otros inmuebles sometidos a la misma hipoteca (art.3171 Cód.Civil); en materia de usufructo, los

En otro caso, se trató de una demanda de petición de herencia planteada sobre el $50 \%$ de la indemnización que percibiera el heredero demandado, beneficiario del total de la compensación que la leyes 24.441y 24.832 establecieran en favor de descendientes de desaparecidos durante el último gobierno militar. La demandada planteó la inconstitucionalidad del veto parcial a la última de esas leyes, producido por el decreto 479/1997, a raíz del cual se eliminó la disposición por la que el actor quedaba en posición de reclamar del Estado una indemnización similar a la ya cobrada por el otro heredero. La accionada sostuvo que de prosperar la declaración de inconstitucionalidad, la controversia podría ser común a tal sujeto pues resultaría obligado al pago de una indemnización similar a la que recibiera. La Corte Suprema., siguiendo fielmente el dictamen de la procuradoría general revocó lo decidido por las instancias ordinarias y dispuso hacer lugar al pedido de citación de tercero en virtud del art.96 (94) CPCCN. En definitiva, el demandado apuntó con su pedido, a preparar una acción regresiva contra el Estado para el caso de que, a raíz del cambio normativo derivado del veto, tuviera que compartir con otro coheredero la indemnización percibida.( CS fallo del 5/3/2013,ED 252-323). 
supuestos de reclamaciones derivadas de lo dispuesto por el art.2909 Cód.Civil .Ver en el punto 55, el tema de la denuncia de litis y las obligaciones solidarias .

\section{Notificaciones de apariencia litisdenuncial regresiva}

La ley sustancial prevé en determinados casos la obligación de hacer saber a otros sujetos la existencia de acontecimientos -jurisdiccionales o no- que puedan afectar los derechos de los mismos. Se trata de anoticiamientos que no tienen la finalidad de la litisdenuntiatio ni la norma exige que se hagan judicialmente o específicamente por el sistema de los arts 96(94) y 97(95) CPCCN. Son las notificaciones que llamamos defensivas (previstas para evitar la caducidad de la garantía que debida por el tercero al citante, por ejemplo, si el locatario omite denunciar al locador las novedades y acciones previstas en el art.1530 parte final Cód.Civil) y previsoras (apuntan a evitar que el garante quede habilitado para deducir una pretensión por daños y perjuicios contra el obligado por los costos y consecuencias que sufriera por no haber producido llamamiento oportuno ante determinadas situaciones; por ejemplo, para el locatario la denuncia al locador de los hechos previstos en el art.1530 Cód.Civil o para el usufructuario similar obligación con respecto al propietario(art.2880 del mismo código).

Es claro que la denuncia de litis formalizada en las condiciones marcadas por la ley procesal puede servir para que a través de la misma, se cumplan los fines contemplados por la ley sustancial pero, a la inversa, los avisos extrajudiciales o judiciales que se hagan fuera de ese contexto 
jurídico no valdrán como litisdenuncias aun cuando puedan servir a los fines obligacionales (por ejemplo, la citación como testigo a la causa en la que pudo llamársele como tercero; un pedido de informes o un requerimiento de presentación de prueba documental).

\section{Denuncias de litis extensivas}

Las denuncias de litis extensivas son las destinadas a generar el efecto de cosa juzgada a terceros con el objetivo de evitar los reclamos del tercero al litisdenunciante, al dejarlo en situación de comparecer y suplir con su actividad los defectos de la del litisdenunciante en lo referente a su responsabilidad en la custodia del derecho del tercero ${ }^{278}$. Por ejemplo, citación pedida por el acreedor prendario al tercero, titular del bien prendado,en los supuestos de prenda con desplazamiento (art.3205 Cód.Civil párrafo final o la de igual acreedor al mismo titular al emprender una acción reivindicatoria del bien (art.2221 CCCN); la del consignatario al consignante en el contrato de consignación (art $1338 \mathrm{CCCN}$ ); la del depositario al depositante en el contrato de depósito (art.1356 Cód.Civil); la del fiduciario con respecto al fiduciante en el contrato de fidecomiso (art.1666 CCCN).Ver en el punto siguiente el caso de citación al coacreedor solidario en virtud de los art.707 Cód.Civil y 846 CCCN.

Si el citado no concurre, de todos modos pesa sobre él efecto extensivo de la cosa juzgada en lo que hace a la cuestión común, y el citante quedará

\footnotetext{
278 Se tratade los supuestos comprendidos en el pgfo 72 dela ZPO cuando refiere al que actua "cuidando el derecho del tercero". En elpunto 17,pueden verse las referencias al tema que formulan Kisch y Schonke.Ver igualmente, aart.342 del Proyecto Alcorta-Zeballos.
} 
cubierto de la mala defensa que pudiera imputársele. Si el tercero pudiera tener acción con respecto a la contraparte del litidenunciante deberá ejercitarla abandonando así el papel tercerista. Si no la tuviere podrá operar como interviniente obligado apoyando al litisdenunciante.

En el punto siguiente y dado que vemos una especial vinculación entre las obligaciones solidarias y las denuncias de litis extensivas analizaremos el tema, inclusive con las derivaciones que hacen a las denuncias de litis regresivas.

\section{Denuncia de litis y solidaridad}

En las obligaciones solidarias podemos encontrar pluralidad de sujetos en el campo acreedor, o en el deudor o en ambos. El vínculo de solidaridad se establece con la parte contraria, en tanto entre quienes ocupan el mismo plano de acreedores o deudores solidarios no están unidos entre sí por lazos de solidaridad sino por los que marca la ley civil como consecuencia de aquella (arts.716 y 717 Cód.Civil; arts 840, 841 y concordantes CCCN). La doctrina se pronuncia por la viabilidad de utilizar por el deudor demandado el sistema de la intervención obligada para extender la cosa juzgada al coacreedor no demandante ${ }^{279}$.

Antes de entrar de lleno en el tema, es conveniente tener presente que las normativas sustanciales (arts.715 Cód.Civil ${ }^{280}$ y $832 \mathrm{CCCN}^{281}$ ) se

\footnotetext{
${ }^{279}$.Conf.Fenochietto CarlosEduardo-Arazi Roland.Código...citado T.1 pg 385.Colombo CarlosJ-Kiper Claudio M.Código...citado,T.1,pg.612.,

${ }^{280}$ Art.715 segunda parte "La cosa juzgada recaída en juicio, es invocable por los coacreedores, pero no es oponible a los codeudores que no fueron parte en el juicio.
} 
refieren a la incidencia de la cosa juzgada una vez obtenida, con respecto a quienes no fueron actores o demandados en el juicio en el que se la constituyó. En cambio, las normas procesales referentes a la intervención obligada, establecen los mecanismos aptos para que la cosa juzgada a obtenerse resulte aplicable a los sujetos solidarios ausentes del juicio.

El coacreedor solidario actor,derrotado ante el deudor, no puede citar al coacreedor solidario no demandante pues no tiene reclamo que formularle de regreso por contribución,salvo que se considere que las costas pueden constituir gastos razonables (art.847 c, CCCN ). Podría en cambio practicar una litisdenuncia extensiva para evitar que en tal caso, le pudiera reclamar por los perjuicios que le provocare la derrota atento la posibilidad de que sea invocada por el deudor a quien demandare. Se trata de los supuestos de los artículos 707 Cód.Civil y 846 inc.b CCCN ,por ejemplo, en caso de discutirse la existencia de novación,dado sus efectos extintivos aplicables a todos los acreedores .El coacreedor citado, al tener acción contra el deudor, podrá ingresar como demandante junto al litisdenunciante o no concurrir conservando en ese caso su papel de tercero obligado en virtud de la extensión de la cosa juzgada.

Un deudor solidario demandado puede citar a su codeudor solidario no demandado con miras a una acción de regreso por contribución (arts

Los codeudores pueden invocar la cosa juzgada contra el coacreedor que fue parte en el juicio.

${ }^{281}$ Art.832.La sentencia dictada contra uno de los codeudores no es oponible a los demás, pero éstos pueden invocarla cuando no se funda en circunstancias personales del codeudor demandado.

El deudor no puede oponer a los demás coacreedores la sentencia obtenida contra uno de ellos; pero los coacreedores pueden oponerla al deudor, sin perjuicio de las excepciones personales que éste tenga frente a cada uno de ellos. 
689,716 y 717 Cód.Civil,arts 840 y 841 CCCN) o a practicar una citación extensiva- permitiéndole ser tercero obligado ya que el actor no puede ser forzado a demandarlo ; pero el solidario demandado no podrá citar a un acreedor no demandante pues este tampoco puede ser obligado a demandarle, fuera de que no podría cobrarle ni sería válido el pago que le hiciere (arts. 706 Cód.Civil y $845 \mathrm{CCCN}$ ); tampoco podría serle impuesto un coacreedor al coacredor demandante ${ }^{282}$.Por lo demás,si el objetivo de la denuncia de litis es para el citante obtener un apoyo coadyuvante ,mal puede utilizarse el mecanismo del art.96(94) CPCCN para involucrar a un acreedor. Tendrá que recurrir a una demanda declarativa.

\section{Denuncias de litis excluyentes. Concepto}

Damos el nombre de denuncias de litis excluyentes, a las que son el preludio, bien de posibles reacciones del citado para la reivindicación de su derecho a fin de desplazar a quienes lo pretenden, bien de su autoeliminación como pretendiente si no reacciona. Las denuncias de litis tienen un objetivo excluyente ante situaciones en las que el tercero pueda verse amenazado de perder un derecho propio a manos de las partes originarias y al mismo tiempo, se encuentra en condiciones de atacar la consistencia de la relación demandante-demandado si asumiera la tarea de reivindicarlo. Juegan para aquellos casos en los que se promueve-con efecto de cosa juzgada- el aviso a un tercero al que las partes pueden atribuir la posibilidad de reivindicar el derecho discutido entre actor y

\footnotetext{
${ }^{282}$ Por un lado no lo puede forzar a demandarle; y por otro no puede subrogar al actor en su interés extensivo.
} 
demandado o que se autoatribuye la titularidad del mismo. En este último caso se trata de supuestos de verdaderas jactancias, aunque no generadoras de los ya inexistentes juicios de ese nombre ${ }^{283}$. Según el ya derogado código instrumental para la Capital y territorios nacionales la jactancia es una verdadera acción contra el jactancioso, con un objetivo apuntado a someterlo a la jurisdicción para que ratifique o no sus afirmaciones aun cuando no hubiera juicio abierto sobre el derecho referido por aquél. De allí en más y en el primer caso, debe promover obligadamente una demanda para sustentar el derecho pretendido bajo apercibimiento de caducidad del mismo. Aquí se trata de una mecánica inversa aplicable solo cuando se estuviese desarrollando un proceso cuya sentencia pudiese alcanzar al derecho del tercero.

Como puede verse, la denuncia excluyente está referida a la situación o supuesto clásicamente denominado llamamiento al tercero pretendiente,

${ }^{283}$ Por ejemplo, y sin profundizar en la búsqueda, encontramos que el Código de Procedimientos Civil y Comercial de la Capital y Territorios Nacionales, regulaba el juicio de jactancia en los arts.425 a 432. “Art.425. La acción de jactancia es acordada contra toda persona capaz de ser demandada y que, fuera de juicio, se hubiera atribuido derechos propios a los bienes que constituyen el patrimonio de un tercero.

Art.427. Primera parte "El juez competente que reciba el pedido, ordenará que aquel contra quien se dirige, manifieste si es cierta o no la exposición, aceptando la verdad de lo expuesto en sus puntos principales, o bien negando, bajo juramento la versión que se le atribuye.

Art.428. Si aquél contra el que se dirige la jactancia se negare a hacer la manifestación, la hiciere ambiguamente o reconociere la verdad de lo expuesto, el juez ordenará que dentro de diez días entable la acción que surge de los hechos expuestos, bajo apercibimiento, que, de no hacerlo, caducará todo el derecho pretendido y será condenado en las costas.

Vencidos los diez días sin haberse deducido la acción, la parte podrá pedir la efectividad del apercibimiento" 
claramente diverso del significado por el ingreso voluntario de dicho sujeto. Para admitirla, el juez de la causa analizará en su caso, el valor de la jactancia, que ha de consistir en manifestaciones de cierta contundencia ${ }^{\mathbf{2 8 4}}$.

La denuncia de litis supone entonces la presencia de un sujeto que puede sustentar un derecho de exclusión con respecto al sostenido por el actor, de modo de desplazarlo del juicio frente a la contraparte y pasar a ocupar su lugar. Así, establecer la titularidad del derecho a favor del actor A contra $\mathrm{B}$, significará eliminar la posibilidad de que se la atribuya al citado-demandante $\mathrm{C}$ y a la inversa, aceptar el derecho de $\mathrm{C}$ importa negar el de $\mathrm{A}$, en ambos casos dejando vinculado a $\mathrm{B}$ al crédito del que se trate.

De tal manera y para superar el riesgo de que la cosa juzgada que se logre en el juicio presente no sea oponible al tercero(C), y éste requiera un nuevo juzgamiento frente a quien se alce con la titularidad reconocida en el primer fallo, se posibilita que antes de resolverse el juicio en el que se lo llama, genere por sí una litis planteando una pretensión incompatible con la debatida en el juicio en cuanto a la titularidad del crédito discutido, a la que se acumulará por convergencia. Según vimos Carnelutti entiende que el tercero ingresa en el debate común como coadyuvante del citante idea que rechazamos, pues el reclamante, si no reivindica su derecho no ha de tener ningún interés en apoyar a ninguna de las partes- ni estará legitimado al efecto pues nada tiene que reclamarles ni nada le pueden reclamar- y si demanda, introduce el tema de la legitimación propia al que podrá defender sin correlación alguna con la postura del citante demandado y aun

\footnotetext{
${ }^{284}$ Corresponde citar al tercero si este ,en un juicio de ejecución se atribuye derechos que colisionan con el que invoca el actor en el juicio en el que pide la denuncia de litis (CN.Civil,Sala A ,31/8/76,La Sarita de Villanueva S.A,.c/Mormandi de Noya E.D. 71323
} 
enfrentándola, si tampoco admitiese la procedencia del crédito en cabeza del nuevo demandante .

De tal manera, el tercero, se mantendrá realmente como tal y por ende dentro del espacio de la intervención obligada solo si no se presentara demandando, caso en el que, de todas maneras, será alcanzado por el efecto extensivo de la cosa juzgada ( al respecto nos remitimos al punto $\mathbf{8 6} \mathbf{d}$ ).Por el contrario, si demandara, dejara el rol tecerista produciendo una acumulación de litis, campo ajeno a la intervención obligada y a la posibilidad de actuar coadyuvando que queda diluida en la calidad de reivindicante.

No existe sino una sola clase de denuncias excluyentes que debe por tanto ser separada y distinguida de modalidades a las que se suele atribuir, a nuestro juicio erróneamente, la misma naturaleza. Nos referimos a las citaciones que pueden darse en el pago por consignación o en las ejecuciones prendarias e hipotecarias para la realización de bienes con acreedores embargantes, prendarios e hipotecarios y a las que como se verá, excluimos del espectro de aplicación del art.96 (94) CPCCN

\section{Citaciones de apariencia litisdenuncial excluyente}

Hay ciertas citaciones que tienen por objetivo impulsar a un tercero a realizar actos favorables a sus derechos en tanto vinculados con los que se están discutiendo en un juicio. Empero se diferencian de las denuncias de litis en cuanto no habilitan a la discusión de una cuestión común a la manera del art.96 (94) CPCCN. Tenemos así: 
a) Citaciones por consignación. La consignación es una modalidad de cumplimiento de una obligación de dar, prevista en los arts.756 del Cód.Civil y 904 CCCN, que presenta distintas posibilidades: así, la de la demanda instaurada por el deudor contra el acreedor para dar validez a la oblación según lo establecido por los arts.758, 759 y 760 del Cód.Civil y arts.904, 905, 906 y 907 CCCN. Otra está dada por similar acción dirigida por el deudor contra distintos sujetos que pretendieren ser sus acreedores a fin de cumplir y desligarse del pleito dejándolos discutiendo entre sí la titularidad activa (art 754 inc.4 Cód.Civil). La tercera, modalidad de la anterior, también basada en ese dispositivo sustancial, puede operar cuando en un pleito abierto, si concurren al mismo más de un sujeto invocando condición de acreedor, el deudor cumple con la obligación mediante depósito judicial y pide su extromisión a fin de dejar que tales pretendientes discutan entre sí la titularidad correspondiente. Como variante, el art.2211 Cód.Civil, contempla la consignación a la orden del juez del sucesorio, cuando, fallecido el depositante, sus herederos no se pusieren de acuerdo en recibir el depósito.

En el primero caso, al dirigir la demanda contra un acreedor concreto, el consignante descarta todo propósito de generar un debate que no sea con ese sujeto. La citación por el demandado tampoco es posible pues si rechaza la consignación por sostener que no está legitimado a efectos de recibir lo consignado, no estará planteando una cuestión común al derecho que pudiere tener el tercero desde el momento en que se excluye de tal debate.

En las dos hipótesis restantes nos encontramos fuera del campo asignable a las denuncias de litis del art.96(94) CPCCN en cualquiera de sus posibilidades de aplicación; en efecto: el consignante actor o 
demandado, lejos de buscar promover una discusión común con su obvia participación, consigna para ser extromitido de la causa y alejarse de todo debate.

b) Citaciones en la realización de bienes. Llegado el momento de cumplir forzadamente sentencia de remate o una de condena por una obligación de pagar sumas de dinero, resulta necesario citar directa $\mathrm{o}$ indirectamente a terceros acreedores del ejecutado, para que puedan asumir las actitudes que hagan a sus derechos. (arts. 563(573) inc.5 y 565(575) CPCCN ). Es evidente que tal solución muestra su faceta excluyente pues los pone en trance de tener que demandar incidentalmente (tercería de mejor derecho) para discutir el derecho al cobro preferente; sin embargo, no por ello el caso encuadra en los términos del art.96 (94) CPCCN. En primer lugar porque la citación no deviene del interés del citante frente a la presencia de otros acreedores que se autoatribuyen el derecho o la obligación que aquél ostenta, sino del imperativo legal y carga de posibilitar una ejecución acorde con el orden de prioridades y privilegios que puedan sustentar los acreedores para el cobro. Es más, la citación habrá de practicarse aun cuando no se vislumbre el mejor derecho del citado frente al citante, ya que su objetivo es el de la formación de un eventual concurso particular y hasta puede ocurrir que los convocados no vengan a discutir el derecho al cobro prioritario del ejecutante sino a disputar entre sí el remanente. En segundo término, porque a diferencia del sistema de la intervención obligada que exige conexidad de vínculos sustanciales de modo que coincida lo debatido en la relación actordemandado con lo discutible entre uno de ellos y el citado, aquí lo discutible entre citante y terceros hace a una relación totalmente diversa: en efecto, en aquélla será la titularidad del crédito; en ésta la de la prioridad en el cobro en función de la existencia de preminencias y privilegios entre 
distintos acreedores. En tercer lugar porque la cosa juzgada que menciona el art. 98(96) CPCCN es la que se forma para la relación citante-contraparte en cuanto trasciende a la relación citante-tercero; en cambio en la citación de embargantes e inhibientes, la que pudiera resultar hará a la relación entre estos últimos y el citante sin que vaya a tener incidencia sobre el vínculo que motivó el juicio.

También pueden considerarse situaciones especiales con respecto a las ejecuciones hipotecarias: nos referimos al tercer poseedor y al tercer adquirente. (arts.3162 a 3186 Cód.Civil ) siendo el primero el adquirente del bien hipotecado que no haya asumido el crédito (art.2199 CCCN) y el segundo, el comprador que así lo hubiese hecho (art.2200 CCCN).A ello puede agregarse el propietario que ha dado en garantía su inmueble, salvo que fuera fiador. Sin perjuicio de la posibilidad de que tales sujetos participen voluntariamente en la ejecución hipotecaria del bien, los mismos no pueden hacerlo por citaciones derivadas del art.96 (94) CPCCN. En efecto, lejos de ser terceros con posibilidad de generar intervención obligada, no serán sino demandados en el momento en que la normativa permita que el acreedor hipotecario los incluya en sus pretensiones de cobro para el caso del tercer poseedor (arts.3162,3163 Cód.Civil y 588( 598) y 589 (599) inc. $2^{\circ} \mathrm{CPCCN}$ ), o resulte ejecutable de acuerdo a la calidad de deudor del crédito (tercer adquirente).

Como consecuencia de la facultad del acreedor de dirigir su ejecución contra cualquiera de los bienes hipotecados o todos simultáneamente (art.3114 Cód.Civil) el tercer poseedor del inmueble elegido, de haber otros terceros poseedores de otros inmuebles hipotecados, 
(hipótesis del art.3171 Cód.Civil; art.2202 c) CCCN) ${ }^{285}$ puede convocarlos. Pensamos que los dispositivos mencionados habilitan a promover una litisdenuncia regresiva que le permita, luego de dar a los citados la oportunidad de intervenir, reclamarles por contribución. El art.2202 CCCN indica con mayor claridad que el 3171 Cod.Civil, la posibilidad de que la condena se practique en la misma ejecución, luego de haberse satisfecho la acreencia hipotecaria.

\section{Citación de sub inquilinos y otros ocupantes}

En los juicios de desalojo de inmuebles, el art. 679(681) CPCCN impone a las partes la denuncia de sub locatario u otros ocupantes; existiendo,el actor deberá demandarlos. Aparte, el notificador comunicará la demanda a todo ocupante que encuentre aun cuando no haya sido denunciado, haciéndoles conocer la carga de defenderse ante el efecto de cosa juzgada que la sentencia habrá de producir. Así quedarán constituidos

\footnotetext{
${ }^{285}$ Art.3171 Cód.Civil. El tercer poseedor, si se opone al pago o al abandono el inmueble, está autorizado para hacer citar al juicio a los terceros poseedores de otros inmuebles hipotecados al mismo crédito; con el fin de hacerles condenar por vía de indemnización, a contribuir al pago de la deuda en proporción al valor de los inmuebles que cada uno poseyere.
}

Art.2202 CCCN. "Ejecutada la garantía o satisfecho el pago de la duda garantizada, el propietario no deudor tiene derecho a :

c) En el caso de existir otros bienes afectados a derechos reales de garantía en beneficio de la misma deuda, hacer citar a sus titulares al proceso de ejecución o promover uno distinto, a fin de obtener contra ellos la condenación por la proporción que les corresponde soportar según lo que se haya acordado o, subsidiariamente, por la que resulta del valor de cada uno de los bienes gravados." 
en demandados, al igual que si, por el propio accionante se hubiese ampliado la acción contra los denunciados (art. 682(684) CPCCN); de tal maneras, no se trata de caso encuadrable en el art.96(94) CPCCN, pues tampoco hay aquí terceros que puedan reivindicar el título del actor para recuperar el bien sino, lisa y llanamente,demandados. Este criterio no es sino el expuesto por la Corte Suprema en la causa Barrio Juniors SRL c/Marich Santiago,20/8/96, LL 1997-C-501,tal como lo hace notar Palacio 286.

\section{SECCION TERCERA}

PRESUPUESTOS DE LA DENUNCIA DE LITIS

\section{Enunciación}

Para que sea posible admitir la denuncia de litis y con ello decretar judicialmente la citación para intervención obligada, se hace necesario que concurran ciertos presupuestos .Estos pueden ser subjetivos u objetivos. Los primeros, hacen a las calidades que ha de reunir el litisdenunciante para poder requerir y obtener la citación; a saber: 1) interés y 2) legitimación. Los segundos se vinculan con factores externos al solicitante, relativos al "espacio" procesal en el que puede tener anclaje la relación citante-citado. Así será menester que 1) exista un proceso abierto o un pedido de prueba anticipada 2) una pretensión adecuada para permitir la

\footnotetext{
${ }^{286}$ Palacio Lino E.Un caso anómalo de intervención de terceros. LL 199 7-C-500.
} 
intervención. 3) que el proceso, por sus características, admita la litisdenuncia 4) que medie coherencia citatoria 5) que la conexidad presente determinadas características en su estructura 6) que tal conexidad produzca comunidad de debate.

\section{Interés}

Varios son los puntos de vista sustentados por la doctrina acerca de cuál es el interés que impulsa a producir la denuncia de litis. Así, se lo ha fincado en un fin de beneficio para el citado, por considerarse que deriva de la necesidad de que participe de un proceso en el que se discuten cuestiones que afectan un interés que le es propio.De tal manera citándolo se asegura su derecho de defensa posibilitando su ingresoen la discusión común ${ }^{287}$.

También en la conveniencia de extender los efectos de la cosa juzgada a todos los interesados en una determinada relación o estado jurídico, y excitar o facilitar la intervención del tercero en el pleito en el que se lo 1 lama ${ }^{288}$; igualmente, si bien apuntada a las acciones regresivas,

\footnotetext{
287 "La citación de terceros reconoce su fundamento en la necesidad de que éstos participen en un proceso, en el cual se podrán discutir cuestiones que afectan a intereses que le son propios. Y sin perjuicio de ello, su régimen cabe aplicarlo no sólo cuando le es común al tercero, de manera que podría haber asumido inicialmente la posición de litispendencia del actor o del demandado, sino especialmente en aquellos supuestos en que la parte, en caso de ser vencida, se encuentre habilitada para intentar una pretensión de regreso contra el tercero" (CN Civ.Sala C,30/9/96,Alta Tecnología Médica S.A.c/Ocampo Yaber.LL del 22/11/96 fallo 30.074 S.)

${ }^{288}$ Chiovenda Giuseppe. Obra citada,T.II,V.II pg.643
} 
en el objetivo de evitar que el demandado pueda argüir la excepción de defensa negligente, mali defensa o incluso la exceptio doli .

Es claro que el derecho de defensa del tercero no está en juego si no se lo llama, pues en esas condiciones la cosa juzgada no podrá alcanzarle.

No puede imponerse al particular la necesidad de custodiar al máximo la eficacia jurisdiccional para que pueda solucionarse de una sola vez todas las facetas e intereses del conflicto. Tal objetivo hace, fundamentalmente, al oficio judicial.

Por tanto no queda sino considerar que la denuncia del art.96 (94) CPCCN está motorizada exclusivamente por el interés del citante. Tal extremo es, naturalmente distinto del contexto normativo creado para la consideración de tal interés, elaborado de modo de asegurar el derecho de defensa de los partícipes, la armonía del proceso y la eficacia jurisdiccional.

El interés del citante, en toda denuncia de litis, radica fundamentalmente en la extensión de la cosa juzgada.

Además,en las extensivas ,según lo ya expresado,se trata de preservarsede la imputación de una mali defensa.

En las denuncias de litis regresivas se agrega también un interés preventivo, eventual, apuntado a obtener un resguardo importante ante la posibilidad de que el tercero cuando sea devenido en demandado, frustre el logro de cosa juzgada oponiendo la exceptio mali defensa. El denunciante, para evitarlo, pone al tercero en aptitud de concurrir para defenderlo con lo cual no podrá luego -habiendo desaprovechado la oportunidad que se le brinda- imputarle la responsabilidad de su derrota ya que pudo evitarla por sí mismo, en tanto no se trate ,claro está, de oponer defensas personales . 
Es decir que el interés básico del citante no es producir su defensa por parte del citado. En efecto, en la evicción relativizamos la importancia de la asunción de defensa por el garante según el caso del que se tratare y teniéndose en cuenta la posibilidad del saneamiento como corrección del derecho transmitido. Si ello es así, menor ha de ser el interés del litisdenunciane en la defensa por parte del citado cuando, como ocurre en la citación regresiva vinculada a la garantía simple, no hay derecho transmitido, ni saneamiento de títulos, ni asunción de defensa por parte del tercero que le permita ser sustituído. Menor también, si se piensa en la posibilidad de discrepancias entre el litisdenunciante y el tercero.

Pero debe advertirse la existencia de otro interés de no menor trascendencia que el demandado citante pueda hacer valer siempre que el actor tenga acción contra el citado; se trata de la posibilidad de reducir o hacer desaparecer su propia responsabilidad ante el demandante, presentándole como argumento defensivo, un real responsable al que pueda demandar ,incluso quizá al tiempo que desiste de la acción contra el litisddenunciante.

En las excluyentes, el denunciante -si es actor-, buscará ponerse a cubierto de cualquier reclamo que un tercero pretendiente puede hacerle en el futuro con respecto al bien o al derecho en juego; paralelamente apunta a superar los obstáculos que el demandado pueda oponer al progreso de la demanda, basándose en la existencia de un posible mejor derecho en cabeza de un tercero. Si la citación proviniese del demandado, es claro que con ella buscará clarificar su situación para no verse envuelto en un ulterior reclamo del tercero si pagare a quien se lo está reclamando. 


\section{Legitimación para denunciar}

a) Partes originarias. Tal como lo señala el art.96(94) CPCCN ,y como regla y principio general, actor y demandado se encuentran habilitados para promover la denuncia de litis. Es decir que según esa norma, tiene que tratarse de sujetos con calidad de parte originaria.

Dada su condición de demandado, el reconvenido está en condiciones de promover la citación de un tercero, pero en tal caso, el llamamiento debe referirse a la controversia generada en la reconvención y no a la de la demanda si es que por sus respectivos objetos pueden establecerse diferencias; de lo contrario se estaría dando al actor una nueva y extemporánea oportunidad de producir la citación ${ }^{289}$.

En caso de litisconsorcio inicial cualquiera de sus integrantes podrá promover el aviso al tercero. Resulta posible que varios puedan hacerlo con uno o que lo lleven a cabo con respecto a distintos sujetos.

La interpretación literal del art.96(94) CPCCN permite sostener que el actor podría denunciar el litigio tanto a los sujetos que pudieran ocupar su misma posición en la relación jurídica sustancial (acreedores) como a los integrantes de la misma relación pero en el campo opuesto (deudores). Igualmente el demandado podría hacer lo propio con los codeudores y con los coacreedores no demandantes.

\footnotetext{
${ }^{289}$ CN Civ, Sala C,22/10/75.Pozio Juan L.c/Porto Celestino E.D. 66-526. El tribunal observó de todos modos que el actor -reconvenido pretendía el llamamiento de un sujeto que no podía ser tercero pues no había en su contra acción de regreso factible, sino que se trataba en realidad de un nuevo demandado.
} 
Sin embargo, ya la doctrina italiana advirtió la existencia de diferencias (Ver punto 18 y opinión de Chiovenda) en orden al ejercicio concreto de la posibilidad de litisdenunciar que limita al actor a hacerlo con sus colegitimados activos pero permite al demandado llamar a los colegitimados propios y a los del contrario. En la doctrina argentina encontramos reflejada esa línea de pensamiento señalando la amplitud de las posibilidades del accionado que llegan hasta poder llamar al tercero pretendiente $^{290}$ pero también que a la inversa, el demandado no tiene aptitud para citar a sus colegitimados, salvo especial disposición de las leyes de fondo, pues no puede imponer un demandado al actor ${ }^{291}$.

Pensamos que la posibilidad de litisdenunciar no puede estar separada del requisito de interés asignable a cada sujeto procesal y de la necesidad de ajustarse a la finalidad y a la configuración que la ley hace de la intervención obligada. En tal sentido, corresponderá tener en cuenta las categorías en las que hemos dividido la figura que nos ocupa y ver cuál es el alcance de la facultad de denunciar de la que dispone cada una de las partes originarias según la clase de denuncia de la que se trate.

b) Denuncias de litis regresivas. Para requerir la denuncia al tercero, el actor deberá ser titular activo de una relación jurídica que le permita resarcirse de aquél por el desembolso que tuvo que afrontar frente a la contraparte. ${ }^{292}$.

\footnotetext{
${ }^{290}$ Martínez Hernán J.Obra citada pgs.284 y 285

${ }^{291}$ Palacio Lino E. Derecho... citado,T.III,pgs.216 y 217

${ }^{292}$ CN Com.Sala C.2/9/77 Escolta SRL c/Telam S.A. LL.1978-A-522;CN Civ.Sala E 11/8/75.Artifort S.R.L. c/Fenández León. y otros. E.D.66-324
} 
Tiene dicho la doctrina, y así lo señalamos antes, que la denuncia de litis está pensada como herramienta de la demandada, ya que en manos del actor producirá "normalmente una extensión de la demanda"293. Es claro que si bien el actor no cita sino demanda, ello no significa que no tenga espacio para litisdenunciar, como vimos que ocurre con las acciones regresivas por contribución con respecto a los co-acreedores no demandantes .

En cuanto al demandado, podrá citar si media una acción regresiva por contribución con respecto al codemandado; éste no sería demandado sino coadyuvante obligado del litisdenunciante.

c) Denuncias de litis exensivas. Si se tratare de denuncias de litis extensivas, el litisdenunciante, cualquiera sea su posición en el juicio ,puede hacer citar al titular o titulares del bien que gestiona.

d) Denuncias de litis excluyentes. Como principio general diremos que las denuncias de litis excluyentes, pueden ser instada por cualquiera de las partes originarias. Cada una de ellas puede tener interés en avisar a sujetos distintos, pero también puede darse que ambas partes coincidan en litisdenunciar a la misma persona: el actor por dirimir la cuestión con quien pretenda ser acreedor de su deudor por la obligación de la que se trate; el demandado con quien se atribuya el derecho invocado por el actor para demandarlo, si de ello puede resultar la determinación de la verdadera titularidad jurídica de aquello que se discute .Sin embargo, no es fácil

\footnotetext{
${ }^{293}$ Satta Salvatore. Obra citada,T.I, pg.156. Igual reflexión formula Serra Domínguez (Serra Domínguez Manuel. Obra citada, pg.233 nota 98) y Martínez Hernán J. pero separando el caso del tercero pretendiente Obra y tomo citados, pg.334. Esta idea también aparece en nuestra jurisprudencia: CN Com. Sala A.26/5/76 Constructora Argentina de Propiedad Horizontal, quiebra. E.D.71-418; id Sala C 15/3/79 Bodegas y Viñedos Giol c/Gutierrez y Repetto E.D.121-338 nº67
} 
concebir que el actor pueda promover la citación del tercero que se autoatribuya la titularidad que está sustentando. Con ello estará debilitando su propia legitimación al tiempo que facilita la acción de su eventual contrincante. Sin embargo teóricamente estará habilitado para hacerlo si quiere dar una mayor seguridad a su derecho, desbaratando así la posibilidad de juicios futuros proveniente del citado. Es cierto que podría promover una acción declarativa contra el tercero destinada a acumularse al juicio en el que se produce la llamada, pero nos parece una solución poco práctica si puede, con solo convocarlo, trasladar la iniciativa al eventual pretendiente y liberarse de todo engorro.

El demandado resultará el principal interesado en el llamamiento para no quedar expuesto al reclamo del tercero si llegara a satisfacer el requerimiento de quien no es el verdadero titular.

\section{Denuncia de litis por terceros}

\section{a) Denuncias de litis regresiva por responsabilidad en general.} Con respecto a la viabilidad de una denuncia a instancias del propio tercero, la jurisprudencia entiende como regla básica, que no corresponde otorgarle dicha facultad pues el art.96(94) CPCCN solo la concede a actor $\mathrm{y}_{\text {demandado }}{ }^{294}$.En esa misma línea, Kenny sostiene la improcedencia del

\footnotetext{
294. CN Trab, Sala VIII 31/8/94, Vallejos Ricardo J.c/Entel y otro D.T.1995-A,673. Id. Sala III,18/10/2005, Albornoz Diego y otros c/Pistrelli, Henry y asociados, LL 2006-A691; C.Nac.Cont.Adm.Fed. Sala 5a ,5/3/2013, Cuccarese ,Nicolás y otros c/Gobierno de la Ciudad de Buenos Aires, JA Boletín del 17/3/2013,JA 2013-III-; Cam.1ª CC San Nicolás 19/12/95 Andrada Hugo V.y otros c/Diario El Norte s/daños y perjuicios. E.D.169-432. Se trató de un juicio en el que ,por estar imputada la policía local se
} 
llamamiento señalando el peligro de que se desate una cadena de litisdenuncias con grave perjuicio en la demora para los litigantes originarios; propicia como solución el planteamiento de una pretensión del citado contra el otro tercero, con la consiguiente acumulación. Sostiene que el art.110(112) CPCCN no puede ser tomado analógicamente pues a diferencia de las situaciones del art.94(96) allí se da una carga cuyo incumplimiento puede hacer perder la pretensión regresiva contra el garante ${ }^{295}$.

En sentido contrario, deben recordarse las codificaciones que admiten expresamente la citación por el tercero, si bien ha de tenerse en cuenta que se trata de sistemas que dan tratamiento único a la intervención obligada que denominamos genérica y a la intervención obligada por garantía de evicción ${ }^{296}$.

El art.112(110) CPCCN, no es de aplicación analógica y no porque la citación sea una carga, sino porque se refiere a un supuesto distinto del que hace a la intervención obligada genérica. En efecto: si bien en la evicción la denuncia de litis que se da en favor del interés del demandado debe ser soportada por el actor, en la intervención genérica el demandante no está obligado a hacer lo propio con la intervención del resto de los sujetos que quedan fuera de ese interés, ni a admitir discusiones distintas de la básica que lo separa de su contrario.

dispuso la citación como tercero de la Fiscalía de Estado de la Provincia, a la que a su vez se le denegó la citación del Estado Nacional

${ }^{295}$ Kenny Héctor Eduardo, Obra citada,pg. 121

${ }^{296}$ Art.25 IV del CPC de Mendoza, el art.80 última parte del Proyecto Fernández y en la legislación extranjera la $2^{\mathrm{a}}$ parte del pgfo 72 ZPO Alemania, los arts 166 y 167 CPCC Italia o en el art.54 última parte CPC Colombia-actual, art.65 parte final CGP. 
Así, el garante de evicción es llamado a debatir con el actor y junto al denunciante la existencia o no de un defecto jurídico en el derecho transmitido; el tercero, cualquiera fuere (transmisor inmediato o mediato) será siempre, el que por ser causante original o por sucesión, fue titular del derecho viciado; por lo tanto, cualquiera de aquéllos ex propietarios, estará debatiendo con el actor la misma cuestión que éste inicialmente pensaba debatir con el demandado: en consecuencia, el ingreso de terceros, si bien pluraliza el número de intervinientes. no altera para nada tema a decidir $\mathrm{y}$ en tal sentido no causa detrimento al sujeto demandante ; cosa similar ocurre si es el propio actor quien llama al garante.

En el caso del art.96(94), la situación difiere fundamentalmente: el primer citado ingresa para discutir con el actor la misma cuestión que éste le planteó al demandado; pero si ese tercero denuncia a otro ya no será para tal objetivo, sino para que se entable otra discusión que no interesa a ninguna de las partes originarias y sobre todo complica al demandante ${ }^{297}$. Ya no será la responsabilidad de $\mathrm{B}$ con respecto a $\mathrm{A}$, con la participación

\footnotetext{
${ }^{297}$ Aún cuando se la pida por quienes aleguen que son cesionarios de los sucesores del vencido (C. $1^{\text {a} B a h i ́ a ~ B l a n c a ~ S a l a ~ I, 15 / 9 / 81 ~ B o h o s l a v s k y ~ J a c o b o ~ c / ~ M a r z a n o ~ F e r n a n d o ~ L L ~}$ XLII A-I 1395,sum.52).
}

Sin embargo, en un caso reciente se admitió la aplicación del art.96(94) CPCCN ante un tercero que pidió la citación de quien le había cedido un crédito de quien ahora lo demandaba.Se trató de lo siguiente: el Señor C.G.E.demandó a C.Fiduciario Financiero S.A. por los daños y perjuicios que le causara al haber informado erróneamente al VERAZ que se trataba de un deudor incobrable. La demandada pidió la citación como tercero del Banco Columbia S.A. que le había proporcionado tal información obtenida a la vez del H.Bank Argentina S.A.que luego le cedió el crédito.El Banco Columbia pidió la citación del H.Bank Argentina. Más que un caso de excepción al sistema del art.96(94) CPCCN nos parece uno de evicción, institución dentro de la que por aplicación del art.112(110),es factible que un tercero cite a otro tercero.(C.Nac.Civil Sala E,21/8/2014,causa G.C.E.c/C.Fiduaciario Financiero S.A. s/daños y perjuicios (JA,boletín del 4/2/2015;2015-I-fasciculo $n^{\circ}$ 5,pg.57) 
del tercero $\mathrm{C}$, sino la de $\mathrm{D}$ con respecto a $\mathrm{C}$, o la de $\mathrm{E}$ con respecto a $\mathrm{D}$, etc, desvirtuándose así el sentido del juicio al introducirse nuevas controversias que dejan de ser comunes con la primera de todas.

Ante la inviabilidad de nuevas citaciones por terceros, éstos aparecen en desigualdad de oportunidades con respecto a los litigantes originarios y en riesgo de que sus respectivas acciones de regreso resulten inviables o por lo menos tengan menores posibilidades de éxito. Es donde resulta el acierto de la solución propuesta por Kenny: el citado, una vez que tuviera que responder al demandado, podrá accionar contra quien considere responsable del pago que tuvo que afrontar y así sucesivamente.

En cuanto a la cosa juzgada de $\mathrm{A}$ contra $\mathrm{B}$ valdrá con respecto a $\mathrm{C}$, pero nunca podrá computarse con respecto a D, E, F etc. ,ya que si se alcanzó contra $\mathrm{B}$ es porque ni $\mathrm{B}$ ni $\mathrm{C}$, pudieron probar ante $\mathrm{A}$, la responsabilidad de $\mathrm{D}$ o de otro tercero, pues en ese caso se hubiera desestimado la demanda .Ello no cierra la posibilidad de que $\mathrm{C}$ en el juicio contra $\mathrm{D}$, pruebe tal responsabilidad y pueda resarcirse de lo que desembolsó ante $\mathrm{B}$, sin que el nuevo fallo altere la cosa juzgada correspondiente a la relación A contra B.(Ver al respecto el punto 86).

b) Denuncias de litis regresivas por contribución. También en ellas, se da la imposibilidad de citación por parte del citado si bien por motivos distintos que los considerados en los casos anteriores. En las citaciones por contribución el tercero citado, en principio, no podrá litisdenunciar ya que en ellas se le estará reclamando exclusivamente el monto de su aporte y por ende no tendrá de quien resarcirse.

c) Denuncias de litis extensivas. El tercero es quien podría demandar al citante por los daños propios sufridos. Los que con motivo de éstos pudiera sufrir otro sujeto, escapan al tema del litigio. 
d) Denuncias de litis excluyentes. El tercero citado no podrá a su vez, llamar al que considere o se jacte de ser titular del derecho pretendido. Desde el punto de vista de su propio interés, una convocatoria en tal sentido debilitaría la fuerza del reclamo propio. Por otra parte, significaría introducir una discusión ajena al interés del denunciante, pues importaría pasar a dilucidar el derecho del citado frente al de otro sujeto y no el del citado frente a quien lo llamare.

\section{Proceso abierto}

a) Principio. Con relación a todas las categorías de litisdenuncias es realmente innecesario señalar que la del art.96(94) CPCCN solamente puede producirse en un proceso abierto, es decir en aquél en el que se hubiese presentado demanda y no se encuentre con sentencia firme. De no haber demanda no puede darse controversia de la que deba deducirse su comunidad con la cuestión definitoria de la relación denunciante-tercero. Tampoco puede llamarse una vez precluída la posibilidad de producir denuncia.

b) Prueba anticipada. Si se tratare de reunir prueba anticipada por parte del eventual accionado en previsión de producirse la demanda, para que la cosa juzgada luego, pueda valer en acción de regreso, habrá que citar al tercero con alcance limitado a tal acto instructorio y siempre y cuando tal prueba haga a la eventual cuestión común. Después de la demanda pero antes del período probatorio, se supone que el tercero estará ya convocado al pleito. 
Si se tratare de denuncia de litis excluyente, el tercero, eventual revindicante, solamente podría requerir prueba anticipada llamando a sus posibles oponentes no por el art.96(94) CPCCN sino por el art.326 CPCCN .

c) Diligencias preparatorias. En materia de diligencias preparatorias pensamos que no corresponde denunciar al tercero para que participe de las mismas como tal; aquéllas, solamente pueden involucrar a eventuales actores o demandados únicos habilitados para proporcionar los datos requeribles. Si se hubiese dado una denuncia excluyente, quien pretendiera plantear su pretensión podrá pedir preparatorias con referencia a sus eventuales demandados, pero por el sistema del art.323 CPCCN .

Tres de los códigos procesales fuente del CPCCN (ver nota 1) admiten que la litisdenuncia pueda producirse por el actor antes de demandar. El código cuyano lo hace dentro del régimen de tratamiento unificado de intervención obligada de terceros y evicción. Los otros dos ordenamientos establecen esa posibilidad con respecto a la evicción y no con referencia a la intervención obligada genérica. Con esa solución, si se cita antes de demandar, se posibilita que convocado y convocante convengan la redacción de una demanda en común o por lo menos en forma coincidente, o bien que el convocado opere desde el vamos asumiendo la defensa; es elemental que el garante, para poder decidir si le corresponde ayudar a su garantizado actor, debe saber qué pretende. De tal manera ese llamamiento, en tanto la demanda no se encuentre presentada, no será sino un acto preparatorio que devendrá en citación válida para provocar los efectos de responsabilidad del citado ante el citante, si venciere el plazo legal y el primero no hubiese presentado la demanda solo o en conjunto según el caso. No nos parece que la solución comentada sea aplicable a los casos de 
intervención obligada genérica en la que no habrá asunción de defensa ni posibilidad de sustitución por parte del tercero (Ver al respecto el punto 10)

d) Mediación. La ley 25.589 , en su art.21 regula la intervención de terceros al trámite de mediación ${ }^{\mathbf{2 9 8}}$. De la actitud del tercero citado, deberá dejarse constancia en el acta, según lo dispone el art.2 inc.c) de la ley, pieza que también deberá llevar la firma del tercero compareciente (art.26).

De la letra legal podría deducirse que la citación a terceros no es posible sino en caso de preverse un futuro juicio con presencia de un litisconsorcio necesario; si bien en ese supuesto no se trataría de llamar a terceros sino a las partes naturales del conflicto, siendo así, la parte final del art.21 resultaría una verdadera incongruencia pues si hay necesidad de la presencia del tercero, mal puede rechazársele si concurre a destiempo pero antes de terminarse la mediación. Salvado ese aspecto, nos parece claro que la ley tiene en cuenta esa posibilidad e impone al mediador una citación oficiosa. Pero estimamos que el artículo mencionado no tiene precisión procesal -ni terminológica- y para tal norma, tercero es una figura genérica que incluye desde posibles intervinientes voluntarios al tiempo de abrirse procesos, hasta pretendientes o eventuales sujetos de intervenciones obligadas;es decir casos en los que el arribo de tales sujetos no es sino conveniente; el mediador ante tal virtualidad, los citará incluso por propia iniciativa. Es claro que no se trata de denuncias de litis sino de meros

\footnotetext{
${ }^{298}$ Art.21.Citación de terceros. Cuando el mediador advirtiere que es necesaria la intervención de un tercero, de oficio o a solicitud de cualquiera de las partes, o por un tercero, en todos los casos con acuerdo de las partes, podrá citarlo a fin de que comparezca a la instancia mediadora. El tercero cuya intervención se requiera debe ser citado en la forma y con los recaudos establecidos para la citación de las partes. Si el tercero incurriere en incomparecencia injustificada no podrá intervenir en la mediación posteriormente
} 
pedidos o iniciativas de convocatorias. Ninguna consecuencia provocará la inasistencia del citado ni quedará alcanzado por el acuerdo al que pudieran llegar los sujetos concurrentes.

\section{Tipos de proceso y pretensiones}

a) Denuncias de litis regresivas. Procesos de conocimiento. Ubicado el art.96(94) en la parte general del CPCCN, Libro Primero, Disposiciones generales, sin duda que la denuncia de litis es aplicable a los procesos de conocimiento-cualquiera sea su clase- dado que son los que admiten en su estructura demanda, excepciones y contestación de demanda. Quedan comprendidos entonces tanto los ordinarios como los sumarios -en casos en que subsistan en las normativas locales- y sumarísimos ${ }^{299} \mathrm{y}$ también los especiales si se ajustan al modelo de los dos anteriores ${ }^{\mathbf{3 0 0}}$, si bien no será procedente en los juicios de alimentos y litisexpensas (arts

${ }^{299}$ CN Civ.Sala E. 21/5/85 García Gomez Miguel,L.L. 1986-A,637 (37004 S); idem Sala C 15/3/94 Marquinez y Perotta c/Municipalidad de Buenos Aires L.L. 1995-C,442 (con nota de Roland Arazi "El tercero adherente simple" que admite que la citación puede darse también en los incidentes; en contra: No cabe citar en los incidentes pues solamente pueden admitir para su dilucidación la presencia de las partes existentes al momento de producirse . CN Civ.Sala C 2/3/93 Balneario Las Toninas c/Goypun S.A. JA 1994-III-322. Cam. Com Sala B 14/4/75 Dicón Difusora Contemporánea c/Louzan Publicidad S.A. E.D. 63-405,n²39;idem 11/11/81 Ratto José L. c/Maro Juan y otro. E.D. $121-343, n^{\circ} 111$.

${ }^{300}$ Kenny Héctor Eduardo, obra citada,pg. 86. 
639(643) y 646(650) CPCCN) en razón de que no son viables las acciones de regreso por contribución ente los distintos legitimados ${ }^{\mathbf{3 0 1}}$.

Sin embargo, la aptitud del proceso de conocimiento no es suficiente para admitir la denuncia de litis si la pretensión no tuviese el sentido patrimonial que hace a una acción de regreso .

b) Procesos ejecutivos. En materia de juicios ejecutivos opera una fuerte tendencia jurisprudencial que niega la posibilidad de denunciar en razón de la inexistencia en su trámite, de excepciones previas y contestación de demanda.A este criterio se opone otra línea de pensamiento $^{302}$.

Como dijimos, la intervención obligada de terceros está prevista entre las disposiciones generales del CPCCN y por ello como regla general sería aplicable a todo juicio. También observamos que los ejecutivos tienen demanda y si bien no está previsto su traslado y contestación, establecen oportunidades para oponer excepciones, que a los fines de la litisdenuncia bien podrían ser equiparadas a los escritos de respuesta de los procesos de conocimiento. Pese a ello nos inclinamos por el primero de los temperamentos señalados pues, en primer lugar, no vemos en las

${ }^{301}$ Cam. Apel CC Rosario Sala I, 16/11/81 Dasso S.Arístides c/The First National Bank of Boston-Banco de Boston-Rep.LL XLII,A-I 1392 sum 25.CNCiv Sala L 30/3/95 Inmobiliaria y Financiera Ltda c/Luchetti Reinaldo J.A.1995-III-síntesis. CN. Com.,Sala A 23/11/93 Guevara Lynch Emma c/Temperley Ernesto E.D.157123;Cam.C. y C. San Martín 26/4/94 González Horacio c/Artix S.A. J.A. 2000-I-84.En la doctrina Kenny Héctor Eduardo.Obra citada,pg.86

En nuestro modo de ver,el art.546 $\mathrm{CCCN}$, establece una citación regresiva por contribución,susceptible de ejecución conforme lo explicado en el punto $\mathbf{1 0 2}$ a.

${ }^{302}$ Para Fenochietto Enrique -Arazi Roland .Código...citado,t.I pg.94 y Fassi-Yañez, Código...citado T.I,pg 533, la convocatoria resultará posible, siempre que se acentúe el criterio restrictivo de admisión 
ejecuciones comunes que la abstracción instrumental permita la existencia de una cuestión común que pueda discutirse con un tercero en tanto éste resulta formalmente ajeno al título. $\mathrm{Si}$ hay varios acreedores indistintamente habilitados para ejecutar, quien tomara en sus manos hacerlo, carece de interés en llamar a los otros pues como titular del crédito asumirá la derrota de forma exclusiva y sin derecho a pedir contribución por las costas a los restantes. Si vencedor, los reclamos de los acreedores deberán llevarse a cabo por medio extracambiario (art.59 Dec.Ley 5965/63).Si el título solo habilitara a una ejecución conjunta, un acreedor no puede iniciarla solo y no vemos viable la citación como medio de forzarlos a litigar, pues de no concurrir, su presencia no queda suplida con la litisdenuncia.

Si se tratare de obligaciones solidarias, habrá que considerar separadamente los casos de solidaridad activa (expresada en el título) y pasiva resultante del sistema cartular. En el primero de esos supuestos, sería académicamente factible la citación de los coacreedores literales para que, cuando se les reclame por las costas en caso de derrota (si pudieran considerarse gastos razonables,art.847 inc c, $\mathrm{CCCN}$ ), no puedan alegar la exceptio mali defensa pues entre ellos no existe acción cambiaria y rigen las disposiciones de las obligaciones solidarias (art.59 del decreto ley $5965 / 63)$.

En cuanto a los deudores solidarios, el ejecutante no puede citarlos sino directamente ejecutarlos, si bien como es sabido, puede elegir contra quién dirigir la ejecución. A su vez y en ese campo rige la solidaridad resultante de la ley (art.51 decreto ley 5965/63). El sistema se completa con las disposiciones de los arts 53 a 56 de ese ordenamiento, de manera que quien hubiese pagado la letra puede resarcirse íntegramente con la acción regresiva cambiaria contra el codeudor que elija y así sucesivamente. Este, 
o los que deban responder en adelante, están en condiciones de alegar todas las defensas que fueran viables contra la ejecución, independientemente de las que hubiese omitido o sustentado el que estuviera ejecutando, de modo que no tiene sentido que el primer ejecutante denuncie por regresiva ya que en el sistema no hay cabida para la mali defensa.

c) Denuncias de litis extensivas. Pueden hacerse en todo tipo de proceso de conocimiento en tanto la pretensión que se quiere evitar tenga sentido patrimonial.

d) Denuncias de litis excluyentes. Puede proceder en todo proceso de conocimiento, pero, quedarían afuera los casos de pretensiones declarativas que tuvieren un objeto no reivindicable por un tercero (ejemplo una declaración de filiación) o significaran el ejercicio de un derecho exclusivo no fungible por otro similar (por ejemplo, el pedido de nulidad formulado por un legitimado al efecto). Algo similar puede decirse de los legitimados para obtener una declaración de incapacidad.

\section{La intervención obligada y los procesos colectivos}

a) Legislación. Sabido es que no existe en la Argentina, una normativa que de manera general y completa regule a los procesos colectivos y específicamente la temática de la intervención de terceros. Será menester entonces buscar elementos útiles en la legislación existente vinculada con derechos homogéneos y difusos: las leyes de defensa del consumidor (ley 24240) y general del ambiente (Ley 25675) en cuanto puedan brindar pautas al efecto. De todos modos, las disposiciones de los códigos procesales resultan supletoriamente aplicables a los procesos 
referidos si bien en la práctica, la utilización de las distintas figuras que componen el espectro de la institución de terceros aparece acotada o de imposible producción, dadas las especiales legitimaciones establecidas para la defensa de aquellos derechos y la naturaleza de los mismos.

La ley 24.240 contempla en su art.52 segunda parte, los procesos individuales de usuarios y consumidores afectados, legitimándolos al afecto, así como a las asociaciones de consumidores, autoridad de aplicación, defensor del pueblo y ministerio público fiscal. Al respecto, ninguna referencia encontramos sobre terceros, pero entendemos que nada impide utilizar la ley procesal en cuanto a intervenciones voluntarias de las previstas en el art.92(90) inc.2 y 93(91) segunda parte CPCCN, por los legitimados activos que no demandaron originariamente. No vemos en cambio supuestos que nos sirvan para sustentar la admisión de coadyuvantes simples en el campo actor, ya que se supone que también se tratará de consumidores habilitados para demandar.

En el ámbito demandado resulta viable la intervención para coadyuvación simple (por ejemplo un fabricante apoyando al vendedor demandado) y en cuanto a la intervención obligada por litisdenuncias regresivas, se perfila claramente en las previsiones del art.52 bis que establece responsabilidades solidarias para toda la cadena de producción o comercialización del producto al que se refiere el conflicto. A la vez, la misma ley, en su art.52 tercera parte, refiere los procesos de defensa de los intereses de incidencia colectiva -naturalmente que de los derivados de la relación de consumo- y con respecto a los cuales se somete a la apreciación judicial la legitimación de las asociaciones de consumidores y usuarios para intervenir como litisconsortes. 
Con respecto a la intervención obligada, tampoco encontramos viable una denuncia de litis excluyente tratándose de bienes de valor colectivo. En cuanto a las intervenciones obligadas regresivas por participación en el campo activo, las consideramos improcedentes dadas las características funcionales autónomas de los legitimados para demandar; en cambio, en el pasivo, resulta de aplicación el mencionado art.52 bis. y sus consecuencias. En lo referente a las citaciones extensivas, el sistema de solidaridades y las características de los procesos productivos y las responsabilidades emergentes de los mismos, las hacen compatibles con el derecho del consumo.

b) Procesos colectivos de creación pretoriana. La Corte Suprema, en el caso Halabbi (Fallos 332:111del 24/2/2009) abrió cauce definitivo a la utilización de las acciones de clase en Argentina ${ }^{303}$. En ellas no encontramos cabida para las intervenciones extensivas y excluyentes dado el bien comprometido por la clase a la que deben pertenecer tanto

\footnotetext{
${ }^{303}$ A nuestro entender y en realidad, no se trató sino de un claro ejemplo de acción popular. Posteriormente, en el caso PADEC c/Swiss Medical Group S.A. sentenciado el 21/8/2013 L.L. 2013-F-447) el alto tribunal, reconoció la legitimación de la actorauna asociación de consumidores-e hizo aplicable el sistema de las acciones de clase a los derechos del consumo en tanto la demanda aparece defendiendo un derecho de incidencia colectiva referente a intereses individuales homogéneos. Nos parece que, esta vez sí, se trató de una verdadera acción de clase.
}

Recientemente la CS recordó resumiéndolos los extremos que debe alcanzar una pretensión para conformar una acción de clase, con especial referencia a la determinación de sus componentes y a su homogeneidad (Causa Asociación Protección de consumidores del Mercado Común del Sur c/Loma Negra Cía Industrial Argentina y otros, fallo del 10/2/2015).Igualmente y al respecto, la trascendencia de ciertos derechos-salud por ejemplo-para la configuración de tales acciones (Asociación Civil para la defensa en el ámbito federal e internacional de derechos c/Instituto Nacional de Servicios Sociales para jubilados y pensionados s/amparo. Recurso de hecho, fallo del $10 / 2 / 2015)$ 
demandantes como terceros. En cambio la intervención obligada por litisdenuncia regresiva es perfectamente aplicable en el campo demandado, en tanto el accionado pretenda resarcirse del tercero.

c) La Corte Suprema en instancia originaria. Es interesante destacar que en la materia el alto tribunal considera que las soluciones procesales han de tener una adecuada elastización para hacerlas útiles frente a la naturaleza de las acciones de protección ambiental ${ }^{304}$. De tal manera puede recurrirse a la casuística para ver sus criterios en materia de intervención obligada $^{305}$.

En una causa, la actora invocó el art.92(90) inc. $2^{\circ} \mathrm{CPCCN}$ para pedir que se cite a varias provincias en las que se encuentran las obras que se denuncian como contaminantes, fundando su requerimiento en las consecuencias dañosas sobre los patrimonios ambientales respectivos, en las funciones locales de constituir y regular el Fondo de Compensación ambiental, y de corresponderle las de relevamiento y ejecución de obras hídricas. El pronunciamiento hizo lugar a la solicitud por la eficacia refleja que puede tener lo que se resuelva en cada una de sus órbitas. No resulta claro el carácter procesal que asignó a los estados. Su mención a la eficacia refleja de la sentencia como justificativo para admitir la citación parece indicar que las vincula con el sistema del art.96(94) CPCCN aun cuando en ese caso la citación debió partir de la demandada en previsión de alguna acción regresiva o bien se debió tener a la actora como extendiendo su demanda contra los que pretende citar. Paralelamente, el tribunal denegó la

\footnotetext{
${ }^{304}$ Fallo del 24/8/2006 Beatriz Mendoza y otros c/Nación Argentina y otros( CS Fallos $329: 3445)$

${ }^{305} \mathrm{La}$ CS se ha pronunciado sobre el tema especialmente en materia de su competencia originaria.
} 
citación pedida por la actora con respecto al Defensor del Pueblo de la Nación, por considerar que no estaba fundada. Tal criterio mereció la disidencia de tres de los integrantes del cuerpo que entendieron que procede llamarlo ya que si bien por el art.30 de la ley 25.675, una vez iniciada la acción por otro legitimado solo está habilitado para operar como tercero en esa causa, la ley no limita tal actuación a una intervención voluntaria, de manera que por sus funciones constitucionales debe admitírsele $\mathrm{e}^{306}$.

Sin embargo, cuando una actora pidió la citación como terceros del Estado Nacional y de varias provincias- aparte de la de UNESCO- el tribunal denegó el pedido de citación del primero, por considerar que la demandante no aportó ninguna justificación al respecto y que para el juego del art.96(94) CPCCN era menester demostrar la existencia de una posible acción de regreso o la existencia de una controversia común ;a ello suma que según deriva del art.96(94) $\mathrm{CPCCN}$, la sentencia que resulte debe ser obligatoria para el tercero y en esas condiciones ser ejecutable en su contra, consecuencias que no advierte al igual que tampoco hace lo propio con una comunidad de controversia que justifique el llamamiento a los estados locales ${ }^{307}$.

En la causa Beatriz Mendoza y otros c/la Nación y otros (Fallos 329:3445), se admitió la intervención pedida por el Defensor del Pueblo, teniéndolo como "tercero interesado y de acuerdo a las disposiciones del art.90 CPCCN como se menciona su función constitucional"; parece claro que entonces se refirió al inc. $2^{\circ}$ de dicho artículo hoy 92. Rechazó en

\footnotetext{
${ }^{306}$ Asociación de Superficiarios de la Patagonia c/Y.P.F. y otros,s/recomposición integral de daños (CS. sentencia del 13/7/2004-Fallos 327:2967)

${ }^{307}$ Assupa c/Provincia de San Juan y otros del 25/9/2007 (Fallos 330:4248)
} 
cambio, el intento del interviniente para ampliar la demanda contra varios municipios, señalándose que su intervención no le posibilita apartarse del alcance de la demanda ya articulada.

En otro juicio la actora demandó a varios sujetos, pero pidió se cite a los legitimados activos (Defensor del Pueblo, Estados Nacional y provinciales) invocando sus deberes de protección del medio ambiente. El tribunal rechazó el requerimiento expresando que la ley 25.675, art.30, no impone, dado el efecto erga omnes, que todos los habilitados para la defensa del medio ambiente deban intervenir para obtener un resultado positivo y señaló que solo se los habilita para participar voluntariamente en el juicio iniciado por otro legitimado. Resaltó que la actora dijo expresamente que no tenía ninguna pretensión que sustentar contra los estados locales y especificó que esa situación marcaba una diferencia con lo resuelto en la causa de Fallos 327:2967 en la que el tribunal admitió citar a tales sujetos. Con ello queda en claro que el alto tribunal no dio a la citación de tercero pedida por la actora significado de demanda contra el citado sino de mero aviso ${ }^{308}$.

\section{Inexistencia de presupuestos}

No solamente se hace necesaria la presencia de pretensiones y tipos de proceso que habiliten el juego de la intervención obligada, sino que aun reunidos esos presupuestos, la denuncia será viable siempre que ante los

\footnotetext{
308 Assupa c/Alianza Petrolera Argentina, y otros s/ daño ambiental del 20/3/2012 (Fallos 335-277)
} 
términos de la pretensión discutida no resulte la inutilidad del pedido por mostrarse la inviabilidad de una acción regresiva ${ }^{309}$; o si se pretendiera utilizar la vía del art.96 (94) CPCCN para finalidades ajenas a su alcance natural $^{310}$.

\begin{abstract}
${ }^{309}$ Así por ejemplo, no procede citar como tercero a la cónyuge de uno de los copropietarios demandados por división de condominio, ya que la relación entre el citante y su esposa, aparte de no ser conexa con la del citante y el actor de manera de poder generar un campo común de discusión, no permite advertir que de aquella situación pueda resultar una regresiva del marido a su consorte (Cám.Civ y Com. Córdoba 10/11/2009 Dragonetti Gabriela c/Crespín Nicolás LL Córdoba 2010-4-320).
\end{abstract}

Es improcedente la citación de la Fiscalía de Estado de la Pcia de Buenos Aires, si el inmueble salió de la propiedad de tal Estado para pasar a la municipalidad demandada (Cam.Ap.CC San Martín,10/5/83,Palomba Pascual c/ Municipalidad de General San Martín.E.D.T.121, pg 346, n 152 .Por la viabilidad de dirigirle una acción regresiva en un pleito seguido contra el Estado por daños y perjuicios por error judicial, procede cita al juez en lo penal que dictó el fallo (S.T.J. Jujuy 2/2/2011 Cruz Ramón c/Estado Provincial. L.L. NOA julio 2011,634Se trató, seguramente de un pedido formulado por el estado demandado). No corresponde que a pedido de la agencia noticiosa demandada sean citados en los términos del art.94 del Cód.Proc. el Estado y los ministros del Poder Ejecutivo, si la demanda resarcitoria se funda en las expresiones propias de un despacho periodístico de aquélla y no en los actos del gobierno sobre los que se informaba"(CN Civ.Sala B.25/4/88 Granada Jorge H.c/Diarios y Noticias S.A.L.L.1988-E-52).

${ }^{310} \mathrm{La}$ facultad de pedir citación en caso de acciones de regreso," no autoriza al citante ni al citado a enredar la pretensión básica debatida entre actora y demandada planteando cuestiones a la que las primera es totalmente ajena, pues la citación prevista en el art.94 del Cód. Procesal no es camino apropiado para introducir en la relación litigiosa principal un pleito distinto entre demandado y tercero, que tiene sus propias vías y oportunidades de definición judicial" (CN Fed.Civil y Com.Sala II 2/12/94 Abrego y Goncalves S.A. c/Tomasello Juan S.A.L.L.1995-C-3). No resulta procedente llamar a los integrantes del Consejo de Administración de un consorcio, para que expliquen las razones del presunto desfasaje al que arriba el dictamen de una auditoría, pues el objetivo resulta ser el de obtener la prestación de testimonios acerca del tema"(CN Civ.Sala D 10/4/97 Consorcio de propietarios Avda Luis M.Campos 1025/27 c/Vlasecchi Liliana. L.L.1997-D-664)" El art.94 CPCCN no puede utilizarse para suplir la ausencia de ofrecimiento de prueba en la contestación de la demanda si se quería demostrar la responsabilidad de un tercero (Cám.Nac.Civil Sala G 7/7/2005 Asprea Guillermo c/Mac Alister LL Rep.LXVI pg. 1450 n ${ }^{\circ} 8$ ).”En una acción promovida con el 


\section{Estructura de la conexidad}

a) Introducción. Para el análisis de la estructura de la conexidad será preciso tener en cuenta la clasificación tripartita de las denuncia de litis con la que nos venimos manejando, ya que según las categorías que hemos formulado pueden variar los elementos componentes.

b) Denuncias de litis regresivas. Según lo pusimos de manifiesto en el punto 42, la viabilidad de la denuncia de litis exige, tratándose de litisdenuncias regresivas, la presencia de dos relaciones sustanciales, una la concerniente a la pretensión actual, es decir aquélla en la que se plantea la denuncia; la otra, la que todavía no está en conflicto susceptible de ser resuelto que, mediante la denuncia, se busca conectar procesalmente con tal pretensión. Resulta entonces claro que, como dijimos, no se trata de incorporar sujetos de la misma relación jurídica sustancial al debate de la

objeto de obtener la eliminación de cierta información publicada en sitios web, debe rechazarse el pedido de citación de los titulares de dichas páginas, pues siendo que no se plantea un reclamo patrimonial, es claro que una eventual acción de regreso resulta inadmisible a la vez que no se explicó cuál sería el vínculo jurídico entre los buscadores de internet accionados y las personas a quienes se pretende citar"CN Fed.Civ.y Com.Sala II,6/4/2014,L.L.2014-D-578. No procede admitir la citación ,art.94 que pide la demandada ,si la misma apuntada a la participación de 233 personas-beneficiarios de un plan de viviendas- no aparece vinculada con el juicio que el actor, profesional arquitecto promovió contra aquélla por cobro de honorarios, en tanto el contrato no se formalizó con ellas sino entre actor y demandada. La citación del art.94 CPPCN, es de aplicación restrictiva y solo debe aplicarse si por sus consecuencias no se desnaturalice el proceso.(CS fallo del 14/5/87 ,Fernández Propato Enrique c/La Fraternidad Soc.del Personal Ferroviario (CS Fallos 310:937) 
pretensión de la que se trate, problemática ajena al ámbito de la intervención obligada ${ }^{311}$.

Encontrada la pluralidad de relaciones sustanciales, habrá que comprobar si realmente pueden ser consideradas conexas, objetivo que podrá lograrse cotejando sus elementos componentes. En lo subjetivo y para todo supuesto de conexidad computable, uno de los titulares de la primera de aquellas debe ser el mismo que aparezca en la otra, en tanto que el restante individuo que conforme la segunda, no puede hacer lo propio en la primera, (primera relación: A - B; segunda relación: A o B por un lado y por otro $\mathrm{C}$ como citado; nunca $\mathrm{C}$ en la primera relación).

Llegando a los elementos objetivos, habrá que recordar las diversas posiciones operadas al respecto en la doctrina italiana (ver punto 18), ya que tenemos quien opina que es necesaria la presencia tanto de causa como de objeto, otros que de cualquiera de ellos, y otros más, de alguno determinado. Entre nosotros, Martínez dice que la concurrencia de los dos elementos objetivos es la solución que resulta más acorde con el art.106 CPC Italia, que separa la citación por causa común de la acción de garantía. Piensa en cambio, que como el art. 96(94) CPCCN engloba todos los supuestos de intervención obligada, es factible aceptar como suficiente la presencia de conexidad de un solo elemento (conexidad simple) pues ello

\footnotetext{
311 Para que la convocatoria del tercero "sea pertinente, constituye un recaudo indispensable la existencia de una comunidad de controversia. Los caracteres o elementos de una controversia común son los siguientes: a) una relación jurídica existente entre el tercero y una de las partes ,o bien entre aquél con las dos partes y que tal relación sea conexa y no idéntica con la relación jurídica debatida en el proceso y b) que en virtud de esa conexidad, los elementos objetivos de la pretensión promovida por el actor contra el demandado y que son el objeto y la causa (o de objeto o causa) puedan servir de fundamento de otro proceso frente al tercero o por parte de éste..."(C.N. Federal Civil y Comercial, Sala $3^{\text {a }}$ 18/2/2005, Ramirez Isabel y otros c/Sanatorio San José y otros LL 2005-B-237).
} 
es lo que caracteriza normalmente a las pretensiones de garantía. De tal manera, basta con que se encuentre presente la comunidad de causa entre ambas relaciones para que aparezca la conexidad que justifica el 1lamamiento. ${ }^{312}$ Nos dice Martínez que, "A modo de resumen entonces, creemos que la esencia de la comunidad de causa que sirve de presupuesto de hecho a la intervención obligada de terceros, está dada por el vínculo de conexidad objetiva o causal entre la relación jurídica controvertida y otra (conexa) cuyos sujetos son, respectivamente, una de las partes del proceso principal y el tercero citado"313. Kenny descarta la conexidad por el objeto como un valor determinante ya que lo considera un elemento indirecto de segundo grado, derivación del factor causal; por el contrario ve en éste lo esencial para conformar aquel vínculo ${ }^{314}$.

Observada las denuncias de litis regresivas, vemos que hacen a eventuales pretensiones cuyos objetos serán obtener la restitución dineraria de lo desembolsado por el citante, es decir prestaciones de la misma naturaleza que la que dicho sujeto tuvo que soportar pero con sus correspondientes identidades de modo de no ser confundibles. No es la misma, aunque sea de igual monto y naturaleza, la indemnización que $\mathrm{B}$, demandado perdedor paga a $\mathrm{A}$ demandante, que la que $\mathrm{B}$ habrá de perseguir para ser oblada por C. Por tanto, la conexidad de las relaciones sustanciales no puede buscarse en los objetos, sino en el elemento causal. Ahora bien: en éste, lo fáctico de la relación en crisis deberá estar necesariamente presente en la relación citante-citado ( la actividad dañosa de $\mathrm{B}$ con respecto a $\mathrm{A}$ deberá computarse en la relación de $\mathrm{B}$ con $\mathrm{C}$.) sin

\footnotetext{
${ }^{312}$ Martínez Hernán .Obra citada,pg.278

${ }^{313}$ Martínez Hernán J. Obra citada,pg.281

${ }^{314}$ Kenny Héctor E. Obra citada,pg.32
} 
perjuicio de que puedan darse otros acontecimientos propios de ésta, pero que solamente tendrán trascendencia dentro del contexto brindado por los primeros; así por ejemplo, la relación litisdenunciante-citado deberá incorporar el hecho del pago operado por el perdedor, circunstancia inexistente al tiempo de dilucidarse la pretensión en la que ordenó la citación. La vertiente jurídica nunca podrá ser la misma, pues el eventual actor regresivo no está amparado por el mismo derecho que cobijó a su demandante sino por el que resulta de su desembolso ante dicho sujeto 315

Entonces, en las denuncias regresivas, para que se produzca la conexidad que las justifica, deberán encontrarse en las relaciones sustanciales los mismos elementos semicausales fácticos; en tanto no podrán ser iguales los semicausales jurídicos ni los objetos ${ }^{316}$.

c) Denuncias de litis extensivas. El panorama no cambia en las denuncias de litis extensivas . Como en las regresivas, causas jurídicas y objetos serán diversos, pero el aspecto fáctico de la causa es el mismo en ambas relaciones: la deficiente conducción de la defensa del derecho que motivará el detrimento del derecho del gestionado y su posibilidad de resarcimiento frente al gestor.

\footnotetext{
315 Por ejemplo, el fiador deberá oblar en virtud del contrato de fianza (art.1986 Cód.Civil), pero su derecho contra el afianzado deriva de la subrogación del art.2029 Cód.Civil; B, demandado como deudor solidario paga a A acreedor de esa naturaleza, pero B podrá resarcirse de los demás deudores por la obligación de contribución que la ley impone a su favor (arts 689 y 717 Cód.Civil).

${ }^{316}$ Aclaramos que en nuestro entender, la causa de la pretensión no es una entidad homogénea sino que se integra por dos elementos a los que denominamos semicausales: uno el fáctico: los hechos del conflicto ,y otro el jurídico, es decir la manera en la que el derecho los considera.
} 
d) Denuncias de litis excluyentes. En las denuncias excluyentes, el elemento causal nunca podrá ser el mismo, pues los hechos y el derecho que hacen a cada relación conexa han de ser distintos; por ejemplo, A en virtud de un boleto de compraventa, demanda a B por escrituración y $\mathrm{B}$ pide citar a $C$ que sabe cuenta también con un boleto que puede oponer al de A. La causa de la relación sustancial A con B, no es la misma que la de la relación sustancial $\mathrm{B}$ con $\mathrm{C}$, pues deben computarse dos operaciones distintas de las que resultan derechos diversos. Véase que si en ambas la causa fuese única, el tercero no sería tal, sino sujeto de la misma relación jurídica sustancial; en ese carácter no podría ser citado sino demandado o demandante. Por ende, ambas relaciones, traducidas ya en sendas pretensiones han de interferirse en la existencia de un mismo bien que cada una reivindica para quien las sustente (A reclama a B por la entrega del mismo bien que $\mathrm{C}$ ha de reclamar a $\mathrm{B}$ ). El elemento común a ambas relaciones es entonces el objeto. No obsta a ello la idea de Kenny pues, si como el mismo lo dice, el objeto deriva de la causa pero no se identifica con ella, quiere decir que tiene identidad propia y resultará imposible no computarlo pues nada se ganaría con una causa común si no tuviera como resultante el logro de tal elemento.

\section{Comunidad de controversia}

a) Introducción. La conexidad referida en el punto anterior, sirve de presupuesto para la aplicación del art.96(94) CPCCN, pero éste impone la presencia de otro elemento que debe diferenciarse del anterior. En efecto, la conexidad es una virtud de las relaciones sustanciales en tanto que la “controversia común", es un elemento de la pretensión discutida al que se 
vislumbra como factor similar en la que pudiera plantearse. Así, puede haber conexidad y no darse "controversia", pero, a los fines de la intervención obligada, no puede haber controversia sin conexidad subyacente.

El concepto de "controversia común" está especialmente mencionado en el art.96(94) $\mathrm{CPCCN}^{317}$ aún cuando en el derecho procesal argentino otros códigos no lo utilizan no obstante referirse a la misma figura. Así el CPCC de Santa Fe (art.306) justifica el llamamiento cuando "la relación en litigio fuera presupuesto de una obligación del tercero para con una de las partes”. Martínez sostiene la filiación germánica de ese dispositivo, al que considera derivación del pgfo 72 de la ZPO, pues afirma la poca distancia práctica existente entre el criterio de la ley procesal nacional y la de esa provincia $^{318}$. Tampoco el CPC de Mendoza utiliza la expresión del CPCCN, sino que se refiere al derecho a pedir la defensa o garantía del tercero. El CPCC Tierra del Fuego contiene en su art.103 una fórmula de tal amplitud que permite su aplicación a todos los objetivos citatorios. Por otra parte, pensamos que el concepto de "comunidad de causa" del art.106 CPC de Italia, no es exactamente igual al de "controversia común" de nuestro derecho; aquél se vincula con la posibilidad de acumulación de litis

\footnotetext{
${ }^{317}$ En esa línea,art.79 CPC Jujuy,art.145 CPCC de La Rioja y los códigos provinciales que siguen el modelo del CPCCN, incluidos los CPCC de posterior factura

${ }^{318}$ Martínez Hernán J. Obra citada, pgs.281. Es cierto, dado que si se llama al tercero porque la relación debatida es presupuesto de la que vaya a involucrarlo, se está indicando que la primera conlleva la misma controversia que la segunda. Sin embargo, nos parece que la fórmula de la ley italiana da para incluir en sus términos a las cuestiones comunes generadoras de todo tipo de litisdenuncias comprendidas en el fenómeno de la intervención obligada, en tanto que la letra de la ley santafecinasiguiendo a la norma alemana- solamente apunta a los supuestos de denuncias regresivas.
} 
y el dictado de una sentencia que resuelva todo; éste es ajeno a tal solución y solo tiene en cuenta la identidad de debate para servir a causas sucesivas.

Se ha propiciado como expresión correcta en lugar de "controversia común" (discusión) la de "conflicto común" (colisión de intereses) ${ }^{319}$. Pensamos que el conflicto de A contra B no tiene nada en común con el de A o B con C (tercero citado) pues muestran raíces y objetos distintos; en cambio, las pretensiones involucradas (una real y otra potencial) presentan una cuestión común a discutir (la responsabilidad del denunciante en el caso de las citaciones regresivas; la titularidad activa del crédito en el de las excluyentes) que genera o podrá generar controversia. De ahí que nos parezca adecuado, utilizar los propios términos de la ley.La controversia común,es,por otra parte,la que se suscita con referencia a la "cuestión común",ámbito litigioso que tiene que resolverse en la causa presente,y que no es otro que el que tendría que resolverse en la causa futura.

¿Qué inteligencia debe darse a los términos" controversia común" del art.96(94) CPCCN ${ }^{320}$. Para responder al interrogante formulado debe recordarse que hay controversia común con respecto a los litisconsortes necesarios ya que vienen a participar de la misma discusión con la contraparte; la hay con relación a los litisconsortes iniciales entre si, en cuanto se enfrentan con sus oponentes por el mismo motivo ; también se da

\footnotetext{
${ }^{319}$ Gonzales Atilio Carlos. La intervención voluntaria de terceros en el proceso., pgs 92 y 93.Abaco.Buenos Aires.1994

${ }^{320}$ Kenny así define: "En razón de tales consideraciones estimo que habrá controversia común cuando se entiende que la eventual decisión judicial que resuelva sobre la relación o situación jurídica planteada en el proceso y que constituya la causa de la pretensión, pueda de alguna manera afectar, rozar, alterar, gravitar o comprometer la relación o situación jurídica extracontenciosa existente entre una de las partes y el tercero" (Kenny Héctor Eduardo, Obra citada, pg.33).
} 
entre coadyuvante simple y coadyuvado. Esa multiplicidad de uso, nos permite afirmar que el concepto no puede ser tomado en abstracto, sino en su correlación con los demás presupuestos que marca la ley de manera que la controversia común del art.96(94) $\mathrm{CPCCN}$, debe diferenciarse de los otros supuestos que pueden obedecer a igual denominación, para quedar limitada a los casos en los que por existencia de relaciones sustanciales conexas, puede preverse una acción de regreso, una mera extensión de la cosa juzgada o una reacción excluyente por parte del citado .

Precisamente y para salvaguardar la eficacia de la cosa juzgada- ya que si se juzgara dos veces la misma cuestión bien podrían darse pronunciamientos contradictorios con el consiguiente escándalo jurídico- el orden normativo, junto con el principio de la extensión de la cosa juzgada aun en caso de incomparecencia, genera soluciones acordes con la necesidad de evitar aquél resultado disvalioso.

Como pueden darse variantes en la modalidad de intervención según el tipo de denuncia de litis del que se trate, nos remitimos al análisis del tema referenciándolo según las categorías en las que la dividiéramos.

b)Denuncia de litis regresiva. Con relación a todas las denuncias regresivas, la controversia común es la que, dada la conexidad de relaciones sustanciales, tiene que ser resuelta en la causa en que se produce la citación (es decir entre A y B) para poder hacerla valer en la que se sustentaría eventualmente entre sujetos parcialmente diversos (A con $\mathrm{C}$ o B con C). Lo notable es que el conflicto correspondiente a la segunda de tales relaciones (la de $\mathrm{A}$ o $\mathrm{B}$ con $\mathrm{C}$ ) no tendrá que ser resuelto en el juicio abierto, sino en el que podrá suscitarse como consecuencia de la derrota de la parte que denuncia la litis al tercero y luego de cumplirse la condena respectiva. 
Así, vemos que la controversia común no es otra que la que suscita la determinación fáctica y jurídica de la responsabilidad del citante frente a la contraparte y de la existencia de los hechos que la justifican; dicho tema pertenece tanto a la relación procesal entre estos dos últimos sujetos como a la que vinculará a denunciante con citado, ya que la condena al primero, será el presupuesto ineludible del juicio de regreso. Con ese panorama, y para evitar que el tercero $\mathrm{C}$, cuando sea demandado por A o por B cuestione el valor de la cosa juzgada que se esgrime como presupuesto de la acción en su contra, $\mathrm{C}$ será llamado a integrarse en la litis entre A y B, para discutir con ellos, no la responsabilidad del citado frente a alguno de estos, sino la responsabilidad correspondiente a la relación entre aquéllos sujetos (A-B).

c) Denuncias de litis extensivas. Como en el caso de las regresivas, la controversia común es la que se lleva adelante en el juicio actual con miras a tenerse por válida para el juicio futuro.

d) Denuncias de litis excluyentes. En las denuncias excluyentes, la controversia común es meramente eventual, pues no se dará si no hay reacción del tercero citado. Sin embargo como es la misma que hubiera tenido que discutirse si demandase, la que pudiere resultar entre los litigantes originarios ,le alcanzará con fuerza de cosa juzgada.

Si el tercero demanda, la cuestión común será la discutida entre los litigantes originarios que tendrá también que dilucidarse entre éstos y el tercero pero ya en el ámbito de la acumulación de litis y no en el de la intervención obligada.

\section{Naturaleza de la controversia común}


Pasaremos a analizar la naturaleza jurídica de la controversia común y la de la formación procesal que permitirá llevarla a cabo, tema obviamente distinto del referente a la naturaleza de la denuncia de litis. Diremos entonces que la controversia común referente a la intervención obligada, es el debate sobre la cuestión común que necesita ser resuelta para que lo decidido quede en condiciones de aplicarlo a la solución de una pretensión eventual referente a la misma cuestión. De tal manera y en su sustancia, la controversia común ha de generar una decisión prejudicial ${ }^{\mathbf{3 2 1}}$

Al respecto podemos señalar la existencia de cuestiones prejudiciales establecidas explícitamente por el derecho sustancial (por ejemplo, arts.1101 .1102, 1103, 1104 Cod.Civil; arts 1774 a 1780 CCCN ) y otras por el derecho procesal :por ejemplo, la resolución de la declinatoria y la litispendencia con respecto al resto de las excepciones (art.353 CPCCN);la de las apelaciones diferidas antes de la sentencia definitiva (art.248,última parte CPCCN).O implícita, ejemplo, la derivada del art.92(90) inc. $1^{\circ} \mathrm{y}$ 93(91) primera parte CPCCN: aquello que se resuelva entre el coadyuvado y la contraparte hará cosa juzgada en la controversia futura entre el coadyuvado y el coadyuvante interviniente voluntario (art.96(94) CPCCN). Por último encontramos las que en cada caso se presentan a ser resueltas en la sentencia según el orden jurídico-racional de desarrollo del fallo, de modo de no jugar autónomamente sino en el contexto de la sentencia (por

\footnotetext{
${ }^{321}$ Recordamos por ejemplo al CGP de Uruguay (art.305) que impone a los jueces, de oficio o a pedido de parte, la necesidad de disponer la realización de un proceso previo, sea o no prejudicial, antes de resolver la cuestión para la que fueran requeridos; las disposiciones sobre prejudicialidad penal y civil de la LEC España (arts 40 a 43); la suspensión del proceso del CPC Colombia(art.170,incs.1 y 2), todo sin perjuicio de las disposiciones sobre prejudicialidad del derecho argentino en materia penal y civil
} 
ejemplo, la prueba de la existencia originaria de una obligación,para poder analizar luego si hubo o no, cumplimiento adecuado.

Es claro que la cuestión prejudicial del art.96(94) CPCCN no es una diligencia preliminar (preparatoria o de prueba anticipada) o -con referencia a la conservación de pruebas- una información a perpetua memoria $^{322}$ por más que en ella se hayan reunido elementos de juicio, pues en las figuras mencionadas falta la decisión dirimente que caracteriza a la prejudicialidad. En efecto, para que ésta pueda alcanzarse, será necesario una decisión judicial sobre la cuestión que se necesite tener resuelta y que, como todo decisorio judicial definitivo, otorgará fuerza de cosa juzgada a lo decidido, tanto en los aspectos fácticos como jurídicos.

\footnotetext{
322 "Art.876.CPC Córdoba. Cuando por alguna circunstancia alguna persona se hallare en peligro de perder su derecho, si no se le admite prueba de testigos, podrá producir una información sumaria, con citación de la parte a que haya de perjudicar ,o del asesor letrado en caso de no poder obtenerse lo comparendo de aquélla con la urgencia requerida."
} 


\title{
CAPITULO QUINTO
}

\section{LA DENUNCIA DE LITIS Y EL PROCESO}

\author{
SECCION PRIMERA \\ PROCEDIMIENTO DE DENUNCIA Y CITACION
}

\section{Normativa}

El mecanismo de citación y sus efectos sobre el proceso está tratado en los arts .96(94), 97(95) y 98(96) CPCCN. El art.96(94) CPCCN regula las oportunidades para pedir la citación y la forma de practicarse; por su parte, el art.97(95) determina: "Efecto de la citación. La citación de un tercero suspenderá el procedimiento hasta su comparecencia o hasta el vencimiento del plazo que se hubiere señalado para comparece, ${ }^{, 323}$.

\footnotetext{
${ }^{323} \mathrm{CPCC}$ Buenos Aires, art.95;CPCC Catamarca, art.94;CPCC Chaco, art.94 ; CPCC Chubut, art.96 ;CPCC Corrientes, art.95 ; CPCC Entre Ríos, art 92; CPCC Formosa, art.95 ;CPCC La Pampa, art.85 ;CPCC Misiones, art. 95; CPCC Neuquén, art.94; CPCC Río Negro, art.95 ;CPCC San Juan,art.95 ; CPCC San Luis, art.95 ; CPCC Santa Cruz, art.95; CPCC Santiago del Estero ,art.98 ; CPCC Salta, art.95 ; CPCC Tucumán,art.91. El dispositivo es igual al $95 \mathrm{CPCCN}$ pero en su parte final se agrega "salvo que el juez no lo considere necesario"
}

CPCC Córdoba: “Trámite.Art.434.Con el pedido de intervención voluntaria se ofrecerá la prueba de los hechos en que se funde y se le dará trámite de incidente con intervención de actor y demandado"

"Del pedido de intervención obligada formulada por el demandado se dará traslado al actor. La resolución será apelable.” 
El pedido de citación suspende el procedimiento hasta la comparecencia del citado o hasta el vencimiento del plazo del comparendo."

El tercero, dentro del plazo del emplazamiento o citación, puede impugnarlo y la impugnación se tramitará en la forma establecida para los incidentes."

CPC Mendoza: Ver correspondencia con art.25.II en punto 33.

CPC Santa Fé, art.310.Ver su texto en punto 33; correspondiente a la citación de saneamiento, es aplicable, en general a los casos de intervención de terceros.

Dicho artículo permite la denuncia de litis regresiva por contribución promovida por el acreedor demandante con respecto a los coacreedores ,así como la del deudor con respecto a los coobligados pasivos

CPCC Buenos Aires, art,96 (a) ; CPCC Catamarca, art.96 (a) ; CPCC Chaco, art.96 (a); CPCC Chubut, art.97(a);CPCC Corrientes, art.96(b); CPCC Entre Ríos, art 93(c); CPCC Formosa, art.96(a);CPCC Misiones, art.96(a); CPCC Neuquén, art.96 (a); CPCC Río Negro, art.96(a) ; CPCC San Luis, art.96 (a) ; CPCC Santa Cruz, art.96(a) .CPCC Santiago del Estero ,art.99; CPCC Salta, art 96 (b);CPCC Tucumán, art.92 (b)

(a)Alcance de la sentencia. En todos los supuestos, la sentencia dictada después de la intervención del tercero, o de su citación, en su caso, lo afectará como a los litigantes principales.

Será inapelable la resolución que admita la intervención de terceros. La que la deniegue será apelable en efecto devolutivo".

No contienen el equivalente a la tercera parte del art.98 CPCCN.

(b)La primera parte es equivalente a la segunda parte del art.98 CPCCN; la segunda parte es equivalente a la primera parte del art.98 CPCCN. En ella se utiliza el término "afectará"

No contienen el equivalente a la tercera parte del art.98 CPCCN.

CPCC Córdoba. “Art.435.La sentencia dictada después de la intervención de los terceros, obliga a éstos como a los litigantes principales y será ejecutable en su contra." 
Por su parte, el art. 98(96) CPCCN expresa: "Recursos. Alcance de la sentencia. Será inapelable la resolución que admita la intervención de terceros. La que la deniegue será apelable en efecto devolutivo.

En todos los supuestos, después de la intervención del tercero, o de su citación, en su caso, la sentencia dictada le alcanzará como a los litigantes principales.

CPC La Pampa, “Art.88.Alcance de la sentencia. En todos los supuestos, la sentencia dictada después de la intervención del tercero, o de su citación, en su caso, lo afectará como a los litigantes principales.

Se podrá condenar al tercero si al sustanciarse el pedido de intervención, el actor hubiese adherido y solicitado su condena.

Será inapelable la resolución que admita la intervención de terceros. La que la deniegue será apelable al solo efecto devolutivo."

CPCC San Juan, Art.97. Recursos. Alcance de la sentencia. Será inapelable la resolución que admita la intervención de terceros. La que la deniegue será apelable sin efecto suspensivo.

En todos los supuestos, después de la intervención del tercero, o de su citación, en su caso, la sentencia dictada lo alcanzará como a los litigantes principales

Será ejecutable la resolución contra el tercero si al sustanciarse el pedido de intervención el actor hubiere solicitado su condena, salvo que en oportunidad de formular el pedido de intervención o de contestar la citación, según el caso, se hubiese alegado fundadamente, la existencia de defensas y/o derechos que no pudiesen ser materia de debe y decisión en el juicio"

- CPC Santa Fe, art. 308.Ver texto en punto 33.CPCC Tierra del Fuego, ver art.103 en el punto 34 . 
También será ejecutable la resolución contra el tercero, salvo que en oportunidad de formular el pedido de intervención o de contestar la citación, según el caso, se hubiese alegado fundadamente, la existencia de defensas y/o derechos que no pudiesen ser materia de debate y decisión en el juicio ${ }^{, 324}$.

${ }^{324}$ CPCC Buenos Aires, art.95;CPCC Catamarca, art.94;CPCC Chaco, art.94 ; CPCC Chubut, art.96 ;CPCC Corrientes, art.95 ; CPCC Entre Ríos, art 92; CPCC Formosa, art.95 ;CPCC La Pampa, art.85 ;CPCC Misiones, art. 95; CPCC Neuquén, art.94; CPCC Río Negro, art.95 ;CPCC San Juan,art.95 ; CPCC San Luis, art.95 ; CPCC Santa Cruz, art.95; CPCC Santiago del Estero ,art.98 ; CPCC Salta, art.95 ; CPCC Tucumán,art.91. El dispositivo es igual al $95 \mathrm{CPCCN}$ pero en su parte final se agrega "salvo que el juez no lo considere necesario"

CPCC Córdoba:Trámite.Art.434.Con el pedido de intervención voluntaria se ofrecerá la prueba de los hechos en que se funde y se le dará trámite de incidente con intervención de actor y demandado

Del pedido de intervención obligada formulada por el demandado se dará traslado al actor. La resolución será apelable

El pedido de citación suspende el procedimiento hasta la comparecencia del citado o hasta el vencimiento del plazo del comparendo

El tercero, dentro del plazo del emplazamiento o citación, puede impugnarlo y la impugnación se tramitará en la forma establecida para los incidentes

CPC Mendoza: Ver correspondencia con art.25.II en punto 33

CPC Santa Fé, art.310. Ver su texto en punto 33 ; correspondiente a la citación de saneamiento, es aplicable, en general a los casos de intervención de terceros.

Dicho artículo permite la denuncia de litis regresiva por contribución promovida por el acreedor demandante con respecto a los coacreedores, así como la del deudor con respecto a los coobligados pasivos 
El art.96(94) CPCCN fija las oportunidades establecidas para solicitar la citación También determina la manera de practicarla; el art.97(95) impone la suspensión el procedimiento. Por su lado el art.98(96) en su primera parte determina la recurribilidad de la decisión denegatoria de la citación. Se trata de reglas aplicables, en principio, a toda denuncia de litis.

\section{Oportunidad de denunciar}

a) El CPCCN. El art.96(94) CPCCN determina momentos y tiempos para formular la denuncia de litis y en consecuencia, para requerir la citación de terceros: el actor debe hacerlo al demandar en tanto el demandado ha de formalizarlo dentro de los plazos establecidos para oponer excepciones previas -sería aplicable a los procesos ordinarios- o para contestar la demanda en otro tipo de procesos. La ley 25.488 cambió el sistema originario y no solo eliminó los procesos sumarios sino también el plazo específico de oposición de excepciones, las que deberán ser deducidas junto con la contestación de la demanda (art.346 CPCCN). Pese a que se mantiene la redacción originaria del art.96(94) $\mathrm{CPCCN}$, debe entenderse que para el accionado, solo queda vigente el plazo para el responde, solución aplicable a todo tipo de procesos en los que sea posible la litisdenuncia. La letra legal no impide que el demandado conteste y al mismo tiempo pida se practique la litisdenuncia, pero también posibilita que solamente se formule tal solicitud sin contestar la demanda. En efecto, si bien se elimina el plazo propio para excepcionar y se impone hacerlo junto con la contestación de la demanda, el art.96(94) CPCCN no obliga a que el pedido de citación y el responde y excepcionamiento se hagan en un mismo acto. Sin embargo y por encima de la letra normativa, acerca del 
sentido real de tal sistema, la contestación de demanda y la paralización del proceso, nos remitimos a lo expuesto en el punto 77 .

Con respecto a la denuncia de litis promovida por el actor, creemos que no existe inconveniente en que lo haga a posteriori, pero antes de correr el traslado de la presentación inicial (arg. art.331 CPCCN).

b) Códigos no modificados. El tema nos lleva a considerar la situación de los códigos que mantienen la separación entre las oportunidades de excepcionar y las de contestar la demanda. En aquéllos, la denuncia de litis puede pedirse antes de vencer el tiempo previsto para oponer excepciones o a ese momento pero no más allá, pero de todos modos, podrá hacerse antes de la contestación de la demanda ${ }^{325}$.De tal manera si la citación se pide antes de excepcionar o al tiempo de hacerlo, se suspende el procedimiento. Ver sin embargo, lo expuesto en el punto 77 acerca del tema.

c) Situaciones especiales. De todos modos, entendemos que el descripto constituye el esquema básico ya que ha de ser adecuado a las circunstancias de la causa. Frente a ellas, se ha resuelto que procede la citación propiciada por el actor después de producida la contestación de la demanda y a raíz de los hechos puestos de manifiesto por el responde, a los que se catalogaron como hechos nuevos ${ }^{326}$. El fallo mereció la crítica de

\footnotetext{
${ }^{325}$ En los procesos ordinarios antes de la reforma introducida en el CPCCN por la ley 25.488, no era posible dejar pasar el momento de excepcionar-así no se las opusieranpara hacerlo recién con el responde, sino que se debía hacerse necesariamente en esa primera oportunidad o se perdía el derecho de litisdenunciar.( CN Com.Sala A,7/7/95 Siemens S.A. c/Guiliani y Asociados F.U.S.A.L.L.1996-A-349)

326"'Si bien es cierto que el art.94 del cód. procesal establece que el actor podrá pedir la citación en la demanda, no lo es menos que cuando los hechos que motivaron la citación llegan a su conocimiento con el escrito de responde, su posterior solicitud debe
} 
Kenny que sostuvo la imposibilidad de citar ya que frente a los hechos nuevos del responde, la ley solo autoriza al actor a presentar documentos a ellos referidos ${ }^{327}$. Observamos sin embargo que no se trató de un tema de aplicación del art.96(94) CPCCN -no obstante de la errónea mención en el fallo del término "citación"- sino de una ampliación subjetiva de demanda 328. La utilización del concepto de "hechos nuevos" por el fallo y el comentario al que se refiere la nota 328 nos obliga a detenernos en el tema: el hecho nuevo no es el conocido por el aportante pero incorporado por primera vez en la contestación (art.334 CPCCN), sino el inexistente o desconocido al tiempo de demandar o de responder, alegable hasta cinco días posteriores a la notificación de la audiencia de prueba (art.368(365)) CPCCN) o en segunda instancia en oportunidad del art.262(260) inc.5 a) de dicho código. Pensamos que si la citación se pretende en la oportunidad del art.368(365), resulta posible admitirla -reunidos los presupuestos adecuados- ya que si bien ya está ordenada y notificada la apertura a prueba, no se produce mayor alteración en la marcha del proceso; distinto es el caso de una citación en la segunda instancia, ya que ocasionaría una verdadera desarticulación del juicio. Las que luego se intenten bajo la denominación de citaciones, solamente serán procedentes si configuran una pretensión dirigida contra el tercero; por ejemplo, en el caso del

considerarse una ampliación de la demanda fundada en un hecho nuevo y como tal, enteramente procedente. No se trata de la inserción de una nueva pretensión ni de la alteración objetiva de la ya interpuesta, lo cual obstaculizaría su admisibilidad sino de la integración de ésta"(CN CIV.Sala D,21/21/96.Lafroc Rubén A.c/Conte de Sealisa Leonor y otra ED 75-242)

${ }^{327}$ Kenny Héctor Eduardo. Obra citada, pgs 92 y 93)

${ }^{328}$ Con igual sentido el fallo considerado por Kenny, Sala F 16/8/78 Migdal Abraham c/Piagio Mercedes y otra.ED 121-343,nº110 );CN Com.Sala D,25/10/95 Rodríguez Calles Rodolfo c/Cornes Guillermo L.L.1996-B-709- 38.470 S-) 
colegitimado citado por el demandado en un cuasi delito, empalmándolo, como es de práctica, con la previa reserva de ampliar la demanda hacia un demandado genérico-o aun sin ella- y formulándolo antes de abrirse la causa a prueba ${ }^{329}$.

En esa línea interpretativa, ha sido admitida la citación como terceros de los originariamente codemandados si se produjo -si bien en el período probatorio- inmediatamente después de que el actor desistiera de su demanda contra los mismos, colocándolos desde entonces en una nueva calidad $^{330}$.

\section{Solicitud y fundamentos}

Es una obviedad decir que la denuncia de litis y el consiguiente pedido de citación ha de formularse por escrito; desde el punto de vista formal, corresponde asimilarlo a la pieza de formación de un incidente por lo que serán aplicables las exigencias de sustentación y aporte probatorio que impone el art.176(175) CPCCN. Tales extremos hacen a una carga destinada a permitir que el juez pueda resolver adecuadamente, de modo que al criterio expuesto no ha de oponerse la letra normativa que parece

${ }^{329}$ CNCiv. Sala A,3/11/ Viñas Alfredo c/Santamaria de Caffaro LL 107-1979. Observamos que el art.25 I. CPC Mendoza permite al actor citar hasta diez días después de la contestación de la demanda si de esa pieza surgiera la necesidad de hacerlo. Interpretamos esa norma como referida exclusivamente a los casos en los que el demandante pueda pedir la asunción de defensa por parte de un tercero (evicción o aseguramiento) pues no vemos que el actor pueda citar como terceros y no demandarlos, a quienes la contestación de demanda mencione como responsables

${ }^{330}$ CN Com.Sala A, 22/5/91 Ankober S.A. c/Coll Jaime B.y otro L.L.1992-D,256.) 
remitirse a la sola invocación de existencia de controversia común ${ }^{331}$. Pensamos en cambio, que la viabilidad de la solicitud depende no solamente de la fundada invocación de ese presupuesto sino de todos los que consideramos deben darse en la materia.

\section{Inadmisibilidad y sustanciación}

Cualquiera sea la parte que haya formulado el requerimiento y con más razón si proviniere del demandado, el juez puede inadmitirlo liminarmente por extemporáneo o por visible falta de fundamentos ${ }^{332}$.

A diferencia del caso de intervención voluntaria, la ley nada dice acerca del procedimiento a seguir una vez planteada la denuncia de litis; por comparación con el art.92(90) CPCCN y argumento a contrario, parecería que el silencio normativo descarta la sustanciación e impone directamente una resolución del juez. Según Palacio, la citación requerida por la parte demandada, a diferencia del pedido formulado por el actor, debe sustanciarse, aplicándose al efecto el sistema del art.94(92) $\mathrm{CPCCN}^{333}$. Kenny manifiesta que la sustanciación debe darse siempre

\footnotetext{
${ }^{331}$ Igual modalidad expresan los demás códigos argentinos salvo el CPCC La Rioja en su art.145 que impone a la parte que pide la citación, indicar los motivos por los cuales considera que la controversia es común

${ }^{332}$ Por ausencia de fundamentos, no procede la citación si el peticionante se limitó a transcribir sumarios jurisprudenciales sin relacionar la doctrina de los mismos con lo debatido en la causa (CN.Trabajo Sala IV,30/6/2010 Moradro Lina c/Televisión Federal,D.J.9/12/2010 p.80.)

${ }^{333}$ Palacio Lino E.Derecho Procesal.. citado, T.III, pg.217
} 
mediante el trámite de los incidentes ${ }^{334}$; por el contrario, Martínez piensa que el juez debe resolver sin escuchar a la contraria sea quien sea quien pida la convocatoria; afirma que el derecho de defensa quedaría asegurado por la posibilidad de plantear reposición ${ }^{335}$. Por su parte, Falcón entiende que no corresponde correr traslado como lo propicia Palacio, sino notificar por nota al actor posibilitándole que manifieste su oposición ${ }^{336}$. A favor de la improcedencia de la sustanciación, la solución dada por el art.105 CPCCN en materia de evicción ${ }^{337}$ pero entendemos que no es aplicable a la intervención genérica pues en la garantía formal juega una exigencia relativa al grado de convicción (art.107(105) segunda parte $\mathrm{CPCCN}$ ) que no figura ni parece aplicable a los casos de garantía simple (ver al respecto el punto siguiente)

La sustanciación está establecida expresamente en muchas legislaciones $^{338}$

En las denuncias de litis planteadas por el actor, es difícil encontrar un justificativo para sustentar la necesidad de oír al demandado : en nada se

\footnotetext{
${ }^{334}$ Kenny Héctor Eduardo. Obra citada, pgs 87 y 88 )

${ }^{335}$ Martínez ,Hernán J.Obra citadaT.I,pg.344

${ }^{336}$ Falcón Enrique ,Código.. citado,T.I,pg.524

${ }^{337}$ Igualmente art.91 CPC Jujuy, art.305 CPC Santa Fe, Proyecto Reimundin-art.76-.

${ }^{338}$ Así, art.94 segunda parte CPCC San Juan; arts 88, segunda parte y 127 inc.8 CPCC La Pampa; art.104 CPCC Tierra del Fuego; el art.434 segunda parte CCPCC Córdoba, si lo pide el actor. En la tercera parte del 145 CPCC La Rioja se determina que en el trámite de las tercerías se aplicará en lo pertinente el de los incidentes; para éstos (arts 136 a 141) se establece la necesidad de sustanciación, con ofrecimiento de pruebas en los escritos constitutivos y posibilidad de rechazo oficioso in límine; pero, como la demanda incidental requiere de la existencia previa de una contraparte del principal, pensamos que en la materia que nos ocupa, solamente habrá de sustanciarse la que se pidiera por el demandado.
} 
vería perjudicado con la presencia del tercero . Si lo propicia el demandado parece necesario oír al actor para evitar que se trate de un mero intento dilatorio o de que existan otras causas de improcedencia, además que, de todos modos, la presencia de un tercero aunque no produzca un gravamen irreparable, siempre significará una mayor complejidad procesal. Por ende consideramos que el pedido deberá sustanciarse. En ese caso, puede utilizarse la notificación por cédula por tratarse de un incidente (art.181(180) segunda parte CPCCN) pero no es descartable hacerlo por nota para brindar oportunidad para que el actor consienta o cuestione el pedido de convocatoria, con lo que se cubre igualmente su derecho de defensa. Como todo traslado se dicta en calidad de autos (art.150(151) $\mathrm{CPCCN}$ ) no hay razón para designar audiencia y aplicar el procedimiento previsto para el ingreso voluntario, es decir para caso distinto.

Pensamos que si la denuncia es formulada por un litisconsorte por motivos extensibles a los demás, corresponderá darles participación antes de resolver el pedido de modo que lo que se decida tenga valor común.

\section{Criterio de otorgamiento}

La ley procesal establece en materia de evicción el grado de convicción judicial que ha de darse para hacer lugar al pedido de citación del garante. Así, el art.107(105) CPCCN autoriza a hacer lugar si fuera manifiestamente procedente. En cambio, nada dice la ley en los dispositivos que consideramos aplicables a la intervención obligada genérica. En general se considera que tal como corresponde a toda participación de ajenos al esquema subjetivo inicial, el llamamiento del art.96(94) CPCCN debe ser 
admitido con criterio restrictivo en especial si lo requiere la parte demandada ${ }^{339}$.

Con acierto, Alvarado Velloso dice que es errónea la afirmación según la cual la citación requerida por el demandado debe ser concedida con extremo rigor dado que el actor no puede ser forzado a litigar con quien no quiere, pues lo importante es salvaguardar el principio de seguridad jurídica mediante la unidad de juzgamiento ${ }^{340} \mathrm{y}$ también la jurisprudencia se ha expedido en ese sentido ${ }^{341}$. Por su parte Morello propicia apartarse de los

339 " $L a$ intervención de un tercero es una medida excepcional que debe ser interpretada con criterio restrictivo, en especial si es pedida por el demandado, pues obliga al actor a litigar contra quien no ha elegido como contrario. Por tanto, no basta la mera solicitud del citante, sino que sólo debe admitírsela si se cumple con los requisitos establecidos en el capítulo VIII del título II del Cód. Procesal y frente a circunstancias especiales en las que exista un interés jurídico que corresponda proteger" (CN Civ. Sala E,20/8/96, Gallego Beatriz y otros c/ Evina S.A. y otro. L.L.1996-E-665.). Con sentido similar CSJN 14/5/87, Fernández Propato Enrique c/ La Fraternidad. LL 1987-D,494 ;CON Fed.Contenciosoadm.Sala III, 22/3/88, Domínguez Pedro c/Gobierno Nacional, Georgias del Sur S.A. y Estado del Reino Unido de Gran Bretaña, L.L. 1988-E,327; CN Civ.Sala D 7/8/78. Santarelli Osvaldo c/Fesler Oscar L.L.1978-B-370. CN Trab Sala VIII 31/8/94 Vallejos Ricardo J. c/ENTEL y otro.D.T.1995-A-673. CN Especial Civil y Com. Sala A ,21/9/82 E.D.100-319. CN Federal Civil y Comercial, Sala III,18/2/2005 Ramirez Isabel y otros c/Sanatorio San José y otros LL 2005-D-727.A ello agregamos la constante jurisprudencia de la Corte Suprema

${ }^{340}$ Alvarado Velloso Adolfo. Obra citada, pg. 166.

${ }^{341}$ "La intervención de terceros, si bien es de carácter restrictivo, debe ser admitida cuando las circunstancias demuestren que así lo exige la protección de un interés jurídico vinculado con el objeto de la pretensión o indican la existencia de una comunidad de controversia que llegue a afectar al tercero patentizando funcional la citación" (CN Trab.Sala VII 12/8/96 Brykman de Bauni Malka R.c/Ceprimed S.A. D.T.1996-B-2772). "No existe impedimento alguno para que a pedido del demandado se dé intervención a un tercero en el juicio, cuando entre las partes y éstos, pueden existir relaciones jurídicas comunes y conexas que conviene resolver en el mismo proceso, no sólo por economía procesal, sino también para evitar la posibilidad de evitar fallos contradictorios". En el caso, se trataba de la citación, pedida por el demandado, ( por una eventual acción de regreso) con respecto al escribano por incumplimiento de 
criterios clásicos para, en cambio, tener en cuenta el objetivo de una justicia eficiente ${ }^{342}$.

Pensamos que la solución del art.107(105) CPCCN no es utilizable en el instituto que estudiamos ya que en la evicción será fácil, sobre todo si el juicio versa sobre bienes registrables, percibir la condición de transmitente o enajenante del citado,en tanto es más difícil de percibir la eventual responsabilidad del tercero en la garantía genérica. Frente al requerimiento del actor, corresponde aplicar un criterio de ponderada amplitud. Ello no significa que el juez deba aceptar el pedido de dicha parte sin un análisis acerca de su razonabilidad, pues en todo caso debe preservar el orden del proceso y evitar el desgaste jurisdiccional. En cuanto al requerimiento del demandado, es claro que nunca puede apuntar a forzar al actor a litigar contra quien no quiere; así, si se trata de litisdenuncias excluyentes, será el tercero el que demande contra aquél, cosa que nadie puede impedirle ,y si fuera una regresiva u otras extensiva, el actor no tendrá el deber de tener al citado como demandado, salvo que así lo desee. Las molestias que puede ocasionarle la presencia de un tercero no pueden ser opuestas válidamente al derecho del convocante destinado a involucrar al llamado en el conflicto del que se trate. No debe haber entonces criterios amplios o restrictivos, sino de justa apreciación de existencia de los presupuestos necesarios para dar viabilidad a la citación y del interés de la parte en hacerlo. Precisamente ese interés ha de moverle a demostrar aquellos extremos. Si se generaren dudas al respecto, ha de tenerse en

deberes profesionales (Cam. Civ y Com.Lomas de Zamora, Sala II, 29/7/93 Valfos S.A. c/ Berdndt.L.L.Buenos Aires.1994-200)

${ }^{342}$ Morello Augusto M.El tercero en el proceso ¿Un supuesto excepcional y de interpretación estricta? LL 2005-D-728.) 
cuenta que el ingreso del tercero no causa gravamen irreparable al actor y que, por el contrario, una negativa puede generarlo en el demandado ${ }^{343}$. La conducta del actor ante un requerimiento formulado por el contrario puede ser pauta a tomar en cuenta ${ }^{344}$. Es oportuno recordar que el Proyecto Fernández permitía al juez, de no advertir prima facie la procedencia de la citación, disponerla pero sin suspender el curso del juicio (art.81)

\section{Resolución}

Si el pedido de citación fue sustanciado, corresponderá resolver con la consiguiente interlocutoria (art.162(161) CPCCN) y tratándose de una forma incidental, con la condena en costas consiguiente. De no haberse sustanciado, no obstante, nos parece que la convocatoria no es un acto que tienda al desarrollo normal del proceso u ordene actos de ejecución y que pueda decretarse sin otro fundamento que la expresión de voluntad del juez .Aun tratándose de un pedido del actor, su procedencia no es automática por la complejidad procesal que acarrea; así, la resolución siempre tendrá que tener un fundamento que indique -con mayor o menor detenimiento- que es aceptable la postulación del peticionante por están

\footnotetext{
${ }^{343}$ Adviértase el principio de inapelabilidad de la resolución que admite la intervención de un tercero (art.96(94) CPCC).

${ }^{344}$ Corresponde acoger en forma favorable la citación del tercero peticionada por la demandada, teniéndose en cuenta la falta de oposición de la actora al respecto y el hecho de que no es posible aseverar con certeza la inexistencia de una comunidad de controversia ni eventuales acciones regresivas, sin que ello implique adelantar opinión alguna sobre el fondo el litigio" (CN Trabajo, Sala IX, 31/3/2011 Ramos María Rosa c/Asociación Francesa Filantrópica y de Beneficencia del Hospital Francés. LL Rep.LXXI,pg.1395, nº)
} 
dados -prima facie- los presupuestos necesarios para ordenar el llamamiento; es claro que para entonces, el juez no puede prejuzgar acerca de la responsabilidad del citado frente al citante o del derecho del citante sobre el derecho discutido. De la ley procesal no resulta la necesidad de que la citación contenga algún apercibimiento destinado a alertar al citado de las consecuencias de la notificación. Por el contrario, los efectos no aparecen condicionados a otra actividad (arts 97(95) y 98(96) segunda parte CPCCN) y por tanto han de producirse ipso iure. La fundamentación se impone con mayor razón si se deniega el pedido, inclusive por la apelabilidad de lo resuelto.

\section{Recurribilidad}

La decisión del juez es inapelable si admite la intervención y apelable con efecto devolutivo si la deniega (art.98(96) primera parte $\mathrm{CPCCN}^{345}$. Las soluciones referidas son aplicables a todo tipo de denuncia de litis. Se ha sostenido que la inapelabilidad alcanza tanto a lo principal como a las costas que pudieron resultar de la oposición ${ }^{346}$. La posibilidad de recurrir incumbe, no al tercero cuya citación se deniega, y que, obviamente, no

\footnotetext{
${ }^{345} \mathrm{El}$ proyecto Reimundin establece la apelación en relación para todos los casos

${ }^{346} \mathrm{CN}$ Civ.Sala E, 27/5/82, Lovito José M.c/Municipalidad de la Ciudad de Buenos Aires. ED 121-351, n ${ }^{\circ} 210$. No estamos de acuerdo con lo decidido pues la incorporación del tercero no causa gravamen irreparable, pero sí lo provoca la imposición de costas pues la inapelabilidad las deja firmes; no encontramos razón que justifique que si son generadas en cualquier incidente se las podrá apelar en diferido, pero no así en el que provoca el pedido de citación.
} 
tiene para entonces participación en el juicio, sino a la parte originaria que ve descartado su pedido ${ }^{347}$.

Como la sustanciación previa deviene en interlocutoria, para resolver la cuestión no resulta posible deducir reposición tanto cuando se admita como cuando se rechace el pedido de intervención.Si se admitió,no obstante decretarse el llamamiento por una interlocutoria, debe prevalecer por ser lo específico y no darse gravamen irreparable, la inapelabilidad prevista en el art.98(96) según se expresa más arriba.Ante la denegatoria,dado el efecto devolutivo de la apelación, la causa seguirá su curso hasta que se decida por la alzada. Si ésta revoca, habrá que anular lo actuado en cuanto afectara el derecho de defensa del tercero, ya que de lo contrario se obligaría al citado a tomarla in statu et terminis ${ }^{348}$. De no haberse sustanciado el pedido de citación,actor o el demandado, al ver denegado sus pedidos podrán pedir reposición con apelación subsidiaria; si la postulación fuese acogida, podrán plantear reposición la que se sustanciará sin que quepa apelación.

En el proceso laboral nacional, en el que, como regla general, las apelaciones anteriores a la sentencia se tienen presente con efecto diferido (art.110, ley 18.345), debe tratarse de inmediato la denegatoria al pedido de

\footnotetext{
${ }^{347}$ CN Civ. Sala F ,15/10/80. Rega Molina Mariana c/López de Crocco Irene. LL 1981A-318

${ }^{348}$ Leguisamón entiende que para que el tercero no tenga que tomar el juicio in statu et terminis sería menester que la apelación se concediera en ambos efectos y recuerda que esa es la solución adoptada por los proyectos de códigos civil y comercial elaborados por los Dres Morello, Esiner,Arazi y Kaminker.(Leguisamón Héctor Eduardo.La intervención...citado, pg.207).
} 
citación de tercero pues tal postergación a momento posterior al fallo sería de una esterilidad total y generaría un dispendio judicial innecesario ${ }^{349}$

\author{
SECCION SEGUNDA
}

EFECTOS SOBRE EL PROCESO

\title{
77. Efecto de paralización del proceso
}

El art.97(95) dispone que "la citación de un tercero suspenderá el procedimiento hasta su comparecencia..."etc. La norma resulta aplicable a toda clase de denuncia de litis.

Pareciera que el efecto de paralización lo produce la notificación al tercero, solución que no es razonable pues éste debe tomar el proceso en su etapa constitutiva y el juicio pudo, entre tanto, seguir adelante cuando en todo caso debe asegurarse el derecho del citado a ingresar en aquel momento y no llevar a tomarlo in statu et terminis; entonces, tendrá que considerarse el efecto ex nunc de toda resolución judicial de modo que la sola petición producirá como principio y consecuencia, el congelamiento de la tramitación del juicio en el estado necesario para concretar la retroactividad(ex tunc) de lo que se resuelva; así y si la denuncia parte del actor, se suspenderá el proceso hasta la decisión que recaiga al respecto; si la misma admite la citación, se extenderá la paralización hasta la comparecencia del tercero o el transcurso del plazo otorgado para su

\footnotetext{
${ }^{349}$ Cám.Nac.Trab.Sala IX,16/11/2006 Barrionuevo Hinojosa c/Alegre Pavimentos LL Repertorio 2007,pg.746, ${ }^{\circ} 3$.
} 
concurrencia. Igual solución se aplicará ante la denuncia del demandado, pero en este caso podrá esperarse a que se resuelva favorablemente si el magistrado advirtiera el escaso fundamento de la petición (Proyecto Fernández, art.81 in fine).

La letra de los arts.96(94) y 97(95) CPCCN lleva a afirmar que en la suspensión del proceso derivada del pedido de citación formulado por el demandado, queda comprendida la contestación de la demanda ya que dicha parte puede formularlo en el tiempo fijado para hacerlo sin que se imponga que, previamente, se produzca el responde. De tal manera y salvo que conteste y al mismo tiempo solicite la notificación, podría conseguir en los hechos un alongamiento del tiempo para el responde sin que se pueda advertir qué necesidad insoslayable puede justificar la presencia del tercero antes de que fije su postura ante el adversario, máxime cuando puede ocurrir que aquél se abstenga de concurrir al pleito. La convocatoria sin responde podría caber en las litisdenuncias excluyentes pues al actor le sería suficiente con conocer los fundamentos del pedido de su contrario y al tercero le basta saber de la demanda para advertir si versa sobre un derecho propio. Lo mismo ocurren en las denuncias regresivas de responsabilidad por garantía (aseguramiento y evicción) ${ }^{\mathbf{3 5 0}}$, pero en el resto de las denuncias regresivas se colocaría al tercero en una situación de indefensión pues si bien el fundamento de la petición de convocatoria puede darle alguna pauta, se le estará llamando sin saberse en definitiva cuál es la posición que asumirá ante el actor y por ende sin que pueda tener en claro el

${ }^{350}$ En efecto, en los supuestos mencionados encontramos un régimen especial resultante de la ley 17.418 (art.115) que permite al asegurador propio saber a qué atenerse frente a la demanda contra su asegurado. En la evicción, en tanto el vicio atribuido en la demanda hace al tiempo en que el derecho pertenecía al citado, éste puede manejarse con el solo escrito inicial. 
temperamento a seguir. Pensamos que el tercero citado en esas condiciones podría pedir fundadamente que se le practique nueva citación luego de producirse la contestación faltante.

Debe tenerse en cuenta que en la intervención genérica la presencia del tercero no libera al demandado de su carga fundamental como lo es la contestación en tiempo y forma, salvo que,en esas condiciones, expresamente manifieste que tiene por suya la presentada por su coadyuvante. No debe perderse de vista que si bien los tiempos para concretarla son los que figuran en los códigos fuentes del CPCCN entre ellos el de Jujuy, éste, (art.79) al igual que el proyecto Reimundin (art.65) determinan que "El tercero interviniente será oído después de la contestación del demandado"351. En definitiva sostenemos que si bien la parálisis procesal comienza al pedirse la citación, ello opera sobre toda actividad salvo la de contestar la demanda ${ }^{352}$.

En todos los casos, si el pedido de citación no fuese admitido, con la resolución cesa el efecto de suspensión del procedimiento sin perjuicio de los recursos en devolutivo que pudiera presentarse que, dada esa modalidad

\footnotetext{
${ }^{351}$ La ley de enjuiciamiento civil de España,art.14.2 considera que la convocatoria suspende el plazo de contestación de demanda; el art.382 C.Pr.Venezuela, por el contrario impone que el demandado pida la citación con la contestación de la demanda

${ }^{352}$ La solución sustentada en el texto, es acorde con la propósito general del CPCCN de no permitir dilaciones innecesarias para contestar la demanda. Al respecto puede recordarse la parte final del art.346 CPCCN. Este mismo dispositivo establece que aquél acto se suspende si se hubieran opuesto las excepciones de arraigo, falta de personería o defecto legal. En tal caso pensamos que tales excepciones se sustanciarán y resolverán, completándose o comenzado (arts.354,355( 354 bis CPCCN) luego el plazo para el responde para que una vez producido se paralice el proceso a la espera del tercero.
} 
impugnativa, no impedirán el reinicio del juicio con sujeción a la decisión de alzada.

\section{Plazos de paralización}

Ante el pedido de citación y luego con su resolución favorable, el juez debe fijar el plazo para la comparecencia, lapso que coincidirá con la paralización del proceso. En tal tiempo, el peticionante deberá asumir la tarea de concretar la litisdenuncia, cuya notificación al tercero fijará el punto de partida para medir el tiempo que se le otorga para deducir o no un incidente de exclusión o para concurrir o no al proceso si se tratare de una citación regresiva. De tal manera, la paralización del juicio comprenderá el tiempo que puede llevar formalizar la convocatoria con más el que se otorgue al tercero a los fines descriptos; ello muestra la existencia de dos momentos sucesivos y de la necesidad de considerar y establecer dos plazos: el de convocatoria y el de concurrencia.

a) Plazos de la convocatoria. Así como la ley remite al criterio judicial la fijación del plazo de comparecencia del citado, omite referirse a la concreción del llamamiento a que ello puede tener incidencia negativa en el proceso y provocar, fundamentalmente cuando lo propicia la parte demandada, un estiramiento de la detención no querido por la norma.

b) Plazo de comparecencia. Al estar paralizado el proceso, o al paralizarse al admitirse la citación, el tribunal deberá fijar un plazo para la comparecencia del citado o la iniciación del incidente respectivo si se tratare de denuncia de litis excluyente. El comienzo de dicho lapso estará dado por la notificación del llamamiento al tercero. La ley no lo 
predetermina de modo que será uno de carácter judicial y por ende perentorio que quedará librado al prudente criterio del juez. Si la litisdenuncia es excluyente no tiene porqué ser el de una contestación de demanda. Si lo es regresiva, el de tal contestación parece prudente si se piensa en la posibilidad de que el tercero concurra y pase a enfrentar al actor. Varios códigos establecen los plazos haciéndolo coincidir con el fijado para contestar la demanda. ${ }^{353}$. El citado goza, de todos modos, del plazo de gracia del art.126(124) $\mathrm{CPCCN}^{354}$.

\section{Carga de materializar la citación}

Si bien la norma no especifíca en cabeza de quien pesa tal tarea, es obvio que deba ser en la del interesado en la concurrencia del tercero; por ende, es carga del litisdenunciante llevar adelante lo necesario para concretar la denuncia de litis. Ello hace al buen orden del proceso y es exigible a tal sujeto como manera de evitar la prolongación innecesaria de la paralización del juicio ${ }^{355}$.

\footnotetext{
${ }^{353}$ CPCC San Juan, art.94; CPCC La Pampa, art.86;PC La Rioja,art.147; CPC Mendoza, art.26.

${ }^{354}$ Feijo Claudio Ramón.”Oportunidad para el demandado de citar a un tercero en el proceso ordinario" y jurisprudencia que cita.L.L.7/2/96;CN Civ.Sala C,30 /3/84 Ineze Kielche Maria c/Kielche Francisco LL Repertorio XLIV 1984 pgs 1203 nº 11 y 12

355 .CN Civ.y Com.Fed,Sala I,17/4/79 Williams Marítima y Com. S.A. y J.R. LL 1979C,87; CN Civ, SalaB 17/2/76 La Franco Argentina Cía de Seguros c/García Manuel ED 121-343,nº18; CN Com.Sala B,21/3/75 Sardoñons Ricardo c/Merlocar S.A. ED 61-607. Así lo dispone expresamente el art.82.II del Proyecto Fernández y lo establece el art.94, tercer parte in fine CPCC San Juan, salvo que el contrario la asuma voluntariamente.
} 
Ocurre sin embargo que si se fija solamente un lapso para la concurrencia del tercero, la carga de citarlo no queda sujeta a plazo perentorio y la actividad del interesado en la convocatoria, dependerá de una intimación promovida por la contraparte ${ }^{\mathbf{3 5 6}}$. En esa misma línea vemos que según el art.80 CPC Jujuy, el reinicio no se produce con la finalización del plazo de comparecencia sino con la providencia que da por decaído el derecho de intervenir en el juicio ${ }^{357}$. En el punto anterior propiciamos la fijación de un plazo específico que al ser judicial, conlleve la perentoriedad que torne innecesaria cualquier intimación y provoque el automático decaimiento de la posibilidad de atraer al tercero. Es por eso que pensamos en la necesidad de que se fije un tiempo preciso para que se cumpla con la citación ordenada ${ }^{358}$.

Igualmente, C.1 ${ }^{\text {a }}$ CC Bahía Blanca, Sala I,12/8/80, Muiños Manuel y otros c/ Perez Norberto y otro. ED 121-343 nº119.

356 "Si la citación de terceros fue dispuesta en exclusivo beneficio del demandado, y era a él a quien correspondía activar su comparecencia, la actuación cumplida (denuncia de nuevos domicilios) no acompañada del oportuno libramiento de cédulas, no puede tener por cumplimentada la intimación a activar la citación de los terceros, siendo por tanto correcta la decisión que hizo efectivo el apercibimiento dispuesto en cuanto tuvo a aquél por desistido de tal citación" (CN Fed. Contencioso administrativo Sala I. Estado Nacional-Ministerio de Salud y Acción Social-c/Pereyra S.R.L.L.L.1992-B425). También será posible que para sacar la causa de su paralisis,el actor asuma la tarea que debió cumplir su contrario(Martínez Hernán J.Obra citada, pg.291).

\footnotetext{
${ }^{357}$ Se trata de una excepción-autorizada por la propia ley-al principio de perentoriedad de plazos establecido por el art.187 del CPC de la Provincia de Jujuy. El Proyecto Reimundin preveía un auto de decaimiento y su notificación (art.63)

${ }^{358}$ CN Com.Sala D 19/6/74. Líneas Aéreas Patagonia Argentina c/La Universal Cía Argentina de Seguros ED 58-271.El Proyecto Fernández, establece que el tribunal al disponer la citación, fijará un plazo para que la misma se efectúe ;no cumpliéndose se produce el decaimiento automático del derecho a citar (art.82.I y II). El art.94 del CPCC San Juan establece que ordenada la citación quien la hubiese promovido tiene cinco días
} 


\section{Forma de citación}

$\mathrm{El}$ art.96(94) CPCCN se remite a los arts. 339 y siguientes en cuanto a la forma de practicarse el acto de notificación y además prevé los medios utilizables para el caso de conocerse dicho lugar; además, según lo dispone el art. 137(136) segunda parte CPCCN, para la de citación de personas extrañas al juicio se utilizará la cédula o el acta notarial. Agregaremos el oficio si se llamara a los estados, nacional o locales. Con la notificación será necesario brindar al tercero el mayor panorama posible de la cuestión para la que se lo llama, a fin de que pueda tomar la decisión adecuada acerca de su abstención o concurrencia y sustentación de su presencia en el juicio; de tal manera con la cédula o la notificación notarial se acompañarán las copias de la petición de convocatoria y sus fundamentos, de la resolución judicial y de las piezas constitutivas generadas hasta el momento ${ }^{359}$. Entendemos que se impone que se deje el aviso previsto en el art.339 segunda parte CPCCN.

Se ha discutido si ante el desconocimiento del domicilio del convocado puede llamarse por medio de edictos. Palacio sostiene que en materia de citación al tercero pretendiente, no procede utilizarlos dada la índole de tal intervención ${ }^{360}$ y Kenny lo critica por considerar que el art.343 CPCCN que implementa la notificación edictual, está comprendido en la remisión que

para notificar al tercero, bajo apercibimiento legal de tenerlo por desistido. En el CPC Jujuy, si bien en materia de evicción, el art.91 establece un plazo de veinte días para que el citante haga practicar las diligencias necesarias para dar conocimiento al citado.

${ }^{359}$ Conf.Kenny Héctor Eduardo.-Obra citada,pg.96

${ }^{360}$ Palacio Lino Enrique. Obra citada, t.III ,pg.228) 
formula el art.96(94) $\mathrm{CPCCN}^{361}$. Nos parece que no hay razón que impida utilizar edictos ya que es el que corresponde a los casos de imposibilidad de recurrir a otros instrumentos de comunicación; pese al título del art.343 CPCCN, el texto indica que vale para llamar a personas inciertas o con domicilio ignorado y no solo a demandados en esa situación. Tampoco nos parece que corresponda dejarlo de lado en las denuncias excluyentes, pues se puede saber de la persona del pretendiente pero no de su domicilio. Entendemos que en caso de no poderse utilizar el edicto, procede la citación por radiodifusión o televisión (art.149(148) CPCCN). Sobre incomparecencia del notificado por edictos ver punto 93.

\section{Reinicio del procedimiento}

a) Reiniciación normal. El cumplimiento del plazo fijado para la comparecencia del tercero, marca el fin del de paralización del juicio. Al ser de carácter judicial es perentorio; su vencimiento significará el automático reinicio de la causa.

En un sistema como el que actualmente rige en el CPCCN, la coincidencia entre el momento de oposición de excepciones y el de contestar la demanda (art.346 primera parte) y la carga de hacerlo antes de citar, evitará que quede algún plazo pendiente que deba recomenzarse o completarse. De no seguirse ese sistema y admitirse la citación sin contestación de demanda, la paralización suspende el tiempo de responde

\footnotetext{
${ }^{361}$ Kenny Héctor Eduardo. Obra citada,pg.97. Acerca de la procedencia histórica de la citación de terceros por edictos, ver Bremberg Axel, Intervención coactiva de terceros en el proceso.L.L.80-268.
} 
que en su momento se reiniciará corriendo no un nuevo plazo total, sino los días que faltaren para completar el que fuera detenido.

b) Reiniciación anticipada. El art.81 CPC Jujuy, contempla una especial forma de dar por terminada la paralización del juicio cuando se advirtieren comportamientos dilatorios por parte del tercero ${ }^{362}$. El dispositivo puede vincularse con el art.80 en cuanto posibilita que el citado cuestione la convocatoria o el plazo conferido. Si lo hace dolosamente, con el solo propósito de prolongar la parálisis del pleito impugnando y sin argumento razonable para oponerse, la contraparte pero también el litisdenunciante no complicado en la maniobra, podrán requerir el reinicio del curso principal solución que no significa el fin de la oposición del tercero, que seguirá por trámite separado.

362 En coincidencia, Proyecto Reimundín,art.66 


\title{
CAPITULO SEXTO
}

\section{LA DENUNCIA DE LITIS Y LOS SUJETOS}

\author{
SECCION PRIMERA
}

\section{EFECTOS DE LA NOTIFICACION DE LA DENUNCIA}

\section{Efectos sobre la calidad originaria.}

La notificación de la denuncia de litis no produce consecuencias sobre el denunciante de litis que no queda liberado de su papel originario de actor o demandado y de los deberes y cargas que adquiere en su condición de tal. Como demandado y según lo dispongan las normas o corresponda según la lógica del proceso, deberá atenerse a los actos procesales que deba cumplir antes de la suspensión del juicio para retomarlo una vez reiniciado. En las litisdenuncias regresivas y extensivas, la presencia del tercero y las deficiencias o vacíos de su actuación no sirven al litisdenunciante de eximente ante la contraparte, máxime, en su caso, si se tratare de deducir las defensas que por su carácter personal no puede manejar el citado. 


\section{Efectos sobre el tercero}

Una vez notificado el tercero de la denuncia de litis, sobre su personalidad jurídica se producen, de pleno derecho, varios efectos entrelazados a saber:

1) Efecto de cosa juzgada. El sujeto notificado queda en condición de tercero obligado, y en el estado jurídico resultante del anoticiamiento formal de la denuncia de litis, de modo que, cualquiera sea la decisión que adopte, estará sometido a la cosa juzgada resultante del proceso en el que se produjo la denuncia. Al respecto habrá que tener en cuenta las modalidades que pueden darse según la clase de denuncia de litis de la que se trate.

2) Se produce el efecto de opción que permite al tercero decidir si se abstiene o concurre materialmente al juicio, en este último caso, sea interviniendo, sea planteando una pretensión excluyente .

3) Efecto de vinculación procesal. Con las modalidades correspondientes a la clase de litisdenuncia de la que se trate, el tercero, que no concurre, queda igualmente vinculado a los actos procesales que se produzcan en el juicio al que fue convocado.

4) Efecto de intreversión de roles.Como consecuencia de materializar la intervención el tercero puede convertirse en demandante o demandado según el caso. 


\section{Concurrencia: ¿opción o carga?}

El tercero es avisado de la existencia de un pleito en el que se discutirá una cuestión común. Sabe que de todos modos la cosa juzgada ha de alcanzarle. Por su poder dispositivo conservará la libertad de apreciar si sus derechos pueden quedar directa o indirectamente afectados por el proceso en el que se produjo la litisdenuncia y la sentencia que se dicte y en consecuencia, según la conclusión a la que arribe, decidirá si concurre materialmente o si se abstiene de hacerlo. Corresponderá determinar si frente a ese panorama, allegarse al juicio, es o no una carga para el tercero que, incumplida, le acarreará consecuencias desfavorables y beneficios a su eventual contraparte. Leguizamón considera la existencia de una carga de comparecencia ${ }^{363}$. Kenny, si bien no parece distinguir entre deber y carga, concluye en que producida la citación, el tercero asume una verdadera carga procesal pues dice que no concibe que sin el deber de comparecer pueda alcanzarle la sentencia ${ }^{364}$. No olvidemos que para ese autor, la denuncia de litis es una demanda de objeto declarativo ante la cual el citado se constituye en demandado y desde que resulta notificado tiene, como primera carga ,la de comparecer. Podetti sostiene que el tercero citado debe promover una tercería pues de lo contrario "la no concurrencia, el no ejercicio de la acción puede acarrear al tercero perjuicios. Es una tercería con caracteres análogos a los de la carga

\footnotetext{
${ }^{363}$ Leguisamón Héctor Eduardo. Trabajo y Revista citados, pg 210.

${ }^{364}$ Kenny Héctor Eduardo. Obra citada, pg.98 y 99
} 
procesal"365. Entendemos que en definitiva quiere significar que promover la tercería a la que alude, es una carga. Desde ya que para enfrentar la tarea referida, nos remitimos también a los conceptos expuestos en el punto 49.

Diremos que si el tercero dispone del derecho de concurrencia o abstención que podrá utilizar según su interés, no puede hablarse de la existencia de la carga de participar de la controversia común. Es claro que tal derecho debe ser ejercido en la forma prevista por el orden jurídico de modo de no afectarse el desarrollo del proceso en detrimento del actor. La ley impone un plazo para tomar la decisión y en su caso concurrir y la presencia debe formalizarse en contestación de demanda (citaciones regresivas) o en demanda (citaciones por exclusión) precisamente y en estecaso para dejar de ser tercero citado y convertirse en parte actora de su propia pretensión. De allí resulta que el tercero-parte potencial desde la notificación-no tiene la carga de ingresar pero, si decide hacerlo materializando su presencia en el juicio, debe realizarlo en el tiempo y la manera impuesta por la ley. De tal modo, cumplir con esa exigencia temporal es carga y el incumplimiento se traduce en pérdida del derecho a contestar la demanda -con ello a elegir la línea de defensa acorde con su interés- o a plantear pretensión incidental -según el caso- y a tomar el proceso en su etapa constitutiva.

${ }^{365}$ Podetti J.Ramiro.Obra citada,pg.199. 


\section{El ingreso tardío}

Como puede observarse, la ley establece que vencido el plazo fijado para decidir acerca de la participación, se produce el reinicio automático del juicio pero no que el tercero pierda el derecho a incorporarse. De tal manera, en caso de citaciones regresivas, podrá ingresar en cualquier momento posterior al vencimiento aunque deberá tomar el juicio in statu et terminis $^{\mathbf{3 6 6}}$. Por supuesto que tal ingreso lo coloca en situación de no poder elegir la línea defensiva que le convenga, pero habrá de participar de los actos procesales que pudieren restar con las facultades que teóricamente pudieran corresponder a un interviniente obligado.

Si se tratare de citaciones excluyentes el tercero no podrá ingresar demandando incidentalmente, sin perjuicio de su derecho a la vía separada y buscar la acumulación de proceso consiguiente.

\section{Efecto extensivo de la cosa juzgada}

a) Introducción. El efecto extensivo de la cosa juzgada en materia de intervención obligada de terceros, aparece establecido por el art.96(94) segunda parte CPCCN. La ley otorga al fallo firme, la virtud de trascender más allá de su alcance subjetivo natural desde que, sin resolver sobre ella,

\footnotetext{
${ }^{366}$ Esta solución está especialmente admitida por el art.27 inc.7 inc.III CPC Mendoza y está prevista en el art.84 primera parte del Proyecto Fernández. En el CPCCN figura para el garante de evicción (art.110, segunda parte, segundo párrafo )
} 
vincula a los sujetos de una relación jurídica distinta de la que fuera juzgada.

Si bien ese dispositivo se refiere a todo tipo de intervenciones de las consideradas por el código (voluntarias y obligadas), aquí no corresponde tratar sino la resultante de la citación prevista en el art.96(94) CPCCN. El dispositivo explicita la incidencia del fallo firme sobre el tercero en cuanto tal -haya o no comparecido al proceso-, de manera que no contempla la hipótesis de un sujeto convertido en demandado de la contraparte de quien produjo la citación, o en actor en virtud de ser co-obligado activo, o actor autónomo al haber reaccionado demandando ante una citación excluyente. De tal manera, el efecto extensivo en la intervención obligada se dará: 1) para el tercero citado que no haya concurrido, 2) para el tercero citado que haya concurrido manteniendo su posición tercerista, es decir no asumiendo el papel de demandado frente al actor.3) para el tercero que fue sujeto de una citación excluyente y no promovió demanda incidental o autónoma. ${ }^{367}$.

El efecto extensivo de la cosa juzgada implica que aquello que se resuelva acerca de la cuestión común, resultará válido y aplicable sin posibilidad de cuestionamiento-tanto lo referente a la prueba de hechos como a las conclusiones jurídicas que de los mismos deriven-en el eventual debate citante-citado cuando el mismo se produzca.

Con respecto a ese campo, la cosa juzgada tendrá valor determinativo-constitutivo. Determinativo (o especificativo) ${ }^{368}$ en tanto no

368 Ya se aconsejó no uniformar los efectos de la sentencia frente a los variados supuestos de intervención para respetarse así las distinciones emergentes del derecho de fondo (Martínez Hernán J. Obra citada. pg 298)

${ }^{368}$ Couture Eduardo J. Fundamentos de Derecho Procesal Civil.pg.321.Tercera edición(póstuma).Depalma .Buenos Aires.1958 
significa un pronunciamiento sobre la relación litisdenunciante tercero, sino que se limita a individualizar los elementos que en el futuro puedan servir a tal fin, declarando su valor jurídico. Constitutivo, ya que importa conformar y consolidar un presupuesto con valor prejudicial válido para operar como elemento de una acción futura.

b) Afectación y alcance. En su texto originario (Ley 17.454) el art.94,actual 96, CPCCN indicaba que el fallo "afectará" tanto al tercero como a los litigantes principales; tal expresión se mantuvo en la ley $22.434^{369}$. El uso del verbo "afectar" podía dar lugar a pensar que el efecto extensivo solamente jugaba cuando lo resuelto pudiera tener consecuencias desfavorables para el tercero pero no a la inversa. Si se tiene en cuenta el objeto de la convocatoria en las litisdenuncias regresivas y extensivasdiscutir la cuestión común y no decidir sobre la responsabilidad del citado frente al actor- se debe concluir en que el término en cuestión debía tomarse con el significado de su tercera acepción, es decir producir efectos o hacer impresión-cualquiera sea su sentido- en alguien o en algo, pero no condenar al tercero pues "afectar" no importa imponerle una prestación que deba cumplir o dejarlo en condiciones de ser ejecutado ${ }^{370}$. Así, la cosa juzgada se extendería al tercero tanto si la sentencia hubiese condenado al

\footnotetext{
${ }^{369}$ Predominan los códigos provinciales que lo siguen empleando. Ver al respecto notas 324 y 325; destacamos que el CPCC Córdoba, art.435 ,usa de la palabra "obliga" y que el término "afectará" está tomado del CPCC Jujuy que en ese aspecto, sirvió de fuente literal al CPCCN. Es también el utilizado por el Proyecto Reimundin (art.68)

${ }^{370}$ Martínez entiende que la locución "afectará" no se ve gramáticamente desvirtuada si en ciertos supuestos la sentencia de mérito se limita a ser oponible al convocado (lo que también lo afecta) en el sentido de no poseer eficacia directa contra éste...por cuanto no es ejecutable estricto sensu en su contra"( Martínez Hernán J. Obra citada,pg.299.E1 concepto de afectar no significa sino constitución de un antecedente y fundamento de una eventual acción regresiva ante la cual habrá imposibilidad de alegar defensa defectuosa (González Atilio C. Estudios ..cit.,pg.21.
} 
denunciante de litis (sentido perjudicial para el citado), como si lo hubiese liberado (sentido favorable para el tercero) ${ }^{371}$.

La ley 25.488 vigente desde mayo del año 2002 reemplazó en el art.94(actual 96) la palabras "afectará" por "alcanzará". De tal manera el texto legal concuerda con el título del artículo("Alcance de la sentencia") Nos parece que la reforma mejoró la redacción anterior aventando dudas, ya que ser alcanzado es ser incidido cualquiera sea el sentido de lo resuelto.

c) Denuncia de litis regresiva. 1. Demandado único. En las citaciones regresivas por responsabilidad cuasidelictual, tratándose de responsabilidades subjetivas, la derrota del citante frente al actor no significará la declaración de culpabilidad del tercero. Esta puede existir y en su oportunidad ser demostrada por el condenado para obtener el reembolso de lo que tuvo que pagar.

También en materia cuasi delictual y si se tratare de responsabilidad objetiva, si el demandado no alcanzó a probar la responsabilidad del tercero, será condenado a favor del demandante; pero ello no consagra cosa juzgada acerca de la inocencia del citado. Así, y como en el caso de responsabilidades subjetivas, derrotado, el demandado estará sin embargo y como principio, en condiciones de accionar de regreso contra el tercero que hubiese citado, sin que ello afecte la cosa juzgada reunida a favor de la contraparte que se formó exclusivamente en torno de la relación denunciante-citado ${ }^{372}$.

\footnotetext{
${ }^{371}$ Esa es la solución prevista expresamente por el art.103 tercera parte CPC Mendoza

372 ."Corresponde hacer lugar a la demanda impetrada por la empleadora contra el titular registral del vehículo que intervino en el siniestro y contra el principal del conductor de aquél, a fin de obtener el reintegro de las sumas abonadas a un trabajador en concepto de indemnización por accidente laboral, pues, si bien los demandados fueron citados
} 
2. Pluralidad de demandados. Puede ocurrir que el actor demande a varios sujetos considerándolos co- responsables o responsables indistintos En tal caso, la sentencia habrá de pronunciarse sobre el grado y alcance de la responsabilidad que pueda caberle a cada uno, fijando los porcentajes del daño que deberán afrontar. En esas condiciones y tratándose de condenas solidarias o in solidum o concurrentes, cualquiera de los condenados deberá responder por el total sin perjuicio de su derecho a repetir de los demás, por la parte correspondiente, solución que podrá aplicarse en la misma causa por vía de subrogación que, junto con buena doctrina, entendemos aplicable aun en las obligaciones concurrentes

3. Determinación indirecta de responsabilidades. Pensamos que, si como lo sostenemos, el fallo no puede pronunciarse sino acerca de la responsabilidad del citante frente al actor, tratándose de obligaciones solidarias o concurrentes, la sentencia deberá condenarlo exclusivamente y dejar que luego, en acción regresiva autónoma, el perdedor repita lo desembolsado utilizando de la cosa juzgada sobre la cuestión común y probando la responsabilidad de los terceros.

Sin embargo, cabe preguntarse si, apartándose del proceder clásico, a fin de evitar la multiplicación de los conflictos y de sus soluciones, cuando -tratándose siempre de obligaciones solidarias o concurrentes- existen elementos para determinar que la responsabilidad del demandado no fue

como terceros en la acción iniciada en sede laboral, la sentencia dictada en dicha sede carece de efectos de cosa juzgada respecto de la responsabilidad de tales terceros en la ocurrencia del accidente por cuanto, la intervención del tercero sólo tuvo por objeto evitar que éste pueda oponer la excepción de negligente defensa en la eventual acción rrgresiva que podía ejercer el demandado" CN.Civ.Sala M,9/11/2009.Transporte Pampeano c/Servoil y otros LL 2009-F-610 con nota de Facundo Viel Temperley "Discrecionalidad de los jueces para declarar cuando hay cosa juzgada" 
exclusiva sino compartida con aquéllos, se pueden fijar judicialmente las derivadas de distintas fuentes, o los porcentuales correspondientes a las condenas solución que permitiría al perdedor afrontar la totalidad del crédito y en la misma causa, reclamar a los terceros la restitución consiguiente .

En primer lugar vemos que si en uso de la opción de concurrencia los citados se abstuvieron de presentarse, en atención al significado atribuible a tal ausencia, la cosa juzgada solamente alcanzará a su medida clásica, es decir la declaración de responsabilidad del demandado-citante; si sobrepasando el sentido natural de la controversia el tribunal se pronunció sobre la responsabilidad de los terceros, el art.98(96) CPCCN no resulta aplicable en cuanto tal excedencia, ya que los terceros no pueden ser condenados o declarada su responsabilidad en ausencia cuando la ley les da opción para aportar o no, y no fueron llamados para otra cosa que para participar de la controversia común. De tal manera, la responsabilidad de los terceros habrá de ser debatida y fallada en la acción de regreso.

Una situación diversa se dará si medió concurrencia de los terceros citados y estos se mantuvieron y actuaron en el papel de tales y por lo tanto, dispusieron de las oportunidades necesarias como para intentar liberar al citante del reclamo actor. Al allegarse al juicio admitieron la existencia de una relación que, una vez dadas las condiciones necesarias, permitiría al citante perdedor recuperar lo desembolsado ante el demandante sin recurrir a un juicio específico. Acerca de la mecánica utilizable a tal fin y de su diferenciación con una acción de garantía, nos remitimos al punto102a y b.

d) Denuncias de litis extensivas. Si el litis denunciante pierde el juicio, el tercero no citado podrá reclamarle por los perjuicios que sufra. 
Una vez citado, la derrota del litisdenunciante no le permitirá reclamarle por los daños que estuvo en condiciones de evitar participando del pleito.

e) Denuncias de litis excluyentes. Producida la citación del tercero y si este no demanda en reivindicación de su derecho, será legítimo el pago que el demandado hiciera al actor en cumplimiento del fallo y nada podrá reclamarle el tercero sosteniendo que ha pagado mal. Si la demanda fue rechazada por falta de legitimación activa, el tercero, aun no habiendo demandado puede accionar contra el absuelto, pues el fallo no se pronunció sobre su titularidad crediticia. Si el rechazo fue por inexistencia del crédito, por la misma razón, el tercero podría accionar contra el absuelto demostrando lo contrario y la propia titularidad.El reconocimiento del derecho del demandante,no impide que el citado ausente promueva ulteriormente acción por enriquecimiento sin causa.

\section{Cosa juzgada y responsabilidades reflejas}

En los casos de demandas por responsabilidades reflejas, es factible que el actor demande al dependiente y al principal conjuntamente, configurándose así un conflicto actual a resolverse.El actor tendrá que probar,autoría y calidad de dependiente. La sentencia podrá absolver o condenar al primero y ese pronunciamiento servirá como cuestión prejudicial para involucrar al segundo en la absolución o en la condena; esta última constituirá entonces el presupuesto de la acción de regreso que el principal pueda dirigir contra el dependiente para resarcirse íntegramente una vez que haya satisfecho al demandante. 
Pero también puede ocurrir que solamente se demande al principal y éste cite a su dependiente con miras a la consiguiente acción regresiva. En ese caso y para la condena del principal, el actor tendrá que establecer los mismos extremos que en el caso anterior, pero esta vez, para tener al depedndiente no como demandado sino como mero ejecutor de la actividad de aquél. Como se ve,en este caso, el fallo habrá juzgado -si bien con el alcance señalado- la conducta del tercero rompiéndose así con la regla de la imposibilidad de establecer su responsabilidad en el pronunciamiento que hace a la cuestión común pues ello significaría admitir un juzgamiento sobre un conflicto futuro. Sin embargo, es claro que el dependiente no sería sino un instrumento del principal, de modo que en realidad se estaría juzgando la conducta de este último en el conflicto presente y no su responsabilidad ante el principal que deberá establecerse en juicio futuro.

De allí podemos preguntarnos-por lo menos en teoría- si con aquel fallo, el demandante quedó en condiciones de reclamar al dependiente, el monto de la condena prescindiendo del principal. También si tal juzgamiento habilita sin más al principal para que una vez que hubiere satisfecho al actor, pueda ejecutar al dependiente.

Con respecto al primer interrogante creemos que el dependiente puede ser condenado solo de poderse aplicar la teoría de la demandabilidad implícita (ver punto $100 \mathrm{c}$ ) o de haberse extendido la demanda en su contra de manera expresa y no fuera de tales supuestos .Si el principal no practicó la litisdenuncia, la prueba que más arriba pusimos en cabeza del demandante servirá para la condena de aquél pero no podrá alcanzar al dependiente ni como pronunciamiento declarativo. Si se produjo la citación, la condena al principal integra el efecto extensivo de la cosa 
juzgada contra el dependiente y servirá a los fines de una acción de regreso. Sin embargo, tal efecto no servirá al actor para ejecutarlo.

Solución semejante es aplicable cuando habiendo varios codemandados, la sentencia resuelva sobre los porcentajes de responsabilidad y cantidades a abonar por los principales mediante el análisis de la actuación de los dependientes. Acerca de la ejecutabilidad de una sentencia con tales características véase punto $\mathbf{1 0 2}$.

\section{SECCION SEGUNDA}

\section{LA ABSTENCIÓN DEL CITADO}

\section{Modalidades de la abstención}

a) Introducción. Llamamos abstención a la conducta del tercero cuando notificado de la denuncia de litis no concurre al pleito. Sin embargo, puede tomar actitudes de presencia distintas de, según el caso, contestar demanda o demandar. Así, puede darse que concurra constituyendo domicilio pero sin hacer manifestación alguna. También que concurra al solo efecto de dejar constancia de que se abstiene de participar o demandar por considerar improcedente o inocua la convocatoria; otra posibilidad es que se presente para plantear incidentalmente la improcedencia referida. Entendemos que se tratará de distintas maneras de abstenerse pues en tales conductas falta la actuación positiva instrumento imprescindible para considerar cumplida con la modalidad de participación 
También debe considerarse en situación de abstención al tercero que pronunciándose por tal improcedencia formula peticiones relativas al debate común ${ }^{373}$.

b) Cuestionamiento incidental. En el sistema de los arts 96(94),97 (95)y 98(96) CPCCN no se encuentra prevista la posibilidad de que el tercero citado se presente para sostener la improcedencia de la citación. La ley procesal nacional- y sus seguidoras-no contiene, en la intervención genérica, una prohibición expresa que justifique la inadmisibilidad de un planteo semejante, veda que por el contrario establece en materia de evicción mediante el art.108(106) CPCCN ${ }^{374}$. Por el contrario, aceptan la posibilidad de cuestionamiento el art.80 CPCC Jujuy, al igual que el CPCC La Rioja, por remisión de sus art. 148 al 147. También el art. 65 del Proyecto Reimundin.

En la doctrina y la jurisprudencia nacionales predomina la idea de la improcedencia de tal impugnación ${ }^{375}$. El citado no puede cuestionar la

\footnotetext{
${ }^{373}$ Precisamente, el art.305 primera parte in fine CPCC Santa Fe contiene esa idea al establecer que la incomparecencia "hará inadmisible toda alegación relacionada o que se funde en las actuaciones procesales de su eventual acreedor"- No resulta admisible negarse a intervenir pero al mismo tiempo hacer diversos planteamientos para ser resueltos en la causa ( Cám. $1^{\mathrm{a} C C}$ Mar del Plata ED 54-394)

${ }^{374} \mathrm{La}$ inadmisibilidad resulta del CPCC Santa Fe según la interpretación a contrario del art.305; la establecen expresamente el CPCC Tierra del Fuego (art.103) y su fuente el CGP de Uruguay (art.51).En esa línea, art.60 CPC de Bolivia, artículo 88 CPCC Paraguay. También resulta del art.84 parte final del Proyecto Fernández.

${ }^{375}$ Fenochietto Carlos E.-Arazi Roland.Obra citada...T.I,pg 390. Kenny Héctor E. Obra citada,pg 98. Con referencia al CPCCN y al CPC Santa Fe ,Martínez Hernán J.Procesos.. citado. T.1, pg.343. "Una vez producida la citación, el tercero no puede oponerse a la intervención decretada en el proceso por ninguna vía o recurso. Es por ello que la articulación de la defensa de falta de legitimación para obrar en la calidad en que fue convocado, no resulta admisible" (CN Fed.Civ.y Com.Sala II 4/10/91 Zeoli Carmelo c/C.N.A.S. L.L.1992-A-225.).
} 
citación pues ello significaría introducir una cuestión ajena al thema decidendum del juicio abierto entre litisdenunciante y contraparte como es el de la responsabilidad que aquél pudiera corresponderle en el evento que motivo el conflicto. Pensamos entonces que por perfecta analogía, es aplicable lo dispuesto por el art.108(106) CPCCN y tal como lo dice con respecto al tercero disconforme "su responsabilidad se establecerá en el juicio que corresponda".

Se resolvió sin embargo que el tercero puede pedir se deje sin efecto la citación, si lo hace dentro del plazo previsto por el art.240(239) CPCN para interponer reposición ${ }^{376}$, solución que pensamos es aplicable solamente en casos de errores de identificación material del tercero o bien si lo que se pretende, es obtener la contestación de demanda o cualquier otra pieza que debió acompañarla. Se ha resuelto también que puede plantear falta de legitimación pasiva, ya que de lo contrario y de conformidad con el art. 98(96) CPCCN (ley 25.488) podría ser condenado y ejecutado ${ }^{377}$. Sostenemos que no puede darse tal resultante si no hay concurrencia material (ver punto 88), o si el tercero al concurrir, (ver punto 96) no reconoce su responsabilidad y solo contesta demanda como tal sin colocarse en el papel de demandado, manteniéndose en el de tercero.

\footnotetext{
${ }^{376}$ CN Civ,Sala F.16/8/78 ,Diario El Norte s/daños y perjuicios. LL. 1979-B-665 (35.012 S)

377 Cám. Nac.Civ. Sala G. 2/13/2009, Agüero Elsa c/Federación Trabajadores de Sanidad Argentina, L.L.2009-B-64.
} 


\section{Significado y consecuencias de la abstención}

a) Significado de la abstención. El interviniente por abstención, dada su pasividad no ejercerá,obviamente,una función coadyuvante.Para atribuir valor a la conducta de abstención, será preciso tener en cuenta el tipo de denuncia de litis operada, todo sin perjuicio de la cosa juzgada que inexorablemente habrá de producirse y de su alcance. Si la litisdenuncia fuera regresiva, la incomparecencia deberá tomarse como una negativa a la atribución de responsabilidad que formulara el citante o como desinterés ante una eventual cosa juzgada por considerar que no le acarreará consecuencias, o bien, por último, como una manera de remitirse al juicio de regreso, pero nunca como una admisión de la autoría y responsabilidad que se le hubiera atribuido. Al respecto puede verse en el punto 86, el alcance de la cosa juzgada. La denuncia de litis y su notificación no importan actos de interrogación frente a los que sea exigible un pronunciamiento por parte de su destinatario. Si la denuncia es extensiva, la no concurrencia resultará neutra en lo referente a las presunciones que pudiera suscitar. De tal manera, no podrá tomarse ni como negativa ni como aceptación de la existencia de un vínculo que pudiera justificar la denuncia, ni tampoco como una renuncia a promover las acciones que de tal relación pudieran resultar.Si se tratare de una denuncia excluyente, la abstención del citado permitirá presumir, como regla general, que no coincide con el fundamento de aquélla y que no tiene derecho que sustentar ante el proceso. Ello provocará las consecuencias que, con relación a la cosa juzgada, se determinan en el punto 86 e.

b) Consecuencia de la abstención. Queda en claro que el citado no concurrente, cualquiera sea el tipo de denuncia, mantiene su condición de 
tercero vinculado al proceso con los alcance descriptos en el punto 83 y a la cosa juzgada que resulte.

\section{Abstención y rebeldía}

Doctrina y jurisprudencia consideran que el citado no es una demandado de modo que no puede aplicársele el régimen de la rebeldía ante $\mathrm{su}$ incomparecencia ${ }^{378}$. No obstante, encontramos alguna voz sustentando el criterio opuesto ${ }^{379}$ así como otras que si bien coinciden en la improcedencia de la declaración de contumacia, sostienen que ello no deriva de la inexistencia de una pretensión contra el tercero por parte del citante, que consideran está presente en la denuncia, sino de la imposibilidad de aplicarle las soluciones que resultan del estado de rebeldía ${ }^{380}$.

${ }^{378}$ Palacio Lino E. Derecho Procesal...citado, T.III pg.251; Fenochietto Carlos E- Arazi Roland. Obra citada...T.I, pgs 258 y 383. Fassi Santiago C- Yañez César D. Obra citada...T.I,pg.530. Falcón Enrique M. Tratado, citado,T.1,pg.478 “La comparecencia del tercero citado en los términos el art.94 del Cód. procesal no importa una obligación sino tan solo una facultad que, de no ser observada, tiene como consecuencia que el pronunciamiento que se dicte lo afecte al igual que los litigantes principales. Por ello y no obstante los efectos indicados, la declaración de rebeldía pretendida por el accionante no resulta procedente pues la citación no implica incorporarlo al proceso como sujeto de la pretensión o como sujeto pasivo de la pretensión regresiva eventual (CSJN 12/7/77.Entel c/Pcia de Buenos Aires. ED.121-343 no 120); Cám.Com.Sala E 26/4/1982 Banco del Interior y Buenos Aires c/Baldo Nestor E.D.121-344 no 123; CN. Civ. Sala C 30/4/1981. Maria Luis y otra c/Vorobechik Alberto y otros E.D. 95-257

${ }^{379}$ A favor de la declaración de rebeldía, lo dice expresamente el voto del Dr.Mitchell ,Cám.Civ y Com. Junín 6/10/85, J.A. 1986-IV-270,

${ }^{380}$ Kenny sostiene que resultarían inaplicables los arts. 59,60 y 63 CPCCN(arts 61,62 y 65 de lanumeración vigente) pues no se sabría qué parte puede requerir la declaración, 
Es necesario distinguir entre la rebeldía inicial y la sobreviniente y a la vez en su viabilidad según la litisdenuncia sea regresiva o extensiva por un lado o, por otro, excluyente. Si la citación es regresiva o extensiva y se tratare de rebeldía inicial, el tercero no se enfrenta con una demanda y no tiene la carga de presentarse. Algo similar ocurre en las excluyentes, pues el tercero citado tampoco tiene la de demandar o en caso contrario, manifestar que no tiene derecho para hacer valer. En ambos casos, la propia ley marca una solución distinta como lo es la aplicación de la cosa juzgada sobre el tercero, solución que desde ya permite descartar el sistema de contumacia. No cambia las cosas la circunstancia de una presentación del tercero al solo efecto de constituir domicilio o de asumir otras actitudes que permiten sostener la existencia de abstención.

En lo relativo a la rebeldía sobreviniente, en las denuncias de litis regresivas, la posición y postulaciones del tercero concurrente tendrán que generar necesariamente una resolución judicial que las considere y en su caso las evalúe, por lo que ante el abandono será preciso colocarlo en situación de rebelde con las consecuencias correspondientes (arts 61(59), 62(60) y 65(63) CPCCN),salvo el de ser directamente, sujeto de condena. En efecto, no percibimos problema en aplicarle el especial régimen de notificaciones del artículo mencionado en primer término; la presunción de verdad del art.62(62) será computada dentro del sistema de coadyuvación por concordancia (ver puntos 95,96 y 97). En las excluyentes; las cautelares del art..65 se limitarán a las costas. El tercero que concurrió y planteo su demanda incidental excluyente queda en la misma situación que cualquier

ni ante qué hechos podría aplicarse la presunción de verdad de los hechos lícitos ni trabarse precautoria pues no habría una pretensión de condena (Kenny Héctor Eduardo. Obra citada, pgs 122 a 125.) 
demandante y su abandono del proceso generará la rebeldía con similares resultantes.

\section{Inejecutabilidad}

Se trata de establecer si el tercero citado al no asumir una actitud positiva ante la notificación de la denuncia de litis, puede ser ejecutado por alguno de los litigantes originarios.Si en las regresivas no puede proceder ejecución por el demandante aunque haya concurrencia, menos podrá ser viable cuando haya abstención merced al significado que debe atribuirse a tal actitud. La condena y la consiguiente ejecución solamente podrá caber si se produjera la conversión del tercero en parte demandada, es decir fuera del régimen tercerista (al respecto ver puntos 99 y 100).

Es obvio que la respuesta también es negativa en la litisdenuncias extensivas y excluyentes ya que el tercero no es deudor del demandante.

Acerca de la posibilidad de ser ejecutado por el citante, nos remitimos a lo expuesto en el punto $\mathbf{1 0 2}$. 
SECCION TERCERA

CONCURRENCIA DEL CITADO

\section{Modalidades de concurrencia}

En materia de citaciones regresivas y excluyentes, el tercero genera una intervención obligada propiamente dicha, cuando notificado de la denuncia de litis concurre al juicio presentándose, constituyendo domicilio, acreditando representación si es del caso y contesta la demanda del actor, pero asumiendo la actitud derivada de su condición de coadyuvante, es decir sin admitir la de demandado.

Como quedó en claro, en las citaciones excluyentes el planteamiento de una pretensión de esa naturaleza genera la consiguiente acumulación de litis fuera, por ende, del ámbito de la intervención obligada.

Pensamos que así como el tercero citado tiene opción para no concurrir sin que ello cambie su condición frente a la cosa juzgada, si se presenta estando legitimado para demandar y con ello ver resuelto su derecho frente al demandado, no puede autoconvertir limitativamente su condición participando como tercero obligado ya que ello puede generar un dispendio en la actividad jurisdiccional interesada en dar solución conjunta a todas las facetas objetivas y subjetivas de un conflicto. 


\section{Intervención del defensor oficial}

Según el art.343 CPCCN corresponde que si la notificación de la demanda fuera practicada por edictos, ante la incomparecencia del demandado se designará al Defensor Oficial para que lo represente. Con respecto a extender el mismo criterio en caso de citación obligada de tercero las opiniones se encuentran divididas. Así por la procedencia de la intervención del Defensor Oficial, se inclina parte de la jurisprudencia ${ }^{\mathbf{3 8 1}}$ En la doctrina Kenny coincide en esta postura. ${ }^{382}$.

Otros fallos consideran improcedente tal intervención pues no se trata de acciones dirigidas contra el tercero ni éste, ante la incomparecencia, corre peligro de ser declarado rebelde. Por lo demás, se vulneraría su derecho de defensa al estar representado -y por ende comprometido por el fallo ante un proceso futuro-, por quien no conoce los hechos ${ }^{383}$; además, si no hay pretensión contra el tercero resulta ocioso nombrarle defensor pues al no haber reclamo no tiene necesidad de defensa. En la doctrina, Martinez acompaña esa posición ${ }^{384}$. Por supuesto que del criterio que se adopte dependerá la posibilidad de considerar o no al tercero adecuadamente notificado; pero para que se entienda que no lo está, será necesario declarar la ineptitud del sistema edictual para el caso, impugnación que no podrán

${ }^{381}$ CN Civ.Sala F 30/3/92 Miguel Juan c/Basile Cosme.L.L1992-D-1301.CN Com, Sala D,19/6/74; Líneas Aéreas Patagonia Argentina c/La Universal Cía de Argentina de Seguros. S.A.ED 58-271. Ver en nota OJO como varía su criterio).

382 Kenny Héctor E.Obra citada...pgs 97 y 98

${ }^{383}$ CN Civ.Sala A 30/11/92 Alba Jorge c/Automotores.J.A. 1993-III-519

384 Martínez Hernán J.Terceros, "Necesidad de un adecuado encuadre jurídico" J.A.1993-III-521) 
hacer los litigantes originarios pues se supone que la orden de utilizar tal instrumento se encuentra firme. A partir de allí habrá que esperar al tiempo fijado para la concurrencia y de no producirse, se generará la misma situación en la que se coloca el caso del demandado notificado por ese medio. Es cierto que el tercero citado no es un demandado, pero es llamado a participar de una controversia de las que puede resultar que lo sea en el futuro. Vemos entonces que el art.343 $\mathrm{CPCCN}$ no parte de considerar liminarmente que la notificación no cumplió con su finalidad, sino por el contrario que la logró-salvo prueba en contrario- pero que en atención a los presupuestos en las que aquella procede, es prudente brindar al demandado una protección básica y supletoria.Como la abstención no importa reconocimiento de relación de responsabilidad y la concurrencia significa lo contrario,creemos que en las litisdenuncias regresivas por analogía puede ser aplicada la solución de aquella norma y en consecuencia designar a la defensa oficial cuya labor deberá estar limitada a custodiar la adecuada interpretación de la conducta de abstención sosteniendo la improcedencia de toda condena o ejecución y procurar en tanto, la ubicación material del citado.

No ocurre lo mismo con las demás clases de denuncia de litis. En ellas, habrá que tener en cuenta que la defensoría oficial está prevista legalmente para enfrentar demandas y no para promoverlas, ya que el funcionario no puede disponer del derecho de acción del titular. Así en las extensivas promovidas por la actora y en las excluyentes, no corresponde su intervención. 
Para determinar la naturaleza jurídica de la intervención obligada de tercero con concurrencia a juicio, habrá que considerar los diversos objetivos que hemos asignado a las litisdenuncias y sus correspondientes citaciones.

a) Denuncias de litis regresivas. Ante denuncias de litis regresivas, el tercero tendrá una actuación bifronte. En efecto, asumirá una posición con respecto al citante que será inescindible de la que sostendrá frente al actor.

Ya en el tema de definir cuál es la naturaleza jurídico-procesal que corresponde asignar al tercero que participa del juicio, observamos posiciones aparentemente disimiles: una la diseñada por Chiovenda, que parece dar al tercero múltiples posibilidades, entre ellas la de ponerse del lado de la contraparte del citante integrándose litisconsorcialmente con ella o incluso apoyar a ambas (Ver en el punto 18 la transcripción de su opinión al respecto), posición que indudablemente otorga una mayor plasticidad a la figura del interviniente obligado, dando literalmente cuenta de que goza de una amplia libertad de elección para elegir caminos a transitar, pero que debe ser interpretada en sus justos alcances y a la luz del derecho $\operatorname{argentino~}^{385}$.

385 Pensamos que sus ideas no deben ser interpretadas como otorgando al citado el uso de todas las varias posturas al mismo tiempo o elegir la que más le agrade. Su rol será determinado por el tipo de denuncia de litis de la que se trate, el fundamento de la misma y el interés del citado. De lo contrario y si tomamos la opinión de Chiovenda al pie de la letra, debemos confesar que no encontramos ni entendemos cómo, en nuestro derecho-quizá pueda ser distinto es el caso de la acción de garantía italiana- el tercero puede concurrir para sustentar al mismo tiempo las postulaciones de las dos partes originarias que se supone se encuentran en pugna, salvo que se estuviera refiriendo a los 
Una segunda concepción es la que campea en la jurisprudencia en la que se presenta al interviniente obligado como un coadyuvante simple o no calificado $^{386}$.

Un tercer criterio resulta del derecho positivo que produce una asimilación práctica, y por lo menos en cuanto a posibilidades de actuación, entre la intervención obligada y la voluntaria calificada litisconsorcial ${ }^{387}$.

casos de citaciones excluyentes en los que el citado a instancias del demandado, puede coincidir con el actor en la exigibilidad del crédito y con el litisdenunciante en la falta de legitimación activa del actor, aun cuando no debe olvidarse que en esas circunstancias el tercero deja de serlo para constituirse en demandante. Tampoco encontramos que citado por uno de los litigantes pueda ingresar para defender el interés del contrario (Ver al respecto lo expuesto en el punto 95), ni que pueda proponer demandas como principal salvo que se refiera a los casos en los que, precisamente, no ingresan como terceros sino como demandantes; ni que el tercero obligado pueda reconvenir si no trae al pleito la discusión de un derecho propio supuesto no confundible con el del coobligado pasivo cuando es demandado.

386 . "La intervención del tercero en casos como éste,da lugar a la denominada adhesiva , accesoria o coadyuvante de la parte demandada,es decir,el eventual sujeto pasivo de una acción regresiva deducida por la actora,que puede intervenir en autos-si lo deseaapoyando a que triunfen las razones de la parte demandada..."CN Civ.Sala F,30/5/1980 Aristizabal Guillermo y otro c/Fernandez Adira.ED 90-497.

${ }^{387}$ En la ZPO pgfo 76 y su remisión al pgfo 61 vía pgfo 69.el citado será considerado litisconsorte. Tiene calidad de liticonsorte e igualdad de derechos que el denunciante (art. 103 CPC Perú). De litisconsorte de la parte principal lo califica el CPC Venezuela (art.381). En cambio, el CGP Uruguay ( art.51) y el CPCC Tierra del Fuego (art.103),se remiten a los derechos y cargas que correspondan según el tipo de intervención y no formulan la distinción de coadyuvantes que hace nuestro código procesal nacional. De todos modos, las leyes que no definen la calidad del interviniente obligado le otorgan plenitud de facultades procesales o señalan su autonomía o lo califican de parte, -Kenny también le atribuye condición de parte (Kenny Héctor Eduardo. Obra citada, pg.116)- nominación que en la idea clásica permite separarlo del coadyuvante simple y llevarlo a la categoría litisconsorcial. Como parte, equiparándolo a los litigantes originarios, con facultades similares a éstos, los arts.82, primera parte CPCC Jujuy, 110 del CPC Mendoza, 302 CPCC Santa Fé, 94 CPCC San Juan. 
Para abordar el tema de la naturaleza de la intervención del art.96(94) CPCCN, debemos recordar nuevamente que ella siempre será distinta de la que puede tener quién citado como tercero, deja ese rol para operar como parte sustancial de la litis y de la acción, abandonando por ende la función tercerista. Así ocurrirá si el actor amplía su demanda contra el tercero, si el tercero se coloca en el papel de demandado implícito (ver el punto 100), si el colegitimado activo no demandante, al ser citado demanda al deudor demandado y/ o a otro todavía no demandado. En otras palabras, la naturaleza referida es la que corresponde a los casos en los que el citado se mantiene en su función tercerista, resultante sea de la abstención, sea de la concurrencia al juicio. Así delimitado el tema a estudiar, corresponde comparar la naturaleza del tercero obligado con la de los otros sujetos intervinientes voluntarios o coactivos para establecer diferencias $y$ similitudes y sacar conclusiones en definitiva.

Hay semejanzas importantes entre el coadyuvante no calificado de los arts.92(90) inc. $1^{\circ}$ y 93(91) primera parte del CPCCN y el interviniente obligado del art.96(94) de ese mismo código. Ninguno de los dos pone a resolver su derecho en el pleito en el que intervienen y ambos litigan en nombre de un interés propio; no obstante, en dicho juicio se determinarán elementos y soluciones que pesarán sobre sus derechos. No pueden plantear una pretensión propia -como no sea la de ver triunfar al coadyuvado- ni siquiera reconvencional ${ }^{\mathbf{3 8 8}}$ y tampoco pueden hacerlo por el litisdenunciante, pues no disponen de su derecho de accionar. Deben ceñirse en sus respectivas posiciones al thema decidendi; en esas condiciones no pueden intervenir sino para apoyar a litigantes primitivos

\footnotetext{
${ }^{388}$ Conf.Kenny Eduardo Héctor. Obra citada, pg.121
} 
pues es ese el rol natural que les resta. Sobre ellos, pesa la cosa juzgada como consecuencia inexorable.

No obstante, se da un cúmulo de elementos de juicio que imposibilitan una asimilación de las figuras comparadas. Así, el coadyuvante simple arriba voluntariamente, en cambio el tercero obligado se ve envuelto en el litigio de manera compulsiva. Aquel puede ingresar en el proceso en cualquier momento tomándolo según su estado; este, puede hacerlo con utilidad máxima en la etapa constitutiva.

En el caso de las denuncias regresivas, el citado del art.96(94) CPCCN queda sujeto a la posibilidad de ser demandado por el actor y el riesgo de una futura acción de regreso por parte del litisdenunciante que es su acreedor eventual. El coadyuvante simple, por principio, no podrá ser demandado por el accionante actual -éste no tiene acción en su contra en cuanto coadyuvante- ni por el coadyuvado que, por el contrario, es su deudor potencial; tampoco podrá ser demandante contra el actor (por falta de acción) ni contra la parte a la que adhiere, pues todavía no tiene expedita la acción contra ésta.

El coadyuvante simple es adhesivo y subordinado al coadyuvado; de ahí que no solamente debe ajustarse al thema decidendi sino que queda sometido a la línea defensiva prefijada por el adherido y en consecuencia solo puede alegar y probar aquello que éste último puede alegar y probar y además, no puede contradecirlo. En este último sentido ninguna limitación le impone la ley al interviniente obligado en tanto mantenga una posición opositora a la del contrario del litisdenunciante al que, sin embargo, puede llegar a enfrentar usando temperamentos defensivos distintos y hasta contrapuestas, solución lógica pues la sumisión podría significar que el 
litisdenunciante lo deje inerme tanto frente al actor como ante la perspectiva de una acción de regreso.

El tercero no citado no tiene interés en ingresar como coadyuvante simple ya que por un lado, la sentencia no ha de alcanzarle y por otro,en esas condiciones la derrota de quien pudo citarlo y no lo hizo, no compromete su derecho ni como cuestión prejudicial; por lo demás, no puede hacerlo pues no es acreedor del denunciante. Una vez citado, no puede ingresar como interviniente simple pues, como se ve, carece de legitimación al efecto pues no es acreedor, y, para no quedar subordinado, conserva su calidad de interviniente obligado aun cuando ingresara tardíamente al proceso (ver al respecto el punto 85 ).

Veamos sí, descartada la coadyuvancia simple, el interviniente obligado puede ser ubicado en la calidad de litisconsorte a la manera del referido por el art.92(90) inc.2 y 93( 91) segunda parte CPCCN $^{389}$.En tal sentido vemos que en tanto ese último dispositivo califica al tercero del art.92(92) inc. $2^{\circ} \mathrm{CPCCN}$ de litisconsorte, la ley procesal nacional-distinto del caso de evicción- guarda silencio sobre la categoría que pueda corresponder al interviniente del art.96(94) CPCCN.

A poco de compararlos, el interviniente obligado una vez citado, y el litisconsorte del art.92(90)inc. $2^{\circ} \mathrm{CPCCN}$ muestran significativas coincidencias; así, no están subordinados al sujeto con el que coadyuvan y ambos son alcanzados por la cosa juzgada. El del art.92(90) CPCCN tiene legitimación resultante de su titularidad en la relación sustancial y el del art.96(98) CPCCN también, desde que la cuestión común involucra por

389 Kenny sostiene que la asimilación con esa categoría "no puede ser aceptada sin más, sino en la medida en que no se confundan ambas figuras procesales"(Kenny Héctor Eduardo. Obra citada, pg.117) 
extensión de la cosa juzgada, un derecho propio. De tal manera, si se juzga con valor prejudicial sobre aquel elemento, el tercero tiene derecho a intervenir con la misma legitimación que tendría cuando se configure la litis propia ${ }^{\mathbf{3 9 0}}$. Sin embargo, también aparecen las diferencias: así, la suerte definitiva del derecho del obligado no se juega en la prejudicalidad, en tanto que en la intervención voluntaria calificada, no hay otra oportunidad para juzgar el derecho del interviniente. A ello se suma las que hacen a voluntariedad del ingreso, al momento de intervención, a la adhesividad y a la coadyuvación, ya que con respecto a este elemento, el litisconsorte del art.92(90) inc.2 CPCCN es coadyuvante impropio mientras que el tercero obligado lo será propio, según lo vimos en el punto 9.Por lo demás, el litisconsorte dispone de su derecho y al efecto puede transar, conciliar y renunciar y también reconvenir cosas que ,como vimos no puede hacer el interviniente obligado con respecto a los derechos del litisdenunciante.

En definitiva, pensamos que la calidad del interviniente obligado tiene la misma naturaleza "genética" que la de la intervención del art.92(90) inc. $2^{\circ} \mathrm{CPCCN}$, pero muestra diferencias que impiden, como en el caso de la coadyuvación simple una asimilación total. De tal manera, debe asignársele una naturaleza propia y sui generis y en consecuencia una entidad diferenciada y exclusiva entre los sujetos procesales de modo de poder asumir condición de parte principal y autónoma, pero con una

\footnotetext{
${ }^{390}$ Nos parece que la naturaleza de la actuación del coadyuvante simple en la cuestión común con coadyuvado y contraparte, también deriva de su condición sustancial en un eventual litigio con el coadyuvado. Es claro que la legitimación no puede ser la misma que la de un interviniente obligado pues el ingreso no es promovido por el interés del coadyuvado sino por el propio interés del coadyuvante que acepta de antemano, voluntariamente actuar subordinadamente pues su interés como acreedor del coadyuvado se satisface con solo apoyarlo.
} 
legitimación de límites inherentes a la calidad y clase de coadyuvante que el derecho le asigna.

b) Denuncias de litis extensivas. Nos remitimos a lo expuesto en los puntos 42 f y 54 .

c) Denuncias de litis excluyentes. Ante una denuncia de litis excluyente, si el tercero concurre planteando su pretensión reivindicatoria del derecho, la naturaleza de su gestión no será otra que la que podría corresponderle si demandara con la consiguiente acumulación de litis, solo que en este caso podrá hacerlo pero por vía incidental. Será parte en plenitud -con la consiguiente autonomía e independencia- pero como único papel factible defenderá la viabilidad del crédito discutido si bien sustentando su propia titularidad. En esa línea de actuación no puede ser considerado tercero obligado, calidad que solamente mantendrá si se abstiene de promover una demanda excluyente .

\section{Función coadyuvante}

Siempre en el campo de las intervenciones regresivas y extensivas, vimos que la postulación que caracteriza a la intervención obligada, es la de acompañamiento al litisdenunciante coadyuvando -coadyuvación por concordancia- a su favor pero desde una posición autónoma según lo hemos visto. Tal labor tendrá que manifestarse al asumir la contestación de la demanda, oportunidad en la que el tercero tendrá que definir las líneas defensivas que adoptará al efecto y que podrán ser coincidentes o no con 
las del citante, según se detallarán en el punto siguiente. Tendrá que sustentarlas con la prueba que considere adecuadas ya que deberá asumir como parte la carga correspondiente, según el tipo de responsabilidad en discusión. El resultado de las pruebas serán adquiridas por el proceso y por ende serán computables favorezcan o no al coadyuvado. Desde ya que el tercero, al no ser demandado, no podrá alegar defensas personales ni la prescripción de la posible acción de regreso ya que su responsabilidad ante el citante no se resolverá en ese pleito.

\section{Contenido sustancial del responde}

a) Denuncias de litis regresivas . Ante ese tipo de denuncia, el tercero si concurre al proceso, contestará la demanda y al efecto podrá asumir las siguientes actitudes:

1) Comportarse como responsable y allanarse ante el actor por el total o por una parcialidad de lo reclamado.

2) Comportarse como demandado y aceptando la participación en el hecho, negar la propia responsabilidad por entender que obraron circunstancias que impiden que la demanda prospere en su contra (por ejemplo, prescripción, culpa del actor o del citante, hecho de tercero por el que no deba responder, caso fortuito ${ }^{391}$ ).

\footnotetext{
${ }^{391}$ El CCCN (art.1731) subsume el caso fortuito en la excusa absolutoria por hecho de un tercero por el que no se debe responder.
} 
3) Presentarse como tercero obligado sin hacer salvedad alguna y proceder a actuar en defensa de la posición del citante. Ello importa reconocer el vínculo obligacional con éste, a operar en caso de su derrota sin perjuicio de las defensas impeditivas que al momento de la acción de regreso pudiera oponer a la misma (por ejemplo prescripción, pago, compensación). Acerca del efecto de cosa juzgada en esta hipótesis puede verse punto 86, especialmente sub punto c.3). En lo relativo a la posibilidad del ejecución por el denunciante, ver punto 102).

Es claro que si el tercero no participó en el hecho, ni directamente ni por medio de un dependiente o bien participó pero entiende que no es responsable por tratarse de culpa ajena, carecerá quizá de interés en concurrir materialmente, pues en ese caso, la sentencia no resolverá con valor extensivo de cosa juzgada, ni sobre su participación ni sobre su responsabilidad.

b) Denuncias de litis extensivas. El citado concurrirá apoyando al litisdenunciante. De todos modos, nos remitimos a lo expresado en los puntos 54 y 55 .

c) Denuncias de litis excluyentes. Ante una denuncia de litis excluyente, repetimos que si el tercero concurre planteando su pretensión reivindicatoria del derecho en juego, la naturaleza de su gestión no será otra que la que podría corresponderle si demandara con la consiguiente acumulación de procesos, solo que en este caso podrá hacerlo pero por vía incidental. Será parte en plenitud -con la consiguiente autonomía e independencia- y sostendrá titularidad y existencia del crédito debatido 


\section{Actuación procesal}

a) Contestación de demanda. En las citaciones regresivas y extensivas, el tercero ingresante tempestivamente, asume las cargas de contestar la demanda del actor dirigida al denunciante de litis y ofrecer prueba al respecto .La existencia de tales cargas no significa que cumplidas o no, el tercero se convierta en accionado del actor, sino que resultan de su función coadyuvante y como manera de que puedan computarse al momento de sentenciar.

Si no hubo responde del demandado (recordar que sostenemos la necesidad de que se haya producido al tiempo de citar) su abstención no podrá ser cubierta válidamente por la operatoria del tercero, ya que para coadyuvar,se precisa de la postura del coadyuvado pues como lo señalamos, no es ni su representante ni su sustituto, ni puede disponer del derecho debatido.

Al no ser sujeto de la relación actor- demandado, como ya se dijo, el tercero no puede incluir en su responde la discusión sobre derechos o defensas propias ni reconvenciones.

b) Reconocimientos. Como es sabido, en toda contestación de la demanda debe asumirse las cargas de pronunciamiento del art.357(356) CPCCN. También deberá cumplirla el tercero sin perjuicio del valor que corresponda asignar a sus manifestaciones o silencios ya que por principio están referidos a actividad personal del demandado y no a la propia .

c) Excepciones. En lo referente a las excepciones de previo y especial pronunciamiento, habiéndoselas planteado por el demandado al contestar la demanda, como el pedido de citación suspendió el trámite del proceso, 
estará pendiente la sustanciación de las mismas con el actor y en su presentación el tercero podrá manifestarse al respecto. A la vez, en esa oportunidad, debe articular todas las excepciones que el demandado hubiese podido deducir salvo las personales; podrá entonces abstenerse de repetir las que ya se hubiesen planteado o reiterarlas con otra fundamentación. El juez dispondrá la sustanciación y resolverá por acumulación incidental en un solo pronunciamiento. Fuera de ello, el tercero podría deducir a título propio y sin perjuicio de su procedencia, excepción de incompetencia si estuviese aforado pero no la que en función de la persona pudiera tener el denunciante de litis.

d) Prescripción. Con respecto a la prescripción de la acción de regreso, es claro que desde nuestro enfoque y a diferencia del sostenido por Kenny $^{392}$, pensamos que el tercero no puede articular las que hagan a su posición frente al litisdenunciante sino en oportunidad de deducirse aquélla. En cambio, las facultades del interviniente obligado, como interesado, le permiten sustentar, si lo considerase adecuado, la liberatoria del citante frente al demandante si aquél no la hubiese utilizado y,en caso de citaciones extensivas, como acreedor eventual aun cuando se hubiere renunciado (art.3963 Cód.Civil; en materia de fianza, art.1587 CCCN) y de igual manera ocurrirá con las defensas que no tengan carácter personal.

e) Medios anormales de conclusión del proceso. El tercero no dispone del objeto litigioso que no es sino el debatido entre demandante y demandado. Por ende y si bien puede transar y conciliar con el accionante, en ello solo podrá comprometer su posición (por ejemplo, haciéndose cargo del crédito) pero nunca la del litisdenunciante. Al no ser ni demandante ni

${ }^{392}$ Kenny Héctor Eduardo. Obra citada, pgs 110 a 112 
demandado no puede desistir del derecho o del proceso o allanarse. $\mathrm{Si}$ dichos sujetos dieran fin al litigio por alguno de los medios anormales mencionados, caerá la razón de ser de la intervención obligada.

Con respecto a la caducidad de la instancia, es aplicable el régimen común. En cuanto a la solución del art.316(315) CPCCN cualquiera de ellos (demandado-citado) o ambos conjuntamente pueden pedir el decaimiento del proceso por pasividad del actor ${ }^{393}$. Con respecto a la segunda instancia si apelaren litisdenunciante y citado, el impulso procesal de cualquiera de ellos, salva la supervivencia del procedimiento si hubiera coincidencia en las postulaciones ( por ejemplo, si ambos sustentaran la prescripción liberatoria); pero, si fueren opuestas o diversas ( por ejemplo, uno alega la prescripción y el otro falta de legitimación )la pasividad afectará solo al recurso en el que se produjese.

f) Prueba. 1. Relación -tercero-contraparte. Al asumir la contestación de la demanda y si se tratare de responsabilidad objetiva, el tercero afrontará la carga probatoria del presupuesto de hecho de las normas que invocare como fundamento de su defensa o excepción ${ }^{394}$. Operará como parte opuesta al demandante, y como tal podrá usar los medios probatorios permitidos por el orden jurídico, salvo los que el coadyuvado tuviese vedados (por ejemplo, el tercero no podría ofrecer como testigos a los que el litisdenunciante tiene prohibido presentar conforme los límites establecidos por el art.427 CPCCN) y cuestionar las

\footnotetext{
${ }^{393} \mathrm{Si}$ el tercero puede ser ejecutado- art.96 CPCCN tercera parte-debe admitírsele su calidad de parte y en esa virtud la posibilidad de acusar caducidad de instancia (C.S.Fallos 228:2488, sentencia del 23/6/2005, Víctor Contreras y Compañía c/Provincia de Catamarca.

${ }^{394}$ Salvo que imperare otra solución derivada del sistema de cargas dinámicas -art.1735

Cód.Civil y Comercial-.
} 
que ofrezca el actor y en su momento, pedir negligencia de la que hubiese ofrecido; también repreguntar a los testigos que aquél proponga. Puede pedir la confesional del actor pero será requerido como absolvente ya que la acción, no versará sobre hechos personales del tercero, sino del demandado. Participará en el interrogatorio libre del art.416(415) CPCCN y en la testimonial podrá requerir explicaciones de conformidad con el art.438 CPCCN. Asimismo podrá intervenir en la formación de los puntos de pericia (art $460 \mathrm{CPCCN})$.

Al ser parte no puede ser propuesto como testigo. Kenny plantea el caso de la parte originaria que propuso al tercero como testigo y se encuentra con que al ser citado por el oponente queda convertido en parte. Propicia que pueda convocarlo como absolvente ${ }^{395}$. Tal supuesto se produciría si la propuesta de testimonial hubiera partido del actor y fuese el demandado quién denunciara, o si el demandado pudiendo utilizar el testimonio del sujeto citado, se viera privado del mismo por haber sido demandado por el actor. En el primer caso, habrá que tener en cuenta que la mera oferta de prueba por parte del demandante recién será resuelta con carácter constitutivo en la audiencia del art. 361(360) CPCCN ; para entonces, el demandado habrá formulado la denuncia de litis y, obtenido la constitución del tercero en citado y parte potencial. Concurriendo, al ser parte efectiva no podrá testimoniar,a diferencia de si se abstiene, atento el desinterés inherente, sin perjuicio del valor de sus dichos. La posibilidad de confesional no será practicable por no jugarse hechos personales.

2. Relación tercero-denunciante. El primer problema a resolver es si el tercero puede controlar o participar en la formación de la prueba del

\footnotetext{
${ }^{395}$ Kenny Héctor Eduardo. Obra citada , pgs. 130 y 131.
} 
litisdenunciante al que apoya. En materia testimonial pensamos que podría ampliar el interrogatorio, pedir careo, denunciar falso testimonio; de igual manera participar en la determinación de los puntos de la pericial que aquel sujeto hubiese pedido.

Kenny en su clásica obra, dice que el tercero puede pedir la absolución de posiciones de las partes principales ${ }^{396}$. Si bien ello es así en cuanto a que requiera confesional del actor, habrá que ver más detenidamente el caso del tercero obligado que pretenda someter a tal prueba al litisdenunciante con el que coadyuva. Para que eso fuere posible, denunciante y citado tendrían que ser oponentes y vemos que en nuestro caso, el tercero en definitiva, coincide con aquél en el rechazo de la demanda, coincidencia que se acentúa si no dedujo una versión defensiva distinta de la empleada por el coadyuvado; si las versiones de ambos son discrepantes, aparecería la oposición esperada pero no tendría valor frente al actor y solo serviría para el futuro juicio de regreso, de modo de no ser admisible a los fines de establecer la responsabilidad del coadyuvado frente al actor y de esa manera no integrará la cuestión común.

Como principio, el tercero no puede pedir la negligencia de la prueba del litisdenunciante ni viceversa. ${ }^{397}$. Podría ser que según las circunstancias del caso, esa regla se altere cuando la pasividad de alguno de ellos sea un obstáculo insalvable para la terminación de la causa, habiendo interés razonable en darle fin. Por analogía podría tomarse la solución del art.81 CPCC Jujuy. Otra pregunta a formular es si el tercero puede activar la prueba del denunciante y a la inversa. Sostenemos que haya o no

\footnotetext{
${ }^{396}$ Kenny Eduardo Héctor. Obra citada, pg.121

${ }^{397}$ Kenny sostiene que en nombre de la celeridad del juicio resulta posible que acuse negligencia a ambas partes (Kenny Héctor Eduardo, obra citada, pg.131)
} 
coincidencia de postulaciones, no pueden subrogarse en la iniciativa y disposición de tal actividad que sigue en cabeza exclusiva de cada sujeto.

La autonomía del tercero se pone de manifiesto en cuanto a que, si su prueba coincidiera con la del litisdenunciante, la caída por negligencia de la de este último no impedirá la producción de la del primero y a la inversa.

g) La sentencia. Formalmente el fallo que resuelva la relación denunciante de litis-contraparte se ajustará a las disposiciones de los arts.164 (163), 165(164) y 166(165) CPCCN .En cuanto a la valoración de las postulaciones de tercero y denunciante, siendo coincidentes para obstar a la demanda se valorarán en conjunto. Si las sustentaciones fueren contradictorias, se apreciarán como defensas separadas. La derrota de la del litisdenunciante no obsta al triunfo de la del tercero y con ella al rechazo de la demanda. La consideración separada no significará total abstracción del contenido y prueba de una cuando se analiza la otra.

h) Recursos .El tercero podría recurrir de toda decisión que pudiere afectarlo personalmente, como por ejemplo, las que signifiquen rechazar la incompetencia planteada como aforado. También puede hacerlo con respecto a las decisiones que afecten al coadyuvado, entre ellas, es claro, la sentencia. La omisión de esa parte en recurrir del fallo, no impide que el tercero apele, pero el consentimiento expreso de la sentencia desfavorable por parte del litigante originario cierra el camino de todo intento impugnatorio. En tal caso el citante perdedor queda expuesto a la mali defensa en el regreso, salvo que pudiere demostrar la inutilidad de recurrir (arg.art.2112 Cód.Civil; art.1048 incs b) y c) CCCN).

Es claro que el triunfo del recurso de cualquiera de las partes (denunciante o citado) obteniendo la revocación de la sentencia condenatoria se extiende a ambas, incluso aunque el tercero no hubiese 
recurrido y aun cuando los fundamentos defensivos pudieran ser diversos o contradictorios.

SECCION CUARTA

EFECTOS SOBRE EL CONCURRENTE

\section{Tipo de efectos}

Así como el tercero concurrente asume un rol en el proceso cuya naturaleza y alcances fuera explicada, su presencia en el juicio genera efectos que habrán de producirse como posibilidad utilizable por el actor: nos referimos a los que denominamos efectos de demandabilidad y efecto ejecutorio. A ellos se suma otro que resultarán naturalmente del papel que el tercero asume con respecto al denunciante: es el que llamamos efecto asociativo. 
Es harto conocido el principio según el cual-ya lo dijimos- el actor no puede ser forzado a demandar a quien no quiere hacerlo ${ }^{398}$. Con referencia a las citaciones regresivas por responsabilidades de todas las fuentes posibles, ya dijimos que ante la denuncia de litis y en cuanto ella muestre la existencia de un eventual responsable, el actor puede pasar a demandarlo expresamente, con o sin desistimiento con respecto al citante. ${ }^{399}$.También pueden darse situaciones en las que sea el propio tercero quien asuma el papel de demandado siendo aceptado como tal por el actor .Tales fenómenos forman parte del que denominamos efecto de demandabilidad. Se da entonces la conversión (interverción) del rol de tercero en parte accionada por el demandante y por ende con posibilidad de ser condenado y ejecutado por éste. Es claro que el efecto referido debe diferenciarse de la normal posibilidad del sujeto activo de plantear inicialmente su demanda contra todos los que entiende son sus legitimados pasivos. Vinculado con el tema, se encuentra la reserva que suele hacerse en el inicio de poder accionar contra la persona que se determina inicialmente o quien pudiera resultar responsable en definitiva (demandado genérico) aun cuando entendemos que no es indispensable como condición para poder practicar una extensión subjetiva de la demanda. Así y dados los casos de interversión, cesa la posibilidad de mantener al tercero como tal por la

\footnotetext{
${ }^{398}$ Debe distinguirse entre la libertad de elegir al demandado y la de litigar, ya que ésta última debe relativizarse: en efecto, el actor, siendo tal, se ve compelido a enfrentar a los terceros que voluntaria o forzadamente coadyuven con el demandado sin que necesariamente tenga que demandarlos.

${ }^{399}$ Es claro que en las litisdenuncias excluyentes no se producirá el fenómeno referido ya que el citado lo es para a asumir una pretensión como titular, es decir devenir de tercero a parte actora con exclusión de otro papel. Tampoco puede ocurrir en las denuncias de responsabilidad por contribución planteadas por el actor en las que el citado no puede sino allegarse al pleito para codemandar.
} 
incompatibilidad existente entre esa calidad y la de demandado ${ }^{400}$.Desde que se produzca el cambio de roles, la actuación del citado será la correspondiente al segundo de esos papeles ya que automáticamente queda descartado el primero. Desde ya que con la legitimación demandada, podrá reconvenir, alegar excepciones y demás defensas a título propio, sustentar compensaciones ,producir en todo caso, las correspondientes pruebas y recurrir del fallo en cuanto afecte su interés.

La demandabilidad puede concretarse de manera expresa o formal, e implícita o informal. La primera se dará en las siguientes situaciones

1) Cuando la demanda se plantea inicialmente en los términos del art.330 CPCCN.

2) Cuando se amplía subjetivamente la demanda antes de disponerse la apertura de la causa a prueba.

3) Cuando como resultado de la citación o de la contestación de la demanda, al exhibirse ante el actor la existencia de un posible responsable, aquél reajusta su demanda incluyéndolo ${ }^{401}$.

\footnotetext{
${ }^{400} \mathrm{Si}$ ya se demandó a quien se pretende citar como tercero, el llamado es inconducente pues significaría atribuirle una doble participación con el mismo contenido(CN Civ.Sala B,13/7/76 Monteiro Alvaro,Joaquín y otros c/Ocofru S.A.y otros. ED 121-395,nº147)

401 "En los casos en que el accionado pide la citación de un tercero que se encuentra legitimado para ser demandado, debe permitirse a la actora la posibilidad de ampliar su demanda incluyendo el pedido de condena contra el tercero citado, lo cual si bien importa una modificación intempestiva de los términos de la litis, permite una solución más benéfica para los interesados, en tanto asegura un tratamiento igualitario entre el actor y el tercero en cuanto a sus posibilidades rituales y se logra una simplificación
} 
4) También se dará si, aun cuando se use el término citación y no el de demanda, se exprese el propósito de sustentar una pretensión y se cumpla con los requisitos necesarios para configurar una demanda.( por ejemplo art.118, segunda parte, de la ley de seguros -ley 17.418- en cuanto el damnificado "cita" al asegurador del causante del daño).No entran por tanto en la categoría tratada, los casos en los que el actor se limita a dar conformidad para la citación pedida por el demandado o guarda silencio al respecto sin que de ello pueda extraerse una voluntad demandante.

\section{Demandabilidad implícita}

procesal que reporta un evidente provecho para la economía procesal"(CN Com. Sala A,5/6/91 Argos Cía de Seguros c/García Fernández y Cía S.R.L. ,LL 1992-B-113.). . "Si la demanda incoada en virtud de un accidente de tránsito fue contra" quien resulte propietario y/o civilmente responsable del vehículo embestidor", cabe considerar que, una vez identificada, esta persona cuyo nombre era desconocido, revestirá la calidad de demandado y será susceptible de ser condenada. Tanto más si, como en el sub judice, se le concedió la posibilidad de desenvolverse dentro del proceso con las facultades propias del accionado, v.gr. contestar la demanda y ofrecer prueba"(CN Com, Sala B 29/2/96 Martínez Angel y otra c/Selva Raúl s/sumario. LL 167 p.427).

Po la viabilidad de la ampliación de la demanda por parte de la actora, Art.93 tercera parte CPCC Entre Ríos; art.88 segunda parte CPCC La Pampa. Anteproyectos de reformas de los Dres Colombo, Cueto Rúa, Etcheverry y Umaschi ,art.99(.Ver punto 31)y de los Doctores Arazi, Kaminker, Eisner y Morello (Ver punto 31 y trabajo de Arazi citado en nota 300) 
a) Introducción. La demandabilidad implícita puede darse cuando el tercero, una vez citado y al presentarse, actúa como demandado, contesta la pretensión tal como si estuviese dirigida en su contra alegando alguna cuestión que pueda personalmente exculparlo, y es admitido como accionado desde que el actor no cuestiona la asunción de tal papel manifestando que no quiere tenerlo como tal- aunque deba soportarlo como tercero-.debate entonces con él , como si lo hubiese demandado expresamente. En esas condiciones, se admite la ficción de una pretensión dirigida al citado, en los mismos términos en los que se orientó contra el citante. De resultar una condena, la misma sería ejecutable contra dicho tercero al igual que si hubiese mediado una pretensión expresa.

b) Demandabilidad expresa. Doctrina y jurisprudencia dividen sus opiniones acerca de si, para que el actor pueda accionar contra el tercero citado por el demandado, es imprescindible la demanda formal y expresa o resulta viable, la existencia de la que llamamos implícita según la configuración que hiciéramos antes. En la doctrina, FassiYañez, son categóricos en exigir un pronunciamiento concreto del actor para que pueda caber una condena del citado, ya que de lo contrario se violaría el principio de congruencia, debiendo facilitarse al respecto la posibilidad de ampliar su demanda al respecto ${ }^{402}$. En coincidencia, Gonzalez $^{403}$. Igual temperamento siguen Fenochietto-Arazi, precisando que debe permitirse que ante la citación el demandante pueda ampliar su

\footnotetext{
${ }^{402}$ Fassi Santiago C-Yañez Cesar D. Obra citada T. I,pg.533 a 536.

${ }^{403}$ Gonzalez Atilio Carlos, Obra citada pgs 20 y 21
} 
demanda contra el tercero citado ${ }^{404}$. Por otra parte tanto Fassi-Yañez como Fenochietto -Arazi recuerdan y aplauden la propuesta aprobada por la Comisión Quinta de las Terceras Jornadas Rioplatenses de Derecho (San Isidro,1 al 3 de octubre de 1981) que propuso "Quien actúa como tercero litisconsorcial, estando legitimado para ser demandado, no puede ser condenado en la sentencia que favorece al actor que no lo demandó; no obstante debe preverse la posibilidad de que éste pueda ampliar su demanda solicitando expresamente la condena del interviniente .Arazi, ratifica ese mismo criterio ${ }^{405}$.

Paralelamente, la jurisprudencia siguió por mayoría el temperamento de exigir una demanda expresa contra el tercero como condición para poderse considerar su responsabilidad ante el actor criterio acorde con la idea de la denuncia de litis como un antecedente destinado a evitar que el convocado pueda alegar ante la acción de regreso la exceptio mali defensa ${ }^{\mathbf{4 0 6}}$.

${ }^{404}$ Fenocchietto Carlos Eduardo-Arazi Roland.Obra citada, T.I,pgs 386, 392 a 394

405 El autor expresa: "Nosotros creemos que la sentencia no puede ejecutarse contra un tercero que no ha sido demandado; aquélla debe contener la decisión expresa, positiva y precisa, de conformidad con las pretensiones deducidas en el juicio (art.163,inc. $6^{\circ}$, Cód. Procesal).Si el actor no pidió expresamente la condena contra el tercero citado, el juez no debe condenarlo, pues si procediera de otra forma estaría fallando más de lo pedido..."( Arazi Roland .La Intervención de terceros en el proceso civil, en Revista de Derecho Procesal 2006-2-pg-120.Rubinzal Culzoni Editores. Buenos Aires-Santa Fe.2006

${ }^{406}$ Así lo entendió la Corte Suprema, CSJN Fallo 360:811.Siderca S.A. c/Pcia de Misiones. L.L.1982-B-473. Esa línea fue seguida mayoritariamente por diversos tribunales inferiores inclusive por vía plenaria: CN Especial Civ. y Com. 17/9/88 Carenzo Julio c/Ortiz de Zárate Isabel L.L.-1989-A-455. Ese plenario fue reemplazado por el pronunciamiento de igual naturaleza emitido por la CN Civ.4/3/92 Balebona Manuel c/Storzi Daniel LL1992-B-264 en el que se siguió la misma tesitura, pero 
c) Demandabilidad implícita. Sin embargo, la idea de una demandabilidad implícita ganó terreno ${ }^{407}$. Igualmente en la doctrina ${ }^{408}$.

especificándose que la improcedencia de la condena abarcaba igualmente a los casos en los que el tercero citado no hubiese concurrido al juicio; Cámara Federal Civ.y Com.de la Capital en Gas del Estado c/Equimac .Plenario del 30/11/77 LL 1968-A-393 especialmente votor Dr.Muzio; CN Com.Sala A 11/2/88 Bulrich S.A. c/Elizalde Allaria y Cía LL 1988-D-334; id 15/3/94 Pirillo José s/quiebra c/Interfinanzas Cía Inmobiliaria S.A. ED 159-124.; Juzgado Nacional de $1^{\mathrm{a}}$ instancia en lo Comercial $\mathrm{n}^{\mathrm{o}} 26$ (firme) 5/12/95 Galante Bernardo c/Aerolíneas Argentinas, aun cuando por las especiales circunstancias del caso, se admitió la intervención requerida. ED 167-264; CN Fed.Civ.y Com.Sala I,4/3/94 Rivas Mario y otra c/ Gas del Estado LL 1994-D-402; id Sala II,11/6/91, Fluvialco Navegación S.A. c/ Transportes Fluviales Argerio S.A. LL 21/10/91;id 10/5/91 Dacosta Eduardo c/Estado Nacional, Secretaría de Turismo LL 1992-C-302; CN Trabajo Sala Y,30/8/93 Besone Marta c/Telecom Argentina DT 1994A-207;id Sala VIII 30/7/93. Gonzalez Carlos A.y otros c/Trovato Construcciones S.A. y otro DT 1994-B-1444. "En la citación de terceros debe distinguirse según que ella sea solicitada por el actor o por el demandado, pues en esta última hipótesis el citado no por ello ha de ser incluido en la condena, porque no se intentó ninguna acción contra él y el accionado no puede forzar al demandante a dirigir su pretensión contra el tercero" ,"salvo que pudiera existir demanda del actor o interpretarse la existencia de tal" (CN Civ.Sala D,11/11/79 Cicero Francisco c/Villar Ricardo. ED 121-341 no 93; id Sala C 22/5/84, Vitto Enrique A y otra c/Ricart de Baixadera ( es de hacer notar que en este fallo se mezcla el tema del litisconsorcio necesario con el sistema del art.94 CPCN).ED $110-443$.

${ }^{407}$ Por ejemplo CN Civil, Sala D 6/11/85 Del Plata Construcciones S.A. c/Fischman SR y otro JA 1986-IV-274.En ese fallo el Doctor Russomano, autor del voto que siguiera el resto del tribunal dijo "Para casos como el presente, en que los citados actúan en el proceso en defensa de intereses propios y controvierten las pretensiones del actor, considero que son partes demandadas en la causa, por lo que no pueden ser omitidas en la sentencia, la cual sin duda debe afectarlos como a los litigantes principales (art.96 Cód.Proc)" ;SCJ Pcia Buenos Aires 7/8/84 Bodoriquian J.R. c/Empresa Constructora Juan Strauss ED 112-180; CN Civ.Sala D 6/11/85 Del Plata Construcciones S.A. c/Fischman y otro.LL 1986-D-430.CN Com. Sala A 5/6/91 Argos Cía de Seguros c/García Fernández LL 1992-B-113.En este fallo se sostiene que como principio es improcedente la condena del citado, salvo que haya asumido un papel de verdadero codemandado. CN Trab. Sala III 27/3/89 Quiroga Armando c/Delfino Alfredo. LL 1991-C-53,con nota de Guisado Héctor César. "Transformación y ampliación de la demanda en el procedimiento laboral". Con igual criterio que el anterior y la salvedad de que debe haber sido citado por la demandada, CámFed.Civ.y Com. Sala $3^{\text {a }}$ 
d) Evolución de la Corte Suprema. Luego del fallo Siderca, mencionado más arriba, la jurisprudencia de la Corte Suprema presentó ciertas variantes. En tal sentido debe prestarse atención a la postura sustentada por el Doctor Vázquez y en definitiva a la doctrina sentada por los fallos dictados antes de la reforma introducida por la ley 25.488. Al respecto, el alto tribunal en el caso Barrio Junior S.R.L. c/Cándido Jesús Antúnez de fecha 20/8/996, (LL 1997-C-502), sostuvo con el aval de cinco de sus nueve miembros, que debía descalificarse la sentencia que no extendió la condena a los terceros citados ya que resultaría un dispendio de actividad jurisdiccional diferir para un segundo pronunciamiento un eventual desalojo teniendo en cuenta que pudieron ejercer plenamente su derecho de defensa en juicio y no lo hicieron. El resto de los jueces se inclinó por la inadmisibilidad del recurso extraordinario con lo que resultó triunfante la doctrina de la extensión del fallo sin demanda expresa. Hacemos notar que en realidad en el caso no hubo una real denuncia de litis sino una modalidad de ampliación de demanda (Ver al respecto punto 58)

31/5/91,Entel c/Hogar Obrero;CN Com.Sala B 29/2/96, Martínez Angel y otra c/Selva Raúl A.s/sumario.E.D.167-427; CN Fed.Civ.y Com. ,Sala II 16/11/95 Villamayor Julio c/A.P.S. LL 1996-B-716 (38.507 S ).id Sala III,6/12/1991.Solvencia Cía de Seguros c/capitán y/o armadores y/o propietario buque Nedlloyd y/u otro

${ }^{408}$ Colombo Carlos J. "El proceso con pluralidad de partes y las figuras procesales que lo integran” L.L.1986-D-425; Leguisamón Héctor E. "Una oportunidad perdida para condenar al tercero obligado en los accidentes de tránsito".LL1990-E-1008. "Una nueva oportunidad perdida para condenar al tercero obligado en los accidentes de tránsito. "LL1993-E-752.Wetzler Malbrán Ricardo, en "Ejecutabilidad de la sentencia contra terceros en los casos de intervención obligada" ED 111-895, "Definición a nivel plenario de los efectos de la sentencia de condena respecto del tercero citado a juicio", ED 132-815, "Nuevamente sobre la problemática de la posibilidad de condena contra el tercero a pedido de la demandada originaria” ED 188-356. El autor sostiene que salvo oposición expresa del actor, a partir de la citación, el tercero pasará a asumir el rol procesal de demandado 
Con una integración distinta resultante del ingreso de un nuevo juez en reemplazo de uno de los votantes de Barrio Junior,- en la causa Gandolfi de Vanetta fallada el 16/4/98 (Fallos 321:767),cuatro magistrados se inclinaron por considerar que mediando citación y no advirtiéndose ninguna traba al derecho de defensa, ejercido plenamente por el convocado que contestó la demanda y participó del juicio, el tercero puede ser incluido en la condena solidaria a favor del actor aun cuando éste no lo hubiese requerido específicamente. Tres sostuvieron que "el principio de congruencia procesal obsta a la posibilidad de condenar al tercero citado en los términos del art.94 (art.163 inc. 6 del mismo código) que no fue demandado". Añadieron que la citación no tiene otro objetivo que hacer que la sentencia pueda ser oponible en un eventual proceso ulterior. Dos jueces se pronunciaron por la inadmisibilidad del recurso extraordinario intentado. Entendemos que, tal como se ha considerado por la alzada federal $^{409}$, para entonces no había a nivel de Corte Suprema un criterio formado que permitiese desvirtuar, el que tradicionalmente sostuvo el alto tribunal contrario a la condena del tercero, ya que solamente cuatro sobre nueve jueces estuvieron por la extensión sin demanda expresa. Para más, mientras en el caso Barrio Junior SRL la mayoría sostuvo la posibilidad de condenar a los terceros citados aun sin demanda expresa y pese a no haber concurrido, en Gandolfi de Vanetta podría deducirse a contrario que el bloque numéricamente mayor de jueces rechazó implícitamente la idea de una condena en ausencia. Sin embargo, ya con fecha 11/5/97 en el caso Incone S.A. c/Raquel L.Ortega (E.D. 177-87), el alto tribunal había

\footnotetext{
${ }^{409}$ Siguiendo al voto del Doctor Amadeo, el tribunal sostuvo la inexistencia de un criterio definido en la Corte y se atuvo a la idea de negar la posibilidad de ejecución contra el tercero citado,CN Civ y Com. Federal, Sala III,16/12/99 Avellaneda Cooperativa de Seguros Ltda. c/capitán y/o armadores y/o propietarios buque Prosperity s/faltante y/o avería de carga. Transporte marítimo, ED 188-357.
} 
admitido que estando asegurado el derecho de defensa, era factible condenar al tercero citado tal como si fuera demandado.

e) Opinión propia. Conviene dejar sentado que entendemos que, estrictamente, la pretensión no puede ser sino un instrumento de la actora, expresado básicamente en la demanda, en tanto que la demandada -salvo que devenida en actora reconvenga o abra un incidente- titulariza la defensa formalizada en la contestación de la demanda o en su caso de un planteo incidental. Así como la pretensión victoriosa permite pronunciamientos declarativo-positivos que conlleven condenas, la defensa únicamente puede provocar decisiones declarativo-negativas que solamente implican absoluciones. De tal manera condenar al tercero sin pretensión dirigida en su contra resulta un disvalor jurídico que claramente escapa al principio de congruencia (arts.34 inc.4 y 164(163) inc.5, CPCCN) que tiene como eje y pivote, demanda y reconvención, que son las piezas que marcan los límites de la cuestión litigiosa y ante los cuales-correspondiéndose con ellosjuega la defensa para lograr la absolución propia y no la condena de otro y menos de un tercero. No salva la cuestión el jus superviniens (art.164(163) in.6 $\mathrm{CPCCN}$ ) pues los hechos a los que se refiere y resultan computables hasta de oficio, no cambian el sentido y misión de aquellas piezas, ni introducen otras distintas, de modo que siempre tendrán que estar referidos a dichas postulaciones. En otras palabras, los hechos sobrevinientes son computables en tanto constituyan basamento fáctico de pretensiones y defensas anteriores.

De todas maneras y como lo venimos haciendo, debemos distinguir los casos de denuncias de litis regresivas y extensivas, de los correspondientes a las excluyentes. 
Con respecto a las dos primeras, la idea de la demandabilidad implícita es inaplicable -es obvio- cuando el actor manifiesta que no quiere accionar contra el tercero. Tampoco puede serlo cuando guarda silencio al respecto y el citado no se presenta, pues en tal caso, a la actitud del primero sumamos la del segundo que no expresa su idea de tenerse por demandado.

Pensamos que el sistema procesalmente correcto es el de la demandabilidad expresa, aplicado con la latitud necesaria como para no ser manejado con un criterio excesivamente formalista de modo tal que puedan tener cabida, como lo hacemos, los supuestos que señalamos en los puntos 99 y 100 b. Claro que la demandabilidad implícita es aceptable al no quedar dudas de cuál es la voluntad real del actor, situación que ocurre, por ejemplo,en las regresivas, cuando es el citado quien asume por sí el papel de demandado y contesta la demanda sin negar participación en el evento, comportándose no ya en defensa de la posición del expresamente demandado, sino en defensa propia y siempre que ante tal situación, el demandante lo acepte expresa o tácitamente como tal ,o lo admita en el debate o tratándose de extensivas tuviera acción contra aquél.

El planteamiento de una pretensión contra el tercero luego de la demanda contra el litisdenunciante, no está prohibido ni resulta antijurídico Lo que no puede cambiarse a partir de la notificación, es la demanda dirigida al notificado, pero no habría inconveniente en agregar un demandado recién descubierto siempre que ello no la altere ni el proceso se desordene ${ }^{410}$.

\footnotetext{
410 . "En todo caso, como lo hemos anticipado, podría preverse las posibilidad de que el actor, al contestar el pedido de citación formulado por el demandado, amplíe la demanda contra el tercero citado si este está legitimado para ser demandado; entonces se convertiría en codemandado" Arazi Roland, Trabajo citado en nota 406, pg. 120.
} 
Estimamos, por otra parte, que hace a los deberes del juez como director del proceso, promover las aclaraciones necesarias como para aventar cualquier duda acerca de la relación demandante-citado, y en consecuencia, reconducir formalmente la causa.

En las excluyentes, la ausencia de una pretensión deducida por el tercero imposibilita que se lo pueda tener como actor: el principio dispositivo veda que su voluntad sea reemplazada por la interpretación del juez sobre sus intenciones, teniéndole por demandante cuando no expresó su propósito al respecto ni lo sustentó de manera alguna. Tampoco se lo puede tener como demandado precisamente porque ella solo sirve para que pueda demandar si se considerara con derecho a hacerlo.

\section{Efecto ejecutorio. La ley 25.488}

a) Concepto. El efecto ejecutorio es connatural a las sentencias de condena y por tanto operará contra el demandado derrotado en el juicio, así como contra el citado devenido en demandado expresa o implícitamente

La denuncia de litis que como vimos, no es una pretensión dirigida contra ese sujeto, no puede justificar una condena, salvo que, como ocurre en el derecho italiano, pudiera acumularse la acción de garantía, solución que sostuvimos no es aplicable en el sistema argentino.

La ley 25.488 agregó al primitivo texto del actual art.98(94) CPCCN, una nueva norma-su tercera parte- por la que, ante la citación, se declara posible la ejecución de la sentencia contra el tercero, salvo que éste 
alegare fundadamente que tal solución no resulta viable por tenerse que dilucidar defensas o derechos que no pueden discutirse en ese pleito. Nada dice ni exige la ley acerca de la necesidad de que las partes -contraparte o denunciante- expresen de alguna manera una pretensión, se precise juzgar expresamente la conducta del tercero o si se hace menester un fallo que lo incluya formal y nominalmente.

b) Doctrina y jurisprudencia. El dispositivo en cuestión ha dado lugar a diversas interpretaciones: la opinión predominante entiende que la ley habilitó a considerar ejecutable contra el citado y a favor del actor, la sentencia de condena lograda en el juicio en el que se produjo la citación.

Así Palacio y Kielmanovich aceptan que con la reforma pueda ejecutarse por el actor vencedor en todo caso, salvo que el tercero alegue defensas de carácter estrictamente personal (por ejemplo, no ser dependiente del principal demandado) que no puedan ser resueltas en el pleito en el que tuvo lugar la citación ${ }^{411}$; Gozaini, coincidiendo, expresa que "con el agregado efectuado al art.96 se resuelve la ejecutabilidad de la sentencia contra el tercero traído al proceso por cualquiera de las partes, aunque la excepción para la procedencia queda inmersa en una absoluta incertidumbre pues la excusa exculpatoria de defensa o derechos que no pueden ser materia de debate y decisión en ese juicio tiene tal amplitud que no se comprende dónde podría estar la dificultad para sobrellevar el derecho de defensa en juicio ${ }^{412}$; en esa misma línea Giannini dice que basta

\footnotetext{
${ }^{411}$ Palacio Lino E. Anotaciones para una explicación de la reforma procesal civil y comercial (ley 25.488) LL 2002-A-1178 y obra citada t.III, pg.215. Kielmanovich Jorge, Comentario sobre la ley 25.488 de reformas al Código Procesal Civil y Comercial de la Nación, ADLA LXI-E-6591

${ }^{412}$ Gozaini Osvaldo A.Comentarios a la ley 25.488 de reformas al Código Procesal Civil y Comercial de la Nación. ADLA LXI-E-6571
} 
que la demandada pida que la condena se extienda contra el citado para que la sentencia lo incluya en tal sentido, salvo que el tercero pueda alegar fundadamente alguna defensa o excepción que no pudiera debatirse en ese juicio $^{413}$. Falcón parece coincidir con esa posición desde que entiende que el citado al ingresar al proceso está contestando la demanda del actorcontraparte del citante- y es en esa oportunidad en la que debe alegar la existencia de defensas que no pueden dilucidarse en esa causa ${ }^{414}$. Es terminante al decir que el apartado tercero no deja duda," de que la citación del tercero importa extender la pretensión contra el mismo ${ }^{415}$. Leguisamón también afirma que "el demandado es quien, mediante el pedido de intervención, provoca que se la haga extensiva al tercero la relación procesal originaria y con ello la pretensión del actor" que permitirá la condena y la eventual ejecución si se probare su responsabilidad ${ }^{\mathbf{4 1 6}} \mathrm{y} \sin$ que sea preciso que el citante resulte condenado ${ }^{417}$. Menos contundentes, Ricardo A.Ostrower y Santiago Soria luego de señalar la poca claridad de la nueva norma, dicen que la posibilidad de ejecución contra el tercero dependerá de que pueda ser condenado en el juicio “cuestión que por cierto no es pacífica y que depende en gran medida de las circunstancias de cada

${ }^{413}$ Giannini Leandro J. El alcance de la sentencia para terceros .A la Luz de la reforma del CPCN) L L 2002-F-1122.

414 )Falcón Enrique M. Intervención de terceros, en Revista de Derecho Procesal 2006-2 pg.515.Rubinzal-Culzoni.Santa Fe.2006

${ }^{415}$ Falcón Enrique M. Cód.citado,t.I,pg 838,Lexis Nexis-Abeledo Perrot

${ }^{416}$ Leguisamón Héctor Eduardo. La intervención del tercero obligado y la ejecutabilidad de la sentencia a su respecto. Revista de Derecho Procesal 2006-2 pg.214.RubinzalCulzoni. Santa Fe.2006

417 Leguisamón Hector Eduardo.La condena al tercero en la reforma de la ley 25.488. Necesidad de un nuevo fallo plenario. LL 2004-B-1313 
caso.. ${ }^{\text {418 }}$. En cambio Arazi-Rojas critican la reforma señalando que no les satisface "porque contradice los principios de congruencia e igualdad y las normas generales del proceso, entre éstas las referidas a las costas... Solo debiera admitirse la condena cuando el actor, al contestar el pedido de citación formulado por el demandado, se adhiere y solicita expresamente la condena, asumiendo el carácter de demandante con todas las cargas y obligaciones que ello implica"419.

La jurisprudencia se inclina por la ejecutabilidad siempre que el tercero haya tenido posibilidad de controvertir al actor y ejercitar adecuadamente el derecho de defensa ${ }^{\mathbf{4 2 0}}$.

\section{Significado de la tercera parte del art.98 CPCCN}

\footnotetext{
418 Ostrower Ricardo A. y Soria Santiago. Reforma al Código Procesal Civil y Comercial de la Nación .Comentarios generales a la reforma. LL 2002-A-1079

419 Arazi Roland-Rojas Jorge A. Obra citada. Segunda edición,T.I,p.451.Santa Fé.2007

${ }^{420}$ Fed.Civ. y Com.Sala II 13/8/2013 A.D.E. c/Sanatorio Mitre,E.D.256-438.Id Sala III,10/8/2010 Cianciulli Santiago C/Alas Argentinas SRL,LL Rep.LXX,pg.788,nº15. ;CN Civ.,Sala K,28/4/2005 Gonzalez Gloria c/Basilio Largbeit. LL 2005-C-367.En este fallo el Doctor Molina Portela expreso que el traído como tercero no debe ser incluido en la condena pero puede ser ejecutado por la tercera parte del art.96(94) CPCCN, "pero previa petición concreta del sujeto activo" beneficiado por el fallo.
}

En Pcia de Buenos Aires y no obstante el texto del art.96(94) CPCC,Cám.Civ. y Com La Matanza, Sala I,27/5/2004 Echegaray Roberto c/Wal Mar Argentina LL Buenos Aires 2004-2007 
a). Nuestra opinión El art. 98(96) tercera parte $\mathrm{CPCCN}$, con una redacción realmente complicada, trata el tema de la ejecutabilidad de la sentencia incluyendo en un mismo espacio los casos de intervención voluntaria y los resultantes de la denuncia de litis. Resulta muy claro que en materia de ejecución de fallo contra el tercero,-salvo el tema de costassolo pueden estar comprendidos los casos de intervención obligada y dentro de ellos, los que se corresponden con la denuncias de litis regresivas. El problema real del dispositivo comentado es determinar si la posibilidad de ejecución está establecida en beneficio del demandante o por el contrario del litisdenunciante.

Si pensamos en la ejecutoriedad a favor del actor contraparte del litisdenunciante, tendremos que forzar la literalidad de las palabras ("contestar la citación") e interpretarlas como "contestar la demanda", total, hasta en la ley de seguros se usa el término citación como sinónimo de demanda. Por el contrario, lo lógico es aceptar el sentido literal de la ley en tanto encaje en una construcción jurídicamente armónica.

Ya en el tema de la aplicación del sistema, vemos que si se tratare de una solución consistente en extender contra el citado y sin más, la sentencia de condena al demandado, una salida semejante resultaría de palmaria inconstitucionalidad por violación al derecho de defensa del tercero, pues nadie puede ser condenado sin una instancia inicial de parte legitimada para pedirlo, luego de un proceso adecuado, y después de una sentencia que lo incluyese expresamente. El mismo vicio tendría considerando el derecho de defensa en juicio, si la sola citación pudiera transformar al sujeto citado en demandado, forzando el desenvolvimiento de un litigio con el actor, pues debe tenerse en cuenta que éste, aparte de no poder obligársele a demandar a quien no quiere, si acepta hacerlo, puede 
precisar de un reajuste de los fundamentos fácticos y jurídicos de su demanda para dirigir -correctamente y con posibilidades de éxito- una pretensión contra el tercero, que, por su lado, necesitará de tal reajuste para poder defenderse adecuadamente y asumir las cargas del caso.

Si por obra de la ley o por la decisión del demandado, el tercero se viera colocado en condición de accionado frente al actor, se alteraría totalmente el sistema del código y la naturaleza de la convocatoria pues el tercero perdería la posibilidad de optar entre concurrir o no concurrir al juicio, ya que no hacerlo lo llevaría a una situación de rebeldía. Además y con respecto a la alegación obstativa de cuestiones a resolver mencionada en la parte final del artículo, en un debate entre el actor y el tercero devenido en demandado, ¿qué mejor oportunidad para dar solución a todas las cuestiones que pudieran relacionarse con el litigio? o en otras palabras, $i$ qué cuestiones son las que no se podrían tratar en esa oportunidad? problema al que la doctrina no encuentra una respuesta consistente. Lo real es que el texto agregado por la ley 25.488 no tiene nada que permita inferir que apunta a ese norte.

Nos parece que el texto que comentamos supera, por estar ya admitido jurisprudencialmente, el tema de lo que llamamos demandabilidad implícita o obviamente el de la condena contra varios demandados en obligaciones solidarias o concurrentes, ante la cual, quien de ellos afrontara la totalidad del crédito, se subrogará al demandante para accionar contra los otros. En cambio, contempla el caso de los terceros -también en obligaciones solidaria o concurrentes- cuya responsabilidad se ha determinado al solo efecto de reducir la del demandado, pero sin que haya habido una condena específica pues no han sido accionados ni expresa ni implícitamente por el actor, caso en el que quien de los condenados hubiese 
asumido el pago total tendrá derecho a subrogarse al demandante contra los otros condenados. A diferencia de tal supuesto y para el que estamos tratando, la ley recurre a un mecanismo especial según veremos.

Antes de la vigencia de la ley 25.488 ya había una línea jurisprudencial que venía anticipando la solución adoptada ese ordenamiento: así el fallo de la Sala III de la Cámara Nacional de Apelaciones Civil y Comercial Federal, recaído el 31/8/99 en la causa Marinic Rodolfo c/Banco Río de la Plata y otro (J.A.2000-III-257 221 . También se recuerda que la doctora Highton de Nolasco-actual integrante de la CS, había seguido siempre esa tesitura en sus intervenciones en los tribunales inferiores y se dice de la viabilidad de tal criterio ${ }^{\mathbf{4 2 2}}$.

\footnotetext{
${ }^{421}$ En el caso, la actora demandó por daños y perjuicios al banco y a su asegurador: la demandada pidió la citación como tercero del Estado Nacional (Policia Federal) .El juez condenó a los demandados pero no al tercero y de esa circunstancia apeló la aseguradora. La alzada, por el voto del juez de las Carreras, sostuvo que comprobado que el tercero había tenido amplia posibilidad de defenderse, nada impedía que se determinara su responsabilidad en el evento, fijándola en un 50\%; a partir de allí y confirmada la sentencia condenatoria por el total contra el banco y su seguro, dispuso que en el mismo juicio, pudieran repetir del tercero aquél porcentaje. El mismo tribunal dispuso algo semejante especificando que la restitución debiera hacerse en el trámite de ejecución de condena (fallo del 14/12/99 causa Alianza Ras Cía Argentina de Seguros c/Merzario SRL (LL 2000-C-901 (42654 S).
}

422، Sin embargo nada obstaría a que en el mismo expediente en el que se tramitó el juicio principal, el demandado pudiera repetir del tercero la parte correspondiente en el supuesto de concurrencia de responsabilidades o que el actor pudiera subrogarse en los derechos del demandado, es decir que aunque el tercero no debe ser incluido en la sentencia condenatoria, ello no es óbice para que el demandado vencido pueda reclamarle la contribución que corresponda en la etapa de ejecución de sentencia en el mismo juicio" (Código Procesal Civil y Comercial de la Nación. Concordado con los códigos procesales provinciales. Análisis de Doctrina y Jurisprudencia. Elena H. Highton-Beatriz A. Areán. Directoras,T.2,pg.421,Hammurabi.Buenos Aires. 2004. Capítulo VIII Intervención de terceros por Susana Lambois 
Volviendo a la tercera parte del art.98(96) CPCCN y a la literalidad de sus términos, si el tercero debe contestar la citación, es claro que la ley está computando la relación litisdenunciante-tercero, pues con respecto a ella es que se suscitó la denuncia de litis. Es entonces cuando adquiere sentido que el tercero pueda alegar la existencia de cuestiones que impidan que la sentencia, aparte de su efecto extensivo de cosa juzgada sobre la cuestión común, pueda resolver sobre extremos que deban debatirse en otro juicio (por ejemplo, compensación de daños, prejudicialidad penal, prescripción del crédito del denunciante en su contra y en general, defensas impeditivas del cobro pedido ) ya que la ley, quiso posibilitar una solución regresiva para el denunciante, pero no una extensión indebida del contenido de la cosa juzgada y mucho menos, complicar la buena marcha del proceso con temas de debate totalmente ajenos al actor.

Para que la ley tenga el alcance que le estamos atribuyendo, se hace menester que se asegure al tercero un pleno derecho de defensa y se concrete una decisión judicial que lo obligue .Todo ello impone que medie un pedido formal o claramente implícito, -pero no una demanda del denunciante- para que la sentencia se extienda sobre su relación y que sea transmitido al tercero con la citación, de modo que este sepa a qué atenerse, decida si se presenta o no y pueda alegar la existencia de cuestiones impeditivas. Ante el pedido del denunciante, el tercero solamente podrá alegar fundadamente aquéllas cuestiones, pero no impugnar la procedencia de la citación en sí misma. Esa limitación no afecta el derecho de defensa del tercero citado pues no olvidemos que si se presenta es porque está admitiendo la existencia de su obligación resarcitoria frente al citante para el caso de que éste resulte perdedor; por ende, el tema está fuera de discusión; por eso es que basta con que pueda debatir con el actor 
libremente, en calidad de interviniente obligado y sin sujeción al denunciante, la procedencia de la demanda contra éste.

Ello demuestra y justifica que el litisdenunciante no tenga ni sea procedente que deduzca una demanda contra el tercero y baste con que requiera se disponga el pago, pues la obligación de resarcimiento al denunciante ante su derrota, resulta reconocida por la presentación del tercero enfrentando al actor y no precisa de pronunciamiento expreso. Ante la derrota referida-cuestión común con efecto extensible de cosa juzgada- y aquél reconocimiento, la obligación de restituir al citante pasa a tener vigencia. El mismo efecto de cosa juzgada (art.98(96)CPCCN) hace inobjetables los porcentajes de responsabilidad que se hubieren establecido. La petición del derrotado y la falta de oposición válida por parte del tercero permite que el juez determine la viabilidad de su cobro por ejecución de sentencia. El pago total por parte del denunciante, motoriza su actividad subrogatoria .

El tercero deberá pronunciarse fundadamente, es decir mostrándole al juez lo claro, cuando no manifiesto, de la imposibilidad de incorporar en el fallo, la condena de regreso. Tal exigencia apunta a no traer al juicio debates o pruebas que entorpezcan la pronta resolución del juicio perjudicando al actor, de manera que como principio no se aceptará formación de incidente alguno al respecto. De ahí que siendo fundada la manifestación o en la duda, la restitución deberá buscarse en una acción regresiva autónoma, solución que no causa gravamen irreparable al litis denunciante. No habiendo oposición del tercero al presentarse, la restitución se ordenará en la sentencia y deberá concretarse en la etapa de ejecución luego de desinteresarse al actor por parte del demandado perdedor. De todas maneras, y aun cuando el tercero no oponga objeciones, 
el juez deberá controlar oficiosamente la admisibilidad del pedido del denunciante para evitar las complicaciones a las que aludíamos antes.

Ahora bien: la solución de la tercera parte del art.98(96) CPCCN no es de total amplitud pues aparte de no ser aplicable cuando fundadamente el tercero plantea la imposibildad de ser ejecutado en esa causa ,tampoco lo será en los casos en los que el tercero citado no se presenta ante la citación. Atento el significado de la abstención (ver punto 89) aunque el fallo hubiere fijado porcentuales de culpa atribuibles al tercero frente al actor, al exceder el contenido de la cuestión común no puede obligarlo y como en el caso anterior, la sentencia servirá de punto de partida para la acción de regreso $^{423}$.

b) La acción de garantía y la solución del CPCCN. Es evidente que sin que se haya producido un vuelco total en el instituto de la intervención obligada -cosa que hubiese requerido de una decisión legislativa de mayor claridad y contundencia- a partir de la reforma del art.98(96) CPCCN se implementó un nuevo sistema que tiende a evitar el dispendio significado por una regresiva ulterior ${ }^{424}$.

Debe quedar en claro que no se ha establecido una acción de garantía a la manera italiana. Más bien una solución que se acerca a las normativas de

\footnotetext{
${ }^{423}$ Es cierto que de ese modo la posibilidad de obtener un reintegro sin recurrir a una acción autónoma queda en manos del tercero al que le bastará con no presentarse, pero es que la opción de concurrencia es derecho básico en el instituto de la intervención obligada. Como contrapartida el efecto extensivo de la cosa juzgada le será indiscutiblemente aplicado.

${ }^{424}$ Falcón se pregunta si la tercera parte del art.96-actual 98-abre o no la procedencia de una declaración de rebeldía (Falcón Enrique M.Código...Rubinzal-Culzoni,t.1 pg.448) posibilidad que nuestro razonamiento permite descartar.
} 
Colombia o Perú, pero, fundamentalmente se trata de una salida práctica y con caracteres propios.

Con la acción de garantía la diferencia se da fundamentalmente porque estamos en el campo de la denuncia genérica, es decir el de la garantía simple y no en el de la garantía formal que es el que se corresponde, según calificada doctrina, con aquella. Por otro lado, la tercera parte del art.98(96) CPCCN no parece dejar espacio para que pueda generarse alguna cuestión de competencia-factible en la acción de garantía- sino que más bien muestra al resarcimiento como un problema incidental.

Además porque la finalidad de la acción de garantía es distinta de la que se corresponde con el mecanismo que explicáramos para la ejecución. Así, la acción opera cuando el tercero se niega a asumir la defensa del citante y mediante ella se busca obtener un fallo que establezca la vigencia de esa obligación y condene al tercero a satisfacerlo de modo que por ese pronunciamiento se consagra el derecho de resarcimiento del perdedor; en cambio, el procedimiento del $\mathrm{CPCCN}$, tal como se explicó, parte de una situación contraria, como lo es la inexistencia de conflicto entre litisdenuciante perdedor y tercero en cuanto a la obligación de resarcimiento restitutivo del segundo a favor del primero.

Obviamente que para obtener sentencia en la acción de garantía, se precisa de una pretensión formalmente expresada y de la dilucidación de la colisión entre partes mediante todo un proceso, en tanto que para la solución de la ley nacional solo hace falta de la verificación de un determinado estado de cosas en la relación denunciante-citado y un pronunciamiento formal al respecto.

Por fin y con relación a los conceptos que expusiéramos en el punto $\mathbf{3}$, señalaremos que con el art.98 (96) tercera parte CPCCN no se está 
resolviendo un conflicto eventual -tal como ocurre en la acción de garantíasino considerando una situación de coincidencia presente entre demandante-litisdenunciante y tercero.

\section{Efecto asociativo}

a) El litisconsorcio. Como sostenemos la idea-que en realidad resulta de la propia elaboración doctrinaria y normativa comparada - según la cual la intervención obligada de tercero genera una modalidad de litisconsorcio, haremos una breve incursión en esa figura.

Pensamos que habrá litisconsorcio cuando en un proceso una pluralidad de sujetos actúa vinculados por relaciones que les permitan obrar en comunidad de postulación con miras a obtener un logro coincidente. Tal logro puede ser total o parcial de modo que para ser litisconsorte no se impone que la coincidencia se dé en todos los aspectos de los requerimientos que formulen ${ }^{425}$. Por otra parte, ya Calamandrei nos alertaba acerca de la naturaleza dinámica de la figura ${ }^{\mathbf{4 2 6}}$ de manera que

\footnotetext{
${ }^{425}$ Así por ejemplo pueden ser litisconsortes asegurado y asegurador en cuanto coincidan en el alcance cualitativo o cuantitativo de la cobertura, sin perjuicio de que dejen de serlo y hasta discrepen en cuanto el asegurado pretenda una protección de mayor envergadura

426 "no es posible distinguir , dentro del proceso, como puestos frente a frente, en dos campos nítidamente delimitados, de una parte a todos los actores y de la otra a todos los demandados: las relaciones de contradicción se entrecruzan y se contraponen entre las distintas parejas correspondientes a las distintas demandas, y en lugar de un solo encuentro general en un frente único, el proceso se escinde en otros de tantos contradictorios de parejas distintas, en los cuales cada litisconsorte puede encontrarse, ya como aliado, ya como adversario de cada uno de los otros" Calamandrei Piero. Instituciones,cit.t.II,pg.309
} 
advertidos del posible entramado de coetáneas relaciones de coincidencia y divergencias entre los componentes subjetivos, no atamos, como lo hace la doctrina clásica, exclusivamente el concepto de litisconsorcio al de pertenencia a la misma o conexa relación jurídica sustancial que se esté debatiendo, sino que lo extendemos a los casos en que lo resuelto con respecto a tal pertenencia alcance, con fuerza de cosa juzgada, el interés protegible de un tercero. Serán entonces litisconsortes aquéllos que, legitimados para operar en el proceso, tengan una relación de coincidencia con respecto al contenido del producto jurisdiccional que quieran obtener (una sentencia definitiva, una interlocutoria o hasta una providencia simple); y dejarán de serlo en cuanto difieran en ello; así el litisconsorcio podrá estar presente con respecto a un pronunciamiento incidental y al tiempo, ausente en lo concerniente al fallo sobre lo principal, si bien en definitiva, la coincidencia en este último aspecto, indicará la presencia litisconsorcial fundamental, no obstante la discordancia en aspectos incidentales. El campo que ocupen en el proceso con respecto a la pretensión principal (actor o demandado) no será determinante; servirá para una manera de clasificarlos, pero lo importante es la coincidencia marcada: podría haber litisconsorcio entre situados en espacios opuestos-si por ejemplo confluyeren en la obtención de una sentencia interlocutoria-así como no lo habrá si se diera oposición entre habitantes del mismo sector. La coincidencia no se rompe si los sujetos difieren en los argumentos de sustentación. Lo decisivo es establecer si lo que se requiere en coincidencia satisfacera, de ser concedido, los intereses de todos los peticionantes acordes ${ }^{427}$. Ahora bien: la coincidencia en la obtención de un

\footnotetext{
${ }^{427}$ Por ejemplo, no habrá litisconsorcio por más que los dos codemandados pidan el rechazo de la demanda resarcitoria, si las defensas se imputan recíprocamente la
} 
pronunciamiento judicial de esas características, no significa que en todos los casos, los objetivos mediatos serán los mismos sino que podrán variar en función del interés de cada integrante; así, para unos -titulares del derecho sustancial en litigio- trascenderán directamente sobre sus derechos; para otros, no titulares de éstos, tendrán incidencia indirecta sobre los derechos propios.

Existen diversos parámetros capaces de generar distintas clasificaciones de litisconsorcios (por campo ocupado, por el momento de formación, por su duración etc.) pero para seguir una pauta clasificatoria señalada expresamente por las leyes procesales, tendremos que computar el grado de libre albedrío que puedan tener los sujetos en cuanto a participar litisconsorcialmente en el juicio. Ello nos lleva a la conocida y básica distinción entre litisconsorcios voluntarios y coactivos. Los primeros se forman por la libre decisión de operar litisconsorcialmente y es tal decisión la que los vincula con el proceso. Los dividimos en facultativos (que bien puede ser inicial (art.90 (88) CPCCN) o por intervención de terceros (arts.92 (90), inciso $2^{\circ}$ y 93(91) segunda parte CPCCN) y por coadyuvación (art.92(90) inc. $^{\mathrm{o}}$ y 93(91) primera parte $\mathrm{CPCCN}$ ). El coadyuvante simple está reconocido como parte en el CPCCN precisamente en razón del interés que resulta del efecto que la sentencia puede tener sobre su derecho, aunque ello no vaya a resolverse por tal pronunciamiento. Sostenemos que se integra en litisconsorcio -de características sui generis- con el coadyuvado en cuanto postulan la 
victoria del segundo, sin perjuicio de que no tengan idéntica relación sustancial con el objeto material que se establezca por el fallo ${ }^{428}$.

Los coactivos son aquéllos que resultan del papel que ineludiblemente la ley impone a sus componentes ${ }^{429}$. Son: el necesario (art.91(89) segunda parte CPCCN) el forzoso que -excluidos los casos de litisconsorcio necesario- derivará de notificarse la demanda a varios demandados, situación que les fuerza a definir su posición frente al actor de modo que serán litisconsortes si deciden enfrentarlo; los litisconsorcios que llamamos de liberación y preferencia, que hacen a las tercerías de dominio y mejor derecho en los cuales, ante la demanda, los sujetos originarios tendrán que definir indefectiblemente si coinciden con el demandante o lo hacen entre ellos para enfrentarlo. Por fin el litisconsorcio obligado.

b) El litisconsorcio obligado. El litisconsorcio obligado es el que puede formarse como consecuencia de la litisdenuncia y citación prevista en el art.96(94) CPCCN, apuntado a los fines de nuestro estudio a la intervención obligada a la que calificamos como genérica. El tema impone que lo estudiemos según el método seguido hasta el momento.

c) Denuncias de litis regresivas y extensivas. Las denuncias regresivas y extensivas generarán un litisconsorcio obligado cuando el citado al presentarse al juicio, coincida con alguna de las partes originarias en enfrentar a la contraparte pero, manteniendo en ello su naturaleza tercerista. Ahora bien, la reacción del tercero genera situaciones singulares

\footnotetext{
${ }^{428}$ Rivas Adolfo A.Obra citadat.II,pg. 197

${ }^{429}$ Por ejemplo el litisconsorcio necesario integrado desde el vamos por todos los demandantes o cuando concurren previa citación judicial.
} 
que habrá que analizar según la clase de responsabilidad que se impute y de las que puede resultar una coincidencia final -el rechazo de la demanda- de carácter absoluto (fáctica y jurídica), o bien, igual coincidencia pero limitada, por estar sustentada en versiones fácticas distintas (por ejemplo el citante atribuye responsabilidad cuasidelictual al tercero y éste si bien se presenta para enfrentar al actor, lo hace asignando la culpa a otro tercero por quien el demandado no debe responder).

La mera diferencia o la misma contradicción argumental jurídica no impide que se conforme la asociación pues los sujetos no postulan sino un mismo resultado sobre la base de igual versión de los hechos. Cuando esto último no ocurre, se dará el fenómeno recordado por Calamandrei (coincidencia en un plano de la discusión y divergencia en otro) que a nuestro juicio no excluye la formación litisconsorcial en cuanto se confluya en sustentar la improcedencia de la demanda, siempre que ello no importe definir el juicio en favor de un componente pero en detrimento del otro.

d) Denuncias de litis excluyentes. Debe advertirse que la formación litisconsorcial que puede resultar de la citación obligada al tercero pretendiente habrá de darse fuera del campo de aplicación de los arts.96(94) y 98(96) del CPCCN y en el de la acumulación de litis. No obstante y por su relación con aquel origen, nos referiremos al tema. Ante el tercero devenido en accionante, las partes originarias podrán reacomodarse de distintas maneras y con ello quedará o no configurado un litisconsorcio, a saber:1) actor primitivo se allana ante el citado demandante y desaparece entonces toda posibilidad de actuación litisconsorcial pues el litigio sigue entre el reivindicante y el demandado primitivo. 2) demandado se allana, reconociendo la legitimación del tercero-demandante, aunque manteniendo su oposición a la pretensión de 
cobro. No hay litisconsorcio pues en lo relativo al primer tema, solamente queda el actor resistiendo al tercero-demandante y con respecto al segundo, la postura del demandado, es incompatible con la de ambos acreedores que a su vez mantienen posiciones opuestas entre sí. 3) actor y demandado, manteniendo su enfrentamiento primitivo, se unen litisconsorcialmente (litisconsorcio forzoso) para enfrentar al reivindicante. 


\section{Bibliografia}

Alcala Zamora y Castillo Niceto. Estudios de teoría general e historia del proceso(1945-1972)Universidad Autónoma de México.México.1992.

Allorio Enrico. La cosa giudicata rispetto ai terzi.Dott.A.Giufrré Editore.Milán.1925.

Alsina Hugo.“Intervención de terceros en la relación procesal-(J.A. t.71-Sec. Doctrina, pg.4).

Alsina Hugo.“Unificación de la legislación acerca de la intervención de terceros en la relación procesal (J.A.1957-IV-50 Sec.Doctrina)

Alsina Hugo.Tratado Teórico Práctico de Derecho Procesal Civil y Comercial, Segunda edición. Ediar. Buenos Aires. 1956.

Alvarado Velloso Adolfo. Introducción al estudio del Derecho Procesal, Segunda parte. Rubinzal-Culzoni.Santa Fe.1998.

Alvarez Urcisino. Curso de Derecho Romano. Revista de Derecho Privado.Madrid. 1955.

Alzamora Valdez Mario. Derecho Procesal Civil. Eddili .Octava edición. Lima.

Arazi Roland "El tercero adherente simple”,LL 1995-C-442

Arazi Roland -Rojas Jorge A. Código Procesal Civil y Comercial de la Nación,Comentado,anotado y concordado con los códigos provinciales T.I,pg.374.Rubinzal-Culzoni.Santa Fe.2001.

Arruda Alvim Manuel .Manual de Directo Processual Civil. 6aed.San Pablo.1997.

Baracat Edgar José. Intervención de terceros en la "inoponibilidad "concursal.Distintos supuestos.Ejecución de la sentencia contra el interventor. LL 2010-B-Sección Doctrina,pg 1001.

Barbato Nicolás Héctor. La citación en garantía del asegurador,E.D.T.150 pg.73. 
Bonfanti Mario Alberto-Garrone José Alberto. Concursos y quiebras, Tercera edición. Abeledo Perrot.

Borda Guillermo A.Tratado de Derecho Civil Argentino. Contratos .Novena edición. La Ley.Buenos Aires.2008.

Bremberg Axel,Intervención coactiva de terceros en el proceso.L.L.80-268

Calamandrei Piero. Instituciones de Derecho Procesal Civil. Según el Nuevo Código.Traducción de la primera edición italiana por Santiago Sentis Melendo. EJEA. Buenos Aires.1973 .

Calamandrei Piero.La Chiamate in garantía, pgs 85 a 94.Societá editrice Librería.Milano.1913.

Carnelutti Francesco. Instituciones del Proceso Civil. EJEA.Buenos Aires.1973. Traducción por Santiago Sentis Melendo de la quinta edición italiana editada por Foro Italiano. Roma.1965.

Carrión Lugo Jorge. Tratado de Derecho Procesal Civil, Segunda edición. Editora Jurídica Grijley. Lima. 2004.

Castro de, Manuel Antonio. Prontuario de práctica forense. Segunda edición. Imprenta Nacional Argentina. Bueno Aires, 1863 )

Chiovenda Giussepe. Principios de Derecho Procesal Civil, Traducción española de la Tercera edición italiana, por José Casais y Santaló, tomo II, .Editorial Instituto Editorial Reus. Madrid. 1941.

Código Procesal Civil de la Provincia de Jujuy.Ediciones Noroeste Argentino.Salta.2000.

Conde de la Cañada. Instituciones de los juicios civiles, así ordinarios como extraordinarios, en todos los trámites según que se empiezan, continúan y acaban en los tribunales reales. Observaciones prácticas sobre los recursos de fuerza; modo y forma de introducirlos, continuarlos y de terminarlos en los tribunales Superiores. T.1 pg 181 Tercera edición. Compañía General de Impresores y Libreros del Reino. Madrid. 1845. Primera edición 1794. 
Colombo Carlos J-Kiper Claudio M. Código Procesal Civil y Comercial de la Nación. Anotado y Comentado. Buenos Aires. 2006. 1978.

Colombo Carlos J. El proceso con pluralidad de partes y las figuras procesales que lo integran L.L.1986-D-425.

Colombo Carlos J. Evicción, Litis denuntiatio y Laudatio auctoris, en Revista de Derecho Procesal, Dirección Hugo Alsina, Año II, Primer trimestre 1944,nº 1.Ediar ,Buenos Aires, pg 29.

Colombo Juan Martín.Procesos administrativos con sujetos múltiples.El coadyuvante y los terceros en el proceso administrativo de la Provincia de Buenos Aires.Abeledo Perrot Buenos Aires.Julio 2009.nº7,pg737.

Couture Eduardo.Vocabulario Jurídico. $3^{\circ}$ ed.actualizada y ampliada por Angel Landoni Sosa.Ed.Bdef.Montevideo-Buenos Aires.2004)

Couture Eduardo J.Fundamentos de Derecho Procedsal Civil.Tercera edición (póstuma). Depalma .Buenos Aires.1958.

Dávila Milán Maria E..Litisconsorcio necesario.Concepto y trtmiento procesal.Boch.Barcelona.1975.

De Gregorio Lavié Julio A. Código Procesal Civil y Comercial de la Nación. Comentado. Doctrina. Jurisprudencia. Ediar. Buenos Aires. 1985.

Fairen Guillen Victor.Doctrina General del Derecho Procesal.Libreria Bosch.Barcelona.1990.

Espinosa de Benincasa Maria Cristina y Benincasa Juan Carlos. Problemática de la citación del tercero en el proceso civil. Su condena.LL 1992-B-791.

Falcón Enrique M. Derecho Procesal Civil y Comercial, Concursal, Laboral y Administrativo. Rubinzal-Culzoni. Buenos Aires-Santa Fe.2003.

Falcón Enrique M. Intervención de terceros, en Revista de Derecho Procesal 2006-2 pg.515.Rubinzal-Culzoni.Santa Fe.2006. 
Falcón Enrique M. Tratado de Derecho Procesal Civil y Comercial. Rubinzal-Culzoni. Buenos Aires.2006.

Falcón Enrique M. Código Procesal Civil y Comercial de la Nación. Comentado, concordado y Anotado. Lexis-Nexis.Abeledo-Perrot.Segunda edición.Buenos Aires.2006.

Falke Ignacio A.¿Acciones de clase o procesos de clase?.Pasado,presente y futuro de la creación.Boletín nº7.,pg 3.JA 2014-II.

Fassi Santiago C.-Yañez César D. Código Procesal Civil y Comercial. Comentado, anotado y concordado, Tercera edición. Astrea. Buenos Aires.1988.

Fenochietto Carlos Eduardo-Arazi Roland.Código Procesal Civil y Comercial de la Nación. Comentado y concordado. Segunda edición actualizada. Astrea. Buenos Aires.1993.

Febrero Novísimo o Librería de Jueces, Abogados, Escribanos y Medicos Legistas por don Eugenio de Tapia, .Nueva Edición. Librería de Lecointe. Paris 1845.

Feijó Claudio Ramón.”Oportunidad para el demandado de citar a un tercero en el proceso ordinario".L.L.1997-A-348.

Fernandez Raymundo L.Proyecto de Codigo Procesal Civil y Proyectos complementarios. Decreto 5818/58.Edición Oficial. Buenos Aires.1962.

Fernández Maza Guadalupe, La citación de evicción, en Intervención de terceros y tercerías, Director Osvaldo Alfredo Gozaini, .Rubinzal-Culzoni. Editores. Santa Fe Buenos Aires, 2011.

Fons Rodríguez Carolina.La acumulación objetiva de acciones en el proceso civil.Bosch.Barcelona.1998.

Fiorenza Alejandro Alberto.La intervención de terceros en el proceso civil santafecvino.E.D.254-864.

Giannini Leandro J. El alcance de la sentencia para terceros .A la Luz de la reforma del CPCN.L. L. 2002-F-1122. 
Goldschmidt James. Derecho Procesal Civil de, Traducción de la Segunda edición alemana y del Código Procesal Civil alemán, incluido en el apéndice por Leonardo Prieto Castro. Editorial Labor S.A. Barcelona-Madrid-Buenos Aires-Río de Janeiro. 1936.

Gomez Lara Cipriano.Derecho Procesal Civil.Sexta edición.Colección Textos Jurídicos Universitarios.México D.F.1991.

Gonzalez Atilio Carlos, Estudios de Derecho Procesal. Alcance de la sentencia frente a la citación provocada del tercero interviniente .Ad Hoc. Buenos Aires. Primera edición. 1990.

Gonzalez Atilio Carlos. La intervención voluntaria de terceros en el proceso.Abaco.Buenos Aires.1994.

Gozaini Osvaldo Alfredo.Comentarios a la ley 25.488 de reformas al Código Procesal Civil y Comercial de la Nación. ADLA LXI-E-6571.

Gozaini Osvaldo Alfredo. La legitimación en el proceso civil. Ediar. Buenos Aires.1996. Guarino Arias Aldo. Código Procesal Civil de Mendoza .Comentado, Anotado y Concordado. Ed.Jurídicas Cuyo. Mendoza.1983.

Guasp Jaime, Derecho Procesal Civil, Cuarta edición. Revisada y adaptada por Pedro Aragoneses, Civitas. Madrid. 1998.

Girard Maria. El alcance de la sentencia de condena hacia los terceros obligados. ED 257-694

Highton de Nolasco Elena I-Areán Beatriz A. Código Procesal Civil y Comercial de la Nación. Concordado con los códigos procesales provinciales. Análisis de Doctrina y Jurisprudencia. Elena H. Highton-Beatriz A. Areán. Directoras,T.2, Hammurabi. Buenos Aires. 2004.

Jofré Tomás, Manual de Procedimiento (Civil y Penal) Segunda edición. Valerio Abeledo. 1920. Buenos Aires.

Jofre'Tomas.Proyecto de Código de Procedimiento Civil.Imprenta de la Universidad.Buenos Aires.1926. 
Josserand Luis. Derecho Civil. Revisado y completado por André Brun, T.II Contratos. Trad.Cunchilles y Manterola. Revisada por Santiago Sentis Melendo. Bosch. Buenos Aires.1951.

Kisch.Elementos de Derecho Procesal Civil, Traducción de la cuarta edición alemana y adiciones de derecho español de L .Prieto Castro, Segunda Edición, Revista de Derecho Privado. Madrid. 1940.

Kenny Héctor Eduardo. La intervención obligada de terceros en el proceso civil. Depalma. Buenos Aires.1983.

Kielmanovich Jorge, Comentario sobre la ley 25.488 de reformas al Código Procesal Civil y Comercial de la Nación, ADLA LXI-E-6591.

Lafaille Héctor Curso de contratos. Compilado por Isauro P. Arguelles (h) y Pedro Frutos, T. II, Contratos bilaterales, Talleres gráficos Ariel. Buenos Aires.1928.

Llambias Jorge Joaquín. Tratado de Derecho Civil. Obligaciones.2 ${ }^{\mathrm{a}}$ edición.Editorial Perrot. Buenos Aires.1975.

Larrosa Amante Miguel Angel. Las partes problemática procesal. Consejo General del Poder Judicial. Cuadernos de Derecho Judicial XIX-2005.Madrid.

Legón Fernando A.Letra de cambio y pagaré. Tercera edición.LexisNexis. Abeledo Perrot. Buenos Aires.2006.

Leguisamón Héctor E. Una oportunidad perdida para condenar al tercero obligado en los accidentes de tránsito.L.L.1990-E-1008.

Leguizamón Héctor E. Una nueva oportunidad perdida para condenar al tercero obligado en los accidentes de tránsito.L.L.1993-E-752.

Leguisamón Héctor Eduardo. La intervención del tercero obligado y la ejecutabilidad de la sentencia a su respecto. Revista de Derecho Procesal 2006-2 pg.214.Rubinzal-Culzoni.Santa Fe.2006.

Leguisamón Hector Eduardo. La condena al tercero en la reforma de la ley 25.488.Necesidad de un nuevo fallo plenario. LL 2004-B-1313. 
Leible Stefan. Proceso Civil Alemán. Biblioteca Jurídica Dike. Konrad Adenauer Stiftung.Medellín. Colombia. 1999.

Liebman Enrico Tullio. Manuale di Diritto Processuale Civile. Ristampa inalterata Della seconda edizione. Dott.A.Guiffré Editore. Milano.1968.

López Fragoso Tomás.La intervención de terceros a instancia de parte en el proceso civil español. Marcial Pons Ed.Jurídicas .S.A. Madrid.1990.

Loreto Luis. La cita de saneamiento y de garantía (Esquema Magistral de la terceria) en De la terceria en el Derecho Procesal Civil. Doctrina. Legislación. Jurisprudencia. Segunda edición aumentada. Caracas. 1994

Llambias Jorge Joaquín, Tratado de Derecho Civil, Obligaciones. Segunda edición actualizada. Editorial Perrot.Buenos Aires.1973.

Martínez Hernán J.Procesos con sujetos múltiples,t.1,pgs 330 y 331. La Rocca. Buenos Aires. 1987.

Martínez Hernán J. Terceros. Necesidad de un adecuado encuadre jurídico .J.A.1993III-521).

Mattirolo Luis, Instituciones de Derecho Procesal Civil, Traducción de Eduardo Ovejero. Ed. La España Moderna. Madrid.

Meilij Gustavo Citación en garantía del asegurador, Revista Jurídica Argentina del Seguro, la Empresa y la Responsabilidad Civil,ns²1/22,pg 134.

Mercader Amilcar. El tercero en el proceso. Abeledo Perrot. Buenos Aires.1960.

Micheli Gian Antonio.Curso.Curso de Dereho Procesal Civil. EJEA. Buenos Aires,1970.Traducción de Santiago Sentis Melendo del primer volúmen de la obra Corso di Diritto Processuale Civile.Dott.A Giuffré.Milano.1959.

Meroi Andrea.Desequilibriosen la recepción de modelos de procesos colectivos.

Montero Aroca Juan.Ortells Ramos Manuel.Gómez Colomer Juan Luis. Derecho Jurisdiccional,t.II, $1^{\circ}$ (pg.56),Librería Bosch.Barcelona.1989. 
Montero Aroca Juan.La intervención adhesiva simple. Contribución al estudio de la pluralidad de partes en el proceso civil.Ed.Hispano Europea. Barcelona.

Montero Aroca Juan. Acumulación de proceso y proceso único con pluralidad de partes. Revista Argentina de Derecho Procesal n³.Julio-Septiembre 1972.pg.395. La Ley Buenos Aires.

Morales Molina Hernando. Curso de Derecho Procesal Civil. Décima edición.ABC.Bogota.1988.

Morello Augusto M. El tercero en el proceso ¿Un supuesto excepcional y de interpretación estricta? LL 2005-D-728.

Morello Augusto Mario. Sosa Gualberto Lucas. Berizonce. Roberto Omar Tessone Alberto. Manual de Código Procesal Civil y Comercial de la Provincia de Buenos Aires. Segunda edición. Librería Editora Platense. La Plata.1997.

Morello Augusto Mario. Gualberto Lucas Sosa. Roberto Omar Berizonce.

Códigos Procesales en lo Civil y Comercial de la Provincia de Buenos Aires Comentados y anotados. Segunda edición. Libreria Editora Platense-Abeledo Perrot. La Plata.1985.

Morello Augusto Mario. Panorama de la intervención de terceros y las tercerías en los nuevos códigos procesales de la Nación y de la Provincia de Buenos Aires. Revista Argentina de Derecho Procesal n².Abril-Junio 1969.La Ley .Buenos Aires.

Morello Augusto Mario. Cuando el tercero se convierte en parte (Una expansión inteligente de la garantía de la defensa E.D.177-87

Ostrower Ricardo A. y Soria Santiago. Reforma al Código Procesal Civil y Comercial de la Nación .Comentarios generales a la reforma. LL 2002-A-1079

Ossorio Manuel. Diccionario de Ciencias Jurídicas Políticas y Sociales. Ed.Heliasta. San Pablo. Brasil.

Palacio Lino E. Derecho Procesal Civil. Segunda edición actualizada por Carlos Enrique Camps. Abeledo Perrot. Buenos Aires 2011. 
Palacio Lino E. Anotaciones para una explicación de la reforma procesal civil y comercial (ley 25.488) L.L 2002-A-1178.

Palacio Lino E.Un caso anómalo de intervención de terceros. LL 199 7-C-500.

Pallares Eduardo .Derecho Procesal Civil .Editorial Porrua. México. 1961.

Parada Mendía Alex. El tercero en el proceso civil. IvrisTantvm. Santa Cruz de la Sierra.2009.

Parra Quijano Jairo. La intervención de terceros en el proceso civil. .Depalma. Buenos Aires.1986.

Podetti J Ramiro. Tratado de la tercería. Segunda edición actualizada por Victor A.Guerrero Leconte. Ediar. Buenos Aires. 1971.

Proto Pisani Andrea.Lizioni di Diritto Processuale Civile.Jovene Editore .Nápoli.1994.

Redenti Enrico .Derecho Procesal Civil. Traducción Santiago Sentis Melendo y Mariano Ayerra Redín. Milán. Dotto A Guiffré.1952.

Reimundin Ricardo. La reforma procesal civil en la Provincia de Salta. Salta.1948.

Reimundin Ricardo.La intervención de terceros en el proceso.Revista de Estudios Procesales nº4.pg.85.Centro de Estudios Procesales.Rosario.1970.

Rodríguez Luis A Rodríguez Saiach. Reformas al Código Civil y Comercial de la Nación.Ley 24.488 y concordantes.

Rojas Jorge A.La legitimación y los sistemas de acceso al proceso colectivo. Revista de Derecho Procesal .Rubinzal Culzoni.Buenos Aires-Santa Fe. 2011-Número extraordinario,pg. 133

Ripert George-Boulanger Jean, Tratado de Derecho Civil según el Tratado de Planiol, T.VIII, Contratos Civiles, La Ley, Buenos Aires.1965.

Rodríguez Alberto M. Comentarios al Código de Procedimientos en materia Civil y Comercial de la Capital de la República Argentina, Segunda edición. S.A.I.G. Barcelona Seix \& Barral Hermanos. Barcelona. 1914. 
Reus Emilio. Ley de Enjuiciamiento Civil del 3 de febrero de 1881. Concordada y anotada con gran extensión según la doctrina de los autores y la Jurisprudencia del Tribunal Supremo, por la Redacción de la Revista General de Legislación y Jurisprudencia, bajo la dirección de Emilio Reus, Segunda edición. Madrid. Hijos de Reus. Editores. 1909.

Rivas Adolfo Armando. Tratado de las tercerías.Abaco. Buenos Aires. 1996

Rivas Adolfo A.Teoría General del Derecho Procesal, pg .LexisNexis. Buenos Aires.2005.

Rocco Hugo. Tratado de Derecho Procesal Civil. Reimpresión inalterada, Temis(Bogotá)-Depalma.Buenos Aires. 1976. Traducción del Tratttato di diritto processuale civile por Santiago Sentis Melendo y Marino Ayerra Redín

Rosemberg Leo. Tratado de Derecho Procesal Civil. Tomo I, pgs 278 a 283.EJEA.BuenosAires.1955.Traducción de Angela Romera Vera de la Quinta edición alemana de la obra "Llehrbuch des deutschen Zivilprozesssrechts".C.H.Beck'sche Verlasbuchhandlung.München und Berlin.1951.

Stiglitz Rubén S.- Stiglitz Gabriel A. Contrato de seguro. Ediciones La Rocca. Buenos Aires. 1988.

Safi Leandro. Litisconsorcio y procesos colectivos. Revista de Derecho Procesal. Rubinzal Culzoni.Buenos Aires-Santa Fe. 2011-Número extraordinario,pg.179

Sajón Jaime. Concursos. Ley 19.551. Abeledo Perrot. Buenos Aires.1974.

Salvat Raymundo M. Tratado de Derecho Civil Argentino, Fuente de las Obligaciones. Actualizada por Arturo Acuña Anzorena, TEA, Segunda Edición. Buenos Aires.1954.

Samanes Ara Carmen. Las partes en el proceso civil.La Ley. Madrid .2000.

Satta Salvatore. Manual de Derecho Procesal Civil. traducción de Santiago Sentis Melendo y Fernando de la Rúa de la Séptima edición de Diritto Processuale Civile.CEDAM.Dott.Antonio Milani Milano.Padova. 1967. EJEA. Buenos Aires. 1971.

Schönke Adolfo. Derecho Procesal. Bosch.Barcelona.1950.

Serra Domínguez Manuel. Estudios de Derecho Procesal. Ediciones Ariel. Barcelona.1969.. 
Simone Blas. Autonomía y caracteres de la citación en garantía del asegurador en los seguros de responsabilidad civil.L.L.1975-D-p.11.

Véscovi Enrique. Director. Código General del Proceso Ed.Abaco. Montevideo.1993.

Vicente y Caravantes José de, Tratado Histórico, Critico Filosófico de los Procedimientos Judiciales en Materia Civil según la nueva Ley de Enjuiciamiento. Imprenta de Gaspar y Roig Editores. Madrid. 1856.

Viel Temperley Facundo.Discrecionalidad de los jueces cuando hay cosa juzgada.LL 2009-F-610.

Wach Adolf.Manual de Derecho Procesal Civil.(Traducción del alemán de la obra Handuch des Deustchen Civil Prozessrechts,I,Leipsig.1885).por Tomás A.Banzhaf. .EJEA.Buenos Aires.

Wayar Ernesto Clemente, La garantía de evicción, E.D.104-859

Wetzler Malbrán Ricardo. Ejecutabilidad de la sentencia contra terceros en los casos de intervención obligada ED 111-895.

Wetzler Malbrán Ricardo. Definición a nivel plenario de los efectos de la sentencia de condena respecto del tercero citado a juicio, ED 132-815,

Wetzler Malbrán Ricardo. Nuevamente sobre la problemática de la posibilidad de condena contra el tercero a pedido de la demandada originaria ED 188-356.

Adolfo Armando Rivas

Abril 2015 